
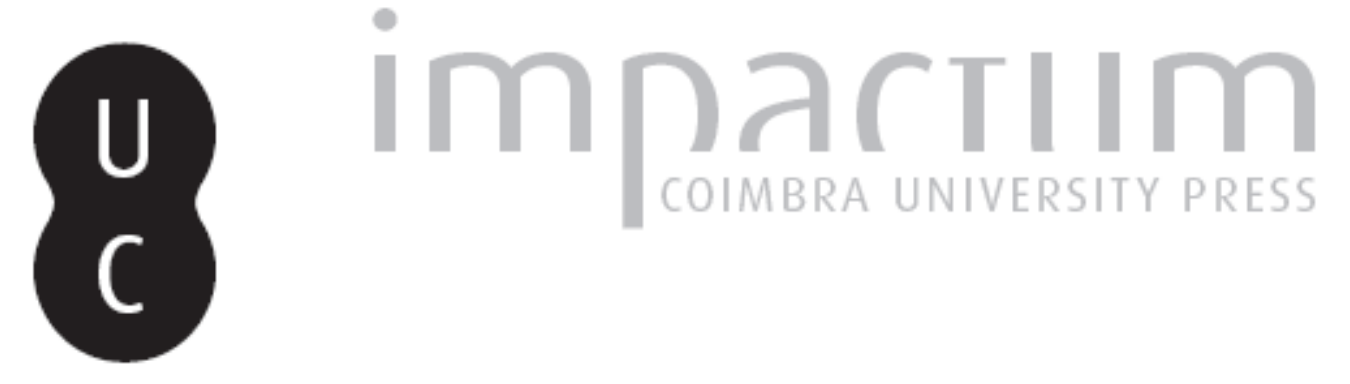

\title{
Do Belo como constituinte do humano segundo Sócrates/Diotima
}

\section{Autor(es): $\quad$ Carvalho, M. Jorge de}
Publicado por: Faculdade de Letras da Universidade de Coimbra, Instituto de Estudos Filosóficos

$\begin{array}{ll}\text { URL } & \text { URI:http://hdl.handle.net/10316.2/33297 } \\ \text { DOI: } & \text { DOI:http://dx.doi.org/10.14195/0872-0851_38_6 }\end{array}$

Accessed : $\quad$ 26-Apr-2023 10:33:37

A navegação consulta e descarregamento dos títulos inseridos nas Bibliotecas Digitais UC Digitalis, UC Pombalina e UC Impactum, pressupõem a aceitação plena e sem reservas dos Termos e Condições de Uso destas Bibliotecas Digitais, disponíveis em https://digitalis.uc.pt/pt-pt/termos.

Conforme exposto nos referidos Termos e Condições de Uso, o descarregamento de títulos de acesso restrito requer uma licença válida de autorização devendo o utilizador aceder ao(s) documento(s) a partir de um endereço de IP da instituição detentora da supramencionada licença.

Ao utilizador é apenas permitido o descarregamento para uso pessoal, pelo que o emprego do(s) título(s) descarregado(s) para outro fim, designadamente comercial, carece de autorização do respetivo autor ou editor da obra.

Na medida em que todas as obras da UC Digitalis se encontram protegidas pelo Código do Direito de Autor e Direitos Conexos e demais legislação aplicável, toda a cópia, parcial ou total, deste documento, nos casos em que é legalmente admitida, deverá conter ou fazer-se acompanhar por este aviso.

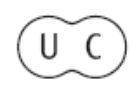




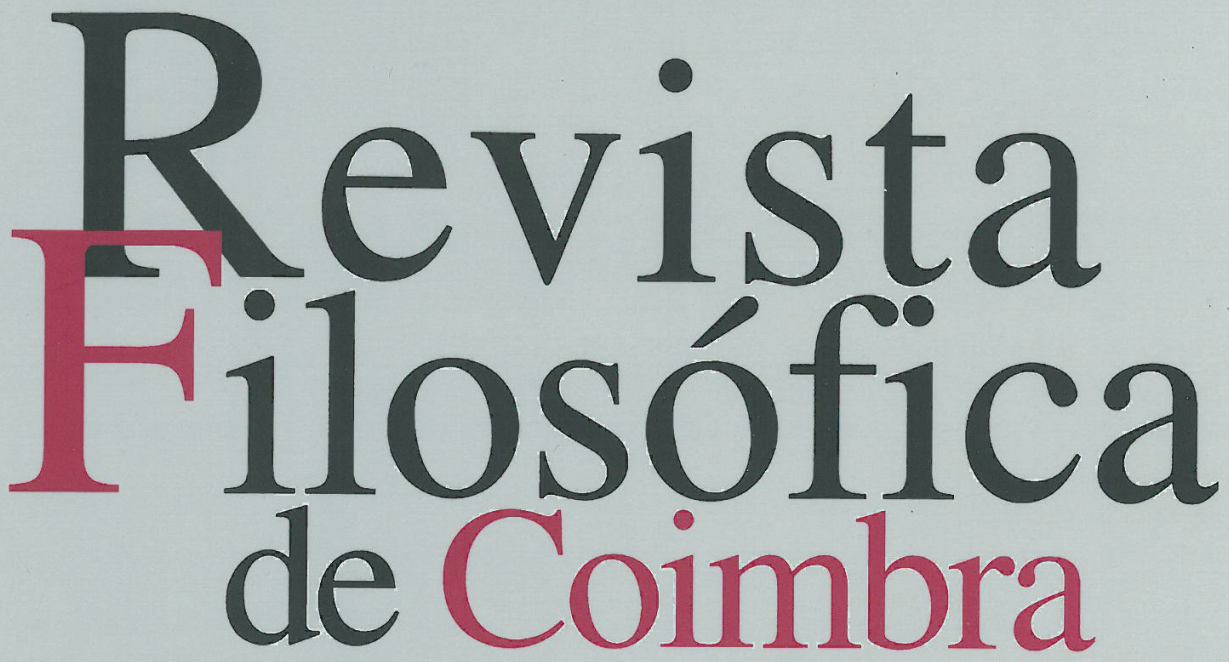

vol.19|n.038|2010

Mário Santiago de Carvalho Fernanda Bernardo Mário Jorge de Carvalho Michael Marder Marco Lamanna João Carlos Brum Torres Gonçalo Marcelo Marisa das Neves Henriques 


\title{
DO BELO COMO CONSTITUINTE DO HUMANO SEGUNDO SÓCRATES/DIOTIMA
}

\author{
M. JORGE DE CARVALHO*
}

\section{Introdução. O discurso de Agatão e a reacção de Sócrates}

Muitas vezes não se pode começar pelo princípio - e esta é uma delas. Entre outras razões, porque não cabe acompanhar o Symposium desde o começo. Com efeito, pretendemos focar um aspecto fundamental do discurso de Sócrates/Diotima - mais propriamente, um aspecto fundamental daquilo que o discurso de Sócrates/ Diotima diz sobre o Belo. ${ }^{1}$ Ora, esse aspecto tem que ver com uma reacção ou resposta às intervenções anteriormente produzidas no Symposium, que, todavia, não podemos seguir num breve esboço como aquele que aqui se apresenta. Por isso, temos de entrar, se assim se pode dizer, "já a meio do filme". E daí resulta uma certa limitação de ângulo, que também não nos permite acompanhar o próprio discurso de Sócrates/Diotima em todo o seu significado e implicações.

${ }^{*}$ Universidade Nova de Lisboa; L.I.F. - Universidade de Coimbra.

${ }^{1}$ Falamos de Sócrates/Diotima porque, embora haja uma parte da intervenção de Sócrates que precede propriamente o relato do que foi dito por Diotima, Sócrates afirma que o seu diálogo com Agatão repete um outro que ele mesmo teve com Diotima uns anos atrás - cf.

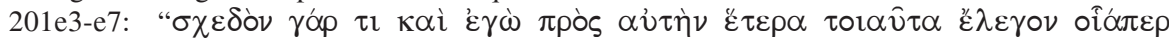

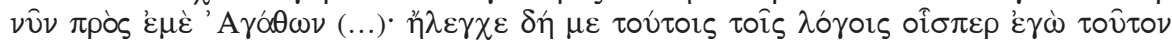
(...)". Assim, toda a intervenção de Sócrates é apresentada como tomada de Diotima: outra vez as palavras de Diotima, agora subscritas por Sócrates - como se houvesse dois diálogos/ discursos de conteúdo sensivelmente igual, um que terá tido lugar entre Sócrates e Diotima, no passado, e o outro no "tempo real" do Symposium, com Sócrates a tomar o lugar de Diotima e a pôr Agatão (e, com ele, os restantes convivas e o leitor) na posição que foi a sua uns anos antes. Não discutimos aqui o significado da figura de Diotima e desta peculiar transferência de autoria que assim marca, do princípio ao fim, a intervenção de Sócrates. Tampouco podemos analisar neste quadro a figura de qualquer coisa como um Sócrates imaturo, que surge neste passo do Symposium e noutros textos do corpus platonicum. Esta figura aparece tanto na forma de um Sócrates jovem (o próprio Sócrates, ainda "verde", como aqui ou no Parmenides) quanto na de outras personagens cuja parecença com Sócrates é cuidadosamente vincada, mas 
Mas, tendo de começar por algum lado (e de preferência por um ponto de partida que não nos obrigue a um percurso muito longo), partimos do discurso de Agatão ou melhor, de alguns aspectos decisivos do discurso de Agatão, que desencadeiam a reacção de Sócrates e, ao mesmo tempo, também podem servir de meio de contraste para melhor perceber o que há de próprio na perspectiva que este último desenha.

Quanto ao discurso de Agatão, abstraímos das suas propriedades retóricas, de tudo aquilo que inegavelmente tem de artificial, dos seus traços caricaturais, etc. Interessam-nos, em particular, duas características fundamentais da sua descrição de

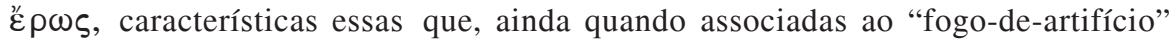
retórico do discurso, não se reduzem a uma mera expressão dele, antes reflectem concepções de fundo ou fenómenos relevantes ${ }^{2}$.

A primeira característica tem que ver com uma particularidade muitas vezes inatendida do conceito antigo de ع̌p Agatão. Na maioria dos textos, quando está ligado àquilo a que chamamos

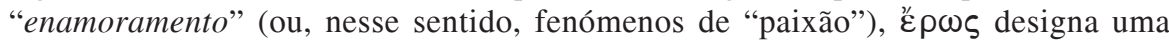

de tal modo que ainda se revelam pouco expeditas na análise dos problemas, ainda se perdem

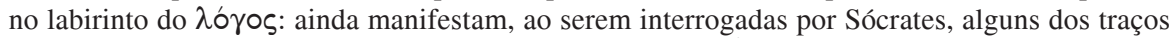
habituais dos seus interlocutores no corpus platonicum. É o que sucede, por exemplo, com Teeteto no diálogo a que dá o nome. Esta figura daquilo a que podemos chamar um Sócrates imaturo (ou, como também podemos dizer, a figura do Sócrates-ainda-a-caminho-de-si) parece destinada a vincar que Sócrates não constitui uma excepção (nascida já pronta e acabada, como Atena da cabeça de Zeus) mas sim uma possibilidade interna de cada um, susceptível de ser despertada em qualquer caso - quer dizer: susceptível de ser desenvolvida a partir da posição onde habitualmente se encontram os seus interlocutores, por desencadeamento de diálogos socráticos (que tanto podem ser provocados por outrem, quanto promovidos internamente por cada um). Quanto ao caminho que seguimos, importa advertir que, para ganharmos a pista da peculiar perspectiva que o discurso de Sócrates/Diotima desenha em relação ao Belo como constituinte do Humano, focamos, primeiro, aqueles elementos que são indispensáveis para uma compreensão global da concepção do Humano como $\mu \varepsilon \tau \alpha \xi u ́ v$ (que é a categoria fundamental do discurso), para, depois, considerarmos em especial aquela forma de $\mu \varepsilon \tau \alpha \xi v$ que tem que ver com o Belo e faz que também ele seja um constituinte - e um constituinte fundamental daquilo que nós somos.

${ }^{2}$ Há que vincar o carácter muito restrito daquilo que aqui cabe dizer sobre o discurso de Agatão. Não se pode fazer jus à complexidade de que se reveste a intervenção de Agatão, nem atender a todos os aspectos que teriam de ser considerados por uma análise detida do seu discurso. O brevíssimo bosquejo que aqui se apresenta não faz mais do que focar alguns aspectos especialmente relevantes para se poder entender o ponto de partida da intervenção de Sócrates/Diotima. Aliás, também no que diz respeito a esta última, não se trata aqui de levar a cabo uma análise integral da sua composição e estrutura, de cada uma das suas diferentes partes e da respectiva articulação, de todas as pistas que abre e de todas as perspectivas que desenha, de todos os conceitos que introduz, das diferentes possibilidades da sua interpretação, etc. Trata-se de algo muito mais circunscrito. Trata-se apenas de tentar pôr em evidência como nas palavras de Sócrates/Diotima - entre outras coisas que se deixam totalmente fora de consideração ou que só muito fugidiamente se consideram - aparece nitidamente apontado o Belo como constituinte do humano. 
força ou um poder que vem de fora, violento, irresistível - uma força ou um poder que irrompe, conquista, subjuga, toma posse e aprisiona com o seu sortilégio ${ }^{3}$. O que há a vincar aqui é este carácter exterior. Essa força ou esse poder tem a sua sede noutro ente de onde emana e é a partir dele que exerce o seu fascínio sobre quem fica à mercê dela. De sorte que o desejo que um outro ente sente em relação a essa fonte de fascínio é o resultado do fascínio que ela exerce a partir de fora ou do maravilhoso poder que parte dela. Por outras palavras, aquilo que, neste caso, é concebido como ع̋ $\rho \omega \varsigma$ tem o carácter de qualquer coisa como uma concentração ou fonte exterior de encanto, um foco de atracção, algo de maravilhoso que chama a si e constitui em torno de si qualquer coisa como um vortex, em que precipita quem o vê. E tudo aquilo que se passa noutro ente que não a própria fonte desse encanto e que tem que ver com ह̌p um ser invadido e tomado de assalto por esse encanto que vem de fora - um ser

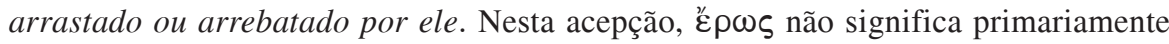
o desejo, a atracção que alguém sente, mas sim algo que se encontra ou se descobre: o próprio encanto ou a força do encanto enquanto tal - esse algo de extraordinariamente fascinante que tem a sua sede noutro ser humano e impõe de tal forma a sua presença, a partir dessa sede, que conquista e subjuga a partir dela. Em suma, trata-se do que se pode descrever como uma força ou um poder exterior. O lugar original e próprio de ép $\omega_{\varsigma}$ é algures aí fora (no estranho, incrível e inquietante "aî́" daquilo que parece absolutamente belo). Faz parte essencial de ع̌ $p \omega \varsigma$ esta radicação na alteridade, este carácter gritantemente alheio, esta pertença a outrem, que deixa justamente na impossibilidade de se continuar a ser sossegadamente aquilo que se é e faz que se corra em direcção a esse "aî", exterior, sem o qual não se pode nem se quer passar e que parece converter-se como que no centro absoluto de tudo. E ह̌ $p \omega \varsigma$ vem de fora, como chamamento e invasão que prende a essa presença

${ }^{3}$ Para prevenir mal-entendidos, importa vincar bem que estamos a falar do uso da palavra ¿̌pws quando refere algo de correspondente ao que nós designamos como o amor ou a paixão. Mas $\varepsilon^{\prime} \rho \omega \varsigma$, $\dot{\varepsilon} \rho \hat{\nu} \nu$, etc. são usados pelos antigos para designar diversos fenómenos muito diferentes deste - e, na verdade, para exprimir toda a espécie de formas de desejo dos mais

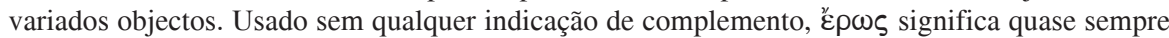
aquilo que está em causa quando falamos de paixão. Nos outros casos, aparece determinado pela indicação de um objecto, que pode ser - como se disse - da mais diversa ordem. Ora, quando tem por objecto a comida, a bebida, o sono, o descanso, o prazer sexual, a dança, a própria guerra, etc., etc., ع̌ $\rho \omega \varsigma$ aparece compreendido e expresso como algo de ínsito na própria constituição de quem o sente: como uma necessidade sua, que se manifesta com frequência variável - mas, seja como for, de tal modo que nasce de quem o sente, vem dele e o objecto desejado ganha relevância precisamente por força desta necessidade (desta carência ou precisão) própria, intrínseca, de quem tem desejo dele. Por outras palavras, o objecto desejado só ganha protagonismo em virtude do próprio desejo - e a sua importância vem da forma como permite satisfazer esse desejo (ou seja, da forma como permite que quem está "apertado" pelo desejo se veja livre dele e da inquietação que traz consigo - que é o que se

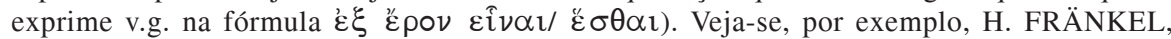
Dichtung und Philosophie des frühen Griechentums, München, Beck, 1962, 3. a ed. corr. 1976, 
exterior - como uma espécie de potência militar ou mágica ${ }^{4}$ a que não se consegue resistir, que invade, arrebata, leva de vencida, conquista, sem deixar escapar nada da sua presa ${ }^{5}$. Razão pela qual a palavra " $" \rho \omega \varsigma$ " é, em muitos textos da cultura grega antiga, difícil de traduzir e aparece deficientemente traduzida. Pois "amor", "paixão", "enamoramento" (ou o que quer que seja desta ordem) exprimem sobretudo o desejo que se sente - ou, de todo o modo, aquilo que se passa em quem está apaixonado:

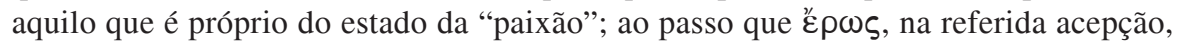
significa antes do mais aquilo que tem encanto (ou o próprio poder do encanto que isso encerra, o próprio encanto enquanto tal) e está associado a uma concepção para a qual o desejo sentido por outro ente não é mais do que um efeito ou resultado dessa força "objectiva" - uma extensão ou propagação do seu "império"6.

31, nota 8, F. LASSERRE, La figure d'Éros dans la poésie grecque, Lausanne, Imprimeries réunies, 1946, 21ss., J. LATACZ, Zum Wortfeld "Freude" in der Sprache Homers, Heidelberg, Winter, 1966, 179, 188, H. M. MÜLLER, Erotische Motive in der griechischen Dichtung bis auf Euripides, Hamburg, H. Buske, 1980, 14, G. KLOSS, Untersuchungen zum Wortfeld "Verlangen/ Begehren" im frühgriechischen Epos, Göttingen, Vandenhoeck \& Ruprecht, 1994, 24-34, 60-61, M. J. de CARVALHO, Die Aristophanesrede in Platons Symposium. Die Verfassung des Selbst, Würzburg, Königshausen \& Neumann, 2009, 387ss. No caso da paixão, porém, a óptica parece ser exactamente a inversa. E "ع̌ desejo, ínsito em quem o experimenta, que empresta protagonismo ao seu objecto - é o próprio objecto que se impõe de tal modo que produz desejo a seu respeito e invade alguém com esse desejo, prendendo-o a ele, convertendo-o num joguete dele, etc.

${ }^{4}$ Como podemos dizer, retomando as formas de descrição a que recorriam os antigos.

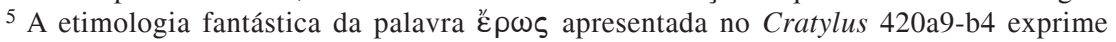

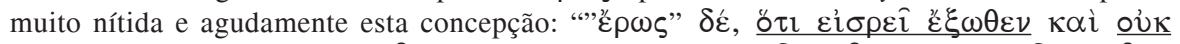

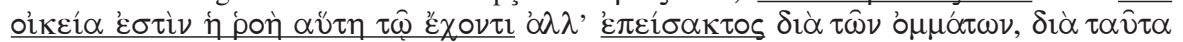

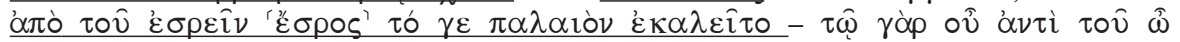

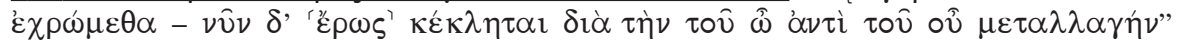

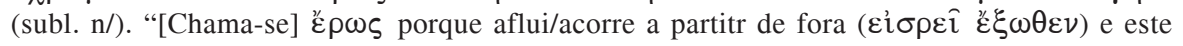
fluxo/corrente (

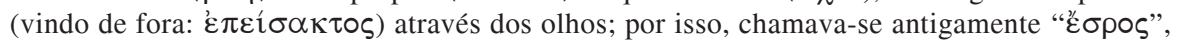
("influxo"), pois usávamos o "o" em vez do "ô", ao passo que agora se chama है $\rho \omega \varsigma$, por modificação do "o" em "ô"”. A este respeito, veja-se também Phaedrus 251b, 255c e, por exemplo, A. C. PEARSON, Phrixus and Demodice. A Note on Pindar, Pyth. IV, 162f., The Classical Review 23 (1909), 255-257, em especial 256s., L. MALTEN, Die Sprache des menschlichen Antlitzes im frühen Griechentum, Berlin, de Gruyter, 1961, H. DÖRRIE, Emanation: Ein unphilosophisches Wort im spätantiken Denken, in: K. FLASCH (ed.), Parusia: Studien zur Philosophie Platons und zur Problemgeschichte des Platonismus. Festgabe für J. Hirschberger, Frankfurt a. M., Minerva, 1965, 119-141, em especial 129, H. M. MÜLLER, Erotische Motive in der griechischen Dichtung bis auf Euripides, op. cit, 29ss., 213, S. DURUP L'espressione tragica del desiderio amoroso, op. cit., I. RIZZINI, L'occhio parlante. Per una semiotica dello sguardo nel mondo antico, Venezia, Istituto Veneto di Scienze, Lettere ed Arti, 1998 (Memorie, Classe di scienze morali, lettere ed arti, LXXVII), 119ss., M. L. GATTI, Etimologia e filosofia. Strategie communicative del filosofo nel "Cratilo" di Platone, Milano, Vita e Pensiero, 2006, 431s.

${ }^{6}$ A tradução por palavras como "amor", "desejo", etc. sugere de certo modo uma

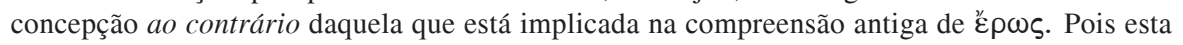




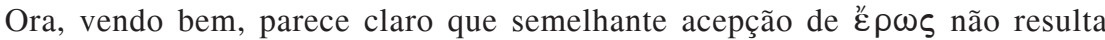
apenas de uma particularidade da língua grega ou das concepções desenvolvidas pelos antigos. De facto, traduz fenómenos e reflecte justamente a própria experiência do enamoramento ou da paixão. Pois, aos seus próprios olhos, o enamoramento é desencadeado pelo aparecer de um certo ente com propriedades excepcionais, que impõe a sua presença, sobrepondo-se a tudo o mais e eclipsando-o, pondo-se no centro de tudo. Aos seus próprios olhos, o enamoramento parece provocado por esse

aponta para uma peculiar realidade com sede no exterior e que, a partir do exterior, assalta um ser humano, invadindo-o, arrastando-o consigo, dominando-o por completo, "anexando-o"; ao passo que a ideia de "amor", "desejo", etc. sugere algo radicado em quem o sente, nascido e desenvolvido nele e a partir dele. Para evitar equívocos, convém, de todo o modo, ter presente que a antiga compreensão de ع̌ $\rho \omega \varsigma$ como força exterior não deixa de considerar também aquilo que alguém enamorado sente: o desejo, etc. Acontece apenas que concebe tudo isso não como algo radicado no próprio sujeito que se apaixona, mas sim como algo resultante da invasão e do poder da força exterior que o conquista, de tal modo que não é outra coisa

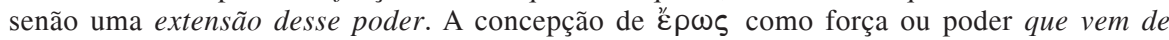
fora tem sido muito justamente posta em evidência na investigação contemporânea. Veja-se, por exemplo: A. C. PEARSON (ed.), The Fragments of Sophocles, Cambridge, University Press, 1917, 3 vols., ad Fr. 157, 474, 874, 932, 941, R. PFEIFFER, Gottheit und Individuum in der frühgriechischen Lyrik, Philologus 84 (1929), 137-152, 144ss. (=IDEM, Ausgewählte Schriften. Aufsätze und Vorträge zur griechischen Dichtung und zum Humanismus, ed. W. Bühler, München, Beck, 1960, 42-54, em especial 48s.), F. LASSERRE, La figure d'Éros dans la poésie grecque, Lausanne, Imprimeries réunies, 1946, 21ss., F. SOLMSEN, Hesiod and Aeschylus, Ithaca (NY), Cornell University Press, 1949, 83, 110, E. R. DODDS, The Greeks and the Irrational, Berkeley/London, University of California Press, 1951, 41, H. FRÄNKEL, Dichtung und Philosophie des frühen Griechentums. Eine Geschichte der griechischen Epik, Lyrik und Prosa bis zur Mitte des fünften Jahrhunderts, München, Beck, 1962, 3. ${ }^{a}$ ed., rev., 1976, 323s., G. MÜLLER, Sophokles. Antigone, Heidelberg, Winter, 1967, ad 781-800 (p. 171ss., 176ss., em especial 178), A. A. LONG, Language and Thought in Sophocles. A Study of Abstract Nouns and Poetic Technique, London, Athlone Press, 1968, 127s., E. FISCHER, Amor und Eros. Eine Untersuchung des Wortfeldes "Liebe" im Lateinischen und Griechischen, Hildesheim, Gerstenberg, 1973, 49ss., B. VICKERS, Towards Greek Tragedy: Drama, Myth, Society, London, Longman, 1973, 537, K. DOVER, Classical Greek Attitudes to Sexual Behavior, Arethusa 6 (1973), 59-74, 59s., IDEM, Greek Popular Morality in the Time of Plato and Aristotle, Berkeley/L.A., University of California Press, 1974, 208, B. SNELL, Das Erwachen der Persönlichkeit in der frühgriechischen Lyrik, in: IDEM, Die Entdeckung des Geistes. Studien zur Entstehung des europäischen Denkens bei den Griechen, Göttingen, Vandenhoeck \& Ruprecht, 1975, 4. ${ }^{a}$ ed. refund., 56-81, em especial 63ss., S. FASCE, Eros. La Figura e il culto, Genova, Istituto di Filologia Classica e Medievale, 1977, 10ss., 130ss., 144ss., 165ss., H. M. MÜLLER, Erotische Motive in der griechischen Dichtung bis auf Euripides, Hamburg, H. Buske, 1980, 7s., 17, 19ss., 27, 33ss., 41ss., 83s., M. DAVIES, The Eyes of Love and the Hunting-net in Ibycus 287 P., Maia 32 (1980), 255-257, A. CARSON, Eros. The Bittersweet. An Essay, Princeton (NJ), Princeton University Press, 1986, 4, 30, 44s., 148, 152s., G. CASERTANO, L'amour entre logos et pathos. Quelques considérations sur l'Hélène de Gorgias, in: B. CASSIN (ed.), Positions de la sophistique. Colloque de Cerisy, Paris, Vrin, 1986, 211-220, em especial 219s., W. SCHMID, Die Geburt der Philosophie im Garten der Lüste. M. Foucaults Archäologie des platonischen Eros, Frankfurt a. M., Athenäum, 1987, reed.: Frankfurt a. M., Fischer, 1994, 73-75, C. CALAME (ed.), L'amore in Grecia, 
ente (ou pelas suas propriedades de excepção) e sente-se sujeito ao extraordinário poder de atracção que ele exerce. Ou seja, o enamoramento só tem olhos para o seu objecto, está totalmente polarizado pelo protagonismo dele, vê-o como responsável por tudo o que sente, quer dizer pela total invasão que não deixa lugar senão para a relação com o próprio encanto e a sua fonte. Em suma, na singular acepção aqui em causa, a palavra " $\varepsilon \omega \varsigma$ " exprime justamente o modo característico como o enamoramento percebe a sua própria natureza, a sua origem e o seu objecto ${ }^{7}$.

Roma/Bari, Laterza, 1988, XXIXs., S. DURUP, L'espressione tragica del desiderio amoroso, ibi, 143-157, G. PICHT, Platons Dialoge Nomoi und Symposion, Stuttgart, Klett-Cotta, 1990, 420ss., R. PADEL, In and Out of the Mind. Greek Images of the Tragic Self, Princeton (New Jersey), Princeton University Press, 1992, 110ss., 114ss., 125ss., C. CALAME, I Greci e l'eros. Simboli, Pratiche e Luoghi, Roma/Bari, Laterza, 1992, 167, 175, H. PARRY, Thelxis. Magic and Imagination in Greek Myth and Poetry, Lanham (Md), University Press of America, 1992, 263ss., G. KLOSS, Untersuchungen zum Wortfeld "Verlangen/Begehren" im frühgriechischen Epos, Göttingen, Vandenhoeck \& Ruprecht, 1994, 34ss., 78, J. HOLZHAUSEN, Eros and Aidos in Phaidra's Monolog (Akademie der Wissenschaften und der Literatur Mainz. Abhandlungen der geistes- und sozialwiss. Klasse, 1995 1), Stuttgart, Steiner, 1995, 32, M. S. CYRINO, In Pandora's Jar. Lovesickness in Early Greek Poetry, Lanham (Md), University Press of America, 1995, 3ss., 8s., 46, 50, 63s., 91s., 101ss., 106s., 110, 114, 117, 136, 152s., B. GENTILI, Poesia e pubblico nella Grecia antica. Da Omero al V secolo, Bari, Laterza, 1995, 5. ed. aum., 59, 137, 149ss., A. NIGHTINGALE, Genres in Dialogue. Plato and the Construct of Philosophy, Cambridge, University Press, 1995, 158ss., S. THORNTON, Eros. The Myth of Ancient Greek Sexuality, Boulder (Col.), Westview Press, 1997, 14ss., 35ss., I. RIZZINI, L'occhio parlante. Per una semiotica dello sguardo nel mondo antico, Venezia, Istituto Veneto di Scienze, Lettere ed Arti, 1998 (Memorie, Classe di scienze morali, lettere ed arti, LXXVII), 116ss., 144ss., M. WEISS, Erotica: On the Prehistory of Greek Desire, Harvard Studies in Classical Philology 98 (1998), 31-61, M. W. SCHULLER, Watching the Self: The Mirror of Self-Knowledge in Ancient Literature, Diss. Yale University, 1998, 51ss. Para outros termos cujo campo semântico apresenta uma estrutura semelhante e para uma análise detida dessa estrutura, veja-se J. GROBER, Über einige abstrakte Begriffe des frühen Griechischen. Meisenheim a. Glan, A. Hain, 1963. Para uma análise mais circunstanciada dos aspectos que

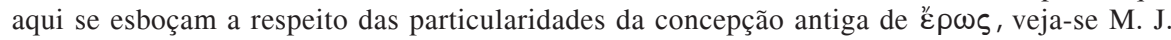
de CARVALHO, Die Aristophanesrede in Platons Symposium, op. cit.,387ss.

7 Há um ponto que importa assinalar aqui a respeito do nexo entre o que são particularidades da língua e da cultura gregas antigas e o que são fenómenos próprios do enamoramento ou da paixão enquanto tais. Os aspectos postos em evidência por Grober, no

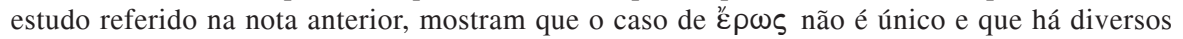
fenómenos que nós tendemos a entender como "sentimentos", com um carácter "subjectivo", etc., mas que na língua e na cultura gregas antigas, em particular no período arcaico, são concebidos como forças exteriores, etc. Tratar-se-á, então, de uma forma de compreensão característica da cultura grega antiga (e, na verdade, também de outras), mas que, pelo menos em grande parte, nos será estranha a nós. Não cabe discutir aqui este aspecto. Mas também não é indispensável fazê-lo, uma vez que, seja como for, nada disso invalida o que dissemos. Pois, vendo bem, independentemente da forma como se expresse (e chegue ou não a ter uma consciência explícita do modo como concebe as coisas), o olhar apaixonado tem características tais que por sua própria natureza segue sempre a óptica "objectivante" e se vive a si mesmo como inevitável efeito da descoberta de algo que lhe aparece como morada e fonte de um absoluto encanto, que o invade e leva de vencida, etc. Ou seja, para o olhar apaixonado a paixão 


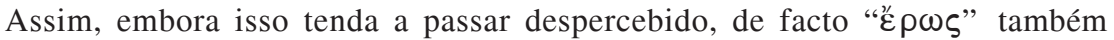
constitui uma designação para aquilo a que costumamos chamar "o belo" - mais precisamente para o belo enquanto invade e sujeita a si, numa completa ocupação do horizonte, tal que não deixa lugar para mais nada ou reduz tudo a uma posição de figurante, eclipsada pela sua presença única, excepcional e obsidiante. Quer dizer,

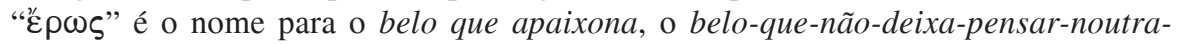
-coisa, o belo potência-exterior-que-invade-e-subjuga, etc. ${ }^{8}$.

Ora, é algo como esta potência exógena, esta presença ou esta fonte de invasão de encanto, que está em causa no discurso de Agatão - ou seja, é assim que Agatão entende ع̌p

Por outro lado, se não tivermos presente este primeiro aspecto, dificilmente poderemos compreender bem a segunda característica do discurso de Agatão que aqui nos interessa, porque é indispensável para entender o ponto de partida da intervenção de Sócrates: o carácter hiperbólico daquilo que Agatão diz. O discurso de Agatão cumula $̌$ č $\omega \varsigma$ de toda a espécie de predicados positivos. Não se trata apenas de « $\rho \omega \varsigma$ possuir a extraordinária força ou o extraordinário poder que já levava a tradição

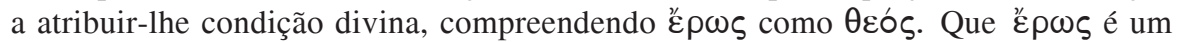
$\theta \varepsilon o ́ \varsigma$ - isso está suposto no discurso de Agatão, que põe na sua base justamente esta categoria mítico-religiosa. Mas, para além disso, Agatão apresenta ع̌ $\rho \omega \varsigma$, por assim dizer, como um "concentrado", cúmulo ou "totalista" de tudo quanto é

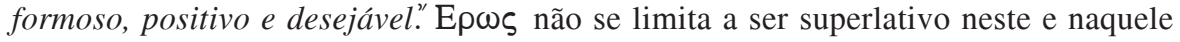
aspecto (como se noutros não fosse assim tão extraordinário ou até comportasse

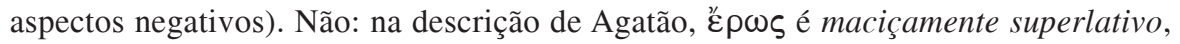
reúne toda a espécie de superlativos - é, se assim se pode dizer (parodiando um pouco os jogos de linguagem usados por Agatão), superlativamente superlativo. É claro que este pendor hiperbólico (ou "hiperbolicamente hiperbólico"), que faz da intervenção de Agatão uma espécie de "festival" do superlativo positivo, tem que

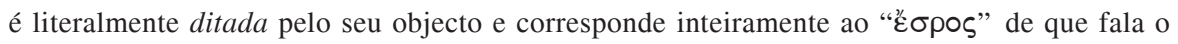
Cratylus. Para outros pontos de vista sobre a paixão pode não ser nada assim (e a paixão presta--se muito bem a ser entendida como um desenvolvimento idiossincrático de quem o sente - tão idiossincrático e produzido apenas por ele mesmo que até consegue descobrir encanto (mais: um encanto avassalador) onde ninguém mais enxerga nem remota sombra de algo desse género). Mas, para o próprio olhar apaixonado, a paixão é imposta do exterior: vem, para dizer como o poeta, da "coisa amada" e é uma consequência natural e inevitável do único, do extraordinário, do incrível, do maravilhoso que o objecto da paixão (que, ao mesmo tempo, aparece como fonte dela) encerra em si.

${ }^{8}$ Não é demais insistir neste ponto. Um dos principais mal-entendidos na forma como

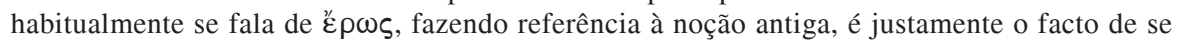
perder completamente de vista este aspecto: que, quando aplicado ao campo daquilo a que

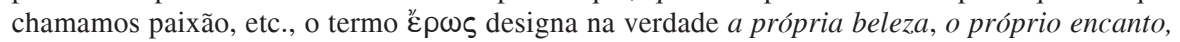
o próprio fascinante enquanto tal e exprime uma concepção da paixão como algo inteiramente provocado de fora, pela própria força do encanto que lá está naquilo que apaixona. $\mathrm{Na}$ literatura sobre este problema (v/ supra nota 4), há quem tenha usado a expressão "força

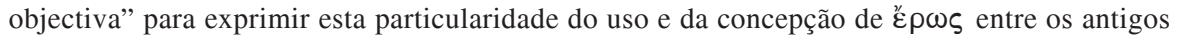


ver com o carácter epidíctico do discurso, enquanto peça com que o seu autor procura vencer o torneio retórico do Symposium - um torneio retórico em que se trata de pôr à prova a perícia e o virtuosismo com que cada orador consegue ou não bater os outros na composição do elogio de $\varepsilon^{2} \rho \omega \varsigma^{9}$. Por outro lado, é igualmente claro que o carácter "hiperbolicamente hiperbólico" do discurso de Agatão tem qualquer coisa de caricatural, exagerando e parodiando os excessos de certa retórica. Mas, vendo bem, o carácter hiperbólico do discurso não resulta apenas de procedimentos retóricos de exaltação ou da intenção de os pôr a ridículo. Mesmo que não seja inteiramente estranha aos arroubos de retórica, essa exuberante cumulação de predicados reflecte uma propriedade característica de ع̌ $\rho \omega \varsigma$ na referida acepção de encanto e invasão do encanto (sc. dos fenómenos que lhe correspondem). Com efeito, o encanto (ou a invasão de encanto) em causa na referida acepção de ع o belo-que-não-deixa-pensar-noutra-coisa, o belo potência-exterior-que--invade-e-subjuga - distingue-se precisamente pela forma como impõe o reino total de si mesmo. Apresenta-se sempre como algo de superlativo - e não apenas nestes e naqueles aspectos mas (se efectivamente tem a força invasiva e avassaladora de que se falou) justamente como algo de cumulativamente superlativo. Por outras palavras, pertence-lhe, por natureza, uma sugestão de algo pleno: o encanto sem nada que o

Gregos. Mesmo que tal formulação tenha algo de "deslocado" ou de "canhestro", não deixa de apontar para um aspecto essencial que importa não perder de vista e sem cuja consideração não se percebe bem nem o que está nos textos onde tal concepção se reflecte, nem naqueles onde (como é o caso do discurso de Aristófanes ou do "discurso" de Sócrates/Diotima, no Symposium) se produz uma radical inflexão relativamente a essa forma de entender os fenómenos em causa.

${ }^{9}$ Cf. 176e-177e. Não cabe aqui fazer nenhuma análise mais detida do que está em causa

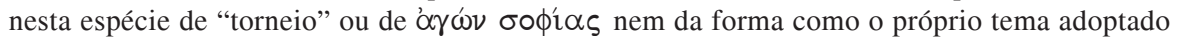

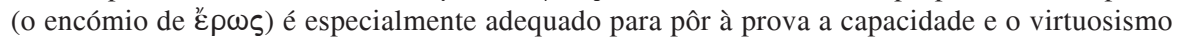
retórico dos participantes. Terá de bastar dizer, muito resumidamente, que - ao contrário do que sucede na corrente dominante da cultura ocidental contemporânea - no meio em que foi redigido o Symposium aquele है olhos. Pois, além do que vimos sobre o seu carácter exógeno, है pw também se distinguia por ser quase sempre encarado como uma potência destruidora, que atacava e subvertia as próprias

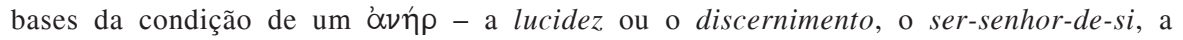
dignidade, etc. De sorte que a própria componente de doçura, etc., que lhe era reconhecida, acabava por ser percebida justamente como uma das armas a que tal força recorre para mais eficazmente levar a cabo a sua obra de engano e destruição. Numa palavra, por surpreendente

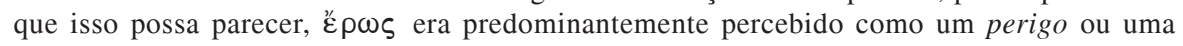
moléstia (Vó $\sigma \circ \varsigma$ ), a sujeição a ele predominantemente percebida como fraqueza, menoridade - e o seu elogio tinha o carácter de qualquer coisa como um elogio paradoxal (tal como o elogio do sal que é referido, a título de exemplo, em 177b ou os encómios de Helena, de Páris, de Busiris, de Clitemnestra, de Polifemo, dos ratos, da morte, da pobreza, da vida dos mendigos, do exílio, etc., que foram produzidos como peças epidícticas na tradição a que essa referência alude). O elogio paradoxal é especialmente adequado para pôr à prova as capacidades retóricas e o virtuosismo dos oradores, por fixar como tarefa exaltar - de forma plausível, 
restrinja ou diminua - maciça, pura, avassaladoramente tal ${ }^{10}$. E disso faz parte também chamar a si e fazer seu tudo o que é de alguma forma positivo: a acumulação (e poderia até dizer-se que um verdadeiro "açambarcamento") de predicados. "Epws (quer dizer, o fenómeno para que a referida acepção da palavra aponta) está sempre associado a qualquer coisa como uma incontida celebração de si mesmo - e essa celebração de si mesmo tem justamente a forma da superlativização irrestrita, da

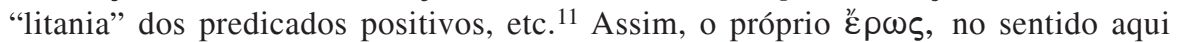
em causa, é, por natureza, hiperbólico a respeito de si - e é justamente o poder dessa extraordinária hipérbole (de que o discurso de Agatão tenta fazer eco) que lhe confere a potência invasiva e irresistível que é a sua. Nesse aspecto, o discurso de Agatão traça um retrato bem fiel do seu objecto. Pois isso que vem de fora e invade e a que os antigos chamavam " $\varepsilon \omega \varsigma$ distingue-se efectivamente pela forma como traz consigo e sugere a seu respeito nada menos do que uma ideia de plenitude - uma plenitude posta aí ao alcance, à beira de tocar.

Não é demais insistir neste ponto decisivo: independentemente de tudo o que tenha de construção retórica e até caricatural, o discurso de Agatão sugere a ideia de algo que junta em si a totalidade, o nec plus ultra dos predicados positivos - de tudo o que é desejável. Ora, ao fazê-lo, explicita um traço característico do fenómeno de encanto a que se tem feito referência. Pois o encanto que suscita enamoramento ou paixão, no sentido próprio e forte do termo, distingue-se precisamente por uma espécie de "efeito de arredondamento", em virtude do qual a fonte e objecto da paixão parece representar ou incluir em si não apenas estes e aqueles aspectos positivos e desejáveis, com exclusão de outros, mas antes de certo modo a conjugação de todos, sem qualquer excepção relevante ${ }^{12}$. Haja ou não haja nisso uma ilusão, a promessa

\footnotetext{
"conseguida", convincente - algo que não se presta a ser elogiado (e, que na verdade, muito mais facilmente se verberaria ou passaria em silêncio). Sobre estes aspectos, v/ M. J. de CARVALHO, Die Aristophanesrede in Platons Symposium, op. cit., 203ss., 556ss., 561ss.,

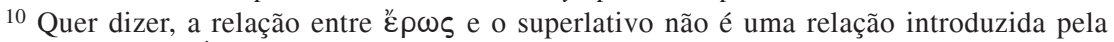
retórica de Agatão. É uma relação inerente à própria natureza de ع̌ $\rho \omega \varsigma$, no sentido referido: uma componente constitutiva do próprio fenómeno em causa. E isto de tal modo que o que é assim constitutivo e inerente não é apenas algo de superlativo, mas na verdade uma superlativa acumulação de superlativos, em virtude da qual faz parte da natureza de ع̌ $p \omega \varsigma$ não aparecer apenas como um superlativo, mas sim pura e simplesmente como o superlativo.

${ }^{11}$ Como muitas vezes se experimenta quando se tem de lidar com alguém apaixonado e com a interminável torrente de celebração do amado ou da amada que costuma produzir-se $e x$ abundantia cordis. Mas o decisivo não é apenas a verbalização, que é característica, mas sim

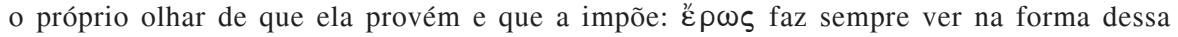

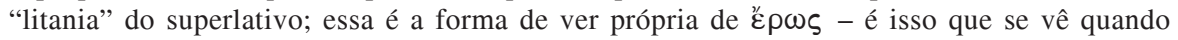
há č $\omega \varsigma$ no sentido próprio e pleno do termo.

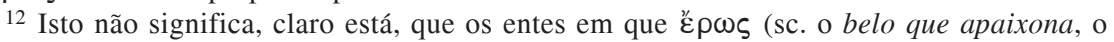
belo-que-não-deixa-pensar-noutra-coisa, o belo potência-exterior-que-invade-e-subjuga) aparece sediado possuam, efectivamente, todos os predicados positivos, sem qualquer excepção.

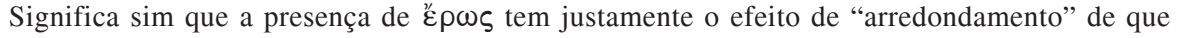
se falou, produzindo uma impressão de "pleno" - quer dizer, a impressão de uma conjugação
} 


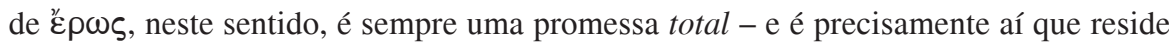
a sua extraordinária força ${ }^{13}$.

Mas há ainda um terceiro aspecto que importa não perder de vista. Como se acabou de sublinhar, no discurso de Agatão estão em causa propriedades de um fenómeno específico: o enamoramento ou aquilo a que também costumamos chamar "paixão". No fundamental, a especificidade deste fenómeno passa por dois aspectos. Em primeiro lugar, trata-se de algo relativo a seres humanos, de tal modo que são seres humanos que suscitam a paixão neste sentido - são seres humanos que aparecem no papel de $\varepsilon^{\prime} \rho \omega \varsigma$, quer dizer, como portadores do extraordinário encanto

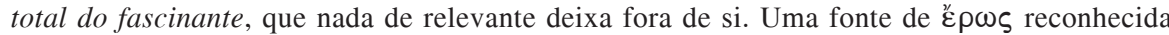
como tendo algo em falta já significa um enfraquecimento muito significativo do seu poder

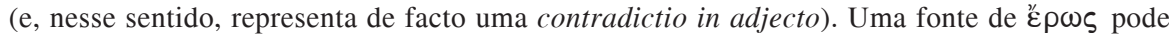
ser reconhecida como não tendo este ou aquele predicado, mas de tal modo que, ao mesmo tempo, se retira peso ou significado ao predicado em falta e ele não chega a fazer empalidecer a impressão de plenitude a que se aludiu.

${ }^{13}$ É de acentuar, neste contexto, um aspecto que tem que ver com o carácter caricatural do discurso de Agatão, que facilmente pode passar despercebido. Referiu-se que o discurso exagera e parodia procedimentos retóricos, em especial aqueles que são próprios dos discursos epidícticos. Mas aquilo que aqui importa considerar é uma outra componente desse carácter caricatural: aquela que resulta da relação entre o tema (e as teses do discurso) e o seu autor. Como acabamos de ver, Agatão celebra ع $\tilde{p} \omega \varsigma$ entendido como o encanto que enamora, aquele que aparece em alguém, desencadeando paixão a seu respeito, tornando-o de algum modo o centro do mundo. Mas, se é

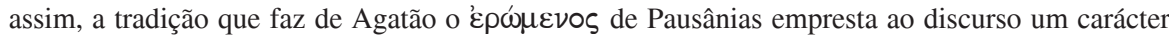
peculiar. Se Agatão é um ' $\varepsilon \rho \omega \mu \varepsilon v o s$, então a sua celebração do poder do encanto que enamora tem o efeito cómico de pôr, de certo modo, na sua boca nada menos do que um extraordinário auto-elogio. Ora, por motivos óbvios, a convenção reservava o elogio erótico aos ' $\varepsilon \rho \alpha \sigma \tau \alpha$ l. E este elogio em boca própria não só viola a convenção de distribuição de papéis na $\pi \alpha \imath \delta \varepsilon \rho \alpha \sigma \tau i$ í antiga, mas contende com os predicados de $\sigma \omega \phi \rho \circ \sigma u ́ v \eta$, etc., tradicionalmente concebidos como

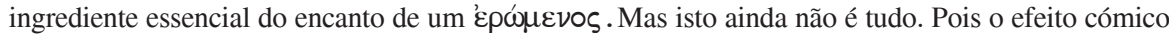
ainda se torna mais acentuado se tivermos presentes duas coisas. Em primeiro lugar, a fama de Agatão, de que encontramos eco, por exemplo, nas Thesmophoriazusae de Aristófanes. É claro que o Agatão-personagem--de-Aristófanes pode muito bem ser algo distorcido e exagerado, como é próprio de uma personagem de comédia. Mas, mesmo admitindo que o Agatão histórico tenha sido muito injustiçado por Aristófanes, isso pouco muda. Pois, como se diz na fórmula latina, semperaliquid haeret. De sorte que a referência a Agatão não podia deixar de evocar alguma sugestão de beleza postiça, atavio, artificialidade, aspecto efeminado, etc., em flagrante e cómico

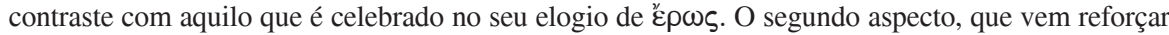
este, é a idade de Agatão na altura em que terá tido lugar o Symposium. Em 198a Aristodemo refere-

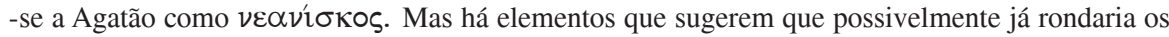

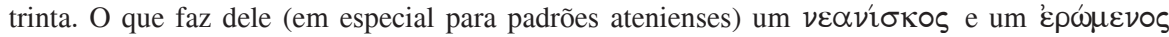
relativamente para o serôdio... Não cabe aqui discutir este segundo aspecto, que não está inteiramente esclarecido e é objecto de alguma controvérsia, tanto no que concerne a idade de Agatão, quanto no que diz respeito ao seu significado. Sobre Agatão e Pausânias, veja-se, por exemplo, a alusão feita em 177e, a claríssima referência a ambos no final do discurso de Aristófanes (193b), bem como o Protagoras 315d-e, XENOFONTE, Symposium, 8.32, ARISTÓFANES, FR. 169 (Kock), MÁRSIAS, apud F. JACOBY (ed.), Die Fragmente der griechischen Historiker, 


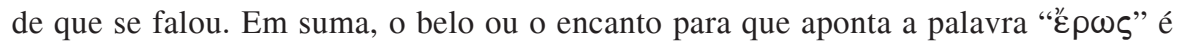
o belo ou o encanto que seres humanos podem ter aceso em si. Mas, em segundo lugar, no enamoramento ou na paixão não está em causa apenas um certo grau de encanto, mas antes qualquer coisa que se distingue justamente pela sua extraordinária intensidade - ou seja, por aquilo para que aponta o emblemático fragmento de Pródico, segundo o qual: "o desejo multiplicado por dois é certamente

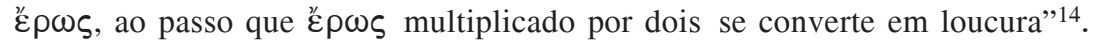

Mas, se é assim, se o discurso de Agatão tem por objecto as propriedades deste fenómeno tão específico, vendo bem, neste discurso está também em causa um modelo genérico de compreensão do Belo e da nossa relação com ele - uma compreensão segundo a qual, independentemente de pertencer ou não à esfera do

Leiden, Brill, 1923-1969, 136 F 8, ou ainda C. AELIANO, Varia historia, in: R. HERCHER (ed.), Claudii Aeliani de natura animalium libri xvii, varia historia, epistolae, fragmenta, vol. 2, Leipzig, Teubner, 1866, reed. Graz, Akademische Druck- und Verlagsanstalt, 1971, 2.21 e, finalmente, W. C. GREENE (ed.), Scholia Platonica, Haverford, American Philological Association, 1938, reed. Hildesheim, Olms, 1988, ad Sympos. 172 a, p. 447. Para uma resenha dos dados do problema e do status quaestionis, veja-se, por exemplo, F. RITSCHL, De Agathonis tragici aetate, in: IDEM, Opuscula philologica, vol. 1, Ad litteras graecas spectantia, Leipzig, Teubner, 1866, 411-435, W. R. ROBERTS, Aristophanes and Agathon, Journal of Hellenic Studies 20 (1900), 44-56, P. LÉVÊQUE, Agathon, Paris, Les Belles Lettres, 1955, em especial 28ss., J. e G. ROUX, A propos de Platon. Réflexions en marge du Phédon 62b et du Banquet, Revue de philologie, de littérature et d'histoire anciennes 35 (1961), 207-224, J. M. SNYDER, Aristophanes' Agathon as Anacreon, Hermes 102 (1974), 244-246, F. MUECKE, A Portrait of the Artist as a Young Woman, Classical Quarterly 32 (1982), 41-55, P. H. von BLANCKENHAGEN, Stage and Actors in Plato's Symposium, Greek, Roman and Byzantine Studies 34 (1993), 1-18, C. ROWE (ed.), Plato Symposium, Warminster, Aris \& Phillips, 1998, 8-9 e ad 194e4-197e8, B. HUSS, Xenophons Symposion. Ein Kommentar, Stuttgart/Leipzig, Teubner, 1999, 418, D. NAILS, The People of Plato. A Prosopography of Plato and Other Socratics, Indianapolis/Cambridge, Hackett, 2002, 8-9, 222, C. AUSTIN/S. DOUGLAS OLSON (ed.), Aristophanes Thesmophoriazusae, Oxford, Oxford University Press, 2004, ad 29-30, L. BRISSON, Agathon, Pausanias, and Diotima in Plato's Symposium: Paiderastia and Philosophia, in: J. LESHER et al. (ed.), Plato's Symposium: Issues in Interpretation and Reception, Cambridge (Mas.), Harvard University Press, 2006, 229-251, em especial 235ss.

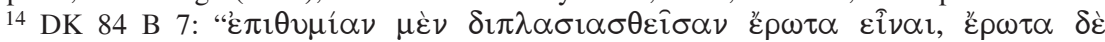

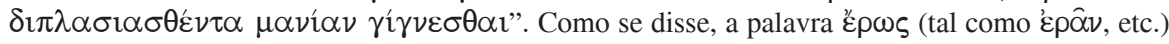
pode designar muito diversas formas de desejo que se expressam pela aposição de complementos

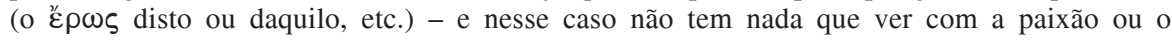
enamoramento, prestando-se a designar outras formas de desejo, com outro tipo de objectos e outros graus de intensidade menos fortes, etc. Porém, quando aparece sozinho, sem qualquer especificação

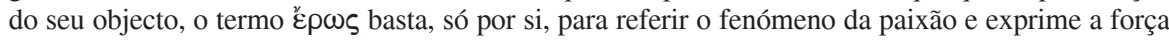
exterior de que se falou ou o desejo desencadeado pela invasão dessa força exterior. Ora, isto não é estranho ao facto de a palavra "ع $p \omega \varsigma$ ", mesmo no seu uso genérico (ou seja, quando é usada para designar outros fenómenos) parecer estar sempre de algum modo associada a uma conotação de forte intensidade. Nesse sentido, 1) um desejo intenso e, por maioria de razão, o desejo mais

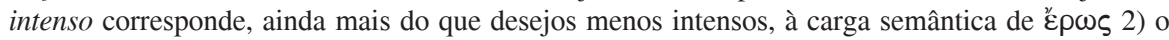
enamoramento ou a paixão é compreendido como a forma mais intensa ou violenta de $\varepsilon^{\prime} \rho \omega \varsigma$ e, por isso, 3) o enamoramento ou a paixão corresponde, mais do que qualquer outro fenómeno, à 
enamoramento (ou seja, de ter ou não como sede um ser humano) e também independentemente de produzir ou não um efeito tão avassalador (e de corresponder ou não a uma tão extraordinária soma de predicados quanto aquela que é característica de "̌p $\omega_{\zeta}$ ou do Belo que enamora), o Belo é, de todo o modo, algo que se encontra algo que vem, algo que está lá, algures, e com que entramos em relação quando obvia e impõe a sua presença. Por outras palavras, o âmbito em que se move a compreensão expressa por Agatão é um âmbito em que também se movem muitas outras, mesmo que considerem outros domínios de objectos, atendam a outros aspectos e sustentem outras teses. Esse âmbito define-se por compreender o Belo como uma das presenças possíveis - algo com que se topa, que se nos depara, que está ou surge "lá" algures, onde seja. De tal modo que se cruza ou não se cruza connosco, se dá ou não se dá a descobrir, vem ou não vem. Nessa concepção, a nossa relação com o Belo constitui-se mediante esse encontro. E a determinação daquilo que se tem nele depende justamente do que se dá a encontro ou do que vem, dos seus predicados (sejam eles tantos e tão invasivos como no caso de ع̌ $p \omega \varsigma$, ou sejam menos numerosos e de menor impacte). De sorte que a determinação do Belo e da experiência em que se entra em contacto com ele é fundamentalmente constituída e ditada pela sua própria presença (e só por ela), por aquilo que traz consigo (e só por isso).

Ora, sendo assim, no ponto de partida da intervenção de Sócrates está justamente uma tomada de posição relativamente à orientação seguida no discurso de Agatão e de tal modo que as perspectivas abertas por Sócrates acabam por pôr em causa todo este modelo.

Sócrates procura mostrar que a perspectiva desenvolvida por Agatão, em especial no que toca aos aspectos referidos, se ressente de unilateralidade. Agatão deixa-se levar naquele entusiasmo por si mesmo que é característico de é $\rho \omega \varsigma$ - e não atende a alguns aspectos decisivos do próprio complexo de fenómenos que retrata. À primeira vista, a crítica de Sócrates tem por base particularidades do campo semântico de "ع $\rho \omega \varsigma$ ", enquanto esta palavra também pode significar qualquer coisa como desejo, aspiração, ou seja, aquilo que mais inequivocamente aparece designado

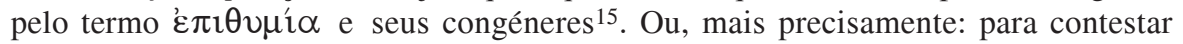
as teses defendidas por Agatão, Sócrates toma como base o facto de, acontecendo

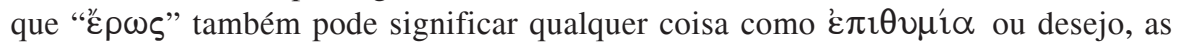

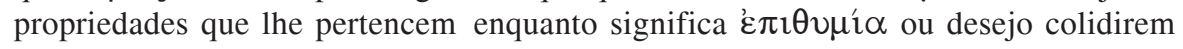
com a descrição feita por Agatão. Mas a crítica desenvolvida por Sócrates não se esgota num aproveitamento da equivocidade do termo "ع $p \omega \varsigma$ ", usada para pôr em causa o bem-fundado das palavras de Agatão e marcar pontos na disputa retórica contra ele. Pois, ao mesmo tempo, essa crítica chama a atenção para algo muito mais relevante, que não depende das particularidades do uso de uma língua, antes tem

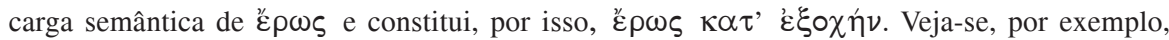
Symposium 205 e K. DOVER, Classical Greek Attitudes to Sexual Behaviour, Arethusa 6 (1973), 58-74, em especial 59.

15 Veja-se supra nota 3. Mesmo quando está em causa a própria "paixão", no sentido estrito (e ع̌p $\rho \varsigma$ significa o encanto compreendido como força exterior, etc.), a palavra também designa sempre, como que metonimicamente, a $\dot{\varepsilon} \pi \imath \theta v \mu \mathfrak{i} \alpha$ ou o desejo que $\varepsilon^{2} \omega \varsigma$, a força exterior que invade, avassala, etc., sempre desencadeia. 
que ver com uma análise dos fenómenos em causa - mais precisamente, com uma análise da própria natureza da nossa relação com o Belo, tanto no caso do enamoramento ou da paixão quanto em qualquer outro ${ }^{16}$.

Vejamos rapidamente os aspectos fundamentais ${ }^{17}$.

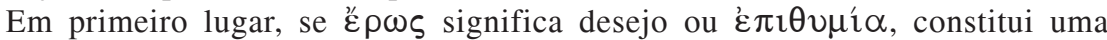
particularidade indissociável de todo o $\varepsilon$ $\rho \omega \varsigma$ enquanto $\varepsilon \pi \imath \theta v \mu \imath \dot{\imath} \alpha$ não ser pura e

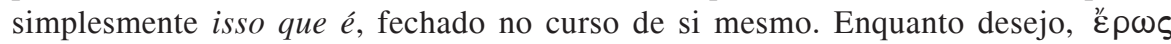

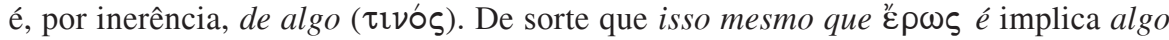
de outro. $\mathrm{Ou}$, como diz uma fórmula do texto, num oxímoro cuja incisividade pode

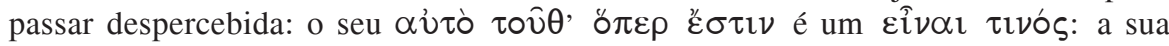
identidade (o que tem de próprio e seu) está intrinsecamente ligada a algo de outro

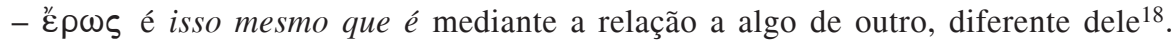

16 Ou seja, para pôr em causa o discurso de Agatão, Sócrates joga com a própria

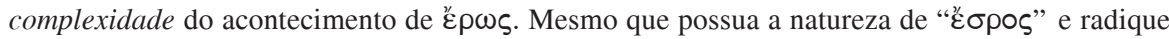
na plenitude do encanto, com tudo o que o encanto tem de maciço, pleno, "sem fissuras", है $p \omega \varsigma$ comporta também, como momento seu (ou como momento do seu "reino"), a componente desiderativa (a experiência do desejo por parte de quem sofre o seu efeito - e, por via disso, a falta, etc., que está implicada no desejo). Nesse sentido, mesmo enquanto "ह̌ $\sigma \rho \varsigma$ ", o

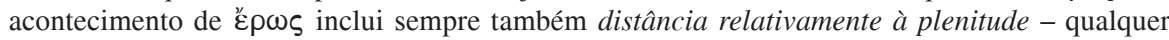
coisa justamente de não maciço, de não superlativo: qualquer coisa de "fissura", de falta, etc. O que Sócrates não faz, pelo menos num primeiro momento, é pôr em destaque esta mesma

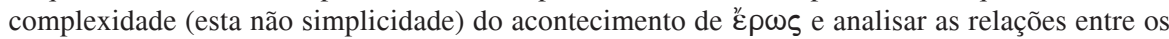
seus diversos momentos. Uma tal análise permitiria a Agatão tentar escapar às objecções de Sócrates dizendo, por exemplo, que a plenitude, etc., se situa na própria fonte do encanto e a falta não se situa nela mas sim em quem se deixa invadir pelo seu poder. Nesse aspecto, Sócrates embarca na perspectiva simplificadora do discurso de Agatão e usa-a para pôr em causa as teses defendidas por este. Mas isto não significa que se esteja apenas perante uma manobra cavilosa ou que Sócrates pura e simplesmente jogue com a equivocidade dos termos. Na verdade, o que faz é ultrapassar a forma como Agatão deixa de fora a componente desiderativa e não analisa a natureza desta, as suas condições, a sua relação com o encanto a que se rende, etc.

17 Para uma análise mais detida, v/ M. J. de CARVALHO, Problemas fundamentais de fenomenologia da finitude, Diss., Lisboa, 1996, vol. II, 1447ss.

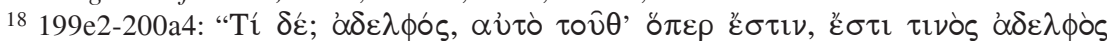

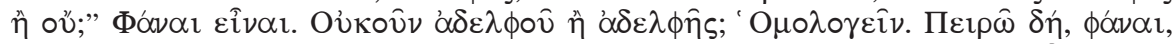

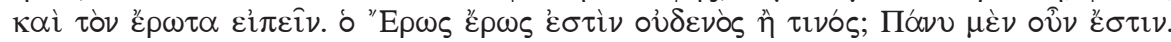

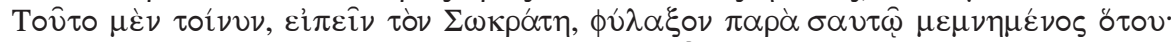

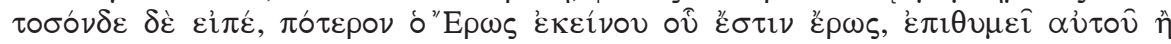

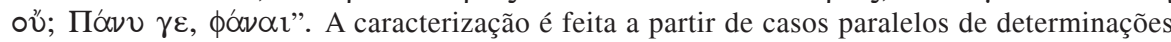
"constitutivamente relativas", como "irmão", etc., mas todos os elementos avançados no

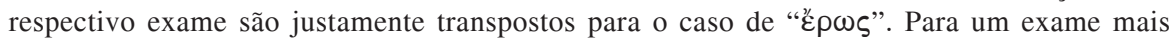

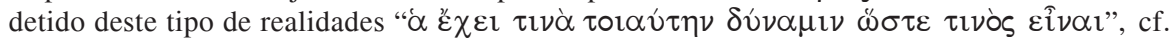
Charmides 165c4ss., 166a3ss., 168b2ss. Abstraímos aqui de uma análise mais fina das diferenças entre as várias modalidades de $\tau \imath \nu$ ò $\varepsilon^{\imath} \tilde{\nu} \alpha \mathbf{l}$, bem como de uma discussão dos diversos problemas que põem em relação ao diálogo entre Sócrates e Agatão. Veja-se, por exemplo, R. E. ALLEN, A Note on the Elenchus of Agathon: Symposium 199-201, The Monist 50 (1966), 460-463, e T. B. MOONEY, The Dialectical Interchange Between Agathon and Sócrates: Symposium 198b-201d, Antichton 28 (1994), 16-24. 
Mas, em segundo lugar, constitui também uma propriedade indissociável de todo o

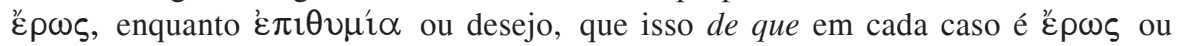
$\varepsilon \pi \mathrm{\varepsilon} \theta 0 \mu \mathrm{i} \alpha$ (esse outro por que passa ou a que é relativa a sua identidade) não esteja

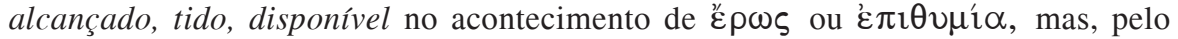
contrário, seja algo que falta, de que há carência, que se mantém fora de alcance nesse acontecimento ${ }^{19}$. Quer dizer, a ausência, a carência desse outro a que o desejo é relativo e mediante o qual ع̌p $\rho \varsigma$ é si próprio constitui uma condição indispensável da sua ocorrência. Não se trata somente de haver uma relação com algo de outro e de, para além disso, essa relação ser colateralmente de algum modo marcada por uma falta. Não. A relação ao outro que é constitutiva da identidade do desejo é uma relação de falta, fulcralmente marcada pela falta daquilo a que o desejo se reporta. O desejo é isso que é na e através da falta dessa outra realidade a que se refere - a qual só

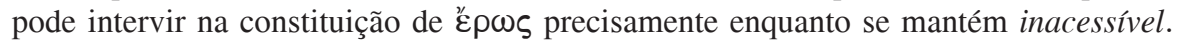

Ora, é daqui que parte o ataque a Agatão e se começam a desenhar como que fissuras nessa figura de plenitude e acumulação de predicados positivos que o seu discurso celebra. Pois, sendo assim, deixa de ser possível reconhecer pelo menos um dos elementos fundamentais dessa celebração de plenitude que se encontra desenhada

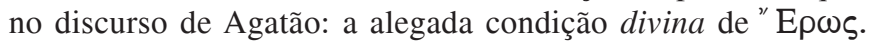

Para mostrar que não se pode tratar de um deus, Sócrates introduz uma premissa

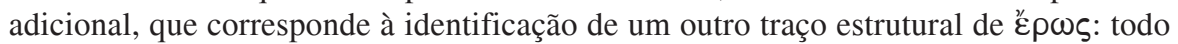

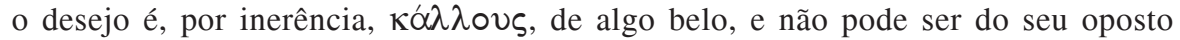
$(\alpha \text { ‘ } \sigma \chi 0 \cup \varsigma)^{20}$. Significa isso que o outro que está implicado na realidade própria de cada desejo não é um outro qualquer, de forma perfeitamente indiferente. Enquanto tal, todo o desejo está, por natureza, orientado para um tipo bem definido de

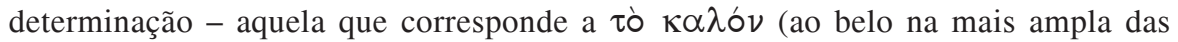
acepções que, como acentua o próprio curso do diálogo, inclui também o bom: $\tau \not \alpha \gamma \alpha \theta \delta$ $v$ - de sorte que, para impedir entendimentos restritivos e para sugerir toda a amplitude que a noção comporta, se prefere traduzir a expressão por "belo/bom") ${ }^{21}$. Podendo os desejos ser de muitas e variadas coisas, caracteriza-os por inerência que

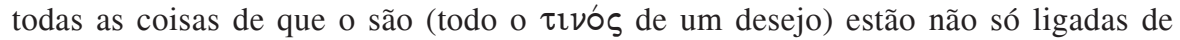
algum modo ao "belo/bom", mas também revestidas desta mesma determinação: de alguma maneira "identificadas" com ela, postas em equivalência a ela. De outro modo, não podem constituir o $\tau \imath \nu o ́ s$ de um desejo. Em suma, o que caracteriza

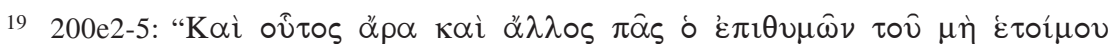

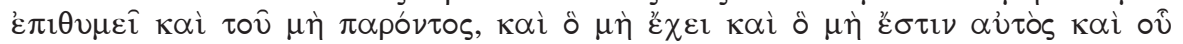

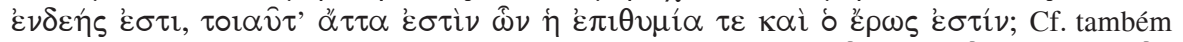

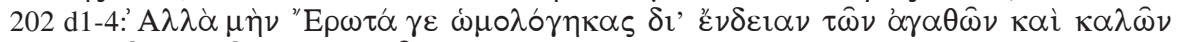

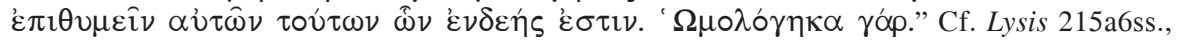
221d6ss. A sequência dos aspectos fixados nesta parte preliminar da intervenção de Sócrates

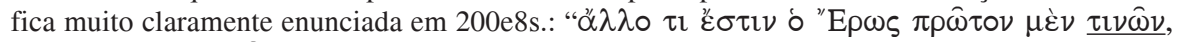

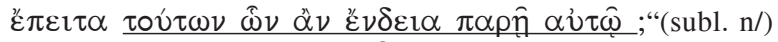

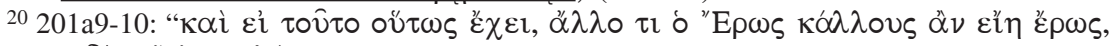

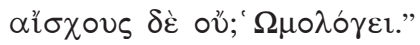

${ }^{21}$ Cf. 201c1-3. 
¿̌p

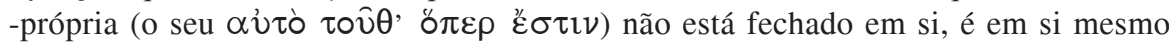
relativo a algo de belo/bom, de que o próprio desejo enquanto tal carece e a que se reporta justamente na (e pela) carência dele, ou seja, por isso estar em falta.

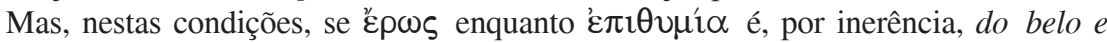
do bom, estas determinações têm por força de constituir algo que falta à própria realidade de ¿ $^{2} \omega \varsigma$ - de que esta precisamente tem carência. Ou seja, no acontecimento

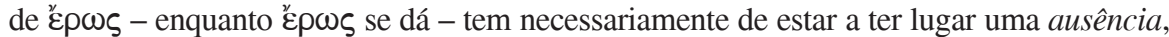

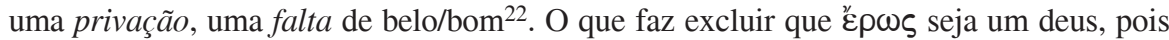
aos deuses pertence justamente a plena posse de tais determinações ${ }^{23}$.

Mas, prossegue o argumento, ainda há mais. Pois, se é assim, parece inevitável ter de se reconhecer que, enquanto $\varepsilon \pi \imath \theta \nu \mu \imath \alpha$ (quer dizer, enquanto algo que por sua

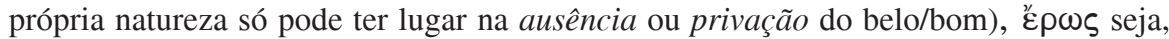
então, em si mesmo algo de feio, deformado, e, além disso, também algo de mau ou de $v i l^{24}$. O que parece precipitar ह̌p $\omega_{\varsigma}$ dos fastígios de perfeição e plenitude em que Agatão o situava para qualquer coisa muito diferente e até oposta - desenhando-se

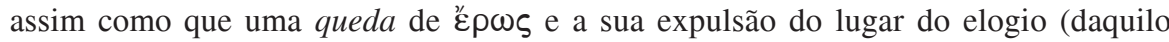
que só é digno de admiração) para a região daquilo que, pelo contrário, não merece

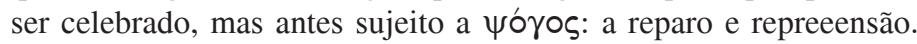

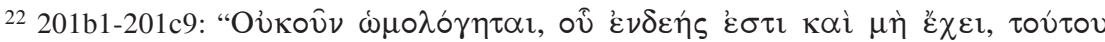

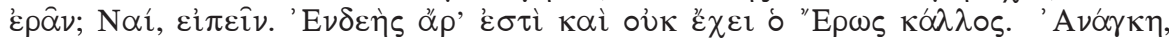

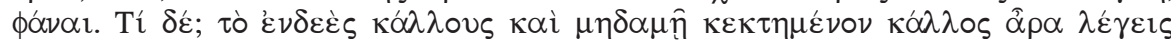

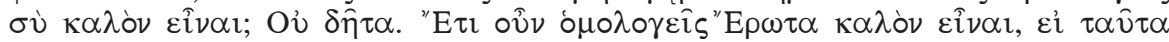

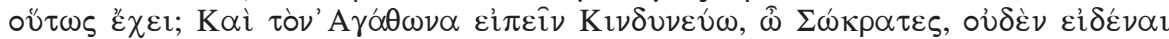

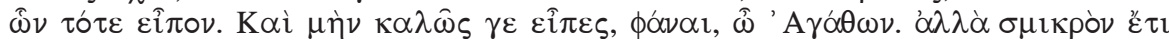

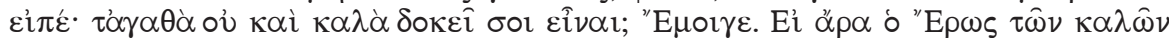

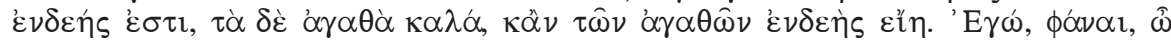

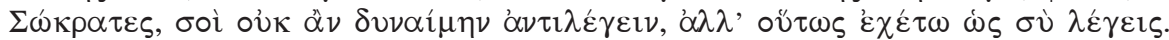

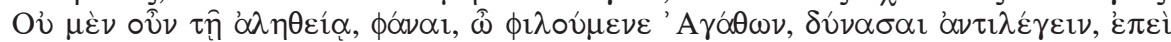
$\Sigma \omega \kappa \rho \alpha ́ \alpha \varepsilon \imath ~ \gamma \varepsilon$ oủ $\delta \dot{v} \nu \chi \alpha \lambda \varepsilon \pi o ́ v . "$

${ }^{23}$ Cf. 202 b-d.

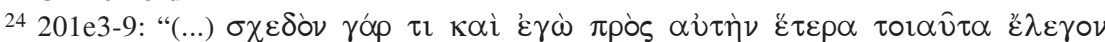

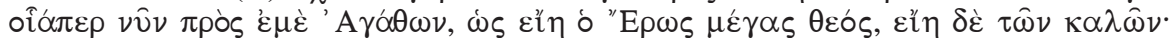

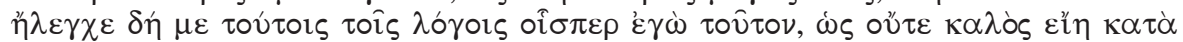

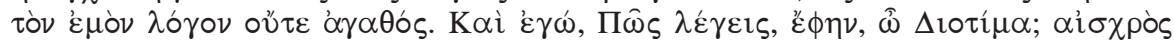

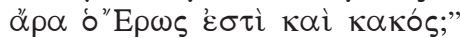

Para se perceber bem o argumento, é preciso ter em conta um ponto que muitas vezes não é devidamente atendido na sua interpretação. No caso de um indivíduo, o facto de desejar algo de belo significa apenas que não possui o belo que deseja (e só esse - de tal modo que nada impede que, quanto ao mais, seja até "carregado" de beleza). Mas Sócrates está a reportar-se ao discurso de Agatão. Como vimos, a "lógica" do discurso de Agatão é uma "lógica" de "totalização" - desde logo, porque está em causa um único poder, ou uma única força, responsável por todas as paixões. Ora, se há uma única potência do desejo, que actua em todas as paixões, já não se lhe aplica o que vale para um indivíduo: essa potência distinguir-se-á pela falta "acumulada" de todo o $\kappa \alpha \lambda o ́ \nu$ desejado em todas as paixões. Isto por um lado. Pois, por outro lado, Sócrates também pode estar ao mesmo tempo a aludir à óptica "totalizante" que é característica da própria paixão enquanto 


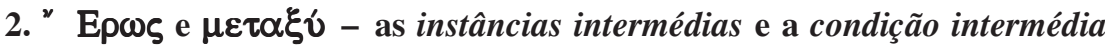 segundo Sócrates/Diotima.}

Ora, é aqui que intervém Diotima a contestar o bem-fundado desta consequência ${ }^{25}$. Pois a alternativa entre o belo e o feio ou o bom e o vil não é uma alternativa absoluta, tal que tenha de ocorrer forçosamente um ou o outro dos seus termos, sem terceira possibilidade. Do mesmo modo que, segundo Diotima, também a alternativa entre $\sigma o \phi^{\prime} \alpha$ e $\alpha^{\prime} \mu \alpha \theta^{\prime} i \alpha$, entre o saber e a ignorância ${ }^{26}$, ou a alternativa entre o mortal e o imortal não é uma alternativa absoluta - tal que tenha de ocorrer um ou o outro dos seus termos, sem terceira possibilidade. Não. Em qualquer destes casos há uma terceira possibilidade, há algo de intermédio entre esses termos - um $\mu \varepsilon \tau \alpha \xi u ́$ entre eles, que se caracteriza por não ser nem um nem o outro: por diferir de ambos. E é nessa posição, como qualquer coisa de intermédio, que, segundo Diotima, se situa है $\rho \omega \varsigma$.

Para não perder o fio do desenvolvimento que se segue no discurso de Sócrates/ Diotima, importa ter presentes sobretudo três aspectos.

Em primeiro lugar, Diotima põe em evidência que, em certos casos, a relação de oposição não é contraditória - há algo de intermédio, um $\mu \varepsilon \tau \alpha \xi \hat{v}$ ou uma terceira possibilidade. Mas, por outro lado, aquilo que foca não são pura e simplesmente ilustrações avulsas disso, casos soltos. Não. Diotima insiste numa relação de copertença entre as diferentes formas de $\mu \varepsilon \tau \alpha \xi \hat{v}$ para que chama a atenção e exprime com toda a nitidez esse vínculo de co-pertença: todas as instâncias intermédias constituem precisamente características de $\varepsilon^{\prime} \rho \omega \varsigma$ - que surge, assim, como uma realidade especialmente ligada a este tipo de determinações, multiplamente marcada por elas, que envolve uma confluência de determinações intermédias desta ordem. Ou seja, além de chamar a atenção para o cabimento de instâncias ou determinações intermédias, Diotima também põe em relevo que há algo - e esse algo é ع̌ $p \omega \varsigma$ -

tal (fenómeno que, como vimos, está no centro do discurso de Agatão): a paixão vê o seu objecto como a quintessência do Kaגóv (de certo modo, o belo ou o encanto "todo") e, por isso, vive-se a si mesma como falta ou "deserto" desse "encanto total".

${ }^{25}$ Dizemos que Diotima intervém, porque, como vimos, Sócrates atribui a Diotima a autoria desta inflexão que o próprio Sócrates volta a produzir no seu diálogo com Agatão. V/ supra, nota 1. Por uma questão de economia, naquilo que se segue referimo-nos quase sempre a Diotima. Mas de facto também poderíamos dizer Sócrates/Diotima ou pura e simplesmente Sócrates. O importante é que nos estamos a referir a uma personagem não definida pela sua "identidade", mas pelo exercício de uma função (a personagem que interroga, põe em causa, abre novas perspectivas: a personagem "socrática", no sentido funcional do termo), personagem essa que é desempenhada por Diotima junto de Sócrates e por Sócrates junto de Agatão (e também junto do leitor).

${ }^{26}$ Não cabe analisar aqui os campos semânticos correspondentes às noções de $\sigma 0 \phi i ́ \alpha$ e de $\alpha^{\prime} \mu \alpha \theta i ́ \alpha$, tal como estão usadas nos textos pré-platónicos, nos textos coevos e no corpus platonicum. Tal análise implicaria desenvolvimentos muito longos, que excedem por completo o quadro deste estudo. De resto, Diotima começa por usar estas expressões num sentido lato e vago (com uma amplitude de sentido grosso modo correspondente à dos termos portugueses a que recorremos para as traduzir). E, como já veremos, é o próprio desenvolvimento ulterior do argumento que se encarrega de precisar qual é, concretamente, o sentido em que Diotima usa estas noções. 
que se distingue precisamente pela circunstância de reunir em si (ou ser formado por) um complexo de determinações intermédias, de tal modo que esta peculiar

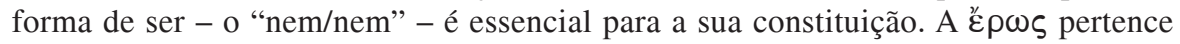

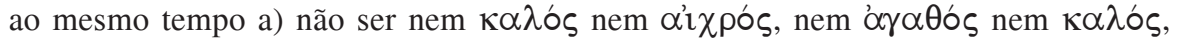

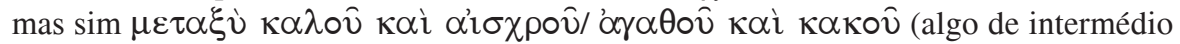

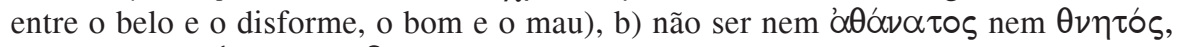

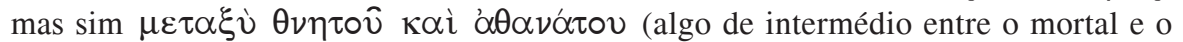

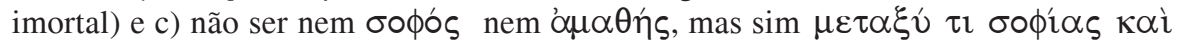
'au $\alpha \theta^{\prime} \alpha \varsigma$ (algo de intermédio entre o saber e a ignorância) ${ }^{27}$.

Em segundo lugar, a identificação que Diotima faz das instâncias intermédias está marcada por uma peculiar duplicidade: aquilo que, primeiro, aparece com um determinado "rosto", surge de repente, sem aviso ou qualquer chamada de atenção, com uma identificação diferente (de sorte que é abandonada a primeira e a segunda é que passa a ser desenvolvida e a desempenhar um papel preponderante no curso ulterior da exposição) ${ }^{28}$.

27 Cf. 202 d8 ss., 203e1ss., 203c 1ss., 203e5ss.

28 A duplicidade que é manifesta a respeito da identificação concreta do $\mu \varepsilon \tau \alpha \xi \grave{v} \theta \nu \eta \tau ం \hat{v}$

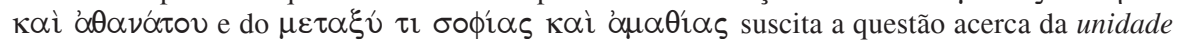
do discurso de Sócrates/Diotima. Diversos autores têm posto em relevo os vários aspectos de desencontro interno no discurso de Sócrates/Diotima e sustentado a tese de que tem um carácter compósito, com agregação de elementos de proveniência e teor diversos, de tal modo que nele se justapõem ou convivem concepções não inteiramente concordantes entre si. Veja-se, por exemplo, H. KOLLER, Die Komposition des platonischen Symposions, Diss., Zürich, 1948, 36s., M. LANDMANN, Platons Traktat von den drei Unsterblichkeiten. Die Urzelle von Conv. 207a-212a, Zeitschrift für philosophische Forschung 10 (1956), 161-190 e J. WIPPERN. Eros und Unsterblichkeit in der Diotima-Rede des Symposions, in: H. FLASHAR/K. GAISER (ed.), Synusia. Festschrift für W. Schadewaldt. Pfullingen, Neske, 1965, 123-159. Não cabe discutir aqui todos os aspectos relevantes para a apreciação deste problema. Mas importa esclarecer que partido se julga dever tomar nesta matéria, até mesmo porque a análise que aqui se apresenta joga justamente com elementos das diversas partes do discurso de Sócrates/Diotima e supõe, nessa medida, a sua unidade. Que o discurso comporta elementos desencontrados, isso parece inegável. Mas esse desencontro não significa necessariamente que se trate de um "patchwork" inacabado, a que Platão, por qualquer motivo, não chegou a dar a última demão, nem tampouco que os diversos elementos desencontrados pertençam a fases diferentes do desenvolvimento do pensamento platónico, de tal modo que a chave para a identificação do respectivo nexo é cronológica, tem que ver com evoluções doutrinais, etc. O desencontro pode muito bem ter que ver com a peculiar forma de comunicação que é própria do corpus platonicum, forma de comunicação essa que privilegia o inacabado, a provocação e mobilização do leitor, o permanente pôr à prova da sua capacidade de verificar e submeter os enunciados a um juízo crítico. Ou seja, pode muito bem acontecer que o desencontro seja propositado, que o discurso de Sócrates/Diotima seja como as imagens de Sileno a que Alcibíades faz referência para retratar Sócrates (215-216), imagens que se abrem e cujo interior contrasta com o aspecto de Sileno do exterior. Pode acontecer que o leitor seja chamado a fazer com o discurso de Sócrates/Diotima aquele exercício de abertura ou de descoberta do que se acha escondido atrás do aspecto mais imediato e mais óbvio, para que remete a referência de Alcibíades, e que as várias camadas do discurso correspondam justamente a esse jogo de transformação de que as imagens dos silenos são um emblema. Em suma, a interpretação que 
Assim, a instância intermédia entre o mortal e o imortal aparece inicialmente identificada por recurso a uma categoria mitológica, a categoria de $\delta \alpha i \mu \omega \nu .{ }^{29}$ Mas, na continuação da análise, regista-se uma reidentificação deste $\mu \varepsilon \tau \alpha \xi \hat{v}$ - e o que acaba por ser apresentado como intermédio entre o mortal e o imortal é a $\gamma \dot{\varepsilon} \nu \nu \eta \sigma ı \varsigma$

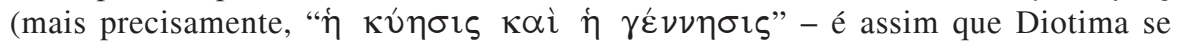
exprime em 206c7s.: a capacidade de geração ou a fecundidade própria dos seres vivos). ${ }^{30}$

se propõe explora uma leitura do discurso de Sócrates/Diotima no modo da "abertura dos silenos". Sobre este modelo de interpretação veja-se em especial K. GAISER, Esteriorità e interiorità dei logoi socratici: Simposio 212c-223d, in: IDEM, Platone come scrittore filosofico. Saggi sull'ermeneutica dei dialoghi platonici, Napoli, Bibliopolis, 1984, 55-76.

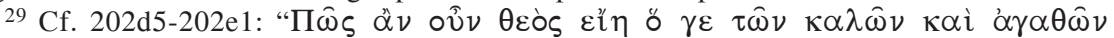

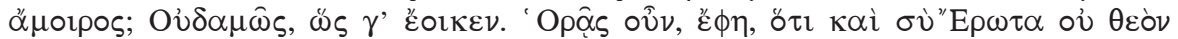

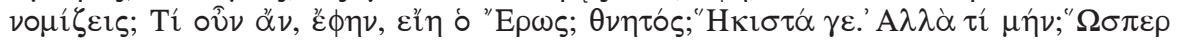

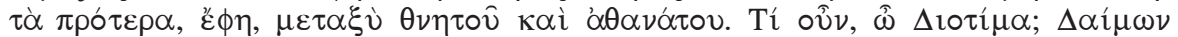

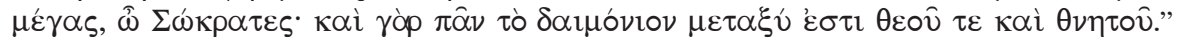

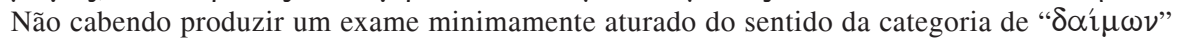
(nem no que diz respeito ao seu uso no empreendimento filosófico de Platão, nem no que toca ao quadro de categorias culturais, religiosas, etc. em que esse uso se insere e a que faz referência), remete-se para a ampla discussão de que tanto um quanto o outro aspecto têm sido objecto e de que se dão referências bibliográficas no Apêndice I.

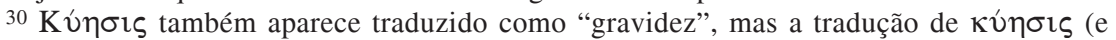

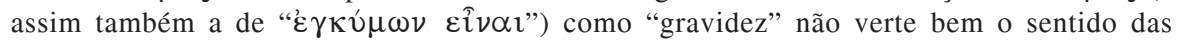
expressões. No fundamental, o defeito resulta de a noção de gravidez, enquanto consigna a condição da mulher ou da fêmea depois da inseminação (o estado que corresponde à gestação da criança no ventre materno), ser demasiado estreita para traduzir aquilo de que se trata no

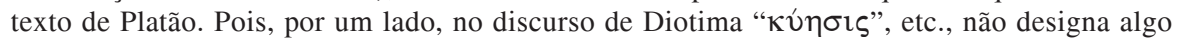
exclusivo da mulher (mas qualquer coisa que ocorre também no homem). É certo que, na maior

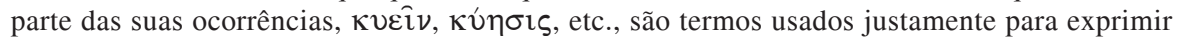
a gravidez, a manifestação especificamente feminina da fecundidade. Mas, como bem mostra K. PHILIPP, op. cit. infra, 82s., Diotima usa este vocabulário "feminino" para descrever justamente aquilo que se passa no sexo masculino, aquilo que o leva à procriação, etc. Mas, por outro lado, a questão não é principalmente uma questão de género. Com efeito, essa maior extensão (a aplicação aos dois géneros) decorre precisamente de Diotima não ter em vista propriamente a situação decorrente do ter sido fecundado, mas sim a própria fecundidade enquanto tal - i.e., esse "excesso" sobre si próprio que faz que o ser vivo não fique (ou não se esgote) em si, antes gere em si e a partir de si o princípio de outro ser vivo. Em suma, o que está em causa é o peculiar fenómeno em virtude do qual um ser vivo se torna portador de outro. De sorte que, independentemente da diversidade das funções que desempenham no processo procriativo, tanto o macho quanto a fêmea se caracterizam por aquilo que é designado

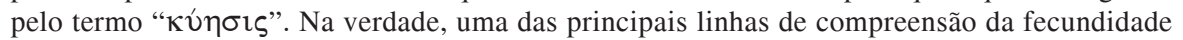
dos seres vivos, da sua reprodução, etc., que encontramos expressa tanto em textos de natureza mais científica, quanto noutros (por exemplo, na tragédia) entende a fecundidade, o poder de geração (o excesso do ser vivo sobre si mesmo, mediante o qual se constituem novos seres vivos) como tendo lugar exclusivamente no progenitor do sexo masculino, enquanto gera a semente que a mãe não faz mais do que receber e alimentar. Veja-se, por exemplo, o que 


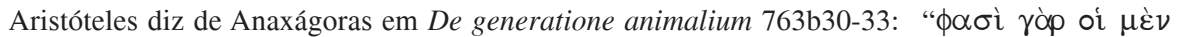

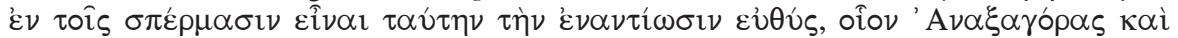

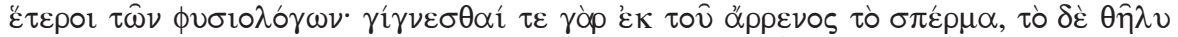

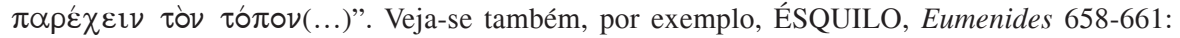

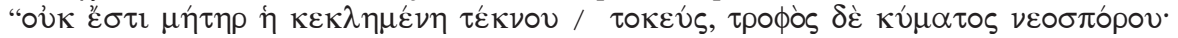

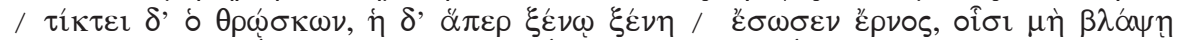
өદós." - ou ainda HÍPON, DK 38 A 13 e DIÓGENES DE APOLÓNIA, DK 64 A 27. De qualquer forma, e a despeito destas diferenças, o fundamental daquilo que está em causa nas noções de

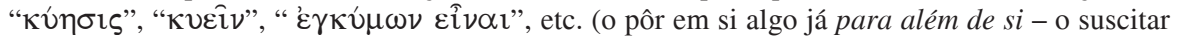
e ter em si já o outro - e, por outro lado, também o carácter ainda só incoativo, ainda não acabado, ainda por consumar, dessa presença do outro - excessivo já sobre o próprio, mas por outro lado, ainda "aquém de si", ainda não libertado para si mesmo, para a plenitude de si) também pode, por uma questão de economia, ser traduzido pelo conceito de gravidez.

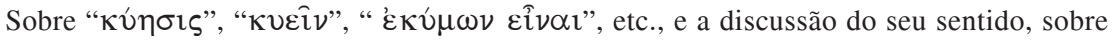
as concepções que acabámos de referir, bem como sobre as particularidades do entendimento platónico do processo de reprodução, em cujo quadro as noções em causa são utilizadas e devem ser compreendidas, cf. A. HUG/H. SCHÖNE (ed.), Platons ausgewählte Schriften, 5. Teil: Symposion, Leipzig/Berlin, Teubner, 1909³, ad 206b12, L. ROBIN, La théorie platonicienne de l'amour, Paris, Alcan, 1908, 1933, 16-17, A. W. VERRALL (ed.), The Eumenides of Aeschylus, London, Macmillan, 1908, xlvi ss., ad 660-664, M. CROISET, Le rôle d'Apollon dans Les Eumenides d'Eschyle, Revue des Études Grecques 32 (1919), 100112, R. G. BURY (ed.), The Symposium of Plato, Cambridge, Heffer, 1932, XXXVIII, 110, H. CHERNISS, Aristotle's Criticism of Presocratic Philosophy, Baltimore, Johns Hopkins Press, 1935, 276, U. GALLI (ed.), Platone Il simposio, Torino, Chiantore, 1935, ad 206b, c, F. M. CORNFORD, Plato's Cosmology. The Timaeus of Plato Translated with a Running Commentary, London, Routledge \& Kegan Paul 1937, 187, K. KERÉNYI, Hermes der Seelenführer, Zürich, Rhein-Verlag, 1944, 66 ss., F. SOLMSEN, Hesiod and Aeschylus, Ithaca (NY), Cornell University Press, 1949, $2^{\text {a }}$ ed. aum., Ithaca (NY)/London, Cornell University Press, 1995, 191s, 194ss., E. LESKY, Die Zeugungs- und Vererbungslehren der Antike und ihr Nachwirken (Abhandlungen der Akademie der Wissenschaften und der Literatur in Mainz, Geistes- und Sozialwissenschaftliche K1. 1950, 19), Wiesbaden, Steiner, 1950, em especial 1277ss., R. B. ONIANS, The Origins of European Thought about the Body, the Mind, the Soul, the World, Time and Fate. New Interpretations of Greek, Roman and Kindred Evidence about Some Basic Jewish and Christian Beliefs, Cambridge, University Press, 1951, 112, P. GROENEBOOM (ed.), Aeschylus' Eumeniden, Groningen, Wolters, 1952, ad 657-666, A. PERETTI, La teoria della generazione patrilinea in Eschilo, La parola del passato 11 (1956), 241-262, M. LANDMANN, Platons Traktat von den drei Unsterblichkeiten, Zeitschrift für philosophische Forschung 10 (1956), 161-190, em especial 178ss., M. DELCOURT, Oreste et Alcméon. Étude sur la projection légendaire du matricide en Grèce, Paris, Les Belles Lettres, 1959, 85, n., R. KUHNS, The House, the City and the Judge. The Growth of Moral Awareness in the Oresteia, Indianapolis, Bobbs-Merrill, 1962, 45ss., J.-P. VERNANT, Hestia-Hermès. Sur l'expression religieuse de l'espace et du mouvement chez les Grecs, L'Homme, Revue française d'anthropologie 3 (1963), 12-50 (= IDEM/P. VIDAL-NAQUET, La Grèce ancienne, vol. 2, L'espace et le temps, Paris, Seuil, 1991, 47-99, em especial 56s.), J. S. MORRISON, Four Notes on Plato's Symposion, Classical Quarterly, 14 (1964), 42-55, em especial 52ss., K. KERÉNYI, Der grosse Daimon des Symposion, in: IDEM, Humanistische Seelenforschung, München/Wien, Langen Müller, 1966, 301, G. THOMPSON (ed.), The Oresteia of Aeschylus, vol. II, $2^{a}$ ed. rev. e aum., Amsterdam/Prague, Hakkert/Academia, 1966, ad Eum. 658-9, E. BENVENISTE, Le vocabulaire des institutions indo-européennes, vol. II, Paris, Minuit, 
1969, 183ss., W. RÖSLER, Reflexe vorsokratischen Denkens bei Aischylos, Meisenheim a. G., Hain, 1970, 73-87, A. LEBECK, The Oresteia. A Study in Language and Structure, Washington, Center for Hellenic Studies, 1971, 124ss., G. VLASTOS, Platonic Studies, Princeton (N.J.), Princeton University Press, 1973, 21, B. VICKERS, Towards Greek Tragedy, London, Longman, 1973, 414s., D. CLAY, Platonic Studies and the Study of Plato, Arion 2 (1975), 116-132, em especial 124s., P. W. CUMMINGS, Eros as Procreation in Beauty, Apeiron 10 (1976), 23-28, M. F. BURNYEAT, Socratic Midwifery, Platonic Inspiration, Bulletin of the Institute of Classical Studies 24 (1977), 7-17, em especial 14, P. C. PLASS, Plato's Pregnant Lover, Symbolae Osloenses 53 (1978), 47-55, F. I. ZEITLIN The Dynamics of Misogyny: Myth and Mythmaking in the 'Oresteia', Arethusa, 11 (1978), 149-184, em especial 167ss., K. PHILIPP, Zeugung als Denkform in Platons geschriebener Lehre. Die stilistische und ontologische Bedeutung des Verbs $\gamma \varepsilon \nu \nu \alpha \hat{\nu}$ und anderer biologischer Metaphern in Platons erhaltenen Werken, Zürich, Juris, 1980, 78s., 80ss., 105ss., 131ss., 135, 186, 191-193, K. DOVER (ed.), Plato Symposium, Cambridge, University Press, 1980, reimpr.: 1993, 147, G. VLASTOS, Platonic Studies, Princeton (NJ), Princeton University Press, 1981, 21 nota, 424, G. E. R. LLOYD, Science, Folklore and Ideology. Studies in Life Sciences in Ancient Greece, Cambridge, Cambridge University Press, 1983, 86ss., G. R. LAMBERT, Plato's Household Topos: A Formative Influence on Ancient Educational and Social Theory, Prudentia 16 (1984), 17-32, C. W. WILlinK (ed.), Euripides Orestes, Oxford, Clarendon Press, 1986, ad 551-6, M. C. STOKES, Platonic Conversations. Drama and Dialectic in Three Dialogues, Baltimore, The Johns Hopkins University Press, 1986, 161ss., V. SOLEIM; A Greek Dream - to Render Women Superfluous, Social Science Information 25 (1986), 67-82, I. CHIRASSI COLOMBO, Giochi dell'imaginario greco. Solipssimi spermatici, partenogenesi, gravidanze maschili, in: M. SBISÀ (ed.), I figli della scienza. Riflessioni sulla reproduzione artificiale, Milano, Emme, 1988, 111-128, J. TOMIN, Socratic Midwifery, Classical Quarterly 37 (1987), 97-102, E. F. KITTAY, Metaphor - Its Cognitive Force and Linguistic Structure, Oxford, Clarendon Press, 1987, 278ss., R. G WENGERT, The Paradox of the Midwife, History of Philosophy Quarterly 5 (1988), 3-10, V. SONGE-M $\varnothing$ LLER, Sexualität und Philosophie in Platons Symposion, Symbolae Osloenses 63 (1988), 25-50, A. MOTTE, Platon et la dimension religieuse de la procréation, Kernos 2 (1989), 157-173, A. H. SOMMERSTEIN (ed.), Aeschylus Eumenides, Cambridge, Cambridge University Press, 1989, ad 657-66, N. LORAUX, Les enfants d'Athéna. Idées athéniennes sur la citoyenneté et la division des sexes, Paris, Maspéro, 1981, Paris, Éditions de la Découverte, 1990, 129s., J. WINKLER, The Constraints of Desire. The Anthropology of Sex and Gender in Ancient Greece, N.Y., Routledge, 1990, 231, D. M. HALPERIN, One Hundred Years of Homosexuality and Other Essays on Greek Love, N.Y., Routledge, 1990, 129ss., 139ss.,203s., G. BONELLI, Socrate Sileno. Dinamica erotica e figurazione scenica nel Convito di Platone, Torino, Celid, 1991, 62-66, O. LONGO, Il figlio dell' amazone: biologia e mito, Materiali e discussioni per l'analisi dei testi classici 26 (1991), 9-29, R. PADEL, In and Out of the Mind. Greek Images of the Tragic Self, Princeton (N.J.), Princeton University Press, 1992, 106ss., E. E. PENDER, Spiritual Pregnancy in Plato's Symposium, The Classical Quarterly NS. 42 (1992), 72-86, H. PATZER, Physis. Grundlegung zu einer Geschichte des Wortes, Stuttgart, Steiner, 1993, 271s., D. SUSANETTI, Eros o la ricerca dell'unità, Atti dell'Istituto Veneto di Scienze, Lettere e Arti 154 (1995-96), 469-492, em especial 489s., A. THIVEL, Die Zeugungslehren bei Hippokrates und den Vorsokratikern, in: R. WITTERN/P. PELLEGRIN (ed.), Hippokratische Medizin und antike Philosophie. Verhandlungen des VIII. Internationalen Hippokrates-Kolloquiums, Hildesheim/N.Y., Olms, 1996, 3-13, F. ZEITLIN, Playing the Other. Gender and Society in Classical Greek Literature, Chicago/London, The University of Chicago Press, 1996, 109s., C. PIRAS, Vergessen ist das Ausgehen der Erkenntnis. Eros, Mythos und Gedächtnis in Platons Symposion, Frankfurt a. 
Do mesmo modo, a instância intermédia entre o saber e a ignorância aparece

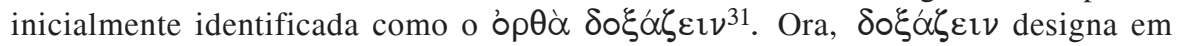
Platão aquilo que acontece quando não se está em hesitação ou dúvida sobre isto ou aquilo, antes se tem por adquirido ou assente que as coisas são deste ou daquele modo $^{32}$. Grosseiramente, podemos dizer que a expressão designa a adopção de juízos.

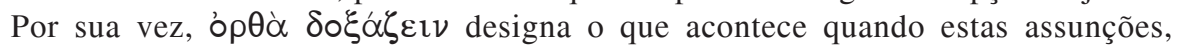
assentamentos ou juízos 1) acertam, são correctos, correspondem àquilo que efectivamente está a ocorrer, mas 2) por outro lado não são capazes de dar conta

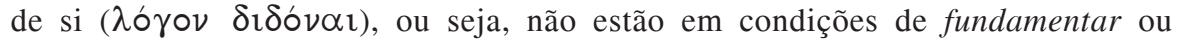
justificar cabalmente a decisão em que assentam, de tal modo que são $\alpha$ - $\lambda$ o $\alpha \alpha-$

M., Lang, 1997, 99ss., 103ss, B. S. THORNTON, Eros: the Myth of Ancient Greek Sexuality, Boulder, Westview Press, 1997, 144s., 155, 259, K. SIER, Die Rede der Diotima. Untersuchungen zum platonischen Symposium, Stuttgart, Teubner, 1997, 109ss., 222s, 233s., M. FINKELBERG, Plato's Language of Love and the Female, The Harvard Theological Review 90 (1997), 231-261, em especial 238ss., A. GUARDASOLE, Tragedia e medicina nell' Atene del V secolo A.C., Napoli, M. D’Auria, 2000, 143ss., 153s., R. G. EDMONDS, Socrates the Beautiful: Role Reversal and Midwifery in Plato's Symposium, Transactions of the American Philological Association 130 (2000), 261-285, em especial 264ss., F. C. C. SHEFFIELD, Psychic Pregnancy and Platonic Epistemology, Oxford Studies in Ancient Philosophy 20 (2001), 1-33, J.-B. BONNARD, Le complexe de Zeus: représentations de la paternité en Grèce ancienne, Paris, Publications de la Sorbonne, 2004, F. C. C. SHEFFIELD, Plato's Symposium. The Ethics of Desire, Oxford, Oxford University Press, 2006, 86ss., A. HOBBS, Female Imagery in Plato, in: J. LESHER et al. (ed.), Plato's Symposium: Issues in Interpretation and Reception, Cambridge (Mas.), Harvard University Press, 2006, 252-271. Como já se verá, o que se encontra no dicurso de Sócrates/Diotima não é apenas uma reidentificação do $\mu \varepsilon \tau \alpha \xi u ́$ , mas, além disso, ainda uma reidentificação dos extremos. De tal modo que também aquilo que corresponde ao imortal ou ao mortal sofre uma significativa transformação e passa, de facto, a ser outra coisa. Cf. infra nota 41.

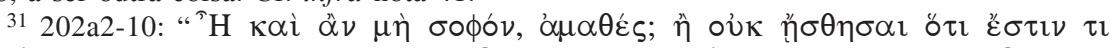

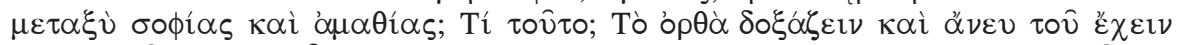

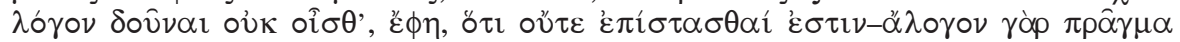

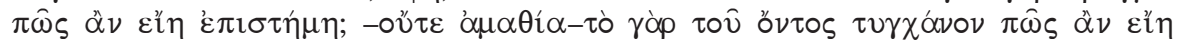

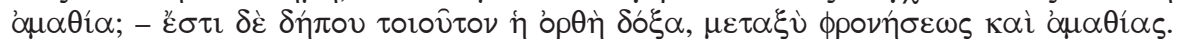
'A $\lambda \eta \theta \hat{\eta}, \hat{\eta} \nu \delta$ ' ' $\varepsilon \gamma \omega$, $\lambda \dot{\varepsilon} \gamma \varepsilon i \varsigma . "$

32 Convém ter presente, antes do mais, o campo semântico de $\delta$ o $\xi \alpha \zeta \varepsilon ı v$ e, em especial, os dois aspectos fundamentais que conformam o uso platónico do termo:1) Em primeiro lugar, $\delta \circ \xi \alpha \zeta \zeta \imath v$ designa aquilo que acontece quando deixa de se ter hesitação ou dúvida sobre $o$ que se passa ou a forma como as coisas são. Quer dizer: $\delta \circ \xi \alpha \zeta \varepsilon \iota v$ designa o assentamento ou a decisão "judicativa" - a fixação de um determinado "é assim", que dá por estabelecido ou adquirido que as coisas são deste ou daquele modo. $\Delta \circ \xi \hat{\alpha} \not \zeta \varepsilon ı$ v significa, portanto, tomar um determinado estado-de-coisas por verdadeiro, assumir uma determinada perspectiva como sendo adequada, fixar uma determinada versão das coisas. Percebe-se melhor aquilo que Platão designa por este termo justamente a partir do contraste, que aparece claramente

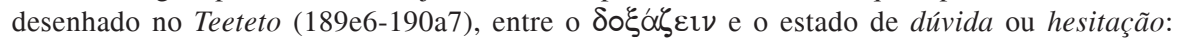
o $\delta \circ \xi \alpha \zeta \varepsilon \imath v$ é aquilo que passa a haver quando deixa de se estar em hesitação ou dúvida ( $\delta 1 \sigma \tau \alpha ́ \zeta \varepsilon \imath v)$. Isso não significa, claro está, que todo o $\delta o \xi a ́ \zeta \varepsilon ı v$ tenha de ser precedido por momentos de hesitação ou dúvida que vem ultrapassar: a maior parte das vezes não há nenhuma 
quer dizer, algo a que falta razão e que tem, nesse sentido, um carácter "não-

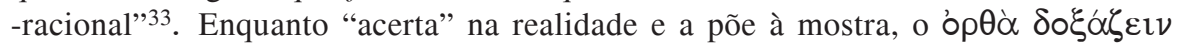
tem afinidade com o saber; enquanto, por outro lado, mantém a incapacidade de fundamentação ou justificação, ou seja, a incapacidade de se garantir a si mesmo como algo verdadeiro (e, nesse sentido, está exposto a incerteza), falta-lhe uma componente essencial e indispensável do saber. Daí o seu carácter intermédio. É isto que, num primeiro momento, é apresentado como instância intermédia entre o saber

hesitação ou dúvida precisamente porque já se está ("sempre" já se está) "instalado" num $\delta \circ \xi \alpha \zeta \zeta \varepsilon \imath \nu$ e, nesse sentido, numa $\delta \delta \xi \alpha$.

2) Em segundo lugar, o termo $\delta \circ \xi \alpha\lfloor\zeta \varepsilon \imath v$ pode ter uma conotação de imperfeição, que é ainda mais vincada no caso do substantivo $\delta \sigma \xi \alpha$. Nesse sentido, $\delta \circ \xi \alpha \zeta \varepsilon \imath v / \delta \sigma \xi \alpha$ designam uma forma de acesso marcada por fragilidade ou defeito (ou, como se pode dizer, pondo em evidência a ligação com o primeiro aspecto: trata-se de um assentamento, da adopção de uma determinada versão das coisas que se caracteriza por uma certa componente de defeito na forma como está constituída). Tal como Platão o concebe, essa fragilidade ou esse defeito pode ter diversas raízes (ou seja, a assunção de uma determinada versão das coisas pode ser defeituosa de diversas formas). E nos vários passos do Corpus Platonicum em que é feita

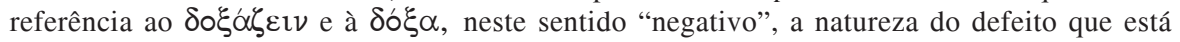
em causa não é sempre a mesma.

Em suma, o termo $\delta \circ \xi \alpha \dot{\alpha} \varepsilon ı v$ tanto pode exprimir apenas o primeiro aspecto (sem qualquer interferência do segundo), quanto, pelo contrário, acentuar este último. Mas, neste caso, põe-se o problema da identificação concreta de qual é o defeito que está propriamente em causa. É isso que se tem de esclarecer também aqui.

${ }^{33}$ Sócrates indica com toda a precisão que o termo $\delta \circ \xi \alpha \zeta \zeta \imath \iota$, tal como aqui o emprega, tem implicada a ideia de um defeito e que esse defeito consiste na falta da capacidade para o

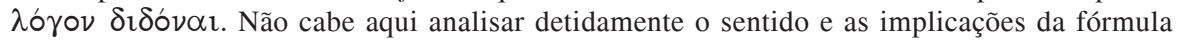

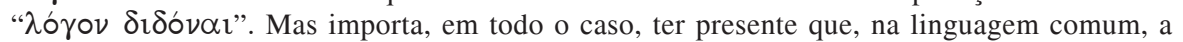
expressão dizia respeito à prestação de contas a que os magistrados atenienses estavam obrigados no termo dos respectivos mandatos. A expressão sugere, portanto, qualquer coisa como um voltar atrás, em que se é "chamado à pedra" e obrigado a uma explicação, a um exame, a uma justificação do que se fez. Trata-se, assim, no que diz respeito ao nosso olhar, de um voltar atrás (de uma interrupção do seu curso normal, que tende sempre a seguir adiante), para examinar e prestar contas do que a nossa própria perspectiva "fez" - quer dizer: de como está fundada, dos assentamentos em que embarca, das "decisões" que tomou, das determinações a que recorre, do respectivo valor e solidez, etc. De todo o modo, parece claro que a referência à incapacidade de "prestação de contas" ou de $\lambda$ ó ${ }^{\circ} \nu$ $\delta 1 \delta \delta v \alpha l$ aponta para a falta de fundamentação. Isso quer dizer, em primeiro lugar, que assentamentos ou decisões judicativas não foram adoptados por via de um processo de fundamentação e justificação, mas sim na ausência dele (como de facto acontece, vendo bem, com a esmagadora maioria dos assentamentos explícitos ou implícitos em que continuamente nos achamos embarcados). Mas significa também que, mesmo uma vez suscitada a questão da fundamentação, não se está em condições de levá-la a cabo ou de a produzir de forma cabal, válida e suficiente. Isto, por um lado. Por outro lado, ao mesmo tempo que acentua este aspecto, a noção de ó $\rho \theta \dot{\alpha} \delta o \xi \dot{\alpha} \zeta \varepsilon ı v$ aqui em causa vinca também um ponto muito importante: apesar do defeito referido, não se trata de assentamentos ou decisões judicativas que escondam aquilo a que respeitam, o distorçam, mascarem, afastem dele, atribuindo-lhe determinações que de facto não lhe pertencem. Trata-se, muito pelo contrário, de assentamentos ou decisões judicativas que acertam "em cheio", são correctas ou adequadas, fazem "ver as coisas como são". Numa palavra, trata- 
e a ignorância. Mas, no curso ulterior da exposição, isso é revisto - e o que acabamos

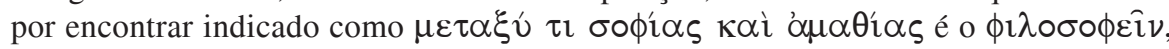
o fenómeno da procura enquanto tal, quer dizer, por um lado, o peculiar fenómeno que é a mobilização para (ou a tensão dirigida a) um saber que ainda falta mobilização ou tensão constituída de tal modo que se procura empenhadamente obtê-lo - e, por outro lado, a peculiar situação de acesso que é condição de possibilidade dessa tensão ou mobilização sc. da própria procura enquanto tal, situação essa que se caracteriza por implicar ao mesmo tempo um saber e um não saber aquilo que se procura - tê-lo já a descoberto e, todavia, ainda escondido, fora de alcance ${ }^{34}$.

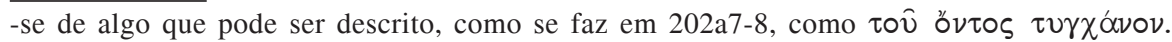

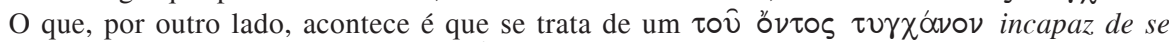
justificar e de se garantir como tal. É justamente este jogo de aspectos que se contrariam e limitam reciprocamente que permite a Sócrates caracterizar o o $\rho \theta \dot{\alpha} \delta \circ \xi \alpha \dot{\zeta} \varepsilon \iota v$, neste sentido,

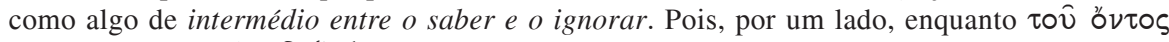

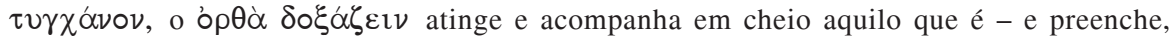
portanto, um aspecto fundamental da ideia de saber. Mas, por outro lado, enquanto lhe falta

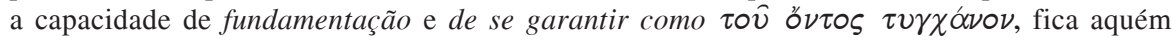
daquilo que é próprio do saber, tem uma falta de solidez e, como o texto diz, um carácter ¿ $\not \lambda \circ \gamma \circ \nu$, que o desqualificam como saber no sentido próprio e pleno do termo. Observe-se, finalmente, o seguinte. Em relação aos aspectos considerados na nota anterior, há de certo modo uma ambiguidade no uso da expressão ò $\rho \dot{\alpha} \delta \circ \xi \alpha \zeta \varepsilon \imath v$ neste passo. Se considerarmos a

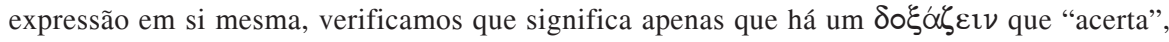
atinge ou acompanha aquilo que efectivamente se passa sc. o estado-de-coisas a que diz respeito. Isso parece não envolver em si mesmo nenhuma ideia de defeito, mas sim do contrário.

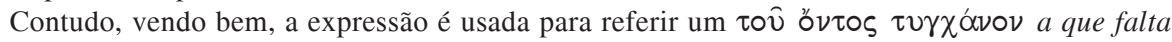
a capacidade de autojustificação ou o $\lambda \operatorname{có}_{0} \mathrm{v} \delta \mathrm{l} \delta$ óv $\alpha$ l. Nessa medida, tem um sentido claramente associado à ideia de defeito - de tal modo que também neste caso a noção de $\delta 6 \xi \alpha$ tem uma carga "negativa". Sobre todo este conjunto de questões relativas à noção de

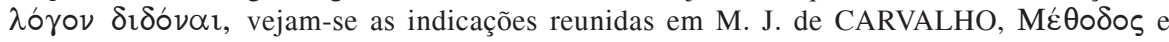
v $\pi \delta$ $\theta \varepsilon \sigma ı \varsigma$ - o problema do pressuposto na fundação platónica da filosofia, in: D. FERRER (ed.), Método e métodos do pensamento filosófico, Coimbra, Imprensa da Universidade, 2007, 9-69, em especial 30, nota 27.

34 Num segundo momento, o que é identificado como instância intermédia entre o saber

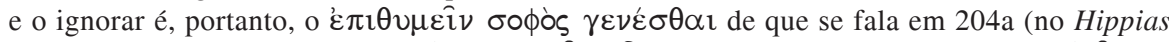

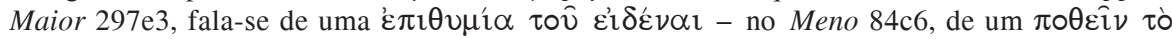
$\varepsilon^{\prime} \delta_{\varepsilon} \varepsilon \mathcal{V} \propto$ l). São vários os aspectos que convém acentuar a este respeito. Em primeiro lugar, importa ter clara noção de que não está em causa apenas o próprio acto de procura, mas também as características peculiares da situação de acesso que possibilita a procura enquanto tal. Esse é um ponto que ainda terá de ser visto um pouco mais em pormenor, mas que cumpre ter presente desde já. Como claramente se enuncia nos passos paralelos do Meno 80d5ss., 85dss., do Charmides 175c, do Euthydemus 275d-277c, do Lysis 218a e do Phaedrus 278d, e na própria explicação adiantada por Diotima, o problema está em que a procura enquanto tal não é possível nem numa situação de total desconhecimento ou ignorância, nem numa situação de conhecimento ou saberdo procurado, mas antes apenas numa situação a) diferente de qualquer uma destas e que, por outro lado, se caracteriza b) por diferir do conhecimento ou do saber em virtude da afinidade que tem com o desconhecimento ou a ignorância (ou seja, por 
Em terceiro lugar, perde-se o essencial daquilo que está em causa no discurso de Diotima, se se concebe o $\mu \varepsilon \tau \alpha \xi \hat{v}$ - o meio-termo ou a instância intermédia de que fala apenas como uma terceira possibilidade além dos extremos e que se situa, de alguma forma, entre eles - no modo como, por exemplo, se pode conceber que, sendo o preto e o branco opostos, o amarelo ou o vermelho constituem, relativamente

estar menos afastada da ignorância que a distância que separa dela o conhecimento ou o saber) e c) por diferir também do desconhecimento ou da ignorância em virtude da afinidade que tem com o conhecimento ou o saber (ou seja, por estar menos afastada do saber que a distância que vai deste à ignorância), de tal modo que d) a procura sc. a situação de acesso que lhe corresponde se situa algures numa posição intermédia entre o conhecimento ou o saber e o desconhecimento ou a ignorância. Ora, mesmo sem entrar numa análise um pouco mais detida da peculiaridade desta forma de acesso própria do $\phi 1 \lambda \circ \sigma \circ \phi \varepsilon i \hat{\nu}$, enquanto significa procura, etc., resulta claro o vivo contraste que há entre ela e o óp $\theta \dot{\alpha} \delta \circ \xi \alpha \zeta \varepsilon \imath v$ - ou seja, o vivo

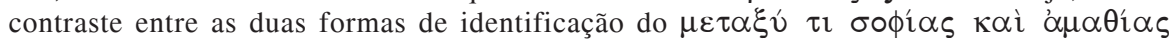
sucessivamente apresentadas no discurso de Sócrates/Diotima. Pois o ó $\theta \dot{\alpha} \delta$ o $\xi \alpha \zeta \varepsilon \imath v$ é,

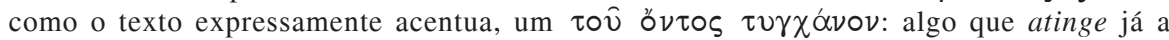
realidade a que diz respeito, a põe à mostra adequadamente e a acompanha. $\mathrm{O}$ defeito que o caracteriza não o afasta daquilo a que diz respeito, não faz que fique ainda aquém dele é compatível com uma plena coincidência ou adequação. Pelo contrário, a forma de defeito característica do $\phi \imath \lambda \circ \sigma \circ \phi \varepsilon i ̂ v$ ou da situação de acesso própria da procura implica que se esteja ainda aquém dessa coincidência com aquilo que é, ainda a caminho dela e longe dela.

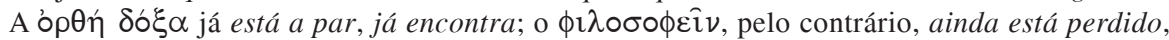
ainda vai só a caminho. Nesse sentido, a distância entre esta segunda modalidade de

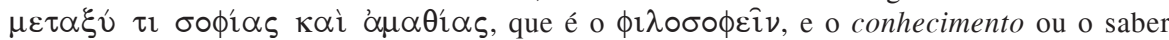

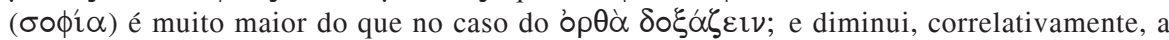
distância em relação ao outro extremo, quer dizer, à $\alpha \mu \alpha \theta i \alpha$ : ao desconhecimento ou à ignorância.

Sobre tudo isto duas observações. A primeira diz respeito a um ponto que não se pode desenvolver aqui, mas que é de registar para prevenir mal-entendidos. O facto de Platão, neste

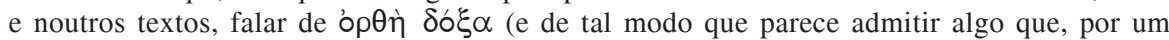

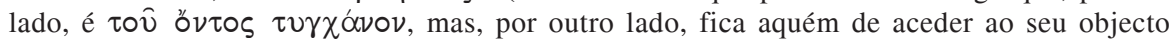
naquela forma que possibilitaria o $\lambda o ́ \gamma o v \delta 1 \delta o ́ v \alpha \imath$ ) não significa de modo nenhum que, em última análise, partilhe dos pressupostos em que se funda a concepção de algo assim. Mas este é um aspecto que, de todo o modo, não é preciso esclarecer aqui, pois o que aqui importa

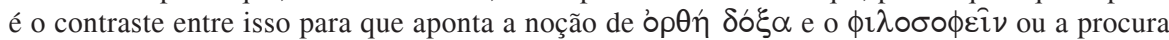
(sc. a situação de procura) que, num segundo momento, Diotima indica como equivalendo

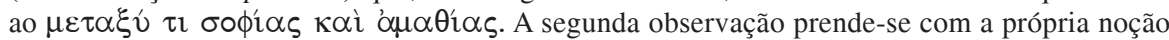
de $\phi \imath \lambda \circ \sigma \circ \phi \varepsilon \hat{\imath} \nu$. O cabal esclarecimento do que Platão diz neste passo requereria uma análise cuidada da origem desta expressão, dos seus desenvolvimentos, dos vários registos e das diversas acepções em que é usada, da conexão que têm entre si, etc. Tal análise permitiria

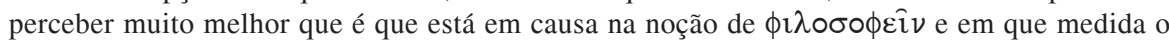
$\phi 1 \lambda \circ \sigma \circ \phi \varepsilon i \hat{\nu}$ constitui, de facto, algo de intermédio entre o saber e o ignorar. Mas como não cabe nos limites deste estudo, tem de se passar sem ela - na esperança de que os elementos aduzidos sejam, apesar de tudo, suficientes para captar o que se acha desenhado no discurso de Sócrates/Diotima. 
a eles, algo de intermédio ${ }^{35}$. Ao conceber-se assim, entende-se o $\mu \varepsilon \tau \alpha \xi u ́$ como tendo uma natureza do mesmo tipo da dos extremos entre os quais se situa e como se a identidade própria dessa instância intermédia tivesse, como a deles, um carácter autónomo (o carácter de uma "qualidade simples"), que em si mesma não envolve nenhuma conexão intrínseca com as determinações dos extremos entre os quais se situa. Ora, não é isso que Diotima tem em mente. Vendo bem, aquilo para que Diotima aponta é intermédio no sentido de ter uma constituição tal que reúne e mistura em si os extremos. Estes não se anulam reciprocamente, "contaminam-se" um ao outro deixam de ser plenamente a sua própria determinação, sem todavia a perderem inteiramente, entram em contacto, sem se neutralizarem - constituindo assim um terceiro que releva de ambos e é constitutivamente relativo a eles. Tal como Diotima o concebe, $\mu \varepsilon \tau \alpha \xi \hat{v}$ significa, portanto, algo misto: misto em relação aos opostos - e misto não no sentido de ter uma parte de um e uma parte de outro (como uma espécie de mosaico), mas no sentido de uma fusão dos opostos na mesma natureza (que tem algo dos dois, mas por tal sorte que o que tem de um está transformado pelo que também tem do outro, i. e. alienado de si mesmo no seu oposto $)^{36}$.

35 De sorte que a noção de instância intermédia corresponde apenas ao facto de não haver só os opostos em causa, mas também outras determinações que se caracterizam por distarem de qualquer um deles menos do que o intervalo que os separa. Nos próprios diálogos de Platão há numerosos passos onde $\mu \varepsilon \tau \alpha \xi u ́$ significa justamente algo dessa ordem, que não corresponde à noção desenhada na intervenção de Diotima. Mesmo onde não está usado em sentidos adverbiais comuns e envolve já traços de conceito filosófico, por vezes o termo $\mu \varepsilon \tau \alpha \xi u ́ v$ implica apenas a ideia de interposição - no espaço, numa sequência, etc. (v/, por exemplo, Theaetetus 147e9, 156d6, 182a5); noutros casos, tem associada a ideia de transição, de passagem entre os extremos (v/, por exemplo, Phaedo 71a12ss., Theaetetus 188a3, Parmenides 152c5); outras vezes está claramente determinado pela ideia de neutralidaderelativamente aos extremos (por não ser nem como um nem como o outro - veja-se, por exemplo, Lysis 217-218, 220d5, Gorgias 467e1ss., Respublica 583c1ss., 584e9, Theaetetus 154a2s., Parmenides 161d5ss., Phaedo 90a2ss.): também há passos onde está deixado em aberto de que modo o $\mu \varepsilon \tau \alpha \xi u ́$ ocupa uma posição entre os extremos (definindo-se que é mais $\mathrm{x}$ do que um extremo e menos y do que o outro, mas sem precisar como se produz essa instância intermédia - se autonomamente, se por participação dos próprios extremos, etc. - v/, por exemplo, Phaedo 89e5ss., Respublica 359a5s., 443d7, Leges 867a1, 878b6); finalmente, noutros passos, está claramente presente a ideia da constituição do $\mu \varepsilon \tau \alpha \xi u ́$ por qualquer coisa como um cruzamento dos extremos que medeia e a simultânea participação da determinação de ambos - assim, por exemplo, Euthydemus 306a, Timaeus 50d3, Leges 893e. Como se verá, alguns dos aspectos a que a noção aparece associada nesses passos (a ligação com a ideia de transição, o "excesso" em relação a um dos extremos e o "defeito" em relação ao outro, a ideia de "cruzamento") estão presentes na noção de $\mu \varepsilon \tau \alpha \xi u ́$ tal como aparece fixada no Symposium - mas isso de tal forma que esta os integra numa fixação mais "especificada" e mais precisa (juntando a ideia de transição, de excesso e de defeito, de cruzamento, etc., à concepção de uma determinada forma de conjunção dos extremos, que é aquela que aqui se tentará pôr em relevo).

${ }^{36}$ Onde aparece uma noção de $\mu \varepsilon \tau \alpha \xi u ́$ cuja forma corresponde inteiramente àquela que se acha desenhada no Symposium é no final do livro V da Respublica, em 475dss. Mas aí o $\mu \varepsilon \tau \alpha \xi u ́$ não aparece ligado ao fenómeno da procura (ou ao tipo de acesso "intermédio" que 
À primeira vista, tais formulações parecerão talvez obscuras. Mas podemos ganhar a pista do que significam a partir da forma como Diotima caracteriza a

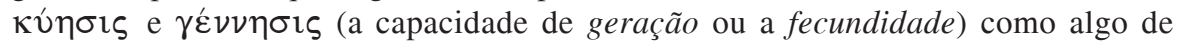
intermédio entre o mortal e o imortal. Tal como é apresentada no Symposium, a

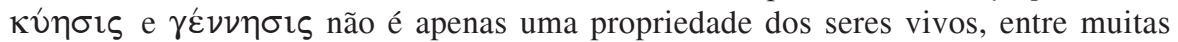
outras, antes corresponde a qualquer coisa como uma determinação fundamental, que cunha de raiz o modo-de-ser do que é vivo e o constitui em todos e cada um dos seus momentos. Vejamos um pouco melhor o que isto quer dizer.

Por um lado, é próprio de um ser vivo não estar absolutamente fechado na sua própria identidade, não se esgotar nela sc. no seu próprio acontecimento, antes "transbordar" de si próprio para outro(s), numa transmissão ou reprodução da vida - que deixa de algum modo a subsistir, num outro acontecer de si (no acontecimento do outro ser vivo que advém da transmissão), a própria identidade daquele que assim "extravasa" para lá de si, se reproduz - ou seja, produz para lá de si um outro si mesmo, tão "si mesmo" quanto o consente a própria fronteira da alteridade.

Por outro lado, vendo bem, não é só nessa passagem de si para outro, de indivíduo para indivíduo (e assim sempre de novo, numa cadeia de transmissão, em que a vida, a identidade dos seres vivos tende a perpetuar-se), que o modo-de-ser das realidades deste tipo se caracteriza por esta peculiar constituição, em si, de algo de outro, em que se faz continuar aquilo que se é para lá de si. Pois, como Diotima aponta, mesmo já no âmbito da existência de cada indivíduo vivo se verifica algo da mesma natureza. De sorte que a própria continuação ou subsistência do indivíduo

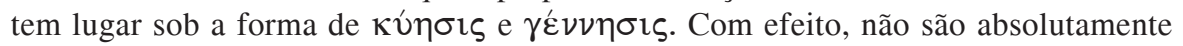
as mesmas realidades que formam um indivíduo desde o nascimento até à morte. Antes sucede que cada indivíduo está sujeito a uma contínua aniquilação da realidade que era e só sobrevive e mantém a sua identidade justamente por um contínuo re-fazer-se: por uma contínua reprodução de si que assegura a passagem de instante

possibilita a procura), mas antes a uma modalidade de acesso, também intermédia entre o saber e o ignorar, que Platão designa como $\delta \delta$ $\xi \alpha$, atribuindo-lhe, porém, um defeito muito diferente

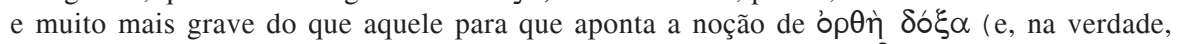

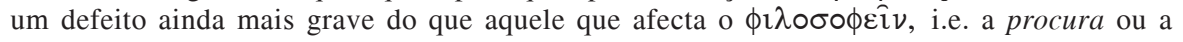
situação de procura). Não pertencendo aqui analisá-lo, basta referir que, tal como o $\phi 1 \lambda \circ \sigma \circ \phi \varepsilon i ̂ v$ para que Diotima aponta, também esse algo-de-intermédio-entre-o-saber-e-o-ignorar que está em causa no final do livro V da Respublica tem uma constituição tal que não apenas se situa entre o saber e o ignorar, mas, além disso, é feito de saber e de ignorar, cruzados um com o outro. Veja-se infra, $\S 4$, em especial a nota 74 . De qualquer modo, o que de momento importa é ter clara noção de que o uso da noção de $\mu \varepsilon \tau \alpha \xi u ́ v$ no corpus platonicum não é absolutamente unívoco - como acontece, aliás, com a maior parte das noções usadas no corpus. Pois constitui precisamente uma característica dele a ausência de qualquer terminologia fixa e a circunstância de termos que em dados passos são usados para referir um determinado fenómeno, laboriosamente circunscrito para o demarcar de outros afins com que o próprio uso desse termo o pode fazer confundir, noutros passos aparecerem precisamente usados nessas outras acepções. Uma vez que não se pode entrar aqui numa mais aturada discussão dos sentidos e implicações do conceito de $\mu \varepsilon \tau \alpha \xi \dot{v}$, antes de Platão, entre os seus contemporâneos e no corpus platonicum, esboça-se um conspecto bibliográfico no Apêndice II. 
para instante. Nada num ser vivo, por exemplo em nós (nem os cabelos, nem as carnes, nem os ossos, nem as opiniões, nem os desejos, nem os prazeres, nem as dores, os medos, etc.) está constituído de uma vez por todas, numa aquisição definitiva. Não. A cada instante o ser vivo está sujeito a um completo esvaimento ou perda do que era ${ }^{37}$. E só sobrevive justamente porque está sempre já constituído contra essa perda - de forma a contrariá-la. De tal modo que continuamente faz substituir aquilo que assim continuamente se perde e consegue transmitir a sua identidade para as novas realidades nos novos instantes (ou nos novos planos temporais) em que sempre de novo passa a ter-se ${ }^{38}$. Por outras palavras, só sobrevive, só se mantém o mesmo (o mesmo na forma que lhe é possível: o mesmo a ser sempre outra coisa), porque em cada instante não se esgota em ser aquilo que nesse instante é, antes tem uma natureza tal que, a partir do que de cada vez o constitui, está sempre já na tensão para a reprodução de si mesmo noutras realidades substitutivas daquelas que de momento o constituem, mas são insusceptíveis de continuar a fazê-lo.

Mas não é só em relação ao corpo que isto se passa. O mesmo se verifica

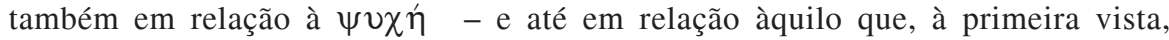
pareceria mais estável e permanente. Pois, prossegue Diotima, algo de equivalente se passa também a respeito do saber - das próprias ciências ou dos próprios

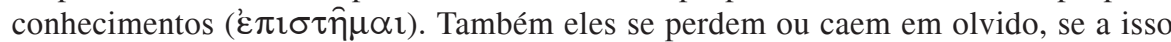
não obviar o $\mu \varepsilon \lambda \varepsilon \tau \hat{\alpha} \nu$ (a aplicação ou o exercício), que renova a retenção ou a memória, quer dizer, cria uma nova retenção ou uma nova memória em vez daquela que anteriormente se tinha - numa constante re-produção do próprio saber. Quer dizer: também neste âmbito a saída, a partida ou a perda ( ou seja o escondimento, o esquecimento ou olvido ( $\lambda \hat{\eta} \theta \eta)$ - é compensada por um movimento em sentido contrário. Esse movimento retira da memória que em dado momento havia (mas logo é arrastada na corrente do tempo e do esquecimento e deixa

${ }^{37}$ É justamente isso que significa estar na temporalidade: ter o plano de realidade em que se é pura e simplesmente desalojado, erradicado, aniquilado, com o advento de cada novo instante e a precipitação daquele que era em já-não ser. E isto de tal modo que essa precipitação ou aniquilação se produz a cada instante e, por exemplo, a mão que escreveu o princípio desta frase já está agora inteiramente anulada - tão anulada como o que quer que seja que houve ou aconteceu há milhares de anos.

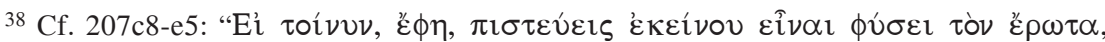

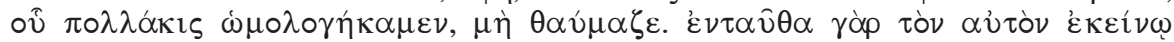

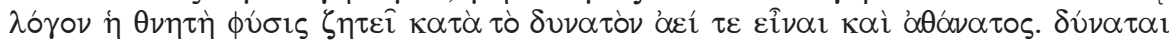

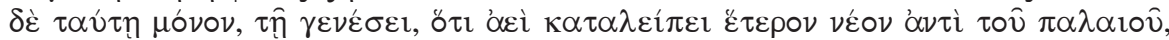

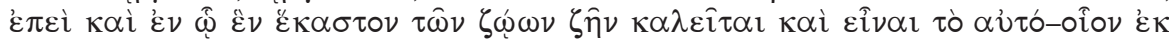

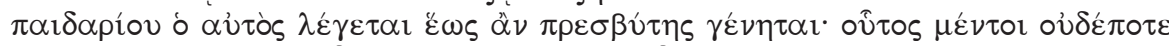

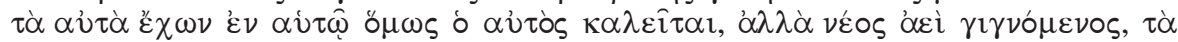

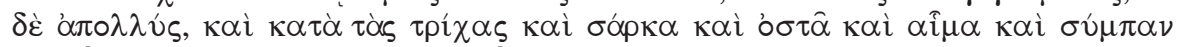

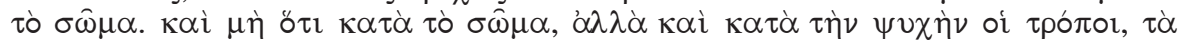

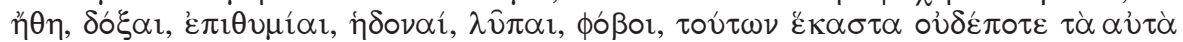

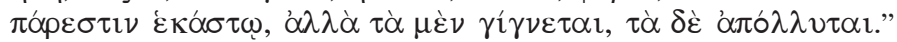


de ser) uma outra memória que, por sua vez, também é arrastada na corrente do tempo e do esquecimento, deixando de ser, mas não sem se ver renovada por um nova iniciativa de renovação - e assim sucessivamente. Assim, só por um exercício ou uma actividade de reprodução de si cada $\dot{\varepsilon} \pi \iota \tau \eta \dot{\mu \eta}$ ou cada conhecimento consegue atravessar, contra a corrente, o fluxo do tempo e o seu efeito de apagamento. A subsistência do saber não é, assim, uma pura e simples permanência, mas sempre qualquer coisa como um contra-apagamento, por transmissão contra a corrente aniquiladora do tempo. É precisamente isso que está em causa na noção de $\mu \varepsilon \lambda \varepsilon \tau \hat{\alpha} \nu$ e de $\mu \varepsilon \lambda \dot{\varepsilon} \tau \eta$, tal como é usada por Diotima para exprimir esta re-posiçãol re-novação do próprio saber, sem a qual também ele se perde - e que constitui, assim, a forma da sua subsistência ${ }^{39}$.

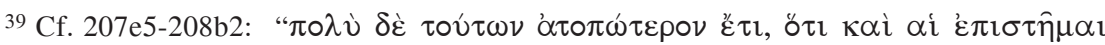

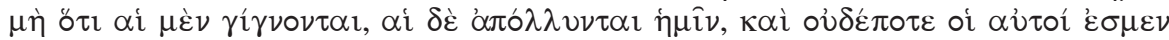

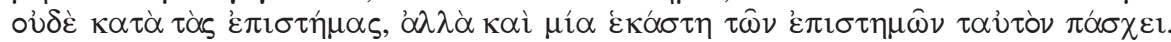

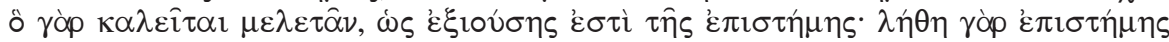

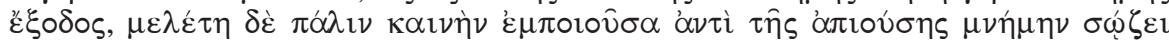

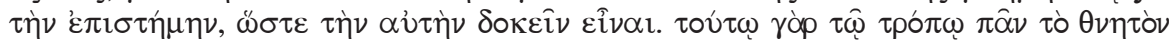

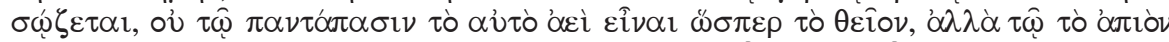

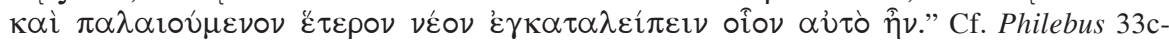
34b, Phaedo 75d, Leges 732b. Também este ponto levanta vários problemas. Um deles diz

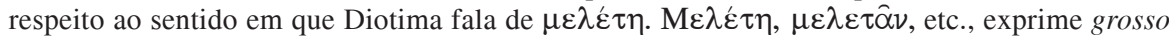
modo a ideia de qualquer coisa como uma aplicação ou um exercício, um esforço - um ocupar-se com, tratar e cuidar de, etc. Parece claro que Diotima está a aludir à experiência comum de que a prolongada ausência de contacto com os próprios conhecimentos que se têm, a prolongada ausência de exercício deles (como, por exemplo, a respeito de uma língua) traz consigo isso que Diotima exprime ao falar de ع̌ $\xi_{0} \delta \circ \varsigma$ e de $\lambda \eta \forall \eta$. Ou seja, a ausência de $\mu \varepsilon \lambda \dot{\varepsilon} \tau \eta$ (do exercício que, de algum modo, os reaviva e renova - a ausência daquilo a que comummente chamamos, por exemplo, a "prática" de uma língua) como que dissolve, apaga esses conhecimentos, produzindo uma espécie de re-encobrimento (re-escondimento) daquilo a que dizem respeito. Mas, sendo assim, por outro lado, parece também claro que Diotima não tem em mente apenas certo tipo de conhecimentos, nem tampouco apenas uma reactivação que ocorra só de quando em quando (e que de cada vez - por exemplo, no caso de uma língua só tome em mãos uma parte dos conhecimentos que se têm). Não, segundo tudo indica, Diotima tem em mente algo que se passa continuamente (quer dizer, de instante a instante) e, por outro lado, não apenas uma reactivação ou uma renovação de alguns conhecimentos, mas uma renovação ou transferência da totalidade do património cognoscitivo que se tem. Numa palavra, a perspectiva desenhada por Diotima faz valer para todo o conhecimento, seja ele qual for, aquilo que Samuel Butler (Prose Observations, ed. H. de Quehen, Oxford, Clarendon Press, 1979, 15) diz a respeito de uma forma específica de conhecimento (cita-se mantendo a grafia e a pontuação originais): "A great Deale of Lerning is, like a great House, very chargeable to be kept in Repaire (....)". Com a diferença de que aquilo para que Diotima aponta equivale a nada mais, nada menos do que constantes “obras totais”. Ora, não só há alguma dificuldade em entender como possa produzir-se essa transmissão ou transferência: essa "obra”total (é justamente esse o problema que se levanta quando a noção confusa de persistência dos conhecimentos - a noção de memória, etc. - é confrontada com uma aguda consciência de que a temporalidade significa, em cada novo instante, pura e simplesmente a total anulação 
do que era), mas, além disso, também não resulta nada claro como é que essa transmissão ou transferência pode ser operada por uma $\mu \varepsilon \lambda \dot{\varepsilon} \tau \eta$. Pois, em sentido próprio, $\mu \varepsilon \lambda \dot{\varepsilon} \tau \eta$ significa um ocupar-se expressamente com, um exercitar, 153b), e não só não temos consciência de nada disso (de um "ocupação" total com os nossos conhecimentos, de um exercício total, tendo lugar de instante a instante), mas inclusivamente parece claro que a nossa capacidade de exercício ou aplicação tem como que uma lotação limitada - corresponde, por assim dizer, a um "cursor" que, para coincidir com umas coisas tem de deixar de coincidir com outras (de tal modo que, no tempo em que nos ocupamos com umas coisas, forçosamente temos de deixar inatendidas todas as demais). Isso põe o problema de saber qual é exactamente a natureza do acontecimento de transferência ou de renovação que está implicado no facto de haver "continuidade" do património cognoscitivo. Este problema não chega sequer a ser atacado (e muito menos chega a ser resolvido) na intervenção de Diotima. Mas o ponto decisivo que Diotima procura vincar é, de todo o modo, que não se trata de uma pura permanência, sem mais nada (assegurada como que por inércia - como se o simples facto de um conhecimento estar adquirido produzisse, só por si, qualquer coisa como uma inscrição permanente dele). Não. Também neste caso a permanência resulta de uma "travessia" ou transmissão oposta ao efeito de anulação do tempo: uma travessia ou transmissão que rompe o modo como a posse dos conhecimentos está fechada no instante em que de cada vez ocorre - uma travessia ou transmissão que opera como que um salto de re-constituição ou transferência para cada novo tempo. De sorte que também os conhecimentos só duram, só permanecem, na medida em que continuamente se reconstituem ou renovam. Quanto à $\mu \varepsilon \lambda \dot{\varepsilon} \tau \eta$, parece claro que a preocupação

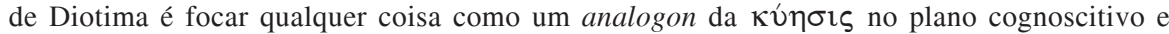

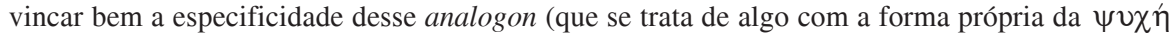
e não a do $\sigma \hat{\omega} \mu \alpha$, etc.). Podem ser várias as razões por que lhe chama $\mu \varepsilon \lambda \dot{\varepsilon} \tau \eta$ - além daquela que tem que ver com a já referida alusão à experiência comum de conhecimentos que se perdem se não forem exercitados. Uma das razões por que Diotima fala de $\mu \varepsilon \lambda \varepsilon \tau \eta$ pode ser, por exemplo, a tradição pré-platónica de oposição entre $\phi v ́ \sigma i \varsigma$ e $\mu \varepsilon \lambda \varepsilon \dot{\varepsilon} \tau \eta$, que vinca a ideia de que há conhecimentos, capacidades, etc., que não se constituem "espontaneamente", "por natureza" ( $\phi \hat{\sigma} \sigma \varepsilon \mathrm{l})$ antes têm de ser adquiridos, apropriados. Nesse caso, o que estaria em causa neste uso da noção de $\mu \varepsilon \lambda \varepsilon \dot{\varepsilon} \tau \eta$ seria a componente da "apropriação" ou a ideia de que todos os conhecimentos têm de ser continuamente reapropriados num acontecimento de transferência - e a noção de $\mu \varepsilon \lambda \dot{\varepsilon} \tau \eta$ estaria dissociada da ideia de algo que ocorre por ocupação expressa: traduziria um silencioso esforço da própria $\psi v \chi \eta ்$ transferindo-se ou reproduzindo-se como que a "nadar" contra a corrente em relação ao tempo, etc.). Mas também pode acontecer que J. Brunschwig tenha razão na sugestão que fez (op. cit. infra) e que Diotima efectivamente esteja a fazer aqui um jogo de palavras, como os do Cratylus, e

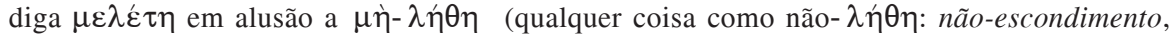
não-olvido - ou, como também se poderá dizer, des-olvidação). De resto, estas diversas possibilidades não são exclusivas umas das outras. Sobre $\mu \varepsilon \lambda \varepsilon \tau \tilde{\alpha} \nu, \mu \varepsilon \lambda \dot{\varepsilon} \tau \eta$, etc., veja-se, por exemplo, A. HUG, Platons Symposion, Leipzig, Teubner, 1876, 145, J. H. H. SCHMIDT, Synonymik der griechischen Sprache, vol. II, Leipzig, Teubner, 1878, 631, J. ADAM (ed.), The Republic of Plato, vol. II, Cambridge, University Press, 1902, ad 488d 28, P. SHOREY,

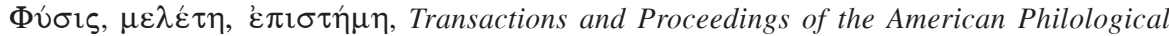
Association 40 (1909), 185-201 (=IDEM, Selected Papers, vol. I, N.Y., Garland,1980, 1-18.), C. P. GUNNING, De sophistis Graeciae praeceptoribus, Amsterdam, Kruyt, 1915, 132ss., W. ALY, Formprobleme der frühen griechischen Prosa, Leipzig, Dietrich, 1929, 53s., R. G. BURY, The Symposium of Plato, Cambridge, Heffer, 1932², ad 172a, U. GALLI (ed.), Il simposio, Torino, Chiantiore, 1935, ad 172a, P. BOYANCÉ, Le culte des Muses chez les philosophes grecs, Paris, de Boccard, 1936, W. ARTELT, Studien zur Geschichte der Begriffe „Heilmittel” 
A implicação é clara: tudo no ser vivo, desde as diferentes componentes do seu corpo até àquilo que sabe (e à própria constituição do que podemos descrever como a sua lucidez), está intrinsecamente afectado pela corrosão do tempo e só se

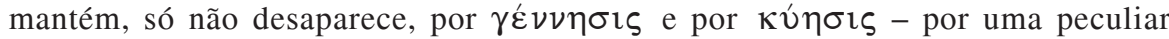
fecundidade ou por um peculiar poder de geração mediante o qual não se esgota em si, não se queda em si, antes se transmite, se transfere, se re-produz e - nessa transmissão ou transferência - contra-anula a anulação do tempo. De sorte que a reprodução no sentido mais estrito (a transferência da vida de um indivíduo para outro, a constituição de novos seres vivos a partir de outros que já são) representa apenas mais uma forma de se dar a transmissão e mais um elo na cadeia de

und "Gift": Urzeit, Homer, Corpus Hippocraticum, Leipzig, Bart, 1937, reed. Darmstadt, Wissenschaftliche Buchgesellschaft, 1968, 62, W. NESTLE, Vom Mythos zum Logos. Die Selbstentfaltung des griechischen Denkens von Homer bis auf die Sophistik und Sokrates, Stuttgart, Kröner, $1942^{2}$, F. HEINIMANN, Nomos und Physis. Herkunft und Bedeutung einer Antithese im Griechischen Denken des 5. Jahrhunderts, Basel, Reinhardt, 1945, reed. Darmstadt, Wissenschaftliche Buchgesellschaft, 1987, 100s., 168, C. PICARD, Nouvelles remarques sur 1'apologue dit de Prodicos, Revue Archéologique 42 (1953), 10-41, K. RIES, Isokrates und Platon im Ringen um die Philosophia, Diss., München, 1959, 117s., J.-P. VERNANT, Aspects mythiques de la mémoire, Journal de psychologie 56 (1959), 1-29 (=IDEM/P. VIDAL-NAQUET, La Grèce ancienne 2 L'espace et le temps, Paris, Seuil, 1991, 15-46), J.-P. VERNANT, Le fleuve Amélès et la Mélétè Thanatou, Revue philosophique de la France et de l'Étranger 150 (1960), 163-179 (=IDEM/P. VIDAL-NAQUET, La Grèce ancienne 2 L'espace et le temps, Paris, Seuil, 1991, 165-183), P. RABBOW, Paidagogia. Die Grundlegung der abendländischen Erziehungskunst in der Sokratik, Göttingen, Vandenhoeck \& Ruprecht, 1960, 109s., 244s., N. van BROCK, Recherches sur le vocabulaire médical du grec ancien. Soins et guérison, Paris, Klincksieck, 1961, 236ss., em especial 239s., J. BRUNSCHWIG, Correspondance. Sur Amélès et Mélétè, Revue philosophique de la France et de l'Étranger 153 (1963), 267-268, M. O'BRIEN, The Socratic Paradoxes and the Greek Mind, Chapel Hill, The University of North Carolina Press, 1967, 144ss., C. DIANO, Saggezza e poetiche degli antichi, Venezia, Neri Pozza, 1968, 229s., J. KUBE, TEXNH und APETH. Sophistisches und platonisches Tugendwissen, Berlin, de Gruyter, 1969, 15, 49s., 79s., F. HIERONYMUS, ME 1970, J. KAMBITSIS, L'Antiope d'Euripide. Édition commentée des fragments, Athènes, s.n., 1972, 46s., J. JOUANNA, Hippocrate. Pour une archéologie de l'École de Cnide, Paris, Les Belles Lettres, 1974, 224, C. W. MÜLLER, Die Kurzdialoge der Appendix Platonica. Philologische Beiträge zur nachplatonischen Sophistik, München, Fink, 1975, 220ss., em especial 224ss., P. HADOT, Exercices spirituels et philosophie antique, Paris, Études augustiniennes, 1981, 18ss., M. SIMONDON, La mémoire et l'oubli dans la pensée grecque jusqu'à la fin du Ve siècle avant J.-C.: psychologie archaïque, mythes et doctrines, Paris, Les Belles Lettres, 1982, 104s., D. MONTET, Les traits de l'être. Essai sur l'ontologie platonicienne, Grenoble, J. Millon, 1990, 100ss., C. J. ROWE (ed.), Plato Phaedo, Cambridge, Cambridge University Press, 1993, ad 67d8, S. R. SLINGS (ed.), Plato Clitophon, Cambridge, Cambridge University Press, 1999, 106ss., ad 410b8-c1, M. FOUCAULT, L'herméneutique du sujet, Cours au Collège de France, 1981-1982, Paris, Gallimard/Seuil, 2001, 10ss., 81s., 338s., 406, 435ss., 440s, 444, M. CIVILETTI, «Meléte»: analisi semantica e definizione di un genere, in: L. CALBOLI MONTEFUSCO (ed.), Papers on Rhetoric, vol. 4, Roma, Herder Editrice, 2002, 61-87. 
transmissão - mais uma modalidade ou mais um elo na cadeia deste ser-na-transmissão, na reprodução-de-si, que sempre já e a cada instante faz a realidade própria dos seres vivos ${ }^{40}$.

O que caracteriza o $\alpha \theta \alpha ́ \alpha \nu \alpha o \nu$, o imortal na sua plenitude, é a definitiva e integral manutenção da própria identidade em todo o tempo. Ou melhor, o que caracteriza o imortal é a completa subtracção a qualquer temporalidade - à contínua aniquilação do que era e ao efeito de contínua supressão da identidade que está implicado no próprio tempo. O que caracteriza o seu oposto, o $\theta \nu \eta \tau o ́ v$, a mortalidade pura e simples, é a total incapacidade de fazer persistir a identidade que se tem (de tal modo que esta se desvanece inteiramente - pura e simplesmente acaba). Neste sentido, mortal será aquilo que se esgota num instante, o ser que logo se perde, sem nada (absolutamente nada) que contrarie essa integral perda. Mortal é esse ser fechado num instante, que é em total evanescência ${ }^{41}$. Mas o que caracteriza o

40 Também aqui há um aspecto que não resulta inteiramente claro a partir das palavras de Diotima. Aquilo que faz que a subsistência de uma qualquer realidade só possa ter lugar por $\gamma \varepsilon \dot{\varepsilon} \nu \eta\rceil \zeta \zeta$ (por transferência ou reprodução de si) não se aplica apenas aos seres vivos em sentido estrito, mas sim a tudo quanto de algum modo atravessa o tempo ou tem algum grau de subsistência (e, em particular, uma subsistência marcada por identidade diacrónica). Em última análise, na perspectiva desenhada por Diotima, toda a subsistência no tempo implica alguma componente de transmissão e reprodução de si-e, nesse sentido, alguma $\gamma \hat{\varepsilon} \nu \nu \eta \sigma \iota \zeta$. Ora, isso significa um traço de afinidade e continuidade de modo-de-ser entre todos os entes que permanecem no tempo - sejam eles vivos (na acepção estrita e habitual do termo) ou não. Nesse sentido, não é inteiramente de excluir que a perspectiva desenhada por Diotima tenha que ver com uma modificação do reconhecimento daquilo que costumamos compreender como não-vivo. Ou seja, não é inteiramente de excluir que Diotima esteja a propor uma compreensão alargada do conceito de vida, eventualmente ligada à concepção do próprio todo da realidade como um ser vivo de que tudo faz parte, etc. Mas, por outro lado, também parece inegável que os seres vivos em sentido estrito (aqueles que se distinguem, além do mais, pelo facto de não se re-produzirem apenas em identidade diacrónica no âmbito da sua própria individualidade, mas, além disso, também se reproduzirem noutros indivíduos, etc.) são mais plenamente $\gamma \dot{\varepsilon} \nu \nu \eta \sigma ı \varsigma$ (correspondem muito mais àquilo que Diotima descreve) do que tudo o resto. Ora, tudo isto suscita um conjunto de questões, entre as quais a de saber se a própria forma de $\gamma \dot{\varepsilon} \nu \nu \eta \sigma \iota \zeta$ ou reprodução de si que assegura a continuidade ou a subsistência no caso de um ser vivo em sentido estrito (e que está acompanhada pela possibilidade de reprodução de si noutro indivíduo, etc.) tem a mesma natureza que a reprodução de si que também ocorre na total ausência desta última possibilidade - ou se, pelo contrário, é diferente. Acontece, porém, que, se não se está em erro, o discurso de Sócrates/Diotima se limita, por assim dizer, a "levantar a lebre" e acaba por deixar todos estes problemas em aberto.

41 Como se vê, a passagem de uma primeira identificação para uma segunda não diz respeito apenas ao $\mu \varepsilon \tau \alpha \xi u ́$ entre o mortal e o imortal - como se os extremos em causa se mantivessem os mesmos e apenas mudasse aquilo que é concebido como instância intermédia entre eles. De facto, muda também a própria identificação dos extremos. Pois, no primeiro momento, ao "imortal" correspondia a categoria dos deuses, enquanto o termo "mortal" era entendido na acepção em que designa os mortais, por oposição aos deuses, ou seja, os humanos. Nesta outra perspectiva, pelo contrário, as noções de mortal e de imortal são entendidas de tal modo que designam diferentes formas de constituição da identidade na sua 
fenómeno da vida, tal como Diotima o apresenta, é outra coisa. Por um lado, as identidades que nela estão em jogo não se mantêm integralmente, numa pura subsistência de si, antes sofrem qualquer coisa como um contínuo desaparecimento, uma contínua perda, evanescência. Mas, por outro lado, também não desaparecem pura e simplesmente, num total desvanecimento - antes se re-produzem, deixando sempre em seu lugar algo de outro, sim, mas que tem a determinação de ser, o mais que isso é possível, um segundo elas próprias - uma persistência delas próprias no diferente. E isto de tal modo que cada momento da vida de um ser-vivo nunca é absolutamente só o si-próprio do que é nesse momento, não se esgota inteiramente em si (no si do que está a ser): é sempre já também a tensão desse repor-se, dessa reprodução-de-si, no próprio ser-vivo e na sua descendência - e tem a sua própria identidade sempre já marcada por essa tensão de passagem ou transmissão de si a algo de outro ${ }^{42}$.

É a este peculiar modo-de-ser - ser na forma de "corrida de estafetas" (de estafetas que geram estafetas que geram estafetas...) e da contínua passagem do "testemunho" de si, é a este modo-de-ser contínua e integralmente feito da passagem

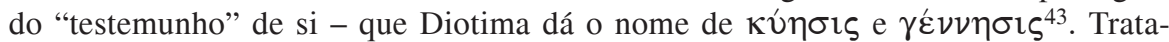
-se de um modo-de-ser radicalmente diferente do modo-de-ser daquilo que tem sempre assegurada a plena persistência da sua identidade, numa integral e indestrutível coincidência consigo. Mas, por outro lado, também se trata de um modo-de-ser radicalmente diferente do daquilo cuja identidade pura e simplesmente "morre" - é e, depois, deixa totalmente de ser (ou melhor: é instantaneamente, sempre já a deixar de ser). A diferença não é uma mera diferença de duração de realidades que, em si mesmas, no modo como estão constituídas, nada tenham de intrinsecamente diferente. Não: a diferença diz respeito ao modo como as diversas

relação com a alteridade ou alteração inerentes ao tempo. Daí resulta, por exemplo, que o humano, que na óptica da primeira identificação do $\mu \varepsilon \tau \alpha \xi \hat{v}$ entre o mortal e o imortal correspondia a um extremo, nesta outra passa a ter o carácter de uma instância intermédia.

${ }^{42}$ De tal modo que a sua permanência não resulta de uma identidade imperturbada, não é pura persistência do mesmo na absoluta mesmidade de si, antes é constituída por qualquer coisa como um analogon do $\mu \varepsilon \lambda \varepsilon \tau \hat{\alpha} \nu$ (de qualquer coisa como uma aplicação, um exercitar-se ou ocupar-se, uma actividade de renovação) - aplicação, exercício ou actividade de renovação sem os quais, como diz Diotima, o próprio conhecimento é levado e dissolvido na corrente do esquecimento. Ou seja, a própria identidade resulta de qualquer coisa como um exercício ou actividade de renovação na contracorrente do tempo, transpondo ou transportando a identidade contra ela. Mas isto de tal forma que o que assim consegue ser preservado (a forma de identidade que há nestas circunstâncias) não é verdadeiramente $o$ mesmo, no sentido forte e pleno do termo, antes algo multiplamente alterado ou contaminado pela alteridade e diversidade de todos e cada um dos momentos do tempo assim atravessado em contracorrente. A identidade consegue contrariar a corrente da alteridade, mas não sem ser modificada e contaminada por ela.

${ }^{43}$ A comparação com a corrida de estafetas não aparece no próprio Symposium, mas está traçada por Platão nas Leges $776 \mathrm{~b} 2-4$, onde se fala justamente da transmissão da vida na

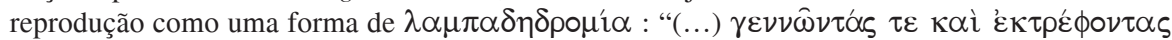

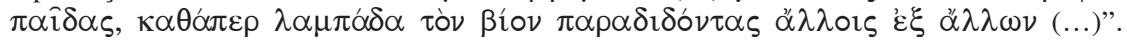


realidades em causa são si próprias - num caso de tal forma que a identidade é em si mesma imperecível, no outro caso de tal forma que essa identidade não tem condições para se manter, no terceiro caso, finalmente, de tal forma que a identidade não é imperecível, está sujeita a desaparecimento, mas, por outro lado, também não desaparece pura e simplesmente, antes resiste ao desaparecimento, em virtude da transmissão, da reprodução de si, de que é capaz e a que está constitutivamente sempre já votada - que está sempre já a $\operatorname{ser}^{44}$.

Em suma, o imperecível difere sempre já do modo-de-ser daquilo que perece (não difere só por um acréscimo de duração) e o que é no modo "transitivo" próprio dos seres vivos difere sempre já, pelo seu modo-de-ser, dos outros dois. Mas, por outro lado, se há uma tal irredutibilidade entre estas três formas de realidade, isso não impede que a terceira reúna de algum modo em si aquilo que é próprio das outras duas. Assim, se difere (e muito) do modo-de-ser correspondente à imortalidade (se as identidades que comporta estão sujeitas a uma contínua perda ou esvaimento), a verdade é que também comporta qualquer coisa de uma permanência perpétua. $\mathrm{E}$ se, por isto (porque se caracteriza por este ficar sempre), difere (e muito) do modo-de-ser correspondente à pura e simples mortalidade, a verdade é que não deixa de estar sujeita a um contínuo evanescimento ou desaparecimento, a uma contínua substituição de identidades que se perdem de forma absolutamente irrecuperável ${ }^{45}$. Constitui de algum modo uma imortalidade, sim, mas uma imortalidade precária, na não perfeita identidade: na diferença - na morte daquilo que de cada vez a constitui. É qualquer coisa, então, em que a imortalidade não é de forma absoluta (em si mesma), mas no seu oposto (na mortalidade, "contaminada" por ela, sujeita a ela, e a ter de ocorrer no modo dela). Inversamente, constitui também uma mortalidade, mas uma mortalidade que também não o é deforma absoluta, mas sim modificada no sentido do seu oposto (no sentido da imortalidade, "contaminada" por ela, transformada de modo a converter-se na referida forma precária de imortalidade). O que permite a Diotima, numa formulação que concisamente traduz tudo isto, caracterizar este $\mu \varepsilon \tau \alpha \xi v$ como sendo o imortal no mortal (a imortalidade

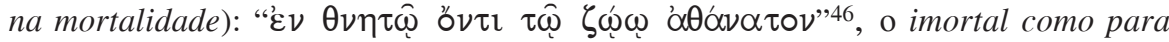

${ }^{44}$ E isto de tal modo que cada momento daquilo que é no modo-de-ser da kúnois e $\gamma \varepsilon \dot{\varepsilon} \nu \nu \eta \sigma \iota \varsigma$ é já feito - totalmente feito - de transmissão de si. Trata-se de qualquer coisa como um ser-em-transmissão. E nada, absolutamente nada, naquilo que possui o modo-de-ser da

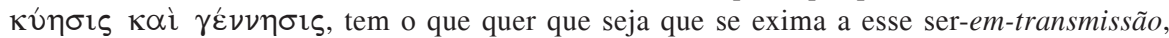
que o interrompa ou que, mesmo que só muito brevemente, difira dele. Cada momento daquilo que é desta maneira é sempre já a receber-se e sempre já a passar-se - e por tal forma que o próprio receber-se é já o passar-se: inclui já em si o pôr-se (ou transmitir-se) além de si.

${ }^{45}$ De sorte que a subsistência de cada vez alcançada é sempre de novo reposta em causa por esvaimento ou perda. A subsistência nunca está adquirida. Fica sempre outra vez por assegurar e tem sempre de novo de ser reassegurada por nova transmissão ou reprodução.

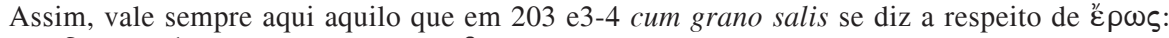

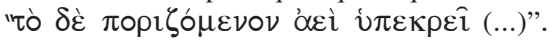

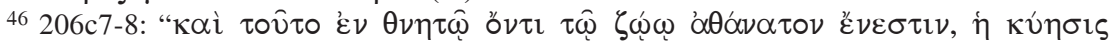

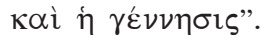




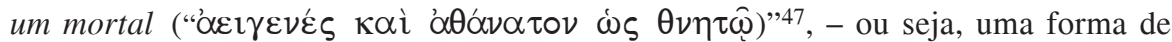

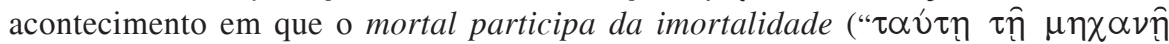

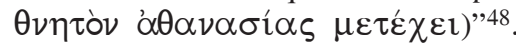

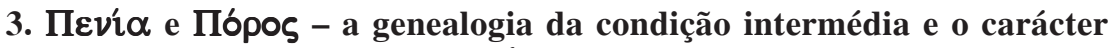 intrinsecamente orientado do $\mu \varepsilon \tau \alpha \xi v$}

Tudo isto põe-nos na pista que permite compreender a genealogia exposta em

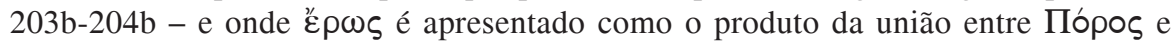
Пєví $\alpha$. Em primeiro lugar, o que Diotima apresenta como resultando desta união são precisamente todas as instâncias intermédias referidas. É por ter nascido de

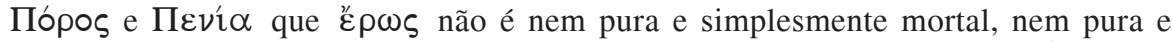
simplesmente imortal, antes conjuga a imortalidade e a mortalidade ${ }^{49}$. É por ter

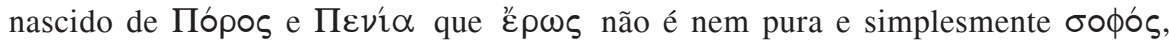
nem pura e simplesmente $\alpha \mu \alpha \theta \eta \dot{\zeta}$, antes conjuga a $\sigma o \phi^{\prime} \alpha$ e a $\alpha \mu \alpha \theta^{\prime} i \alpha$, o saber e

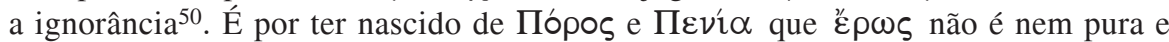

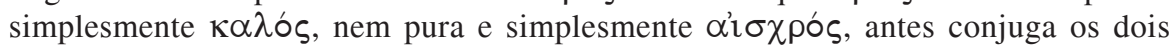
$\operatorname{aspectos}^{51}$. Em suma, a união entre Пópos e Пદví $\alpha$ designa como que a estrutura fundamental comum a estas diferentes instâncias de $\mu \varepsilon \tau \alpha \xi v$ v: se assim se pode dizer, a matriz ou a forma do $\mu \varepsilon \tau \alpha \xi u ́$ enquanto tal.

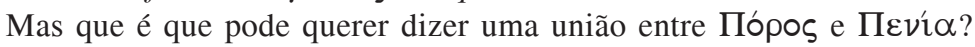

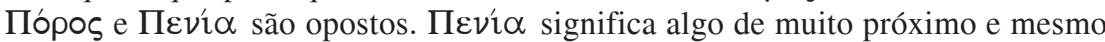

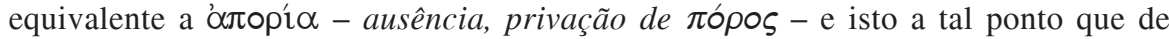
facto aparecem frequentemente associadas ${ }^{52}$. Пóp $\varsigma$ significa a passagem aberta que permite avançar, o acesso: o ter franqueado, o estar desimpedido, sem nada que prenda, impeça, vede - também a obtenção de uma passagem desta ordem, o ter meio de chegar a algo: o conseguir ${ }^{53}$. Пعvía significa a carência, a falta, a pobreza e, nesse sentido, justamente a situação de $\alpha$ đopí $\alpha$, i.e. de ausência de

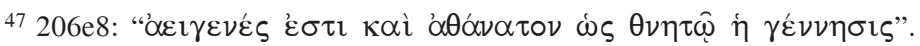

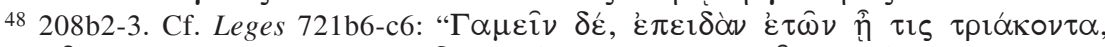

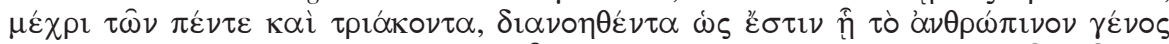

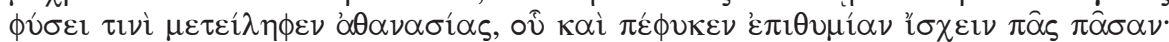

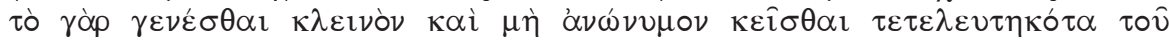

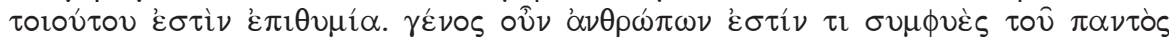

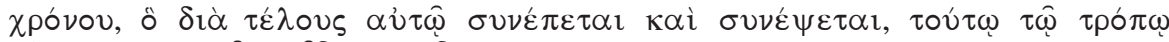

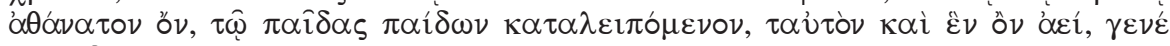

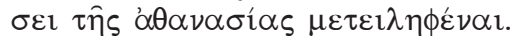

49 203d-e.

50204 b.

$51203 \mathrm{e}$.

52 Cf. Apêndice IV.

${ }^{53}$ Para um exame mais preciso do sentido de $\pi$ ópos, cf., por exemplo, G. STALLBAUM (ed.), Platonis opera omnia, vol. I, sec. III, Symposium, Gotha, Hennings, 1852, 129ss., W. 
RIBBECK (ed.), Die Ritter des Aristophanes, Berlin, Guttentag, 1867, ad 59, E. ZELLER, Die Philosophie der Griechen in ihrer geschichtlichen Entwicklung dargestellt, 2. Theil. 1. Abtheilung, Sokrates und die Sokratiker. Plato und die alte Akademie, Leipzig, Fues, $1875^{3}$, 513, G. F. RETTIG, Platons Symposion, Halle, Verlag der Buchhandlung des Waisenhauses, 1876, 270s., J. H. H. SCHMIDT, Synonymik der griechischen Sprache vol. I, Leipzig, Teubner, 1879, 477ss., A. W. VERRALL (ed.), The Choephori of Aeschylus, London, Macmillan \& Co, 1893, ad 70, R. C. JEBB (ed.), Sophocles The Plays and Fragments III The Antigone, Cambridge, University Press, 1891, ad 360, L. ROBIN, La théorie platonicienne de l'amour, Paris, Alcan, 1908, 12s., R. A. NEIL (ed.), The Knights of Aristophanes, Cambridge, University Press, 1909, ad 759, M. RUDOLPH, Poros, Diss. Marburg, 1912, U. von WILAMOWITZ-MOELLENDORFF, Platon. Sein Leben und seine Werke, ed. B. Snell, Berlin/Frankfurt a. M., Weidmann, 1948², 298ss. P. GROENEBOOM (ed.), Aeschylus' Prometheus, Groningen, Wolters', 1928, ad 57-59, G. CALOGERO, Il Simposio di Platone. Versione e saggio introduttivo, Bari, Laterza, 1928, 40, C. RITTER, Platonische Liebe, Tübingen, Buchdruckerei des Tübinger Studentenwerks, 1931, 35, U. von WILAMOWITZ-MOELLENDORFF, Der Glaube der Hellenen, Berlin, Weidmann, 1931-1932, reimpr. Darmstadt, Wissenschaftliche Buchgesellschaft, 1984, vol. I, 352, J. DUMORTIER, Les images dans la poésie d'Eschyle, Paris, Les Belles Lettres, 1935, 175s., U. GALLI (ed.), Platone Il Simposio, Torino, Chiantore, 1935, LXVIIss., ad 203b, O. BECKER, Das Bild des Weges und verwandte Vorstellungen im frühgriechischen Denken, Berlin, Weidmann, 1937, 23, 25, 28, 31, 120ss., 125, 148s., H. FRÄNKEL, Dichtung und Philosophie des frühen Griechentums, München, Beck, 1962, 1976², 183s., 290, G. KRÜGER, Einsicht und Leidenschaft. Das Wesen des platonischen Denkens, Frankfurt a. M., Klostermann, 1939, 19744, 52s., 155s., K. KERÉNYI, Hermes der Seelenführer, Zürich, Rhein-Verlag, 1944, 64ss., G. MARTANO, Interpretazione esistenzialistica di un mito antico, Giornale Italiano di Filologia 1 (1948), 257-259, D. L. PAGE (ed.), Alcman: the Partheneion, Oxford, Clarendon Press, 1951, 33ss., A. VANHOYE, Deux pages poétiques de Platon (Banquet 203b-203e), Les études classiques (1952), 3-11, A. M. DALE (ed.), Euripides Alcestis, Oxford, Clarendon Press, 1954, ad 213-14, F. NOVOTNÝ, Poros, otec Erotuv, Listy Filologicke 7 (1959), 39-49, H. J. CLASSEN, Sprachliche Deutung als Triebkraft platonischen und sokratischen Philosophierens, München, Beck, 1959, 130s., C. M. BOWRA, Greek Lyric Poetry. From Alcman to Simonides, Oxford, Clarendon Press, 1961, 19672, 26, 41, R. S. BLUCK (ed.), Plato's Meno, Cambridge, University Press, 1961, ad 78d3-4, M. PLATNAUER (ed.), Aristophanes Peace, Oxford, Clarendon Press, 1964, ad 124, J. ORTEGA Y GASSET, Historia como sistema, Madrid, Revista de Occidente, 1975², 131-132, IDEM, La idea de principio en Leibniz y la evolución de la teoría deductiva, Madrid, Revista de Occidente, 1967², 149ss., J. WIPPERN, Eros und Unsterblichkeit in der Diotima-Rede des Symposions, in: H. FLASSHAR/ K. GAISER (ed.), Synusia. Festgabe für W. Schadewaldt zum 15. März 1965, Pfullingen, Neske, 1965, 123-159, em especial 146, H. BUCHNER, Eros und Sein. Erörterungen zu Platons Symposion, Bonn, Bouvier, 1965, 83s., K. REINHARDT, Personifikation und Allegorie, in: IDEM, Vermächtnis der Antike. Gesammelte Essays zur Philosophie und Geschichtsschreibung, Göttingen, Vandenhoeck \& Ruprecht, 1966, 7-40, em especial 28, S. ROSEN, Plato's Symposium, N. Haven, Yale University Press, 1968, 232ss., G. MÜLLER, Antigone, Heidelberg, Winter, 1967, 84, J.-P. VERNANT, Thétis et le poème cosmogonique d'Alcman, in: Hommages à M. Delcourt, Bruxelles, Latomus, 1970, 38-69, D. BREMER, Licht und Dunkel in der frühgriechischen Dichtung. Interpretationen zur Vorgeschichte der Lichtmetaphysik, Bonn, Bouvier, 1976 (Archiv für Begriffsgeschichte Supplementheft 1), 246, 324ss., 333ss., M. DETIENNE/J.-P. VERNANT, Les ruses de l'intelligence. La mètis des Grecs, Paris, Flammarion, 1974, 25s., 29, 46, 105s.,110s., 136s., 142-151, 166, 211s., 215, 273s., 276, 298, K. DOVER (ed.), Plato Symposium, Cambridge, 
passagem, carência de meios, falta de alcance: o estar-retido-fora-de, impedido,

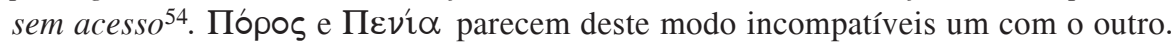
Em relação a o que quer que seja - é o que parece - ou se está numa situação de

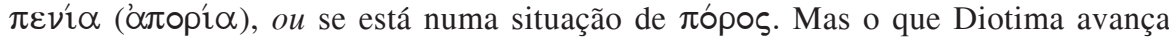

University Press, 1980, reimpr. 1993, 141s., F. HARTOG, Le miroir d'Hérodote. Essai sur la représentation de l'autre, Paris, Gallimard, 1980, nova ed. rev. aum., 2001, 121, 129s., 132s., 134, 313, 332, R. BRAGUE, Le restant. Supplément aux commentaires du Ménon de Platon, Paris, Les Belles Lettres/Vrin, 1978, 142, 148, S. KOFMAN, Beyond Aporia?, in: A. BENJAMIN (ed.), Post-structuralist Classics, London, Routledge, 1988, 7-44, S. GRAEFE, Der gespaltene Eros —Platons Trieb zur Wisheit, Frankfurt a. M., Lang, 1989, 130ss., 143ss., D. M. HALPERIN, Why is Diotima a Woman? , in: IDEM et al. (ed.), Before Sexuality. The Construction of Erotic Experience in the Ancient Greek World, Princeton, (NJ), Princeton University Press, 1990, 257-308, em especial 293s., B. MARZULLO, I sofismi di Prometeo. Firenze, La Nuova Italia, 1993, 224s., 226ss., 228, 501, 518, M. GRIFFITH (ed.), Aeschylus Prometheus Bound, Cambridge, Cambridge University Press, 1983, ad 59, 477, R. PADEL, In and Out of the Mind: Greek Images of the Tragic Self, Princeton (NJ), Princeton University Press, 1992, 25s., 41s., 58s., 83, 89, 138, R. L. MITCHELL, The Hymn to Eros. A Reading of Plato's Symposium, Lanham/N.Y./London, University Press of America, 1993, 123s., C. SEGAL, Euripides and the Poetics of Sorrow. Art, Gender, and Commemoration in Alcestis, Hippolytus and Hecuba, Durham/London, Duke University Press, 1993, 41, 49, R. L. MITCHELL, The Hymn to Eros. A Reading of Plato's Symposium, Lanham/NY, University Press of America, 1993, 124, U. CURI, Endiadi. Figure della duplicità, Milano, Feltrinelli, 1995, 55ss., 117,130, 132ss., 156s., H. NEUMANN, Diotima's Concept of Love, American Journal of Philology 86 (1995), 33-59, em especial 50ss., M.-C. GALPÉRINE, Lecture du Banquet de Platon, Lagrasse, Verdier, 1996, 18ss., G. REALE, Eros dèmone mediatore. Il gioco delle maschere nel Simposio di Platone, Milano, Rizzoli, 1997, 170ss., C. PIRAS, Vergessen ist das Ausgehen der Erkenntnis. Eros, Mythos und Gedächtnis in Platons Symposion, Frankfurt a. M., Lang, 1997, 160ss., R. B. MARTÍNEZ NIETO, Poros: una divinidad cosmogónica olvidada, in: F. R. ADRADOS/A. MARTÍNEZ DÍEZ (ed.), IX Congreso Español de Estudios Clásicos, Madrid, 27 al 30 de septiembre de 1995. 4, Literatura griega, Madrid, Ed. Clásicas, 1998, 229-233, K. SIER, Die Rede der Diotima. Untersuchungen zum platonischen Symposium, Stuttgart/Leipzig, Teubner, 1997, 52s., 75s., C. SEGAL, Tragedy and Civilization. An Interpretation of Sophocles, Norman, University of Oklahoma Press, 1998, 154, 441, S. DOUGLAS OLSON (ed.), Aristophanes Peace, Oxford, Oxford University Press, 1998, ad 124, E. MESSIMERI, Wege-Bilder im altgriechischen Denken und ihre logisch-philosophische Relevanz. Würzburg, Königshausen \& Neumann, 2001, 36ss., 41ss., 56ss., M. P. NICHOLS, Socrates' Contest with the Poets in Plato's Symposium, Political Theory 32 (2004), 186-206, F. C. C. SHEFFIELD, Plato's Symposium. The Ethics of Desire, Oxford, Oxford University Press, 2006, 42ss. Veja-se também a discussão no final do Apêndice IV.

${ }^{54}$ Isso mesmo se documenta nas próprias formulações a que Diotima recorre para

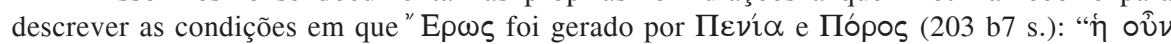

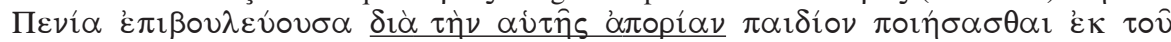

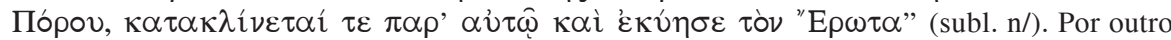

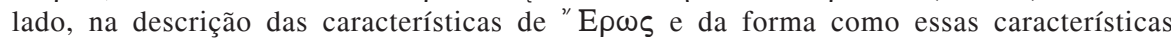
correspondem ao cruzamento de Пópos e Пદví $\alpha$, ao mesmo tempo que se insiste no uso de termos derivados de $\pi \delta$ ó

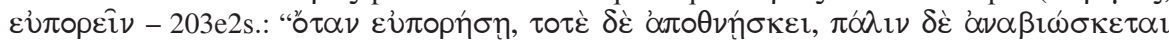


é que $\pi \varepsilon v^{\prime} \alpha$ e $\pi \delta ́ \rho \circ \varsigma$ não têm lugar somente nestas ocorrências separadas, em que são absolutamente estanques um ao outro e se excluem reciprocamente. Pois também há a possibilidade de qualquer coisa cuja natureza ou identidade própria corresponde à união dos dois e à fusão dos seus caracteres. Ou seja, há algo em que as duas instâncias opostas se conjugam - algo cuja identidade é justamente a desse cruzamento ou desse amálgama. Vendo bem, é para algo assim que aponta a ideia de um descendente comum de Пદví $\alpha$ e Пópos. Esse descendente herda, na sua constituição, os traços dos seus dois progenitores: tem ao mesmo tempo a natureza de $\pi \varepsilon v i ́ \alpha$ (a falta, a não-passagem, o não-acesso, o não-ter) e a natureza de $\pi \delta ́ p o \zeta$ (o desimpedimento, o alcance, a passagem, o acesso, o ter). E isto não em partes separadas - como se aquilo que o híbrido em causa tem de um e outro dos opostos em que radica se situasse em momentos completamente diferentes da sua composição (e como se em cada um desses momentos fosse plenamente $\pi \varepsilon \nu^{i} \alpha$ e plenamente $\pi$ $\delta$ pos). Não. O sentido para que as palavras de Diotima apontam é outro. O des-

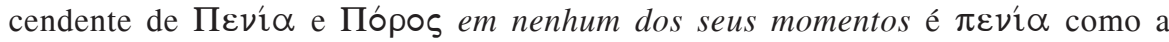
$\pi \varepsilon-\nu^{\prime} \alpha$ só $\pi \varepsilon \nu^{\prime} \alpha$ de que descende. Toda a $\pi \varepsilon \nu^{\prime} \alpha$ que nele se encontra é uma $\pi \varepsilon \nu i \alpha$ diminuída, contrariada, transformada pelo que também tem de $\pi$ ópos. E, inversamente, também em nenhum dos seus momentos o descendente de Пદví $\alpha$ e Пópos é $\pi$ ópos como o $\pi$ ópos só $\pi$ ópos de que descende. Todo o $\pi$ ópos que nele se encontra é um $\pi$ ópos diminuído, contrariado, transformado pelo que também tem de $\pi \varepsilon v i ́ \alpha$.

Esta ausência de qualquer momento de pura $\pi \varepsilon v i ́ \alpha$ ou de puro $\pi$ ópos, no híbrido de $\pi \varepsilon v^{\prime} \alpha$ e $\pi$ ópos que está em causa no discurso de Sócrates/Diotima, pode ser

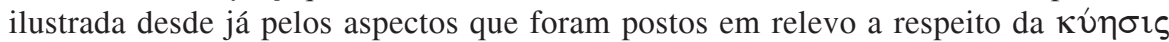

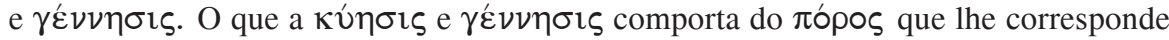
(a imortalidade) em nenhum momento é a imortalidade propriamente dita. Desta a

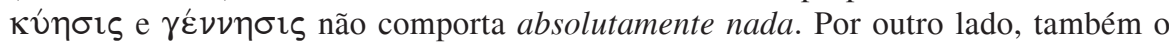

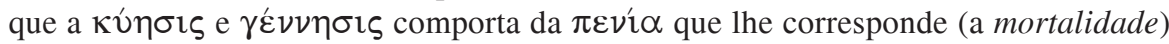
em nenhum momento é a mortalidade propriamente dita (o ser pura e simplesmente num instante, sem qualquer resistência ao desvanecimento, sem nada que o

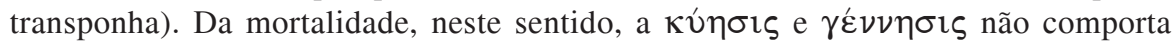
absolutamente nada. Tudo nela é sempre já transposição, transição, contra-mortalidade - ou seja, uma forma própria, original, de ser a imortalidade, não a sendo, ou de ser a mortalidade sempre já passando para lá dela.

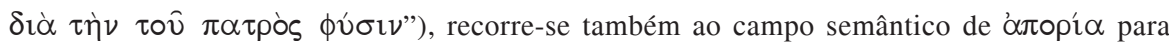

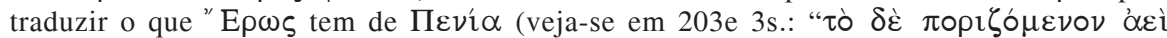

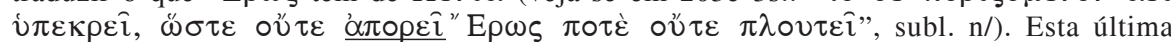
formulação reforça o sistema de correspondências e de oposições que tentámos pôr em foco, pois usa-se um derivado do mais óbvio antónimo de $\pi \varepsilon v i ́ \alpha$ ( $\pi \lambda \circ \hat{v} \tau \circ \varsigma$ ) para traduzir as características herdadas de Пópos. Claro até não mais na enunciação das relações de correspondência que aqui procuramos pôr em destaque é, finalmente, o passo de $204 \mathrm{~b} 5 \mathrm{~s}$ :

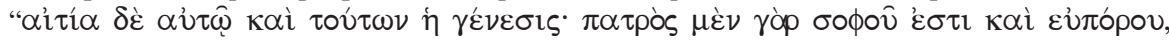

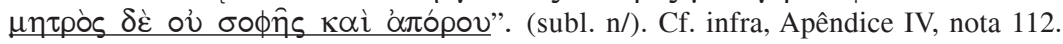


Em suma, o fruto da união entre Пópos e Пદví $\alpha$ possui a natureza de $\pi \varepsilon v i ́ \alpha$, mas no modo de $\pi \delta$ ós, transformada pela identidade de $\pi \delta$ ós que também é a sua. E possui a natureza de $\pi \delta \rho \circ \zeta$, mas no modo da $\pi \varepsilon \nu i \alpha$ : transformada pela identidade de $\pi \varepsilon v i ́ \alpha$ que também é a sua. Os dois aspectos não se anulam, nem se limitam a justapor-se: compenetram-se reciprocamente, de tal modo que cada

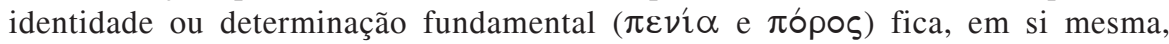
contaminada pela outra - se assim se pode dizer, alienada de si própria, mas de tal modo que não se dissipa, não se dissolve, não desaparece inteiramente a sua determinação. Ou seja, o híbrido de $\pi \varepsilon v i ́ \alpha$ e $\pi$ ópos é de algum modo consecução, obtenção, passagem, mas justamente de tal forma que, ao sê-lo, essa consecução, que já comporta, envolve ainda falta, não alcance, impedimento. E, por outro lado, é falta, impedimento, não alcance, mas de tal modo que, ao sê-lo, na falta, retenção, não alcance, que ainda comporta, já há consecução, passagem e alcance ${ }^{55}$.

${ }^{55}$ Para exprimir a peculiaridade do modelo formal em causa na noção de $\mu \varepsilon \tau \alpha \xi \hat{v}$, pode recorrer-se, por exemplo, a um passo de Troilus and Cressida de Shakespeare (IV, 5, 123 -134). Fala-se aí da dificuldade experimentada por Heitor, dada a impossibilidade de distinguir ou separar o que é grego e o que é troiano no seu adversário, Ajax, nascido de um cruzamento dos dois sangues: "Were thy commixtion Greek and Trojan so /That thou couldst say "This hand is Grecian all, /And this is Trojan; the sinews of this leg /All Greek, and this all Troy; my mother's blood /Runs on the dexter cheek, and this sinister /Bounds in my father's;' by Jove multipotent, /Thou shouldst not bear from me a Greekish member/Wherein my sword had not impressure made /Of our rank feud: but the just gods gainsay /That any drop thou borrow'dst from thy mother, /My sacred aunt, should by my mortal sword /Be drain'd!". Veja-se também o passo de Antonio's Revenge de John Marston (The Selected Plays of John Marston, ed. M. P. Jackson et al., Cambridge, Cambridge University Press, 1986), III, i, 164-169, para que remete H. N. HILLEBRAND (ed.), Troilus and Cressida (New Variorum Shakespeare), Philadelphia, Lippincott, 1953, ad loc. Neste passo, aparece também muito nítida e agudamente expresso o mesmo tipo de cruzamento onde já não é possível encontrar os elementos que foram cruzados: "O that I knew which joint, which side, which limb, / Were father all, and had no mother in't, /That I might rip it vein by vein and carve revenge / In bleeding races! But since 'tis mix'd together, / Have at adventure, pell mell, no reverse." Vendo bem, o modelo de crase implicado na noção de $\mu \varepsilon \tau \alpha \xi \dot{v}$ antecipa alguns aspectos fundamentais

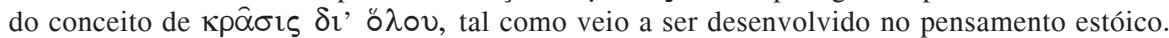
O conceito de $\kappa p \hat{\alpha} \sigma i \varsigma \delta \imath^{\prime}$ ǒ $\lambda \circ v$ designa uma forma de mistura ou combinação, cujos elementos estão tão completa e indissoluvelmente ligados ou fundidos uns com os outros que a mais pequena parte da $\kappa \rho \hat{\alpha} \sigma i \varsigma$ tem já um carácter misto, combinado, e contém de facto todos os

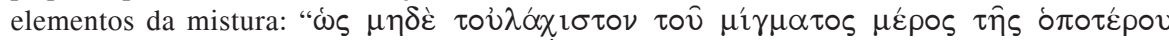

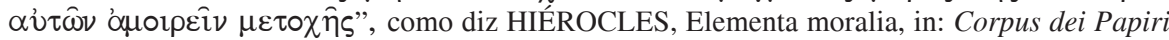
Filosofici Greci e Latini. Testi e lessico nei papiri di cultura greca e latina. Parte I: Autori noti, vol 1**, Firenze, Olschki, 1992, 268-451, col. IV, 7-8. Para determinar a peculiar natureza da relação entre corpo e alma e exprimir que se trata justamente de qualquer coisa como uma $\kappa p \hat{\alpha} \sigma i \varsigma \delta i$ ò $\lambda$ ov, Hiérocles compara a combinação entre o corpo e a alma àquilo que se passa com o ferro incandescente, no qual não há uma só componente, por mais pequena que seja, que não seja simultaneamente ferro e fogo (ibi, IV, 3ss.: " $\delta \varepsilon v ́ \tau \varepsilon \rho o \nu ~ \delta \dot{\varepsilon} \varepsilon \pi \grave{\imath} \tau \omega \hat{\omega} \delta \varepsilon$

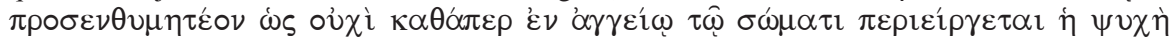

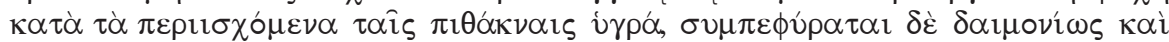


Tomando como base as formulações usadas por Diotima na caracterização do

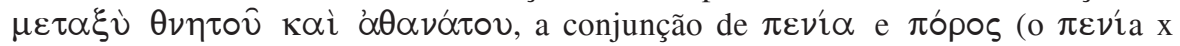
$\pi$ ópos) que procurámos apresentar como correspondendo à estrutura do $\mu \varepsilon \tau \alpha \xi \hat{v}$ pode,

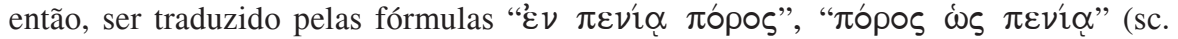

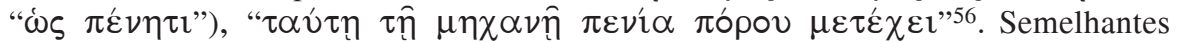
fórmulas não se acham no próprio texto do Symposium, mas também não correspondem

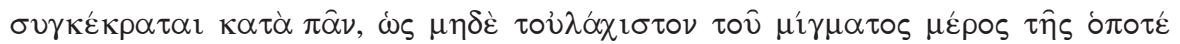

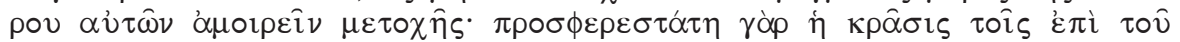

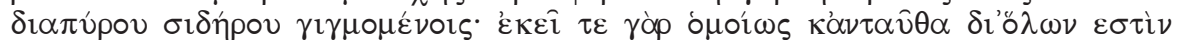
$\eta \pi \alpha \rho o ́ \theta \varepsilon \sigma ı \varsigma "$. Cf. ALEXANDRE de AFRODÍSIAS, De anima libri mantissa, apud I. BRUNS (ed.), Alexandri Aphrodisiensis praeter commentaria scripta minora (Commentaria in Aristotelem Graeca, 2.1), Berlin, Reimer, 1887, 115 (=SVF II 797), assim como a exposição das diferentes formas de $\mu \imath \hat{\imath} \xi \varsigma$ distinguidas na doutrina de Crísipo, apresentada por ALEXANDRE DE AFRODÍSIAS, De mixtione, apud I. Bruns (Hrsg.), Alexandri Aphrodisiensis praeter commentaria scripta minora (Commentaria in Aristotelem Graeca, 2.2), Berlin, Reimer,

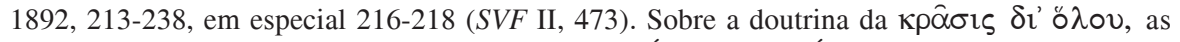
dificuldades que suscita, etc., veja-se em especial DIÓGENES LAÉRCIO, Vitae philosophorum, ed. M. Marcovich, Stuttgart/Leipzig, Teubner, 1999, VII, 150-151, bem como ALEXANDRE DE AFRODÍSIAS, De mixtione, op. cit., 221. Veja-se também M. POHLENZ, Die Stoa. Geschichte einer Bewegung, Göttingen, Vandenhoeck \& Ruprecht, 1959, vol. I, 72s., vol. II, 41s., R. B. TODD, Alexander of Aphrodisias on Stoic Physics. A Study of De mixtione with Preliminary Essays, Text, Translation and Commentary, Leiden, Brill, 1976, J. MANSFELD, Zeno and Aristotle on Mixture, Mnemosyne 36 (1983), 306-310, R. SHARVY, Aristotle on Mixtures, Journal of Philosophy 80 (1983), 441-8, B. INWOOD, Hierocles: Theory and Argument in the Second Century A. D., Oxford Studies in Ancient Philosophy 2 (1984), 151184, em especial 163s., F. H. SANDBACH, Aristotle and the Stoics, Cambridge, Cambridge Philological Society, 1985, 33s., M. J. WHITE, Can Unequal Quantities of Stuffs be Totally Blended?, History of Philosophy Quarterly 3 (1986), 379-89, A. A. LONG/D. N. SEDLEY (ed.), The Hellenistic Philosophers, Cambridge, Cambridge University Press, 1987, vol. 1, 290ss., vol. 2, 287ss., G. BADALAMENTI, Ierocle Stoico e il concetto di $\sigma v v \alpha i \sigma \theta \eta \sigma i \varsigma$, Annali del Dipartamento di filosofia (Università di Firenze) 3 (1987), 53-97, em especial 93ss., R. SORABJI, The Greek Origins of Chemical Combination: Can Two Bodies be in the Same Place?, Proceedings of the Boston Area Colloquium in Ancient Philosophy 4 (1988), 35-63, M. D. BOERI, El valor de Alejandro de Afrodisia como fuente de la Stoa antigua: (a propósito de pneûma, tónos y krâsis), Méthexis 4 (1991), 129-136, J. ANNAS, Hellenistic Philosophy of Mind, Berkeley, University of California Press, 1992, 47ss., A. A. LONG, Soul and Body in Stoicism, Phronesis 27 (1982), 34-57, em especial 38ss. (=IDEM, Stoic Studies, Cambridge, Cambridge University Press, 1996, 224-249, em especial 230ss.), C.-U. LEE, Oikeiosis. Stoische Ethik in naturphilosophischer Perspektive, Freiburg/ München, Alber, 2002, 71ss., B. COLETTE-DUCIC/S. DELCOMINETTE, La théorie stoïcienne du mélange total, Revue de philosophie ancienne 24 (2006), 5-60, J. LACROSSE, Trois remarques sur la réception de la

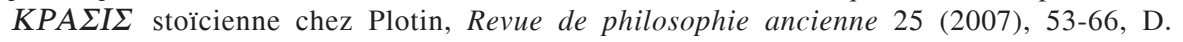
COHEN, Aperçu de la réception de la doctrine stoïcienne du mélange totale dans le néoplatonisme après Plotin, $i b i, 67-100$.

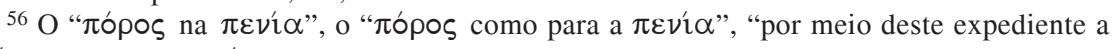

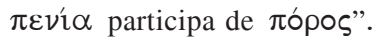


a extrapolações sem qualquer base nele - aquilo que se tentou pôr em evidência nas análises das palavras de Sócrates/Diotima aponta justamente para algo deste teor.

Mas aqui há um outro aspecto que importa ter em atenção para perceber minimamente aquilo para que Diotima aponta. A fusão de $\pi \delta$ ó mesma natureza não significa que os dois elementos estejam incluídos exactamente com o mesmo estatuto, a mesma função, sem nenhuma diferença - numa perfeita simetria. Não. A estrutura da fusão entre $\pi \delta ́ \rho \circ \zeta$ e $\pi \varepsilon v i ́ \alpha$ é a estrutura de algo orientado - e orientado no sentido que vai da $\pi \varepsilon v i ́ \alpha$ para $\pi \delta ́ \rho \circ \varsigma$. Quer dizer: o $\mu \varepsilon \tau \alpha \xi u ́$ está intrinsecamente marcado por tensão para o pólo positivo ou para o pólo de plenitude. $\mathrm{O} \mu \varepsilon \tau \alpha \xi v ́$ tem o carácter de qualquer coisa como o seu pólo positivo entravado pelo que tem de $\pi \varepsilon v i ́ \alpha$ - de tal modo que envolve, constitutivamente, a petição da ultrapassagem desse momento de $\pi \varepsilon v i ́ \alpha$ que embarga o $\pi \delta$ ós, a tendência para a superação do $\pi \delta$ ós-ainda-somente-no-modo-da- $\pi \varepsilon \nu i ́ \alpha$, por meio da obtenção de uma pura, plena posição de $\pi \delta$ ó $\varsigma^{57}$. Numa palavra, o $\mu \varepsilon \tau \alpha \xi \hat{v}$ tende, por natureza, para a superação de si próprio no seu pólo positivo, é indissociável dessa tendência para a ultrapassagem de si, não está "sossegado" em si, mas continuamente inquietado por uma atracção para fora de si, mais precisamente para se desfazer ou resolver naquilo que é da sua natureza ter por alvo: o simples $\pi$ ópo $\varsigma^{58}$.

${ }^{57}$ Essa peculiar forma de orientação (esse carácter "dirigido" ao "pólo positivo", dirigido ao $\pi$ ópos), que é própria das formas de realidade $\mu \varepsilon \tau \alpha \xi \hat{v}$, exprime-se muito claramente na

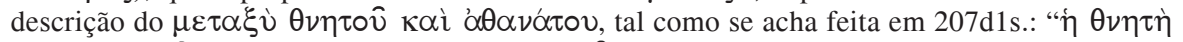

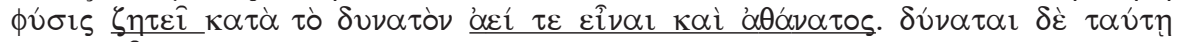

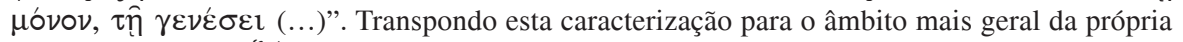
estrutura do $\mu \varepsilon \tau \alpha \xi v$, pode traduzir-se a orientação constitutiva das formas de realidade

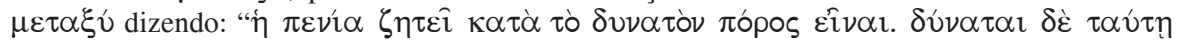
$\mu \delta$ vov, $\tau \hat{\omega} \mu \varepsilon \tau \alpha \xi \hat{v} "$. Também esta é uma fórmula que não se acha no próprio texto da intervenção de Diotima mas que corresponde àquilo que é possível encontrar analisando os fenómenos para que aponta. Aliás, vendo bem, é isso mesmo que Diotima enuncia com toda a

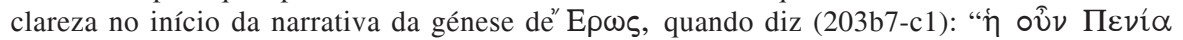

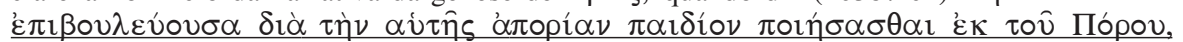

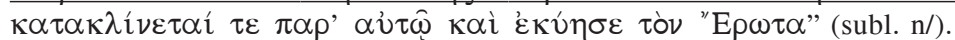

58 Aqui há sobretudo dois aspectos a assinalar. O primeiro diz respeito ao ő $\pi \varepsilon \rho$ है $\sigma \tau \iota \nu$ de que se falou acima. Os opostos (aquilo que corresponde respectivamente a $\pi \varepsilon v i \alpha$ e $\pi$ ópos) são plenamente isso mesmo que são, coincidem inteiramente consigo mesmos - sem qualquer distância, fissura, restrição. Mas o que caracteriza o $\mu \varepsilon \tau \alpha \xi u ́$ descrito por Diotima é, pelo contrário, o facto de aquilo que possui de cada um dos opostos que de certo modo o constituem o impedir de ser plenamente o outro deles. Nesse sentido, o $\mu \varepsilon \tau \alpha \xi u ́$ não é ǒ $\pi \varepsilon \rho ~ ع ้ \sigma \tau \iota v$, não é plenamente nada do que é - ou o seu ŏ $\pi \varepsilon \rho$ "̌ $\sigma \tau \iota v$ envolve justamente esta peculiar forma de não coincidência consigo, de expulsão de si - este não-estar-em-si-mesmo, não-ser- de-certo-modo-nada-do-que-é. Por outras palavras, o $\mu \varepsilon \tau \alpha \xi u ́ v$ desenhado por Diotima distingue-se por ser num a-meio-caminho que o põe à distância de si, em tensão entre os elementos que o compõem, ou melhor, entre aquilo que a sua constituição intrinsecamente sintética, amalgamada (mais: a sua composição em oposição ou conflito interno) põe-no em permanente confronto, em permanente desavença e, nesse sentido, em permanente desencontro consigo mesmo. Em suma, o $\mu \varepsilon \tau \alpha \xi u ́$ desenhado por Diotima distingue-se pela sua condição atravessada - em virtude da qual está sempre numa posição onde 
Tudo isto significa que, como Diotima aponta, o $\mu \varepsilon \tau \alpha \xi u ́$ é algo constitutivamente em trânsito, com o peculiar modo-de-ser que é o da passagem. Por um lado, o $\mu \varepsilon \tau \alpha \xi \hat{v}$ conecta, aproxima em si, através de si, aquilo que, sem ele, por sua própria natureza se mantém absolutamente afastado. Quer dizer: o $\mu \varepsilon \tau \alpha \xi \hat{v}$ atravessa a fronteira entre os opostos, estabelece uma comunicação entre planos que, de outro modo, não teriam contacto. Mas isso significa justamente que o $\mu \varepsilon \tau \alpha \xi u ́$ não está no intervalo entre os extremos do mesmo modo que cada extremo está na sua própria posição. O $\mu \varepsilon \tau \alpha \xi u ́ v$ é intermédio, situa-se entre, porque é intrinsecamente passagem, intrinsecamente no modo da passagem: intrinsecamente atravessado e atravessando entre os extremos, em trânsito de um para o outro - a ser esse trânsito. O $\mu \varepsilon \tau \alpha \xi \dot{v}$ descrito por Diotima dá-se e só se pode dar na forma de qualquer coisa como um a-caminho de $\pi \varepsilon v i ́ \alpha$ para $\pi o ́ \rho \circ \varsigma_{-}$ou seja, a transportar, a traduzir de uma determinação para a outra.

Ora, é precisamente isto que com muita nitidez se acha apontado por Diotima quando, no primeiro momento de identificação da instância intermédia entre o mortal e o imortal, descreve as funções dessa instância intermédia, o $\delta \alpha i ́ \mu \omega \nu$ e, em

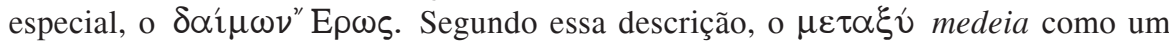
intermediário - trazendo e levando de um ao outro, fazendo a travessia entre um e o outro, transportando e traduzindo entre as duas margens. Ocupando esta posição intermédia e de passagem, o $\mu \varepsilon \tau \alpha \xi \hat{v}$ completa $(\underline{\sigma \nu \mu \pi \lambda \eta p o \hat{}})$ - e completa de tal modo que é por seu intermédio que o todo está em ligação (ou entra em ligação)

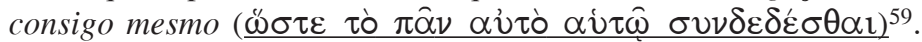

não pode ficar. $\mathrm{O}$ segundo aspecto que há a assinalar é o próprio carácter orientado desta tensão. Como vimos, não se trata pura e simplesmente de uma tensão entre essas determinações desencontradas, como se a tensão fosse simétrica ou fosse simétrico o papel que cabe a cada um dos termos envolvidos. Não. A tensão inerente ao $\mu \varepsilon \tau \alpha \xi u ́ v$ correspondente à fusão de $\pi \varepsilon v i ́ \alpha$ e $\pi$ ópos segue uma orientação muito definida. A forma própria e original de $\pi \varepsilon v i ́ \alpha$ x $\pi$ ópo sem o carácter de um $\pi$ ópos embargado (quer dizer, de uma $\pi \varepsilon v i ́ \alpha$ a tender para $\pi \delta$ ó contrário. E assim também nas diferentes modalidades de $\mu \varepsilon \tau \alpha \xi u ́$ descritas por Diotima e que são a expressão concreta desta fusão entre $\pi \varepsilon v i ́ \alpha$ e $\pi$ ópos. Pois o que está em causa na instância intermédia entre a mortalidade e a imortalidade é qualquer coisa como uma imortalidade embargada ou uma mortalidade a fugir a si própria - e não o contrário. Da mesma forma que o que está em causa na instância intermédia entre a ignorância e o saber é um saber embargado ou e uma ignorância a tentar fugir de si mesma, e não o contrário, etc.

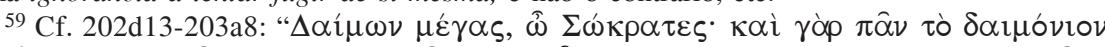

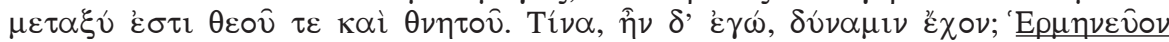

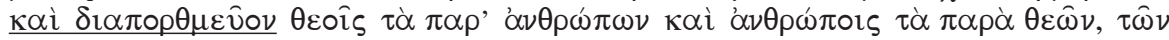

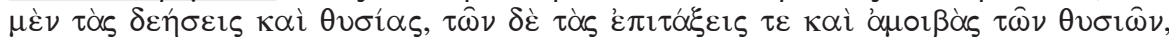

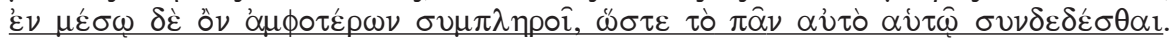

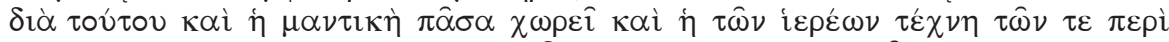

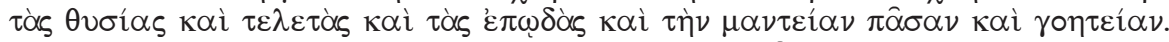

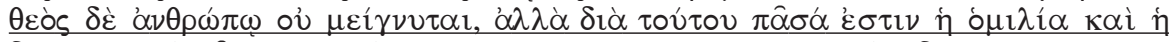

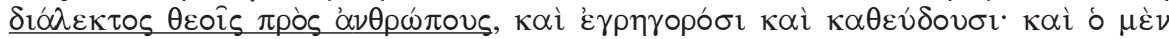

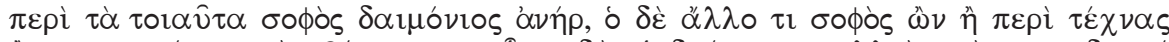

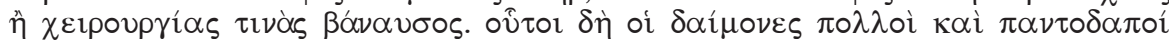

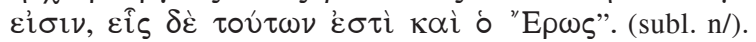


Desenham-se aqui com nitidez os fios de ligação que há entre as diferentes partes do discurso de Sócrates/Diotima, mesmo quando pertencem a registos diversos e aparentemente são desencontradas. Pois, como se percebe a partir do que acabamos de ver, nada do que é dito a respeito do $\delta \alpha \hat{\imath} \mu \omega \nu$ representa apenas um aspecto mais ou menos anedótico de caracterização mitológica de ع $\tilde{\rho} \omega \varsigma$ - um aspecto que fique para trás, abandonado, quando Diotima passa da primeira identificação do $\mu \varepsilon \tau \alpha \xi u ́ v$ (aquela em que o $\mu \varepsilon \tau \alpha \xi \dot{v}$ entre o mortal e o imortal é o $\delta \alpha \hat{\imath} \mu \omega \nu$ e ao $\mu \varepsilon \tau \alpha \xi \dot{v}$ entre a $\sigma o \phi^{\prime} \alpha$

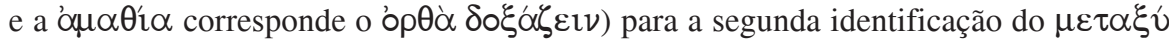

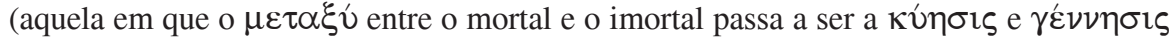
e o $\mu \varepsilon \tau \alpha \xi u ́$ entre o saber e a ignorância também passa a ser outra coisa: o $\phi 1 \lambda \circ \sigma \circ \phi \varepsilon i v$, ou seja, a procura e a forma de acesso que se tem quando se procura).

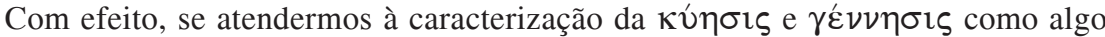
de intermédio entre o mortal e o imortal, verificamos logo que o tipo de realidade aí em causa se caracteriza por ser constitutivamente no modo da intermediação, da travessia, da passagem, algo em que sempre está excluída a quietude, uma forma de ser intrínseca e continuamente marcada por tensão, intrínseca e constitutivamente envolvida numa transmissão, num transporte entre opostos - no caso, a transmissão ou o transporte da diferença para a mesmidade, do desaparecimento para a subsistência, numa contínua (porque sempre precária e sempre ainda a ter de ser de novo feita) passagem da mortalidade à imortalidade (à imortalidade que só o é justamente por meio da passagem - da tensão, da transmissão). De sorte que aquilo

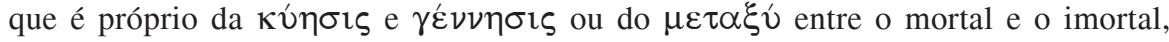
tal como Diotima o caracteriza, se presta a ser expresso exactamente nos termos da

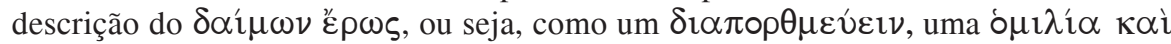
$\delta i \alpha ́ \lambda \varepsilon \kappa \tau O \varsigma$ entre a mortalidade e a imortalidade.

Há, entretanto, uma diferença fundamental que importa assinalar, pois perdê-la de vista significa perder de vista justamente aquilo que Diotima se esforça por

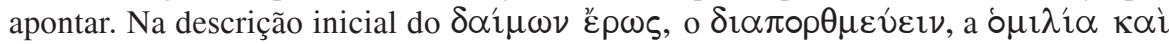

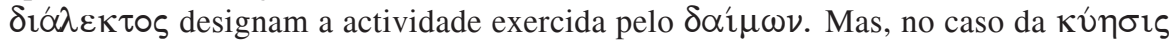
e $\gamma \varepsilon \dot{\varepsilon} \nu \nu \eta \iota \varsigma$ ou do $\mu \varepsilon \tau \alpha \xi u ́$ entre o mortal e o imortal, o $\delta 1 \alpha \pi \circ \rho \theta \mu \varepsilon v ́ \varepsilon \imath v$ não é pura e simplesmente uma actividade de algo (uma actividade que tem, por assim dizer, um carácter adjectivo em relação à realidade do ente que a exerce) mas sim a

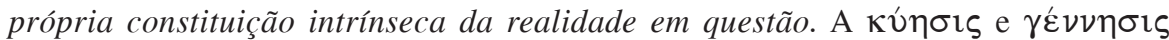
ou o $\mu \varepsilon \tau \alpha \xi v$ entre o mortal eo imortal é intrinsecamente essa constante ó $\mu \imath \lambda i \alpha$

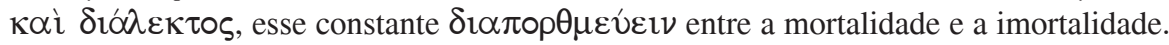
Não há em tal realidade absolutamente nada que não esteja já em si mesmo constituído neste peculiar modo-de-ser e não seja intrinsecamente isto: um $\delta 1 \alpha \pi \circ \rho \theta \mu \varepsilon v ́ \varepsilon \imath \nu$, uma

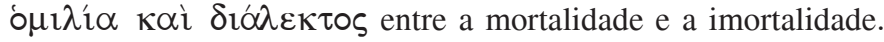

Não podemos alongar-nos sobre este ponto. Mas importa ter presente que é também algo desta natureza que está em causa quando Diotima fala do $\phi 1 \lambda \circ \sigma o \phi \varepsilon i v$ (quer dizer, dos fenómenos de procura, de encaminhamento e tensão para um saber que ainda não se tem, e da peculiar situação de acesso que os possibilita) como algo entre saber e não saber, ter e não-ter do que ainda não se sabe - instância intermédia ou $\mu \varepsilon \tau \alpha \xi \hat{v}$ na intersecção de ambos. 
A procura é impossível numa situação em que já se tem isso que se procura e é igualmente impossível numa situação em que isso esteja absolutamente não tido e se mantenha inteiramente fora do horizonte ${ }^{60}$. A procura só é possível numa terceira situação, correspondente ao $\mu \varepsilon \tau \alpha \xi \hat{v}$ das outras duas ${ }^{61}$ : quer dizer, não se trata apenas de algo que não é nem uma nem a outra, mas de algo que constitui como que um um-no-outro dos opostos em causa - algo em cuja natureza os caracteres dos dois ( $\pi \varepsilon v i ́ \alpha$ e $\pi$ ópos, ou seja, neste caso: ter e não-ter, saber e não-saber) se fundem, amalgamam, constituindo um e o mesmo acontecimento, com a natureza de uma contaminação recíproca de um pelo outro. E a estrutura específica deste ter já, que ao mesmo tempo ainda não tem, é retratada de forma que acentua a sua irredutibilidade a qualquer partição ou ocorrência separada de um ter/saber (puramente ter/saber), por um lado, e de um não-ter/não-saber (puramente não-ter/não-saber), por outro ${ }^{62}$. Aquilo para que o

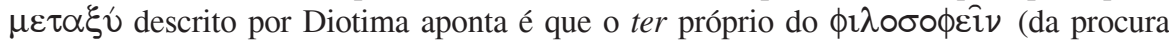
de saber) - o ter que põe em contacto com o procurado - é um ter que, apesar disso e no próprio acontecimento disso, não tem; e, inversamente, o não-ter, sem o qual não há lugar para a procura, é um não-ter que, apesar disso, e no próprio acontecimento disso, tem $^{63}$.

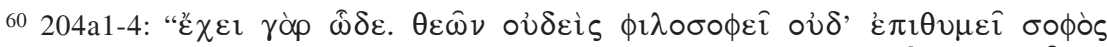

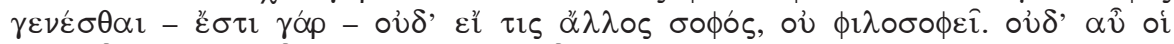

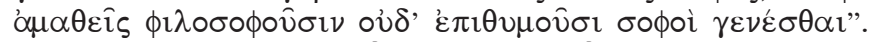

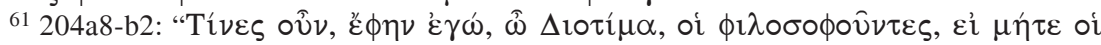

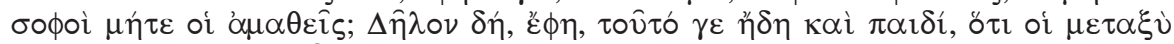

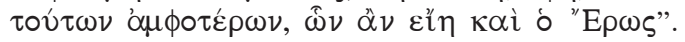

${ }^{62} \mathrm{Na}$ verdade, para haver procura, não basta que haja simultaneamente aspectos de ter $\mathrm{e}$ aspectos de não-ter, aspectos de saber e aspectos de não-saber. Pois, enquanto esses aspectos se mantiverem em ocorrências separadas e estanques, de tal modo que se sabe aquilo que se sabe (e a relação com aquilo que se sabe é apenas essa: a de o saber) e pura e simplesmente não se sabe aquilo que não se sabe (e a relação com aquilo que não se sabe é apenas essa: a de não o saber), não há quaisquer condições para procurar o que quer que seja. É importante vincar bem este ponto, porque há uma pronunciada tendência para iludir o problema aqui em causa, invocando a complexidade dos múltiplos respeitos em que se pode saber e não saber alguma coisa e julgando que, dessa forma, se consegue manter uma divisão partim/partim tal que se sabe (pura e simplesmente se sabe) uma parte disso e se ignora (pura e simplesmente se ignora) uma outra. Mas, como repetidamente se põe em evidência no corpus platonicum, se a relação que se tem é de saber (pura e simplesmente saber) aquelas "partes" que se sabem e não saber (pura e simplesmente não saber) as que não se sabem, isso produz justamente um grau zero de notificação de saber em falta e inviabiliza toda e qualquer procura. Com efeito, numa situação constituída desse modo, a única coisa que figura é o que se sabe - o que não se sabe pura e simplesmente não consta. Para que a procura possa ocorrer, é preciso um quantum mínimo de notícia do que falta - a qual notícia tem, por um lado, de ser já notícia disso mesmo (do que falta), pôr na sua pista, etc., mas, por outro lado, não pode anular com isso a recusa e o escondimento que justifica a procura e que esta se destina a ultrapassar ou suprimir. Numa palavra, a notícia do que falta tem de ter por força um carácter intermédio.

${ }^{63}$ É justamente para isso que aponta a aporia referida por Platão em passos como o Meno 80d5ss., 85dss., o Charmides 175c, o Euthydemus 275d-277c. A análise das condições de possibilidade da procura mostra que ela pura e simplesmente não é possível onde a relação entre saber e não saber (ter e não-ter, etc.) for uma relação de contraditoriedade, que não 


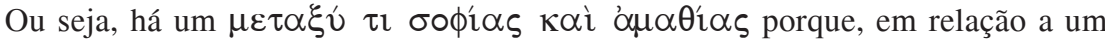
qualquer objecto de conhecimento ou a um qualquer cognoscível, as formas de relação possível não se esgotam no puro e simples não-saber (que em absoluto o ignora) e no puro e simples saber (que em absoluto já o alcança). Para além disso, há também a possibilidade de uma relação com um cognoscível constituída de tal forma que, ao mesmo tempo, já está de algum modo ida a ele (já dispõe de uma notícia a seu respeito, já se acha dirigida a ele, focada nele, em tensão para ele) mas, por outro lado, ainda não o encontra (ainda o deixa fora de alcance, inacessível: em recusa). Segundo Platão, é precisamente isso que se passa onde quer que tenha lugar a procura de um saber ainda em falta. Ora, esta condição intermédia na ordem

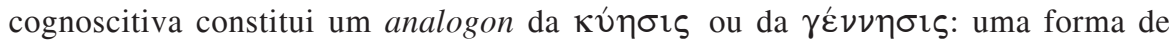
$\kappa v ́ \eta \sigma \iota \zeta$ e de $\gamma \dot{\varepsilon} \nu \nu \eta \sigma \iota \varsigma$ em relação ao conhecimento. Isto não porque também aqui seja precisa uma transposição que, de instante a instante, assegure a própria continuação da perspectiva em causa. Segundo Diotima, tal transposição é precisa, mas agora não é disso que se trata. Aquilo de que se trata agora é que, na procura

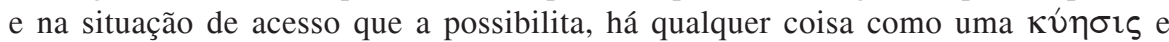
$\gamma \varepsilon \dot{\varepsilon} \nu \eta\rceil \iota \zeta$ em relação ao conhecimento num segundo sentido - a saber: porque a forma intermédia de acesso, que é própria da procura, é uma forma de acesso que gera em si o projecto de (e a tensão para) um outro acesso que não ela - mais precisamente, o projecto de (e a tensão para) o saber que procura, de que sente a falta. Nesse sentido, trata-se de uma forma de acesso que é portadora, em si mesma, de um outro acesso, diferente de si - a que ainda não chega na plenitude do que lhe corresponderá, mas de que já está, por assim dizer, grávida ${ }^{64}$. O $\mu \varepsilon \tau \alpha \xi \tilde{v}$ aqui em causa é, assim, qualquer coisa que transmite o não-tido ao ter, traz o não-tido à esfera do ter ou, inversamente, leva o ter ao não tido. Constitui algo que, parafraseando as fórmulas anteriormente citadas, se pode descrever assim: "Év $\alpha \mu \alpha \theta i \alpha$

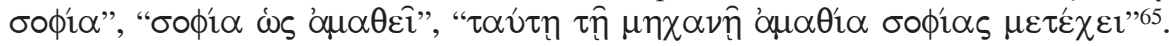

admite qualquer $\mu \varepsilon \tau \alpha \xi u ́$. Para que a procura seja possível, tem de haver um $\mu \varepsilon \tau \alpha \xi u ́$. E esse $\mu \varepsilon \tau \alpha \xi \dot{v}$ (que dá notícia daquilo que não se sabe) tem de corresponder a qualquer coisa como um saber-aquilo-que-não-se-sabe e não-saber-aquilo-que-se-sabe. Cf. Theaetetus 196d-e. Não pertence aqui produzir uma discussão deste complexo de problemas, cuja análise, porém, é decisiva para se perceber bem aquilo para que Diotima aponta, quando fala do $\mu \varepsilon \tau \alpha \xi v ́ v 1$

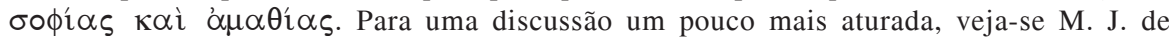
CARVALHO, Problemas fundamentais de fenomenologia da finitude, op. cit., vol. II, 1382ss. 1433ss., Vol. III, 290ss.

${ }^{64} \mathrm{Ou}$, para ser mais preciso, pode-se dizer que o acesso intermédio (o acesso da procura)

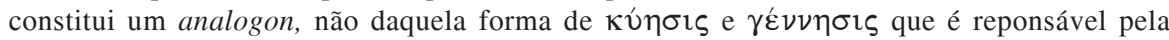
subsistência do próprio indivíduo, mas daquela que tem que ver com a geração de outros indivíduos, diferentes do próprio. Pois o acesso característico da procura não tende apenas para a renovação de si (para "mais de si") mas para um outro acesso superior a ele (que vá aonde ele mesmo ainda não chega).

${ }^{65} \mathrm{O}$ "saber na ignorância", o "saber como para quem ignora", "por via deste expediente a ignorância participa do saber". Estas fórmulas não se acham no próprio texto de Platão. Resultam de uma variação sobre ele - transcrevendo o que diz sobre a instância intermédia entre o mortal e o imortal para o caso da instância intermédia entre o saber e a ignorância. 
O que nos leva a um outro aspecto que já se deixa vislumbrar a partir daqui e que é o seguinte. Também no que diz respeito à instância intermédia entre o saber e o ignorar o $\mu \varepsilon \tau \alpha \xi \hat{v}$ de que Diotima fala não é nada de parado (algo que pura e simplesmente está, numa posição intermédia), mas antes qualquer coisa que constitutivamente tem lugar no modo da travessia: como passagem, trânsito, transferência entre as duas margens - a transpor de $\pi \varepsilon v i ́ \alpha$ para $\pi$ ópos, do não-saber para o saber, a transportar de um para o outro. Assim como na instância

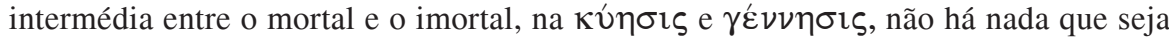
propriamente mortal ou propriamente imortal, antes sucede que tudo é intrinsecamente $\mu \varepsilon \tau \alpha \xi \hat{v}$ e transmissão (transporte, passagem), assim também na procura (sc. no acesso especificamente responsável pela procura) não há nada que ainda seja propriamente mera ignorância nem nada que já seja propriamente saber ou conhecimento. A procura está sempre já constituída por uma transposição para lá da mera ignorância, que, todavia, ainda não chega ao próprio conhecimento ou ao saber, antes se mantém numa posição intermédia - de passagem, de encaminhamento ou a-caminho: além da simples ignorância, aquém do saber ainda em falta.

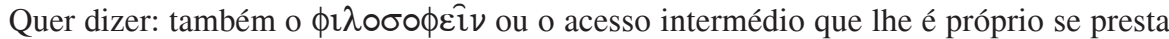
a ser expresso nos termos da descrição do $\delta \alpha \hat{\imath} \mu \omega \nu^{\prime \prime}$ E $\rho \omega \varsigma$. Pois corresponde a qualquer coisa como um $\delta \imath \alpha \pi \circ \rho \theta \mu \varepsilon v ́ \varepsilon \imath \nu$ ou uma ó $\mu \imath \lambda i ́ \alpha \kappa \alpha i ̀ ~ \delta i \alpha \lambda \varepsilon \kappa \tau o \zeta$ entre o não-saber e o saber. E isto de tal modo que também neste caso o $\delta 1 \alpha \pi \circ p \theta \mu \varepsilon v ́ \varepsilon \imath$,

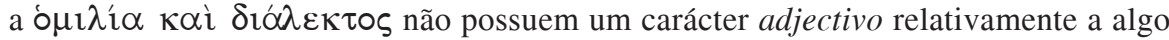
que em si mesmo não está constituído como $\delta 1 \alpha \pi \circ \rho \theta \mu \varepsilon v ́ \varepsilon \imath v$. Pois o que sucede é precisamente que o saber intermédio, o $\mu \varepsilon \tau \alpha \xi \hat{v}$ de saber e não-saber, é em si mesmo intrinsecamente um $\delta \imath \alpha \pi \circ \rho \theta \mu \varepsilon v \varepsilon \varepsilon \imath \nu$, uma $\delta \mu \imath \lambda i \alpha \kappa \alpha i \delta \delta \alpha \lambda \varepsilon \kappa \tau O \varsigma$ entre o não-saber e o saber. Tudo isto, finalmente, de tal modo que também aqui, em total consonância com a estrutura formal que assinalámos, o $\mu \varepsilon \tau \alpha \xi \hat{v}$ por natureza tende para a superação de si no seu pólo positivo, é indissociável dessa tendência para a ultrapassagem de si, não está "sossegado" em si, mas continuamente inquietado por uma atracção para fora de si - para o $\pi$ ópos inteiramente tal correspondente à $\pi \varepsilon v^{\prime} \alpha$ que o afecta (ou seja, no caso, para o saber que lhe falta) ${ }^{66}$.

Mas esta variação ou adaptação não corresponde senão à explicitação de algo em cuja direcção o texto claramente aponta. E exprime muito incisivamente a natureza da peculiar forma de acesso intermédio em cujo reconhecimento e em cuja caracterização Diotima insiste.

${ }^{66}$ Assinalemos finalmente dois pontos. O primeiro ainda se prende com a similitude

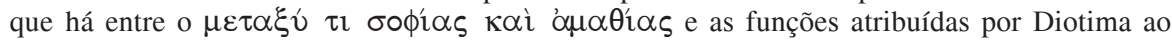

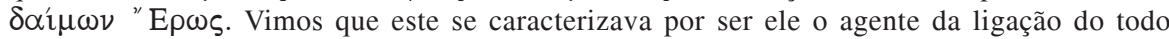
consigo mesmo - de sorte que, sem ele, haveria completa cisão ou completa separação daquilo

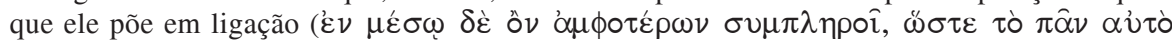
$\alpha \hat{v} \tau \hat{\omega} \sigma \nu \nu \delta \varepsilon \delta \varepsilon \delta \theta \alpha 1)$ e as duas margens entre as quais faz ponte estariam como que de costas inteiramente voltadas - completamente separadas e alheadas uma da outra. Vemos agora que é exactamente isto que é também operado pela instância intermédia entre o saber e o ignorar. Sem ela, os dois territórios (o daquilo que alguém sabe e o daquilo que ignora) estariam completamente separados um do outro, como que "de costas" um para o outro - totalmente fechados um para o outro. Até poderia haver como que "deslocações", em virtude das quais 
Em suma, basta olhar um pouco mais atentamente para os fenómenos que Diotima refere como instâncias intermédias ou casos de $\mu \varepsilon \tau \alpha \xi v$, no sentido que tem em vista, e logo se percebe que esses fenómenos têm em comum não apenas serem constituídos por uma singular miscigenação ou mestiçagem de opostos (e a circunstância de essa miscigenação ou mestiçagem ter um carácter orientado e ser constitutivamente habitada por tensão), mas, para além disso, ainda o facto de esses híbridos realizarem em si a obra de mediação que Diotima atribui ao $\delta \alpha i ́ f \omega v-\mathrm{e}$ isto de tal modo que quer a vida, enquanto híbrido de mortalidade e imortalidade,

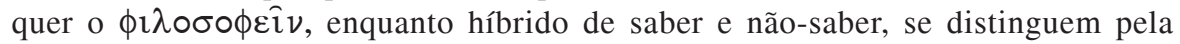
estranha propriedade de nunca se esgotarem em si próprios, de nunca ficarem onde estão, de não caberem em si e transbordarem, por assim dizer, em direcção a algo de outro, que é ao mesmo tempo o preenchimento, a completação ou plenitude daquilo que esses híbridos sempre já projectam e procuram ser.

\section{A condição intermédia e o humano. $O$ carácter multiplamente $\mu \varepsilon \tau \alpha \xi \tilde{v}$ do Humano. O Humano como $\varepsilon \rho \omega \varsigma, \mu \varepsilon \tau \alpha \xi \hat{v}$ e $\delta \alpha \hat{\imath} \mu \omega \nu$.}

Mas voltemos à questão do Belo e da nossa relação com ele - ou seja, à questão de saber afinal que é que o discurso de Sócrates/Diotima tem a dizer sobre essa relação.

Todos estes aspectos que vimos a respeito das instâncias intermédias entre o mortal e o imortal ou entre o saber e o não-saber interessam-nos aqui por aquilo que indiciam a respeito da relação com o Belo e do sentido em que o discurso de Sócrates/Diotima também fala de algo de intermédio entre o Belo e o seu oposto.

umas coisas deixassem de pertencer ao campo do não-sabido (e entrassem no campo do sabido) e outras seguissem o caminho inverso. Mas isso não alteraria a total ausência de pontos de contacto: o campo do sabido estaria completamente fechado nas suas próprias fronteiras e não teria nenhuma notícia de nada para lá delas. Ora, é a forma de acesso que possibilita a procura

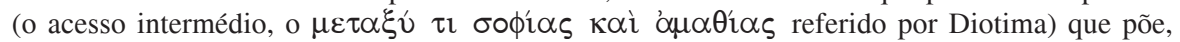
dentro do território do que se sabe, notícia do que não se sabe - quer dizer, do que fica para lá dele. E, desse modo, um campo de saber finito, limitado, vai ao mesmo tempo para lá das suas fronteiras e entra em ligação com esse para-lá e em tensão para ele $\mathrm{O}$ segundo ponto tem que ver com a estrutura da apresentação ou do acesso correspondente a este $\mu \varepsilon \tau \alpha \xi \hat{v}$ entre o saber e o ignorar. Também neste caso, ao contrário do que sucede com os extremos (o simples saber ou o simples ignorar - que são plenamente isso mesmo que são, coincidem inteiramente consigo mesmos), aquilo que o $\mu \varepsilon \tau \alpha \xi u ́$ tem de cada um dos opostos impede-o de ser plenamente o outro deles. Nesse sentido, a notícia de saber em falta não é ǒ $\pi \varepsilon \rho$ ع̌ $\sigma \tau \imath \nu$, não é plenamente nada do que é - ou o seu ǒ $\pi \varepsilon \rho$ ह̌ $\sigma \tau \imath \nu$ envolve justamente esta peculiar forma de não-coincidência consigo, de expulsão de si-este não-estar-em-si-mesma, não-ser-de-certo-modo-nada-do-que-é. Por outras palavras, a notícia de saber em falta está constitutivamente num a-meio-caminho que a põe à distância de si, em tensão entre os elementos que a compõem, em permanente desencontro e desavença consigo mesma. Em suma, esta forma de acesso distingue-se pela sua condição atravessada - em virtude da qual é mais do que ignorância e menos do que saber (ou é um não-saber que sabe e um saber que não sabe isso a que diz respeito) e está sempre numa posição em conflito consigo mesma - onde não pode ficar. 
Consideremos, então, o fundamental - e, antes do mais, o quadro global que resulta do que vimos e em que se vem inscrever essa modalidade específica de instância intermédia.

Antes do mais, como vimos, estas diferentes modalidades de $\mu \varepsilon \tau \alpha \xi u ́$ são apresentadas como momentos de ع $\rho \omega \varsigma$. Isto significa que, no discurso de Sócrates/Diotima, se produz qualquer coisa como uma transformação do significado da palavra है $p \omega \varsigma$ -

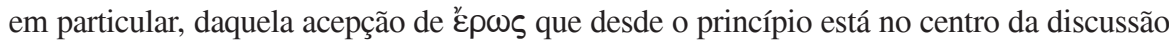

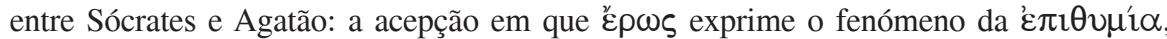
do desejo, etc. ${ }^{67}{ }^{\prime}$ E $\rho \omega \varsigma$ deixa de ser o nome para um fenómeno avulso, seja ele o poder do encanto ou o desejo enamorado (ou qualquer dos diversos fenómenos que espontaneamente são reconhecidos como desejo) e passa a designar um peculiar tipo de constituição de realidade: o modo-de-ser $\mu \varepsilon \tau \alpha \xi u ́$. Trata-se de uma forma de realidade constitutivamente atravessada entre opostos, constitutivamente feita de $\pi \varepsilon \nu^{\prime} \alpha$ votada à obtenção de $\pi$ ópos - ou seja, uma realidade de natureza intrinsecamente desiderativa, etc.

Vejamos bem as transformações de perspectiva que estão aqui em causa. São fundamentalmente duas.

A primeira tem que ver com o facto de este peculiar tipo de realidade,

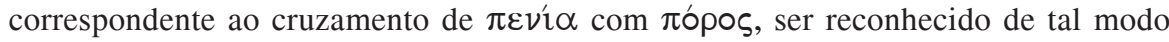
que se multiplicam as suas instâncias e ele aparece mesmo onde imediatamente não salta aos olhos a presença de algo que lhe corresponda ${ }^{68}$. Foi isso que vimos suceder, por exemplo, com os seres vivos que subsistem no tempo, etc. À primeira vista não parecem prestar-se a serem descritos como $\tilde{\varepsilon} \rho \omega \varsigma$ ou como algo $\mu \varepsilon \tau \alpha \xi \hat{v}$ no sentido aqui em causa, quer dizer, como algo constituído por conjugação de opostos correspondentes a $\pi \varepsilon \nu i ́ \alpha$ e $\pi$ ópos, pela sua fusão na mesma natureza - uma natureza que tem algo dos dois, mas por tal sorte que a) o que tem de um está transformado pelo que também tem do outro, i. e. alienado de si mesmo no seu oposto, e b) constitui qualquer coisa como uma privação ( $\pi \varepsilon v i \alpha)$ que de algum modo participa do $\pi$ ópos que lhe falta. Mas o desenvolvimento da intervenção de Sócrates/ Diotima leva a perceber que, de facto, os seres vivos que subsistem no tempo correspondem a realidades de tipo $\mu \varepsilon \tau \alpha \xi \hat{v}$, com uma natureza desiderativa, etc. E, por outro lado, também faz compreender que aquilo que torna essas realidades susceptíveis de serem reconhecidas como formas de ع̌ $\rho \omega \varsigma$ não diz respeito apenas a qualquer coisa que acontece com elas (como se o próprio núcleo dessas realidades em si mesmo nada tivesse que ver com $\tilde{\varepsilon} p \omega \varsigma$, fosse constituído de outro modo), antes concerne o próprio núcleo das realidades que subsistem no tempo - de sorte que não são apenas realidades que têm desejos, mas antes realidades intrinsecamente

${ }^{67}$ Já veremos se e como o discurso de Sócrates/Diotima também transforma o outro núcleo

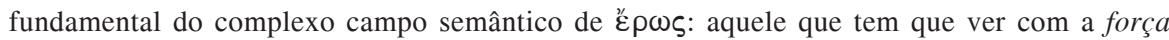
exterior que invade - i. e., aquele que tem que ver com o Belo na sua plenitude (ou, como também podemos dizer, usando a fórmula do Cratylus: aquele que tem que ver com o "ع̌ $\sigma \rho \varsigma^{\prime}$ "celebrado no discurso de Agatão).

${ }^{68}$ E espontaneamente nem "passa pela cabeça" que possa haver algo susceptível de vir a

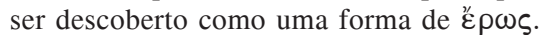


constituídas no modo do desejo - com natureza de desejos: realidades em si mesmas radical e constitutivamente desiderativas ${ }^{69}$.

${ }^{69}$ Vendo bem, estas modificações de perspectiva que se desenham no discurso de Diotima correspondem a uma tendência geral no desenvolvimento do Symposium de Platão, que elas vêm de certo modo coroar. Não cabe aqui analisar este ponto. Mas importa ter presente que, se considerarmos as modificações que ocorrem na sequência dos discursos de Fedro, Pausânias, Erixímaco, Aristófanes e Agatão, há, por assim dizer, dois eixos de transformação de perspectiva muito nitidamente desenhados. O primeiro diz respeito a qualquer coisa como um alargamento de âmbito ou a um alargamento da amplitude daquilo que é reconhecido como ě $\rho \omega \varsigma$. Assim,

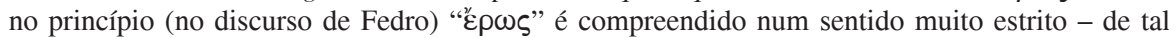
modo que corresponde apenas ao quadro específico da $\pi \alpha 1 \delta \varepsilon \rho \alpha \sigma \tau i$ í antiga, da relação entre o

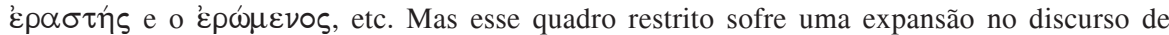

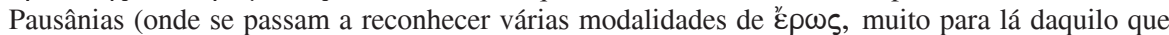
Fedro considerava). E esse alargamento experimenta um salto exponencial com a passagem para

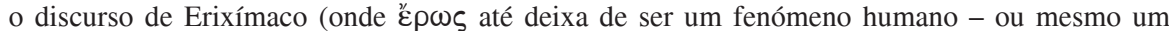
fenómeno próprio dos seres vivos - e se converte, por assim dizer, em algo verdadeiramente

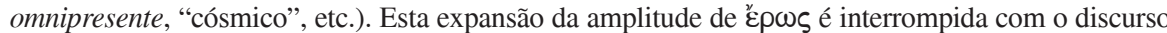
de Aristófanes, que representa uma considerável contracção de âmbito em relação ao discurso de

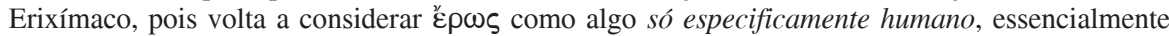
relacionado com as "relações amorosas", etc. Mas, sendo assim, por outro lado o discurso de Aristófanes dá seguimento a uma segunda linha de transformação que já anteriormente começava

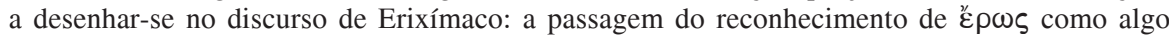
superveniente aos entes em que tem lugar e que ocorre de forma mais ou menos avulsa (por

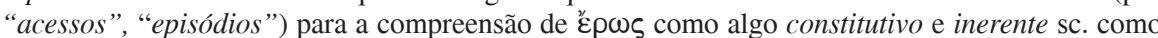
algo de permanente, que faz parte da própria natureza dos entes em que tem lugar. Como se disse, esta perspectiva assoma já nitidamente no discurso de Erixímaco. E, se o discurso de Aristófanes volta a circunscrever है $\rho \omega \varsigma$ na esfera humana, por outro lado, uma das mais importantes "novidades" que introduz é precisamente o facto de apresentar "̌p ser humano, é constitutivo, permanente (atravessando e moldando o nosso acontecimento em todos e cada um dos seus momentos) - de tal modo que, do princípio ao fim, a nossa vida é

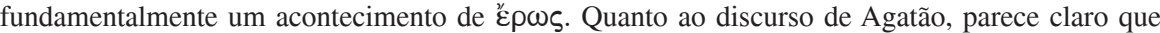
representa uma nítida contracção relativamente a estas duas linhas de desenvolvimento. Pois, por um lado, Agatão volta a descrever "̌p ao entendimento mais comum do fenómeno da paixão - e a sua concepção de ع̌p $\omega \varsigma$ está de facto muito mais próxima da de Fedro do que da de Pausânias (já para não falar de Erixímaco). E, por outro lado, o discurso de Agatão volta também à compreensão de ع̌p poder superveniente, que assalta de quando em quando, por "acessos" avulsos, etc. Ora, sendo assim, a intervenção de Sócrates/Diotima vem retomar as duas linhas de desenvolvimento que referimos, combinando-as de um modo novo em relação àquilo que se desenhava antes do discurso de Agatão - e, em especial, no discurso de Aristófanes. Pois as palavras de Sócrates/Diotima também

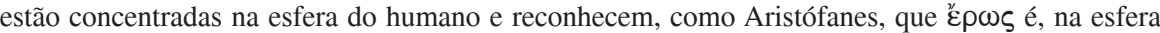
humana, algo constitutivo, permanente e total; mas, por outro lado, diferenciam isso que reconhecem como " $\varepsilon \omega \varsigma$ permanente, constitutivo e total, que define a natureza humana - de tal

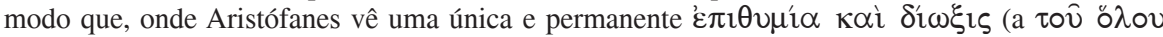

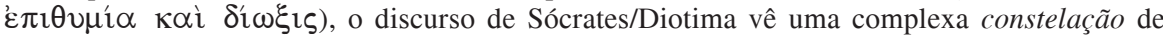

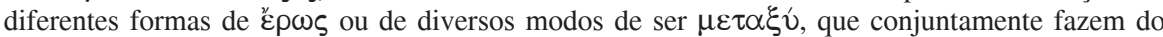

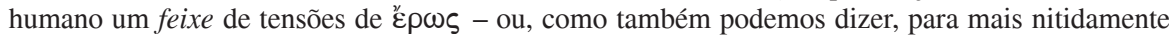
expressarmos aquilo de que se trata: algo integralmente constituído por um feixe de realidades intrinsecamente desiderativas em cruzamento umas com as outras. 
Assim, o discurso de Sócrates/Diotima produz qualquer coisa como uma expansão do território de ع́ $\rho \omega \varsigma$. A perspectiva aberta no discurso faz ver que aquilo que habitualmente já está reconhecido como $\varepsilon^{2} \rho \omega \varsigma$ (como $\varepsilon \pi \imath \theta u \mu i ́ \alpha$, como desejo) são apenas momentos de um complexo muito mais vasto que costuma passar completamente despercebido - e que costuma passar despercebido também porque, mesmo, em relação àquilo que habitualmente já chama a atenção como $\varepsilon^{\prime} \pi \imath \theta v \mu \mathfrak{i} \alpha$ ou $\varepsilon^{\prime} \rho \omega \varsigma$, não costumamos perceber bem o seu peculiar modo-de-ser (ou seja, o modo-de-ser cuja descoberta o discurso põe no seu centro: o modo-de-ser da instância intermédia, do

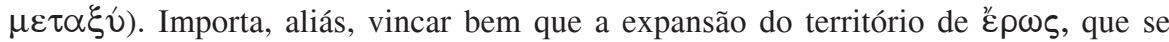
encontra desenhada no discurso de Sócrates/Diotima, vai tanto no sentido de uma multiplicação daquilo que é reconhecido como ép $\rho \varsigma$ (ou seja, como tendo uma natureza $\mu \varepsilon \tau \alpha \xi u ́)$, quanto também num outro sentido, que tende a passar despercebido mas que na verdade é tão importante como o primeiro: aquele que corresponde ao facto

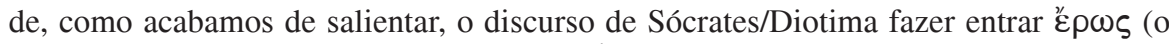
modo-de-ser que lhe corresponde: o $\mu \varepsilon \tau \alpha \xi u ́)$ no próprio núcleo das realidades em

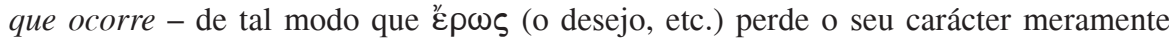
adjectivo (de algo que acontece com realidades em si mesmas constituídas de outro modo) e passa a constituir integralmente o campo das realidades em que tem lugar.

Por outras palavras, segundo Sócrates/Diotima há um duplo defeito na forma como comummente temos reconhecido o universo dos fenómenos desiderativos: há, por um lado, um defeito de amplitude (de sorte que uma significativa parte dos fenómenos de desejo é deixada de fora); e, por outro lado, associado a este, há também um defeito na própria forma como se compreende a estrutura constitutiva ou o modo-de-ser do desejo enquanto tal - defeito este que não deixa ver nem a estranha natureza do desejo (enquanto implica qualquer coisa como uma realidade ao mesmo tempo feita de excesso sobre si mesma e de defeito relativamente a esse excesso), nem a forma como as realidades $\mu \varepsilon \tau \alpha \xi \hat{v}$ são inteiramente $\mu \varepsilon \tau \alpha \xi \dot{v}$ (ou, como também podemos dizer, substantivamente - não apenas adjectivamente - desiderativas). Da supressão destes dois defeitos resulta qualquer coisa como uma extraordinária multiplicação das instâncias desiderativas ou a descoberta de que as realidades deste tipo são em muito maior número (e desenham um "universo" muito mais vasto) do que à primeira vista tende a parecer - de tal modo que o $\mu \varepsilon \tau \alpha \xi u ́$ aparece em todo o lado à nossa volta e constitui não apenas algo muito disseminado, mas, na verdade, qualquer coisa como um território compacto, maciço.

É para esta transformação de perspectiva que Diotima chama a atenção quando

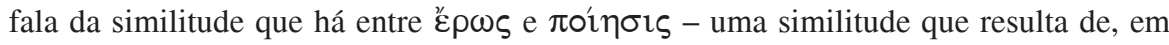
ambos os casos, reinar habitualmente como que a hipertrofia de uma acepção específica

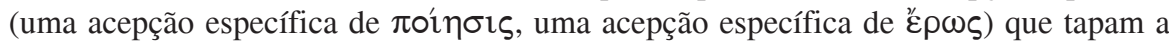
vista para todas as outras espécies de $\pi 0$ in $\sigma \iota \varsigma$ ou de $̌$ ع $\omega \varsigma$ e para a afinidade que há entre todas elas - quer dizer, para o radical comum $\pi$ oínoıৎ ou para o radical comum ع̌ $\rho \omega \varsigma$ e para todo o vasto território que de facto lhes corresponde ${ }^{70}$.

${ }^{70}$ Cf. 205. O contexto em que é vincada esta afinidade tem que ver com um aspecto específico - sobre o qual já nos vamos debruçar. Mas o que aí se diz tem, de facto, um alcance muito mais vasto, que aqui tentamos pôr em relevo. Pois, em boa verdade, aplica-se a todo o campo do $\mu \varepsilon \tau \alpha \xi v$. 
Mas isto ainda não é tudo. Há ainda uma segunda transformação de perspectiva introduzida pelo discurso de Sócrates/Diotima, na verdade tão decisiva quanto a primeira. Pois, como vimos, o que se encontra nas palavras de Diotima não é apenas a identificação de um tipo ou género de realidade, que se repete numa multiplicidade ou num arquipélago mais ou menos denso de instâncias avulsas, mas sim a clara sugestão da confluência ou acumulação de instâncias deste tipo (quer dizer, de diversos momentos de realidade $\mu \varepsilon \tau \alpha \xi \hat{v}$ ou de diversos momentos de algo com uma constituição intrinsecamente desiderativa, no sentido aqui em causa) na mesma realidade, que assim possui o carácter de algo multiplamente $\mu \varepsilon \tau \alpha \xi u ́$. Por outras palavras, há um ente que se distingue ao mesmo tempo por a) estar de raiz constituído, enquanto ser vivo, como $\mu \varepsilon \tau \alpha \xi v$ entre o mortal e o imortal, b) comportar uma tal relação com o saber que a sua posição corresponde a algo de intermédio entre o saber e o ignorar e c) ter ainda uma tal relação com o Belo que também se pode dizer a seu respeito que é $\mu \varepsilon \tau \alpha \xi u ́$ entre ele e o seu oposto. Ora, vendo bem, tal como Diotima o descreve, esse ente é o Ser Humano. Ou seja, Diotima encaminha tudo no sentido de mostrar que o Humano é multiplamente constituído por "componentes" $\mu \varepsilon \tau \alpha \xi u ́$. De tal modo que, pelo menos até certo ponto (não cabe aqui averiguar se chega a ser exclusivamente assim), o $\mu \varepsilon \tau \alpha \xi \dot{v}$ - e, nesse sentido,

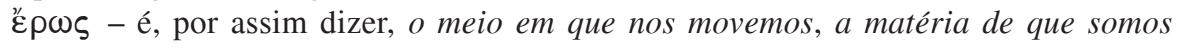
feitos: a nossa natureza e o nosso horizonte.

Este é um ponto decisivo em que não é demais insistir. Segundo Sócrates/Diotima, estamos constituídos de tal modo que nos distinguimos justamente por haver em nós qualquer coisa como uma acumulação de diferentes modalidades de realidade intrinsecamente desiderativa ou de diferentes modalidades de $\mu \varepsilon \tau \alpha \xi \hat{v}$. De tal modo que o defeito que habitualmente não nos deixa ver bem a totalidade daquilo que, de facto, tem uma natureza desiderativa (e ao mesmo tempo nos impede de nos capacitarmos da peculiar natureza do $\mu \varepsilon \tau \alpha \xi u ́$ enquanto tal) é um defeito que nos impede justamente de perceber aquilo que, pelo menos em grande parte, nos constitui a nós.

Isso não significa, forçosamente, que nós sejamos o único ente formado por realidades $\mu \varepsilon \tau \alpha \xi u ́$. E, como se disse, o discurso de Sócrates/Diotima também não chega a afirmar taxativamente que somos formados só por realidades dessa ordem - mesmo que, vendo bem, seja justamente nessa direcção que no fundo aponta. Mas, seja como for, Sócrates/Diotima procura mostrar que um ser humano forma um tal cruzamento e um tal concentrado de diferentes constituintes desse tipo (um tal cruzamento ou um tal concentrado de diversas modalidades de $\mu \varepsilon \tau \alpha \xi v$ ou de diferentes formas de realidade intrinsecamente desiderativa, no sentido referido) que

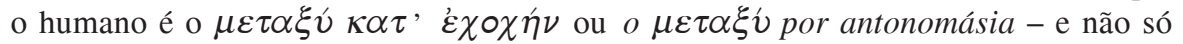
a mais própria determinação do humano é o $\mu \varepsilon \tau \alpha \xi \hat{v}$ mas um ser humano não se presta a ser compreendido senão a partir desta determinação fundamental e qualquer tentativa de compreensão do humano que não leve em conta tal determinação falha, de raiz, o próprio elemento em que o humano se move.

É isto que se exprime com muita nitidez na forma como o discurso de Sócrates/

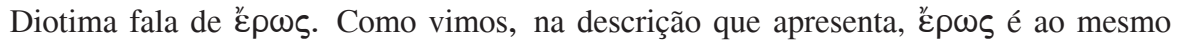
tempo: 
a) um tipo de realidade - a realidade intermédia (o modo-de-ser $\mu \varepsilon \tau \alpha \xi v$, que

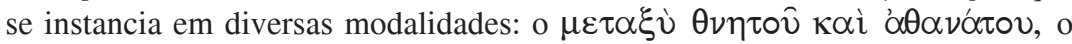

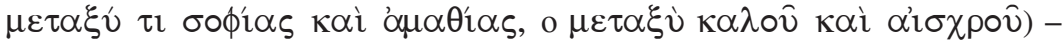
$\mathrm{e}$

b) um ente ou uma realidade em que confluem estas várias modalidades: um ente ou uma realidade ao mesmo tempo feito delas todas - quer dizer, um

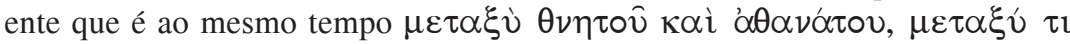

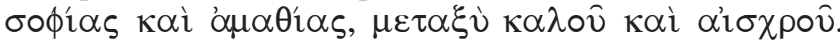

É verdade que Diotima insiste nesta unidade ou nesta confluência do $\mu \varepsilon \tau \alpha \xi u ́ v$ numa única entidade (que reúne ou acumula em si todas as diferentes modalidades de $\mu \varepsilon \tau \alpha \xi \hat{v})$ mas também é verdade que nunca chega a afirmar expressamente que essa entidade somos nós - é o ser humano. Porém, basta considerar um pouco mais atentamente que modalidades de $\mu \varepsilon \tau \alpha \xi u ́$ Diotima menciona, quais são os fenómenos em causa - e qual é o ente em que essas modalidades de $\mu \varepsilon \tau \alpha \xi u ́$ sc. os fenómenos que lhes correspondem estão reunidos - para perceber com nitidez que se trata do ser humano. Pois o que está em causa é algo que não apenas se caracteriza pela

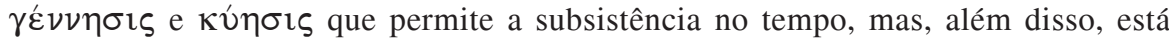
também marcado pela peculiar forma de acesso que é o acesso intermédio (aquele que permite a procura ou o $\phi \lambda \lambda \sigma \circ \phi \varepsilon i ̂ v)$ e, em terceiro lugar, tem também uma relação com o belo, mais propriamente uma relação tal que tende para ele a partir de qualquer coisa como uma constituição cruzada (correspondente à fusão, no modo de $\pi \delta$ ós x $\pi \varepsilon v^{\prime} \alpha$, entre ele e o seu oposto). Não importa discutir aqui se há ou não há outros entes, para lá de nós, que também corresponderão a esta descrição. $\mathrm{O}$ que importa é que, de todo o modo, nós lhe correspondemos - e que, de facto, ela nos assenta como uma luva e se presta a servir como descrição do nosso modo-de-ser.

Não podemos discutir aqui todos os problemas que isto levanta. Mas importa registar pelo menos três. Em primeiro lugar, põe-se a questão de saber se o elenco de modalidades de $\mu \varepsilon \tau \alpha \xi u ́$ apresentado por Diotima pretende ter um carácter exaustivo ou, pelo contrário, se destina apenas a dar uma primeira indicação, ainda provisória - cuja completação é deixada (como tantas vezes no corpus platonicum) à iniciativa do leitor. Por outras palavras, a expansão do território de ع้ $\rho \omega \varsigma$ (a supressão do defeito no reconhecimento das realidades de natureza intrinsecamente desiderativa e no reconhecimento da medida em que nós mesmos estamos constituídos desta forma) fica esgotada com o que Diotima diz - ou poderia e deveria prosseguir para lá do que ela mesma apresenta? Há (e somos nós) apenas $\mu \varepsilon \tau \alpha \xi \hat{v}$

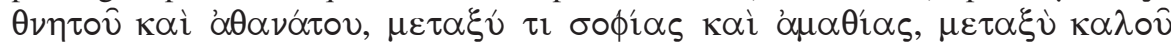
$\kappa \alpha i ̀ ~ \alpha ’ \sigma \chi p o \hat{~ o u ~ h a ́ ~(e ~ s o m o s ~ n o ́ s) ~ a i n d a ~ o u t r a s ~ m o d a l i d a d e s ~ d e ~} \mu \varepsilon \tau \alpha \xi \hat{v}$ para além dessas? Este é um problema que aqui deixamos em aberto. ${ }^{71}$

${ }^{71}$ Uma das expressões deste problema diz respeito às relações entre o $\kappa \alpha \lambda \sigma^{\nu}$ e o $\alpha \gamma \alpha \theta \dot{v} v$

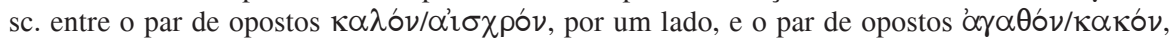
por outro - e à questão de saber se se pode e deve falar também de algo de intermédio entre

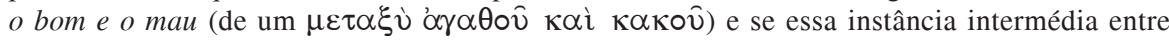


O segundo problema que importa considerar, ainda que só muito brevemente,

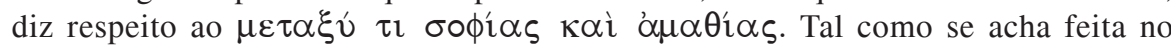
discurso de Sócrates/Diotima, a identificação desta instância intermédia como algo que corresponde à procura (e à situação de acesso que a possibilita) parece revestir-se de um alcance muito circunscrito. Pois a procura costuma ter um carácter meramente episódico e, por isso, os focos de acesso apenas intermédio que a

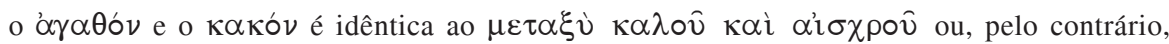
irredutivel a ele. O discurso de Sócrates/Diotima nunca chega a esclarecer este problema. Como vimos, a parte preliminar de diálogo entre Sócrates e Agatão refere ao mesmo tempo os dois pares de opostos, apontando ambos como casos em que a relação de oposição não exclui o cabimento de uma instância $\mu \varepsilon \tau \alpha \xi \hat{v}$. A ligação entre isso e os aspectos que entretanto se

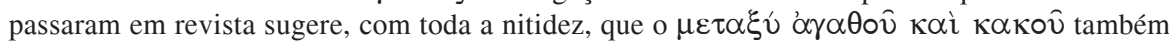
fará parte da constelação de instâncias $\mu \varepsilon \tau \alpha \xi u ́$ que o discurso de Sócrates/Diotima descreve como constituinte da condição humana. Mas, por outro lado, como também se viu, logo na parte introdutória de diálogo entre Sócrates e Agatão chama-se a atenção para um vínculo de associação e correspondência em virtude do qual se esbate ou apaga a diferença entre o

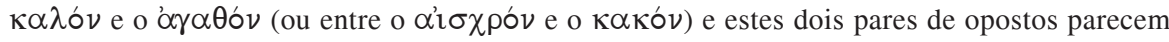
poder ser tratados como equivalentes. O que, por sua vez, parece implicar que o

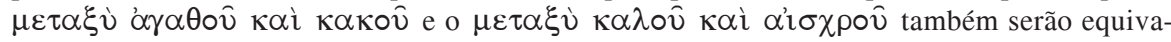
lentes e correspondem, em última análise, a um e o mesmo fenómeno. Este é, em suma, o panorama do que expressamente se apresenta na primeira parte do discurso de Sócrates/ Diotima. Acontece, porém, que este panorama deixa por responder algumas questões fundamentais - e designadamente: 1) Pode encarar-se esse assentamento feito de passagem, no diálogo preliminar com Agatão, como uma decisão definitiva, que arruma de vez o problema? Ou trata-se, pelo contrário, de um daqueles assentamentos tão frequentes no corpus platonicum, que sãofrágeis e que ou acabam por ser postos em causa algures, no próprio corpus, ou, de todo o modo, são deixados à iniciativa crítica de verificação por parte de quem lê? 2) Mas,

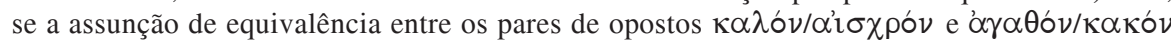
e as respectivas instâncias intermédias carece de solidez, significa essa fragilidade que se trata pura e simplesmente de um equívoco, sem outra consistência que não essa? Ou tal equivalência tem, em todo o caso, alguma base fenoménica, no sentido em que, na constituição dos seres

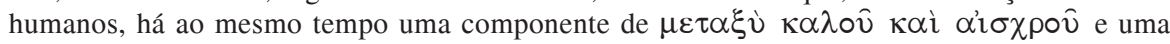
componente de $\mu \varepsilon \tau \alpha \xi \hat{v}$ ' $\gamma \alpha \theta \circ \hat{v} \kappa \alpha i ̀ ~ \kappa \alpha \kappa o v ̂$, não idênticas, mas que, no entanto, de raiz se prestam a serem confundidas e tendem mesmo a aparecer de forma indiferenciada, só se

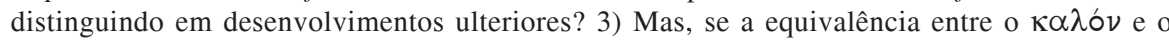
$\alpha \gamma \alpha \theta \dot{b} v$, que fica dada por assente no diálogo preliminar entre Sócrates e Agatão, é na verdade frágil, que outra perspectiva deve corrigi-la - ou seja, em última análise, em que consiste a

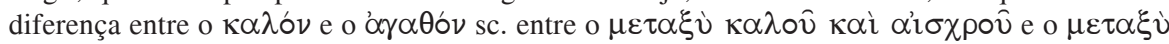

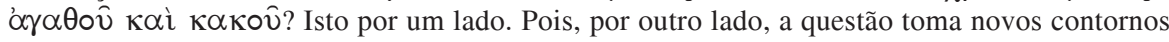
se considerarmos os desenvolvimentos da última parte do discurso de Sócrates/Diotima, onde

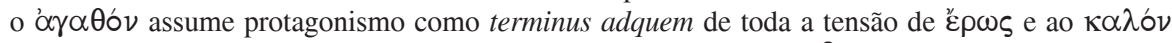

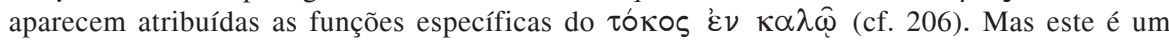
aspecto que já não cabe aqui considerar. Sobre o problema das relações entre os dois pares

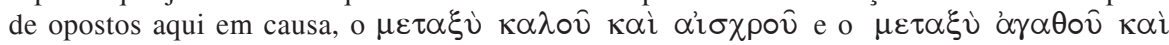

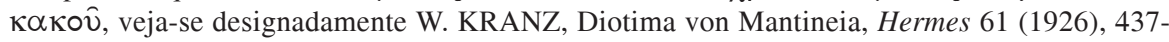
-447, em especial 440ss., H. NEUMANN, Diotima's Concept of Love, American Journal of Philology 86 (1995), 33-59. 
possibilitam parecem corresponder como que a pequenas ilhas perdidas num mar de acesso de outro tipo (de um acesso que se inculca justamente muito mais do que mero acesso $\mu \varepsilon \tau \alpha \xi u ́$ : parece decididamente um acesso já em $\pi$ ópos - na plenitude do $\pi$ ópos). Daí resulta globalmente, quando lemos o discurso de Sócrates/Diotima, a impressão de que o acesso intermédio constituirá, sem dúvida, uma possibilidade da forma como nós somos - uma possibilidade que nos permite ter relações mesmo com aquilo que se situa para lá dos limites do acesso de que de cada vez já dispomos (e que também permite tomar essas relações como ponto de partida para uma expansão do próprio acesso), sim, mas que, no fundo, não tem grande peso na própria conformação do acesso que, de todo o modo, sempre já temos e daquilo a que acedemos nele.

Todavia, se confrontarmos o discurso de Diotima com aquilo que encontramos no resto do corpus platonicum, verificamos que não é bem assim - que é, na verdade, muito

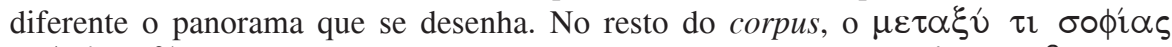

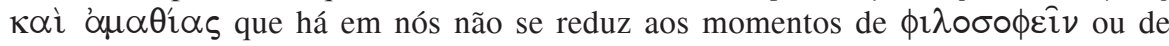
procura, antes inclui também todo o complexo daquilo a que, em diversos textos, Platão chama $\delta \delta \xi \alpha$. Ora, para caracterizar muito brevemente o que isso significa, podemos dizer que significa aquilo que tantas vezes se acha posto em cena nos diálogos platónicos: que o próprio "alfabeto" de determinações a que recorre a apresentação que temos das coisas está constituído de tal modo que, no seu uso habitual, parece inteiramente evidente e dominado (parece justamente não ter nada de $\pi \varepsilon v i ́ \alpha$, antes corresponder inteiramente a $\pi \delta$ ó $)^{72}$; porém, se sujeitarmos a exame cada uma dessas determinações, acabamos por verificar que não só envolvem problemas (e, portanto, uma certa componente de $\pi \varepsilon v i ́ \alpha)$ mas, de facto, pura e simplesmente não sabemos a que correspondem (quer dizer: a componente de $\pi \varepsilon v i ́ \alpha$ que ainda envolvem limita muito seriamente e põe em causa aquilo que também têm de $\pi$ ópos). Por outras palavras, o que aparece desenhado no corpus platonicum é que o referido "alfabeto" (que habitualmente parece tão claro e evidente) se revela, afinal, como um "alfabeto" ainda a precisar de ser decifrado - e ainda a precisar de ser decifrado porque cada um dos seus elementos de facto ainda não faz mais do que consignar (e remeter para) uma incógnita. Assim, a situação em que estamos relativamente a esse "alfabeto de determinações" (e, portanto, a respeito de tudo

72 Ao falarmos aqui de um "alfabeto" de determinações, o que está em causa é o facto de não acontecer que a multiplicidade daquilo que temos apresentado esteja constituída de tal modo que cada um dos seus momentos se ache preenchido por determinações absolutamente originais, que só apareçam nesse momento e não mais se repitam. O que sucede é, muito pelo contrário, que há um conjunto finito de determinações (com um cardinal incomensuravelmente mais pequeno do que o daquilo que se tem apresentado) que se repetem indefinidamente constituindo assim, por variação de combinação, a imensa diversidade daquilo que aparece. Trata-se de algo análogo àquilo que se passa na constituição de uma língua - e, de facto, na constituição de todas as línguas (mortas, vivas e possíveis) e de todos os enunciados possíveis em todas as línguas (ou seja, em toda a "Biblioteca de Babel") - a extraordinária diversidade de tudo isso é integralmente constituída por combinatória de um "alfabeto" de vinte e tal elementos! 
aquilo que nos aparece apresentado segundo esse "alfabeto" de determinações ou "escrito" nele) é uma situação em que já estamos na pista daquilo de que se trata, sim - com notícia disso, voltados para isso, etc. - mas, por outro lado, ainda sem conseguirmos chegar mesmo "lá", compreender que determinações são essas, a que é que correspondem. Ora, o que isto quer dizer é que estamos em relação ao próprio "alfabeto" em que se acha "escrita" toda a apresentação de que dispomos (ou melhor, em relação àquilo que é fixado por esse alfabeto) exactamente naquela forma de acesso intermédio que possibilita a procura - quer dizer, naquele acesso que já põe a descoberto algo, mas, apesar de o pôr a descoberto, ao mesmo tempo ainda o deixa escondido (em recusa e transcendente à apresentação que põe em contacto com ele). Por outras palavras, segundo o que vem descrito no corpus platonicum, o maciço do acesso habitual (aquele que se inculca já como $\pi$ ópos e como algo muito superior ao $\phi 1 \lambda \circ \sigma \circ \phi \varepsilon i ̂ v$ e ao acesso intermédio que o possibilita) encontra-se de facto muito aquém de onde já julga estar - e na verdade a tal ponto aquém e longe disso que também ele não passa de um acesso de tipo $\mu \varepsilon \tau \alpha \xi \hat{v}^{73}$. Mais: segundo o que vem descrito no corpus platonicum, esse maciço de acesso que parece muito superior ao acesso intermédio é na verdade um acesso de tipo $\mu \varepsilon \tau \alpha \xi \hat{v}$ ainda menos eficaz do que o $\phi \imath \lambda \circ \sigma \circ \phi \varepsilon i ̂ v$ e o acesso intermédio que o possibilita. Em suma, segundo o que vem descrito no corpus platonicum, o maciço do acesso habitual não equivale a mais do que um acesso de procura mascarado ou a um acesso intermédio que não se compreende como tal - e que, por estar mascarado, por não se compreender como acesso intermédio, ainda é menos $\pi \delta$ ó procura $^{74}$.

${ }^{73}$ Para usar a linguagem a que Platão recorre no final do livro V da Respublica, o "alfabeto" de determinações com que está "escrito" o texto da apresentação que temos pretende proporcionar conhecimento ( $\gamma \nu \omega \omega \mathrm{\omega} \varsigma)$, ou seja, pretende acompanhar, de forma adequada

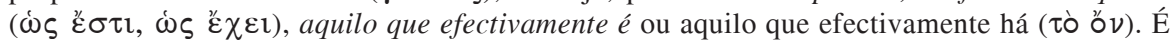
essa a forma de $\pi$ ópo̧ que habitualmente parece já estar adquirida no acesso habitual: o "alfabeto" de determinações em que se acha "escrita" a apresentação de que dispomos e o "alfabeto de determinações" em que se acha escrita "a própria realidade" são o mesmo ou correspondem um ao outro - e os "textos" escritos nesses dois "alfabetos" podem coincidir e coincidem. Mas, uma vez sujeito a exame, o que se apura é que tal pretensão na verdade não tem fundamento - e que o "alfabeto de determinações" em que está "escrita" a apresentação de que dispomos é um "alfabeto" problemático (desde logo porque não se consegue encontrar a que é que corresponde propriamente cada um dos seus elementos). Nessa medida, a situação

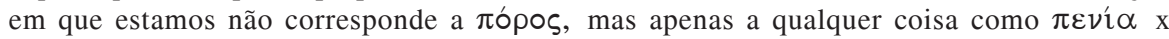

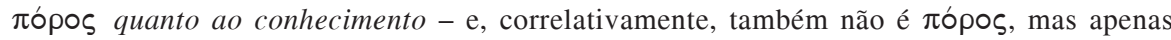
$\pi \varepsilon \nu i \alpha$ x $\pi \delta$ pos quanto ao pretenso ö $\nu$ a que o acesso disponível leva.

${ }^{74} \mathrm{Se}$ o acesso tem apenas um carácter correspondente a $\pi \varepsilon v i ́ \alpha \times \pi$ x $\pi$ o erradamente compreendido como sendo já plenamente $\pi \delta$ $\rho \circ \zeta$, então não envolve apenas a componente de encobrimento (falta de acesso ou escondimento: a componente de $\pi \varepsilon v i ́ \alpha$ ) que também é própria do $\phi \imath \lambda \circ \sigma \circ \phi \varepsilon i ̂ \nu$ (sc. da situação de acesso em que a procura ainda é precisa e possível). Além dessa, envolve ainda uma segunda componente de encobrimento (de falta de acesso ou escondimento): aquela que oculta o facto de se tratar justamente apenas de um acesso em regime de $\pi \varepsilon v i ́ \alpha$ x $\pi$ ópos - e não de um acesso já com o carácter de $\pi$ ópos, como 
Ora, se é efectivamente assim, se há essa forma de acesso intermédio não-interrogativo (que não é senão um acesso intermédio interrogativo que não se reconhece como tal $^{75}$ ) e se efectivamente acontece que o maciço do acesso que

parece ser. Ou seja, neste caso, o acesso $\mu \varepsilon \tau \alpha \xi u ́$ inclui ainda um escondimento (um encobrimento ou uma $\pi \varepsilon v^{\prime}(\alpha)$ adicional, que "tapa" a própria situação em que efectivamente está, criando a aparência de ela ser mais do que efectivamente é e de alcançar mais do que efectivamente alcança. Por outro lado, este acréscimo de encobrimento ou de $\pi \varepsilon v^{\prime} \alpha$ traduz-se justamente também num acréscimo de escondimento ou encobrimento do próprio "objecto" em causa - ou seja, disso que está apresentado pelo acesso $\mu \varepsilon \tau \alpha \xi \hat{v}$. Com efeito, a apresentação $\mu \varepsilon \tau \alpha \xi \hat{v}$ que desencadeia

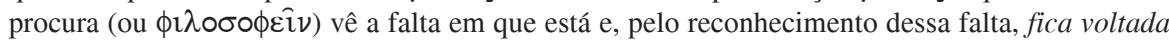
para aquilo que lhe falta e em tensão para isso. Pelo contrário, se um acesso ainda meramente $\mu \varepsilon \tau \alpha \xi \hat{v}$ se toma por algo já correspondente a $\pi$ ópos, então frustra, desactiva ou desvirtua o contacto que, enquanto $\mu \varepsilon \tau \alpha \xi \hat{v}$, também já tem com aquilo que ainda lhe falta (quer dizer, com isso mesmo que apresenta, mas que continua a escapar-lhe e a ser transcendente a ele). Nessa medida, o acesso $\mu \varepsilon \tau \alpha \xi \dot{v}$ que se toma por algo já correspondente a $\pi$ ópo como que se "enquista" e se fecha completamente em si - constituindo assim a forma paralisada daquilo que o $\mu \varepsilon \tau \alpha \xi u ́$ constitutivamente tem de inquieto e de dinâmico (i.e. daquilo que todo o $\mu \varepsilon \tau \alpha \xi u ́ v$ constitutivamente tem de remissão e de tensão para lá de si: para o respectivo $\pi$ ópo̧). Também por este motivo - porque "volta as costas" a isso mesmo que apresenta ou ao seu próprio objecto - todo o acesso $\mu \varepsilon \tau \alpha \xi$ v́ que se toma já por $\pi$ ópos tem uma natureza tal que esse seu tomar-se-por-mais-do-que-efectivamente-é só o torna ainda menos, só agrava a componente de

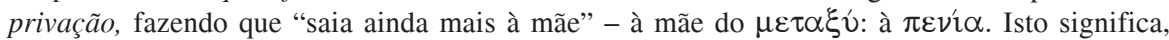
por outro lado, três coisas. Em primeiro lugar, a todo e qualquer acesso intermédio que não se

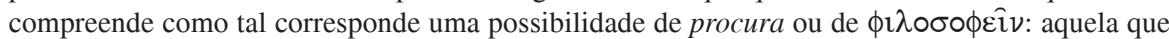
está embargada pelo facto de não se compreender como tal, mas possibilitada pelo facto de se

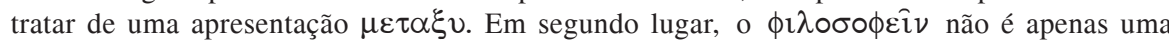
possibilidade implicada no acesso $\mu \varepsilon \tau \alpha \xi u$ que ilusoriamente se toma por algo já equivalente a $\pi$ ópos. É muito mais do que isso: é, por assim dizer, a verdade disso. Pois, se o acesso $\mu \varepsilon \tau \alpha \xi \hat{~} v$ anular a ilusão em que está embarcado, então reconhece-se como acesso onde a relação

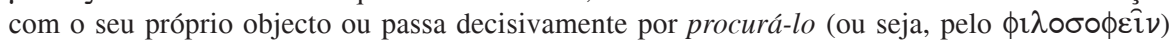
ou então fica desactivada, frustrada, "curto-circuitada" - perdendo-se longe dele e em dissolução do contacto com ele. Em terceiro lugar, se todo o acesso de que dispomos (e o próprio "alfabeto" que o compõe) corresponde a um acesso $\mu \varepsilon \tau \alpha \xi u ́$ que só ilusoriamente se toma por $\pi$ ópos, então todo o acesso em que está constituído um ser humano é - em todos e cada um dos seus

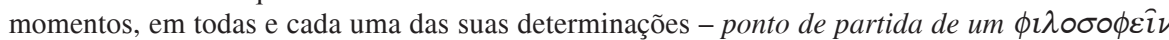
(quer dizer, de um outro acesso) possível, sem o qual esconde (tanto quanto mostra) aquilo que já põe a descoberto. Quer dizer: o acontecimento de acesso ou apresentação que faz o humano é susceptível de ser integralmente convertido em $\phi 1 \lambda \circ \sigma \circ \phi \varepsilon i ̂ \nu$ - e não apenas é integralmente susceptível de ser convertido em $\phi 1 \lambda \circ \sigma \circ \phi \varepsilon i ̂ \nu$ mas tem uma constituição tal que, se não o for, fica desactivada, frustrada ou "curto-circuitada" a relação que tem com isso mesmo para que aponta. E, deste modo, a apresentação que nos constitui é, em tudo, uma apresentação em remissão para lá de si e está, em tudo, como que globalmente "grávida" de uma ultrapassagem de si mesma.

75 Chamamos aqui acesso intermédio não-interrogativo àquele que não resulta numa procura, numa tensão para a sua ultrapassagem (antes fica instalado e "enquistado" em si mesmo como

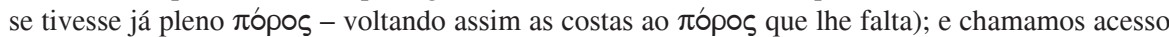
intermédio interrogativo àquele que, pelo contrário, está dominado pela consciência do que ainda tem de $\pi \varepsilon v^{\prime} \alpha$ e, por isso, tende para fora de si: para o $\pi$ ópos que lhe falta. 
habitualmente se inculca como $\pi$ ópos (como muito mais do que um acesso meramente $\mu \varepsilon \tau \alpha \xi \tilde{v})$ é, na verdade, mero acesso intermédio não-interrogativo e, portanto, ainda menos (se assim se pode dizer, ainda mais fortemente $\mu \varepsilon \tau \alpha \xi \hat{v}$, ainda mais retido e ainda mais longe de um efectivo $\pi \delta$ ós em matéria de acesso) do que o próprio acesso que possibilita a procura enquanto tal, então o $\mu \varepsilon \tau \alpha \xi \hat{v} \tau \imath$

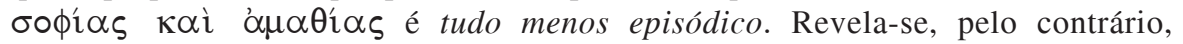
coextensivo a tudo quanto aparece (a todo o acesso que habitualmente se inculca como sendo já muito mais do que $\phi \mathbf{i} \lambda \circ \sigma o \phi \varepsilon i ̂ v$ e a todos os seus correlatos). Ou seja, nessas condições é a totalidade da apresentação de que dispomos e a totalidade do que se acha apresentado nela (quer dizer: é pura e simplesmente tudo aquilo com que estamos em contacto) que fica reduzido a não mais do que $\mu \varepsilon \tau \alpha \xi v^{76}$.

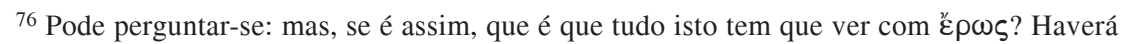
um nexo entre isto e ع̌ $\rho \omega \varsigma$ porque, como apontámos, tudo isto significa que todos e cada um dos momentos da apresentação de que dispomos estão constituídos de tal modo que são o ponto de partida de uma procura ou de um $\phi \mathbf{i} \lambda \circ \sigma \circ \phi \varepsilon i ̂ v$ possível? Na verdade não é apenas isso. Acontece antes que é assim (e todos os momentos da apresentação que temos constituem efectivamente o ponto de partida de um $\phi$ i $\lambda \circ \sigma o \phi \varepsilon i ̂ v$ possível) justamente porque a apresentação ou o acesso em que estamos constituídos tem o carácter de uma manifestação a meio caminho, como que encalhada a meio - semi-feita. Isto não tanto porque o acesso que temos deixa isto e aquilo (ou mesmo até "mundos e fundos") fora do seu âmbito, quanto porque a forma que tem de pôr a descoberto isso mesmo que já põe a descoberto o deixa na verdade ainda escondido, inacessível, por compreeender (e, nesse sentido, por descobrir). Este é que é o aspecto decisivo: segundo a descrição que encontramos desenhada no corpus platonicum, toda a apresentação de que dispomos produz apenas uma semi-compreensão ou um semi-acompanhamento daquilo que apresenta - algo que não consegue dominar e perceber aquilo com que põe em contacto (e que de facto ainda menos o domina e o consegue perceber quando julga entendê-lo na perfeição e embarca numa evidência de domínio). Pois a própria evidência de posse e de domínio provém de inadvertência - de um defeito de acuidade na relação com as próprias determinações que se apresentam (um defeito tal que, por outro lado, a própria anfibolia do acesso $\mu \varepsilon \tau \alpha \xi \hat{v}$ permite detectá-lo, levando assim à descoberta de que as determinações em causa se mantêm fora de alcance e só por inadvertência podem valer como captadas e transparentes). Numa palavra, tal como se encontra descrito no corpus platonicum o acesso em que estamos constituídos é um acesso em tudo (em todos e cada um dos seus momentos) atravessado entre a descoberta e o escondimento, com tanto de um quanto do outro - e isto não em partes separadas, antes de tal modo que o que tem de uma está inteiramente perpassado e internamente contido (contrariado) pelo que também tem do outro. Em suma, a apresentação ou o acesso que é constitutiva do Humano é em tudo uma manifestação embargada, que fica aquém do seu próprio alvo. E assim, enquanto $\mu \varepsilon \tau \alpha \xi u ́$, toda a apresentação que temos (e tudo aquilo a que se acede nela) acaba por ter a forma de uma realidade intrinsecamente em tensão, intrinsecamente desiderativa. De resto, esta descoberta de que a própria apresentação ou o próprio acesso enquanto tal tem a forma de

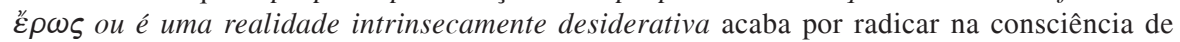
que o que está em causa no próprio acesso ou na apresentação enquanto tal é aquela modalidade específica de realidade-em-tensão ou de realidade intrinsecamente desiderativa (intrinsecamente $\mu \varepsilon \tau \alpha \xi \hat{v}$, intrinsecamente $\pi \varepsilon v i \alpha$ x $\pi$ ópo૬) que é o pretender ser - o pretender ser no sentido em que uma realidade (a realidade própria da apresentação e do apresentado) 
Só quando se percebe isto que aqui muito sucintamente acabamos de esboçar em relação ao carácter meramente $\mu \varepsilon \tau \alpha \xi \hat{v}$ de todo o acesso de que dispomos (e, portanto, também ao carácter meramente $\mu \varepsilon \tau \alpha \xi \hat{v}$ de tudo aquilo a que se acede nele), é que ficam criadas as condições para medir bem as implicações e o alcance do peculiar retrato do humano que se acha traçado quando o discurso de Sócrates/ Diotima nos apresenta como sendo uma realidade $\mu \varepsilon \tau \alpha \xi v$. Pois a partir daqui percebe-se bem que não se trata só de um retrato de aspectos do humano ou de uma parte do humano, nem tampouco se trata só de um retrato de uma parte daquilo com que estamos em contacto, mas antes de um retrato de todo o plano em que nos encontramos e de tudo nele - de tal modo que, por um lado, estamos como que integralmente formados por $\mu \varepsilon \tau \alpha \xi \hat{v}$, mergulhados e retidos em $\mu \varepsilon \tau \alpha \xi \hat{v}$, rodeados de $\mu \varepsilon \tau \alpha \xi u$ "por todos os lados" (e o $\mu \varepsilon \tau \alpha \xi v$ é o modo-de-ser de tudo aquilo com que lidamos) e, por outro lado, em cada um dos momentos daquilo que somos (com que lidamos, que nos rodeia, etc.) é identificável não apenas um aspecto de condição intermédia (de fusão de $\pi \varepsilon v i ́ \alpha$ e $\pi \delta$ óo , de constituição intrinsecamente desiderativa, etc.), mas de facto uma multiplicidade deles - e o acontecimento que nós próprios somos é, em todos e cada um dos seus momentos, multiplamente $\mu \varepsilon \tau \alpha \xi \tilde{v}$.

O terceiro problema que aqui importa referir, sem discutir os seus complexos meandros, prende-se com a tese daqueles que sustentam que a descrição do ente em que se juntam as diferentes modalidades de $\mu \varepsilon \tau \alpha \xi \hat{v}$ mencionadas no discurso de

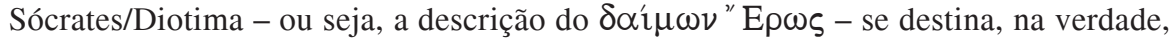

pretende chegar a (e ser em si) outra: a própria realidade daquilo que procura apresentar. Quer dizer, na forma como estão constituídas em nós (não se discute aqui se pode alguma vez ser de outro modo), a apresentação e o seu apresentado são no modo do pretenderem ser (mais precisamente naquele modo-de-ser que é o de algo que consiste justamente em pretender-ser-algo diferente-do-que-é). Trata-se de um ser tal que, no seu caso, عîv $\alpha 1=\beta \circ u ́ \lambda \varepsilon \sigma \theta \alpha 1$

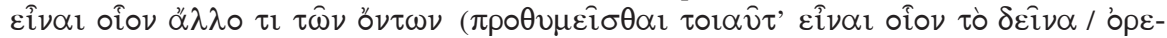

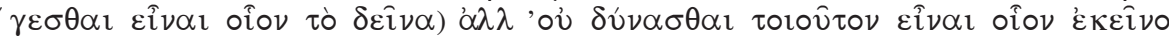

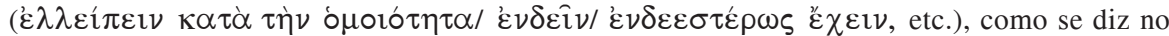
Phaedo 73css., para caracterizar o modo-de-ser próprio da imagem. Quanto ao problema, que também se pode levantar, sobre a legitimidade de incluir na discussão do discurso de Sócrates/ Diotima estes elementos relativos ao $\mu \varepsilon \tau \alpha \xi u ́$ não interrogativo, que não estão referidos no próprio discurso, há que responder, sucintamente, o seguinte. Se não for recebido em registo meramente doxográfico, o discurso de Sócrates/Diotima levanta a questão de saber se o acesso intermédio que expressamente refere (o acesso que possibilita o $\phi \imath \lambda \circ \sigma \circ \phi \varepsilon \hat{\imath} \nu$ ) é a única forma

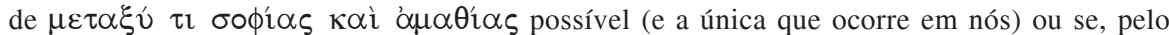

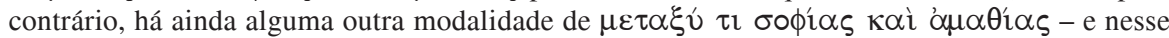
caso qual. Ora, a resposta a essa pergunta está dada, com toda a nitidez, no resto do corpusplatonicum e tem, no fundamental, o teor de que aqui tentámos dar uma ideia. Para uma análise um pouco mais detida desta constelação de problemas, que tivemos de referir em descrição puramente formal - quer dizer, deixando de fora o decisivo: a discussão de a que ponto é efectivamente assim, como Platão sugere - cf. M. J. de CARVALHO, Problemas

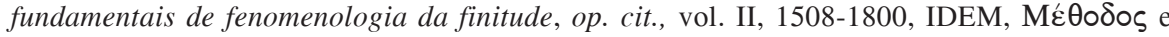
íđó $\theta \varepsilon \sigma ı \varsigma$ - o problema do pressuposto na fundação platónica da filosofia, op. cit., 23-38. 
a retratar Sócrates. ${ }^{77} \mathrm{O}$ estritamente indispensável que aqui cabe dizer sobre esta matéria pode resumir-se no seguinte. Como resulta do exposto, na descrição traçada por Diotima quando fala do $\mu \varepsilon \tau \alpha \xi \hat{v}$, do $\delta \alpha i \mu \omega \nu^{\prime \prime}$ E $\rho \omega \varsigma$, etc., parece estar em causa muito mais do que Sócrates. Pois, se não nos enganamos, está em causa nada menos do que uma descrição da própria constituição do humano. Sucede, porém, que, se assim é, isso não significa que não se trate também de um retrato de Sócrates - não pura e simplesmente porque Sócrates também é um ser humano (e, por isso, também se caracteriza por este mesmo modo-de-ser) mas porque, para além disso, Sócrates constitui, no corpus platonicum, como que o emblema da condição humana inteiramente advertida para si mesma - ou, como também podemos dizer, o emblema do próprio $\mu \varepsilon \tau \alpha \xi \hat{v}$ em plena apropriação de si mesmo.

Acontece, entretanto, que contra tudo isto se pode levantar uma objecção que põe em causa a correspondência entre o que acabamos de dizer e aquilo que se encontra no texto do Symposium. Pode, com efeito, contrapor-se que toda esta compreensão das palavras de Diotima como caracterização do Humano vai ao arrepio do que aparece expressamente dito na sua intervenção, mais precisamente onde

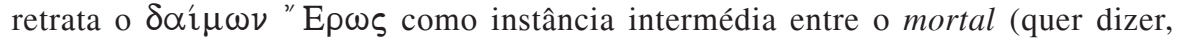
segundo tudo indica: o humano) e o imortal. ${ }^{78}$ Diotima parece assim dizer, com todas as letras, que pelo menos este aspecto do $\mu \varepsilon \tau \alpha \xi u ́$ se situa claramente acima do humano e que, pelo menos a este respeito, o humano não é algo de intermédio, antes pertence a um dos extremos - ou, mais precisamente, fica, de facto, aquém do intermédio, abaixo dele.

Porém, este tipo de argumentação falha redondamente o decisivo. Pois, em primeiro lugar, como se viu, a própria caracterização da vida ou do $\phi 1 \lambda \circ \sigma \circ \phi \varepsilon i ̂ v$ como $\mu \varepsilon \tau \alpha \xi u ́$ mostra com toda a nitidez que Diotima não fica presa a essa perspectiva. O discurso passa do registo mítico-religioso, que no princípio toma do discurso de Agatão, para um registo onde ganha mais peso a análise de fenómenos. E, em segundo lugar, vendo bem, se juntarmos todas as peças, aquilo que Diotima evidencia é precisamente a inexistência do Humano enquanto algo encapsulado, absolutamente fechado em si - quer dizer, a sua inexistência como pólo isolado, separado do que o ultrapassa, inteiramente contido nas suas próprias fronteiras ${ }^{79}$. Ou seja, Diotima acentua que o Humano é intrínseca e multiplamente $\mu \varepsilon \tau \alpha \xi \hat{v}$, i. e., algo que se caracteriza precisamente por diversos modos de não estar contido

77 Seria excesivamente longo referir aqui os vários autores que sustentaram este tipo de tese e as diversas formas como a fundamentaram e entenderam a correspondência entre os

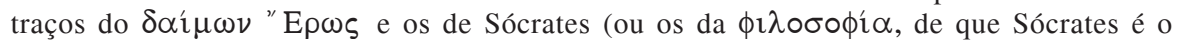
emblema). A tradição desta interpretação é muito antiga e remonta pelo menos até Máximo de Tiro - cf. G. L. KONIARIS (ed.), Maximus Tyrius Philosophumena: ÄéáëYî́åéó, Berlin, de Gruyter, 1995, XVIII, p. 223.

${ }^{78}$ Cf. 202d5-202e1 e o que a este respeito se viu supra.

79 Que é o modo-de-ser próprio dos "extremos", quer dizer, daquilo que corresponde simplesmente a $\pi \varepsilon \nu i ́ \alpha$ ou a $\pi$ ópos. Os extremos é que estão constituídos de tal modo que cada um deles é ő $\pi \varepsilon \rho$ है $\sigma \tau \imath \nu$. Cf. supra nota 57. 
nos seus próprios limites, mas antes atravessado sobre eles, aberto e ligado àquilo que o excede: sempre já "semi-levado" a isso, em relação com isso, a-caminho disso. E é precisamente esse tipo de constituição não presa àquilo que estritamente é (não fechada no limite do que é seu, passada para lá dele, atravessada) - é este "para-lá"-(este "superior")-presente-no-próprio-seio-da-realidade-humana, este já-estar-em-ligação-com-o-que-ultrapassa ou já-estar-em-ligação-com-o-que-falta-que, em última análise, é retratado quando Diotima fala de um $\delta \alpha \hat{\imath} \mu \omega \nu$, bem como do

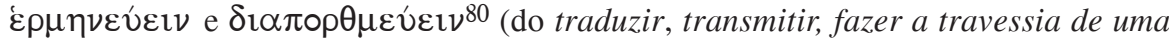

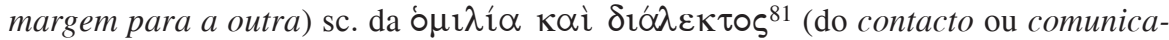
ção) que lhe compete. Em suma, na descrição de Diotima, o Humano é, por natureza, mais que humano. Ou, como também se pode dizer, o humano não tem a natureza de um "extremo" - que pura e simplesmente é o que é - mas sim a de um $\mu \varepsilon \tau \alpha \xi v ́$ - que está constitutivamente atravessado para lá de si. E a referência ao $\delta \alpha i ́ l \mu \omega \nu$ é uma referência ao carácter intrinsecamente " $\delta \alpha i \mu \omega \nu$-íaco"82 do Humano enquanto tal.

Para perceber bem tudo isto, importa ter presente que, à semelhança do que

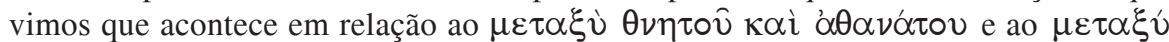

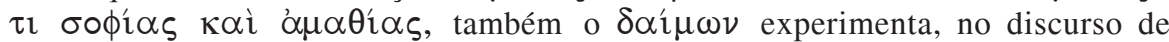
Sócrates/Diotima, uma mudança de caracterização - uma mudança tal que aquilo que a princípio aparece com um determinado "rosto" acaba, depois, por surgir com uma identificação diferente. Assim, quando primeiro entra em cena no discurso, o

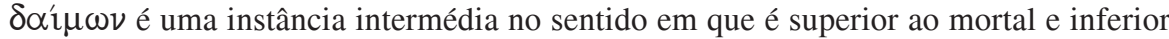
ao imortal. Distingue-se pelo exercício das funções de mediação que oportunamente pusemos em relevo, mas de tal modo que, em última análise, essas funções de mediação têm um carácter puramente adjectivo em relação àquilo que o próprio $\delta \alpha i ́ \mu \omega \nu$ é - e isso que o próprio $\delta \alpha i ́ l \mu \omega \nu$ é não está concebido como algo com uma constituição “atravessada”, internamente rasgado por uma tensão entre opostos, desavindo consigo mesmo, etc. Por outras palavras, quando entra em cena no discurso de Sócrates/Diotima, o $\delta \alpha i ́ l \omega \nu$ ainda não está compreendido como algo constitutiva e intrinsecamente $\mu \varepsilon \tau \alpha \xi v$. Exerce o $\varepsilon \rho \mu \eta v \varepsilon v ́ \varepsilon \imath v$ e $\delta \imath \alpha \pi \circ \rho \mu \varepsilon v ́ \varepsilon \imath v$, a ó $\mu \imath \lambda i ́ \alpha$ $\kappa \alpha_{1} \delta i o ́ \lambda \varepsilon \kappa \tau O \zeta$ de que se falou, mas não é ele mesmo constituído como um cruzamento de $\pi \varepsilon v i ́ \alpha$ e $\pi$ ópos: não é ele mesmo, em si mesmo, feito de $\varepsilon \rho \mu \eta v \varepsilon v ́ \varepsilon \imath \nu$ e

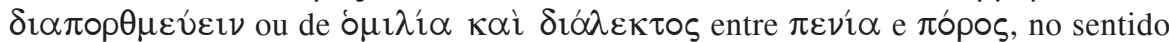
referido. Ou, dito de outro modo, quando entra em cena no discurso de Sócrates/ Diotima, o $\delta \alpha \hat{\imath} \mu \omega \nu$ exerce funções de mediação mas na verdade possui aquilo que nas páginas precedentes designámos como o modo-de-ser de um "extremo" (de tal modo que é ǒ $\pi \varepsilon \rho ~ \varepsilon ้ \sigma \tau \imath$ - ou seja, pura e simplesmente é a sua própria determinação e não comporta nada da complicação interna, da distância em relação a si mesmo, da inquietação, etc., que vimos serem características do modo-de-ser intermédio retratado no discurso). De facto, nessa apresentação inicial do $\delta \alpha i ́ f \omega \nu$, todas as
$80202 \mathrm{e} 3$.
$81203 \mathrm{a} 3$.
82 No peculiar sentido que a noção adquire a partir do discurso de Sócrates/Diotima. 
instâncias referidas (quer os deuses, quer os mortais, quer o próprio $\delta \alpha \hat{\imath} \mu \omega \nu$ ) ainda estão compreendidas justamente dessa forma - como algo cuja constituição é a de um "extremo". Mas, sendo assim, o desenvolvimento do discurso de Sócrates/ Diotima traz consigo uma significativa modificação: deixa-se para trás este terreno mítico-religioso, passa-se justamente à consideração de formas de realidade que são constitutiva, intrinsecamente $\mu \varepsilon \tau \alpha \xi \hat{v}$ e correspondem, no seu próprio modo-de-ser, a algo de intermédio entre o mortal e o imortal, a algo de intermédio entre o saber e o não-saber, etc. Ora, o decisivo aqui é que esta mudança deixa para trás o $\delta \alpha i ́ f \omega \nu$ no sentido mais estritamente mítico-religioso (e deixa também para trás o $\delta \alpha i ́ \mu \omega \nu$ enquanto possui o modo-de-ser de um "extremo") mas recupera (e, se assim se pode dizer, radicaliza ${ }^{83}$ ), no novo registo em que passa a concentrar-se, alguns traços fundamentais da determinação do $\delta \alpha \hat{\imath} \mu \omega \nu$ que ficaram desenhados no registo que abandona: o $\delta \alpha \hat{\imath} \mu \omega \nu$ enquanto aquilo que faz a ponte, o $\delta \alpha \hat{\imath} \mu \omega \nu$ responsável

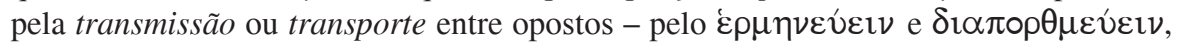

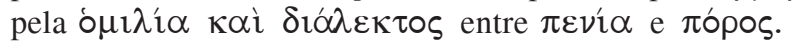

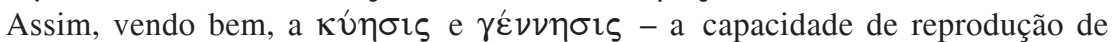

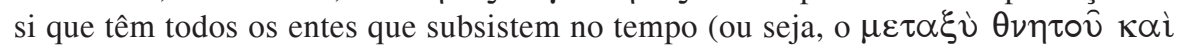

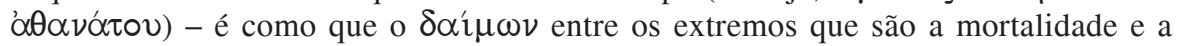
imortalidade, no sentido oportunamente definido. Pois é algo que faz ponte qualquer coisa como uma passagem, uma tradução, travessia ou transporte (um

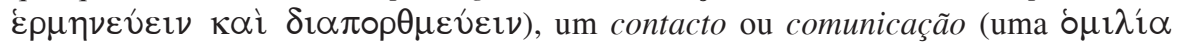
$\kappa \alpha \grave{i} \delta i o ́ \lambda \varepsilon \kappa \tau O \varsigma$ ) entre a mortalidade e a imortalidade ${ }^{84}$. Trata-se justamente de um mortal mais do que mortal, de algum modo aberto e ligado àquilo que o excede e, nesse sentido, atravessado para lá de si. Do mesmo modo, o acesso intermédio

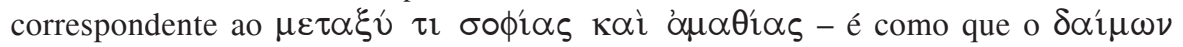
entre os extremos que são o puro e simples saber e a pura e simples ignorância. Pois é algo que faz ponte - qualquer coisa como uma passagem, uma tradução,

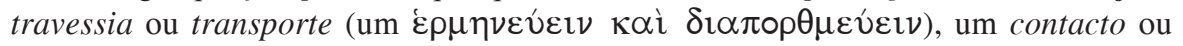

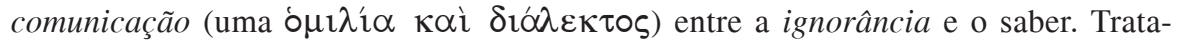
-se justamente de um não-saber mais do que não-saber, de algum modo aberto e ligado àquilo que o excede e, nesse sentido, atravessado para lá de si. E, em terceiro lugar, se vale alguma coisa o paralelismo que o discurso de Sócrates/Diotima aponta e que já procuraremos ver melhor, então também a instância intermédia entre o belo

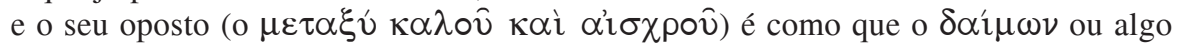
que faz ponte - qualquer coisa como uma passagem, uma tradução, travessia ou

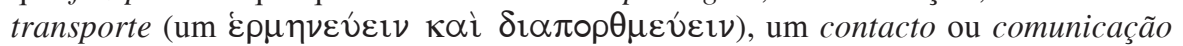

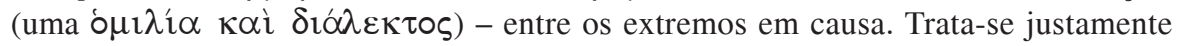

83 Pode-se falar de radicalização porque, para usar a fórmula a que há pouco recorremos, as funções próprias do $\delta \alpha i ́ \mu \omega \nu$ deixam de ser meramente adjectivas relativamente a uma realidade em cuja constituição não intervêm e passam, pelo contrário, a ser "substantivas" e a intervir nessa constituição.

${ }^{84}$ E é-o substantivamente, para usar a linguagem da nota anterior. 
de uma ausência do belo mais do que ausência do belo - de algum modo aberta e ligada àquilo que a excede e, nesse sentido, atravessada para lá de si.

Mas mais: de tudo isto resulta, finalmente, que o ente constituído pela confluência destas várias modalidades de $\mu \varepsilon \tau \alpha \xi \dot{v}$ - quer dizer, o ser humano (justamente aquele ente que nós somos) - é como que o $\delta \alpha i ́ \mu \omega \nu$ dos vários opostos em causa em todas elas (um ente que simultaneamente está atravessado e faz ponte ou é travessia, contacto ou comunicação entre todos esses opostos: um ente que, no próprio modo como está constituído, exerce todas essas funções mediadoras). De sorte que se pode dizer a respeito deste ente exactamente o que, no passo citado,

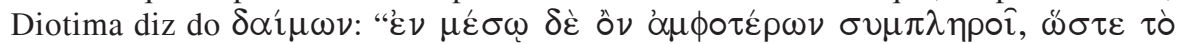

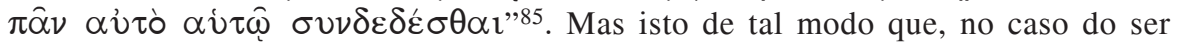
humano, estamos a falar de algo em que tais palavras assentam não apenas em relação a uma só oposição (ou a um só par de opostos) mas em relação a diversas oposições cruzadas entre si. Pois o Humano é ao mesmo tempo $\delta \alpha i ́ \mu \omega \nu$ (uma

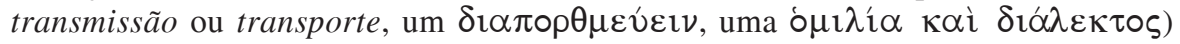
entre a imortalidade e a mortalidade, entre o saber e o não-saber e entre o belo e o seu oposto. Ou seja, trata-se de um ente composto por qualquer coisa como uma multiplicidade ou acumulação de faltas mais do que faltas, todas de algum modo abertas e ligadas àquilo que as excede, atravessadas para lá de si. Ou, como também podemos dizer (resumindo assim aquilo para que o discurso de Sócrates/ Diotima aponta), o ser humano é constitutivamente entre: entre a mortalidade e a imortalidade, entre o não-saber e o saber, entre a ausência de belo e o belo a ser todos estes "entres" ou a ser a conjunção (o "entre") destes vários "entres" 86.

Dito isto, há finalmente ainda um ponto que importa pôr em relevo a respeito da noção de $\mu \varepsilon \tau \alpha \xi \hat{v}$ e da caracterização do Humano como $\mu \varepsilon \tau \alpha \xi \hat{v}$ (ou da fórmula Humano $=\ddot{\varepsilon} \rho \omega \varsigma=\mu \varepsilon \tau \alpha \xi \hat{v}=\delta \alpha \hat{\imath} \mu \omega \nu$ que, como se tentou mostrar, encontramos traçada no discurso de Sócrates/Diotima). Se o $\mu \varepsilon \tau \alpha \xi v ́$ é uma instância intermédia constitutivamente relativa a um $\pi$ ópos (e se o modo-de-ser do $\delta \alpha \hat{i} \mu \omega \nu$, no sentido proposto no discurso, tem que ver com a presença de algo superior, acima, para lá - com o facto de estarmos constitutivamente atravessados em direcção a isso e termos isso a mover este ainda-aquém-disso que nós somos), nada disto significa que se trate forçosamente de um "mais", de um "acima", de um "para lá" - numa palavra, de um $\pi \delta \rho \rho_{\zeta}$ - que tenha lugar em si mesmo, independentemente do humano. Ou, para usar o esquema conceptual do discurso, não se trata forçosamente de algo que tenha lugar na pura forma de "extremo" - ocorrendo separadamente só por si, na

85 Estando ele no meio, é por seu intermédio que o todo está em ligação (ou entra em ligação) consigo mesmo.

${ }^{86}$ São muito complexas as implicações deste peculiar emprego da noção de $\delta \alpha i ́ \mu \omega \nu$ no discurso de Sócrates/Diotima e a forma como se relacionam com os sentidos da noção no seu uso pré-platónico e platónico. No Apêndice III acentuam-se muito sucintamente alguns aspectos decisivos. 
"olímpica" condição da sua plenitude ${ }^{87}$. Essa é, sem dúvida, uma possibilidade que não há meio de excluir. E podemos mesmo dizer que parece ser aquela para que o discurso de Sócrates/Diotima aponta. Pois tudo nele parece pressupor a ocorrência separada de cada um dos opostos e das instâncias intermédias que os medeiam de tal modo que as instâncias intermédias se situam efectivamente algures entre os respectivos extremos. Mas, por outro lado, para se perceber bem a peculiaridade da

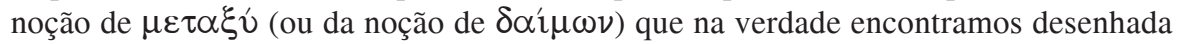
no discurso de Sócrates/Diotima, convém sublinhar que, em última análise, também pode acontecer que esse "mais", "acima", ou "para lá" só tenha lugar como o extremo

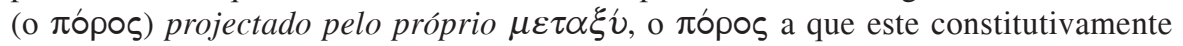
está votado e para que tende, ou o superior que, por sua própria natureza, o $\mu \varepsilon \tau \alpha \xi v$ tem como alvo. Por outras palavras, para haver o $\mu \varepsilon \tau \alpha \xi u$ que nós somos não é indispensável que haja efectivamente, na plenitude de si, o $\pi$ ópos desse $\mu \varepsilon \tau \alpha \xi u ́$. Basta que esse $\pi \delta$ ó $\mu \varepsilon \tau \alpha \xi u ́$ - se assim se pode dizer, como o demandado do $\mu \varepsilon \tau \alpha \xi u ́$. Haja ou não haja algo de correspondente à imortalidade, ao saber ou ao belo, isso tem lugar, de

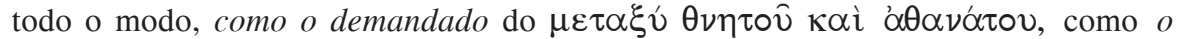

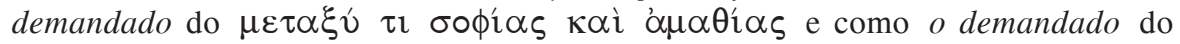

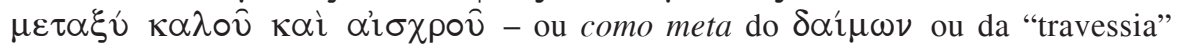
que nós somos - e é precisamente porque isso tem sempre já lugar como demandado e como meta do $\mu \varepsilon \tau \alpha \xi \hat{v}$ ou do $\delta \alpha i ́ \mu \omega \nu$ (e está sempre já inscrito, desse modo, em nós) que se torna relevante saber se tal $\pi$ ópos também tem lugar de outro modo e se alguma vez pode ser alcançado ou é pura e simplesmente uma miragem da própria forma como estamos constituídos.

Este é, como já veremos, um dos aspectos fundamentais da inversão de perspectiva que o discurso de Sócrates/Diotima opera em relação ao discurso de Agatão - uma inversão de perspectiva que, vendo bem, retoma aquela que já estava implicada no discurso de Aristófanes, mas havia sido desfeita ou esquecida por Agatão.

\section{Do Belo como constituinte do Humano: o Humano como $\mu \varepsilon \tau \alpha \xi v$

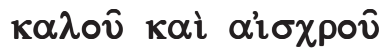

O que vimos desenha com clareza a peculiaridade da perspectiva proposta por Diotima acerca do Belo, quando a) fala de um $\mu \varepsilon \tau \alpha \xi \hat{v} \kappa \alpha \lambda \circ \hat{v} \kappa \alpha i$ $\alpha$ i $\sigma \chi \rho \circ \hat{v}$, ou seja, de algo intermédio entre o Belo e o seu oposto, b) situa ع̌ $\rho \omega \varsigma$ enquanto '̇ $\pi \imath v \mu \mathfrak{i} \alpha$ ou desejo no terreno desse $\mu \varepsilon \tau \alpha \xi \dot{v}$ e, por outro lado, c) inclui a instância

${ }^{87} \mathrm{Ou}$ seja: se o humano é, ao mesmo tempo, $\mu \varepsilon \tau \alpha \xi u ́$ em relação à imortalidade, ao saber e ao belo, isso não significa, forçosamente, que haja efectivamente qualquer coisa como o puro

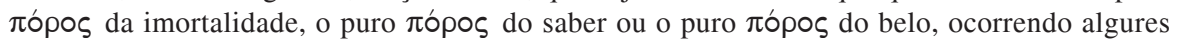
para lá do $\mu \varepsilon \tau \alpha \xi u ́$ que nós próprios somos. 
intermédia entre o Belo e o seu oposto na constelação de instâncias intermédias que, como vimos, descreve como sendo constitutiva do Humano.

Vejamos os aspectos fundamentais que é preciso ter em conta para não perder o fio do novelo.

Em última análise, a inflexão que o discurso de Sócrates/Diotima introduz relativamente ao discurso de Agatão tem que ver com o facto de, como sublinha, a $\varepsilon \pi \imath \theta v \mu \imath \alpha$, enquanto tal, ser uma forma de acontecimento ou realidade com

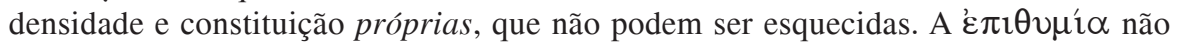
é necessariamente produzida pela presença do $\kappa \alpha \lambda o ́ v$, como uma mera consequência dela, susceptível de ser compreendida apenas nesses termos. A $\varepsilon \pi \imath \theta u \mu i ́ \alpha$ é algo de próprio, que se constitui e tem de constituir por si - de tal forma, aliás, que, sem esse algo de próprio que é a realidade da $\varepsilon \pi \imath \theta u \mu i ́ \alpha$ enquanto tal, o $\kappa \alpha \lambda o ́ v$ não tem condições para exercer o fascínio e o império de que se falou. Pois pode o $\kappa \alpha \lambda$ óv ter tudo aquilo para que aponta a concepção tradicional de $\varepsilon$ है $\omega \varsigma$ como potência exterior, pode reunir em si todos os predicados exuberantemente celebrados no discurso de Agatão, ser o mais extraordinário e o mais maravilhoso que se quiser ainda assim, se não houver algo de outro, próprio, marcado pela forma de ser característica da $\varepsilon \pi \imath \theta v \mu i ́ \alpha$ (por esse peculiar projecto e essa peculiar precisão de

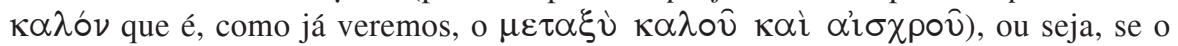
$\kappa \alpha \lambda$ óv não vier responder a nada (a uma sensibilidade em relação a ele, a alguma coisa já de si aberta para ele, dirigida a ele, votada a ele e que de algum modo $o$ reclama), todo o seu fascínio, todo o seu poder será inteiramente vão e de nenhum efeito. Em suma, para ter impacte (para poder invadir, avassalar, etc.), o к $\alpha \lambda$ óv precisa da $\dot{\varepsilon} \pi \imath \theta u \mu i ́ \alpha$, mais precisamente, precisa de ser descoberto por um ente

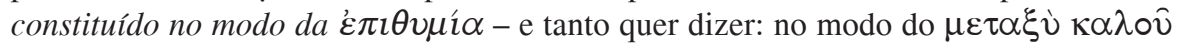

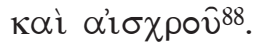

${ }^{88}$ Percebe-se a partir daqui todo o alcance da crítica que o discurso de Sócrates/Diotima faz ao elogio de Agatão. No final da sua intervenção, Sócrates diz que Agatão não falou

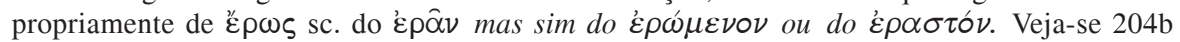

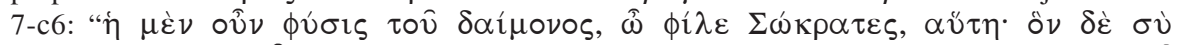

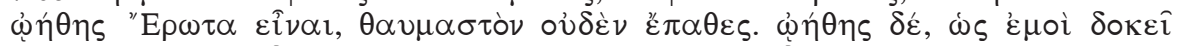

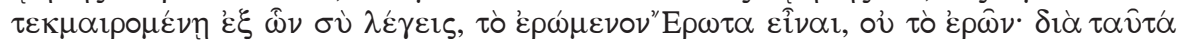

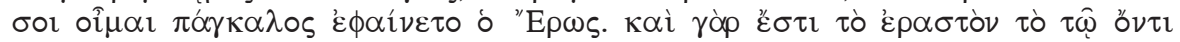

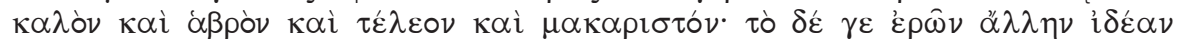

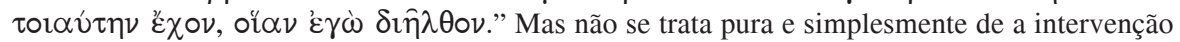
de Agatão ter deixado fora de consideração uma parte (e, segundo a perspectiva perfilhada por Sócrates, a parte fundamental) dos significados de uma palavra. Trata-se de algo com muito maior alcance. Pois o que está em causa é Agatão ter pressuposto acriticamente o modelo tradicional de "हैбpoऽ", para usar a palavra do Cratylus (cf. supra, nota 5), ou seja, o modelo da invasão por uma potência exterior. Ao pressupor assim, acriticamente, esse modelo, Agatão esquece tudo quanto diz respeito à própria constituição do desejo enquanto tal. Assim, o "pecado" de Agatão é não ter curado de averiguar o complexo de fenómenos e formas de realidade sem o qual o encanto nada significaria e o poder de "ع้ $\sigma \rho \varsigma$ ", bem vistas as coisas, nada poderia sobre ninguém. 
Isto por um lado. Por outro lado, o que caracteriza o $\mu \varepsilon \tau \alpha \xi \hat{v} \kappa \alpha \lambda \circ \hat{v} \kappa \alpha i$ $\alpha^{\prime} \imath$ $\chi \rho \circ \hat{v}$, a instância intermédia entre o Belo e o seu oposto, é precisamente o facto de poder comportar já, na sua própria constituição, ainda antes da presença de

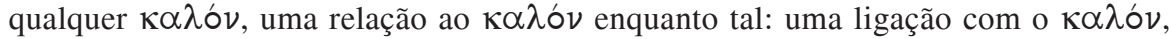
formada a partir do próprio $\mu \varepsilon \tau \alpha \xi \hat{v}$, sustentada apenas por esta base, e que na verdade é a condição para se poder ser afectado ou impressionado pela presença do $\kappa \alpha \lambda o^{\prime} v$ e sujeito ao seu domínio ou à conquista por ele.

Para perceber bem isto, convém ter nítida e aguda consciência do que significa

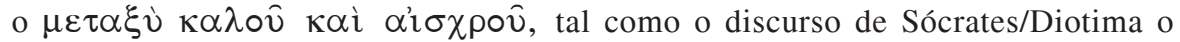

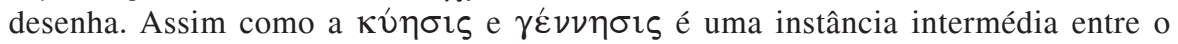
mortal e o imortal que não equivale a nenhuma espécie de mosaico dos opostos em causa, antes constitui, em todos e cada um dos seus momentos, um modo-de-ser original e próprio, que não comporta em si nada, absolutamente nada dos opostos em estado puro, antes põe em si mesmo e a partir de si mesmo uma relação com os dois opostos, de tal modo que um deles, o $\theta v \eta \tau o ́ v$, é aquilo de que foge e o outro,

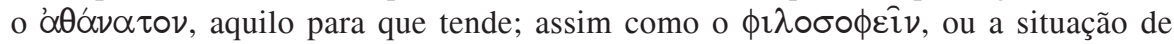
acesso que lhe é própria, é uma instância intermédia entre o saber e o ignorar, que não equivale a nenhuma espécie de mosaico de momentos de puro saber e de puro não--saber, antes constitui uma forma original e própria de cruzamento (um cruzamento em tudo cruzamento: em tudo atravessado entre o saber e o não-saber), que não comporta em si nada, absolutamente nada, dos opostos em estado puro, antes põe em si mesmo e a partir de si mesmo (quer dizer, a partir do cruzamento) uma relação com os dois opostos, de tal modo que um deles (a ignorância) é aquilo de que foge e o outro (o saber) aquilo para que tende - assim também a instância intermédia entre o Belo e o seu oposto não equivale a nenhuma espécie de mosaico de momentos de beleza e de momentos do oposto, antes constitui uma forma original e própria de cruzamento entre o belo e o seu oposto (um cruzamento em tudo cruzamento

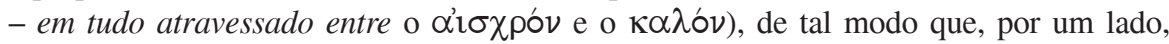
este cruzamento não comporta em si nada, absolutamente nada dos opostos em estado puro, antes constitui em si mesmo uma relação com cada um deles - e, por outro lado, o cruzamento em causa está dominado por uma tendência e tensão para longe de um em direcção ao outro. Ora, é este modo-de-ser constitutivamente e em tudo atravessado

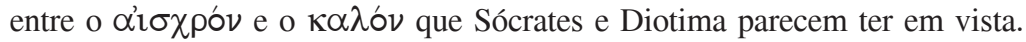

Mas, sendo assim, que é que em concreto corresponde a isto?

Para responder a esta pergunta, é preciso atentar bem na peculiaridade do retrato do humano que está traçado no discurso de Sócrates/Diotima. Esse retrato insiste no papel do $\mu \varepsilon \tau \alpha \xi \hat{v}$, como matriz da realidade humana. Isso quer dizer, como vimos, que o humano é uma realidade inteiramente constituída no modo do desejo, da tensão do desejo. Mas, por outro lado, vendo bem, o significado disto é muito diferente daquele que pode desenhar-se num acompanhamento distraído deste mesmo enunciado. Pois, segundo Sócrates/Diotima, sermos $\mu \varepsilon \tau \alpha \xi v ́$ significa que somos no cruzamento de $\pi \varepsilon \nu i ́ \alpha$ e $\pi \delta$ óos. Sermos $\mu \varepsilon \tau \alpha \xi \dot{v}$ significa, portanto, que a forma da nossa realidade é o oxímoro - i.e. não apenas um ter contacto com algo de oximórico (testemunhá-lo), etc., mas, para além disso, ser na forma de oxímoro: ser 
um oxímoro $^{89}$. De tal modo que essa é que é, se assim se pode dizer, a nossa "substância" e a não-coincidência, o desencontro, a tensão e dilaceração do oxímoro perpassa tudo aquilo que nós somos.

Por outras palavras, o $\mu \varepsilon \tau \alpha \xi u ́$ descrito por Sócrates/Diotima é uma realidade precária, marcada por míngua ou restrição, mas votada a mais do que si mesma quer dizer, com a precisão de mais inscrita em si, na própria míngua ou restrição de que está presa. O $\mu \varepsilon \tau \alpha \xi u ́$ é o escasso com missão de mais, em demanda de mais, na impossibilidade de ser simplesmente apenas o que é. Ou melhor: o $\mu \varepsilon \tau \alpha \xi \hat{v}$ descrito por Sócrates/Diotima não é apenas o escasso com missão de mais, é o escasso com missão de $\pi$ ópos, de total supressão da escassez, de aquisição do pleno. Mas isto, por sua vez, também não é tudo. Sócrates e Diotima insistem na multiplicidade de componentes do $\mu \varepsilon \tau \alpha \xi v$ ou do oxímoro que assim nos forma: várias momentos $\mu \varepsilon \tau \alpha \xi \hat{v}$, de efeito convergente, mas não idênticos e, de facto, irredutíveis uns aos outros. Portanto, não se trata apenas de uma peculiar realidade em oxímoro e em demanda, mas sim de um feixe ou cruzamento de restrições, de formas de escassez ou míngua e de correspondentes "missões de mais", ou melhor: de "missões de $\pi o ́ p o \zeta "$ (de total supressão da escassez, de aquisição do pleno). É isso que nos define, segundo Sócrates/Diotima: um feixe ou cruzamento de oxímoros de $\pi \varepsilon \nu i \alpha / \pi \delta$ ós e, nesse sentido, de "a-caminhos", de "demandas" - uma realidade multiplamente escassa, precária, e ao mesmo tempo em múlitplas tensões para mais do que si mesma, ou melhor, em múltiplas missões de $\pi$ ópos.

Assim, o humano não se limita a ser, enquanto vida, uma tensão ou um projecto de imortalidade (ou, mais precisamente, um projecto de imortalidade intrinsecamente retido ou embargado por mortalidade, sempre a caminho de uma imortalidade que lhe falta). Ao mesmo tempo que é isso, é também uma tensão e projecto de saber (ou, mais precisamente, um projecto de saber intrinsecamente retido ou embargado por não-saber, sempre a caminho de um saber que na verdade falta). Mas também isso ainda não é tudo. Pois, como aqui importa pôr especialmente em destaque, Sócrates e Diotima insistem igualmente no facto de o humano ser sempre também uma tensão ou um projecto de $\kappa \alpha \lambda \delta$ o (ou, mais precisamente, um projecto de $\kappa \alpha \lambda o ́ v$ retido ou embargado ainda pela sua ausência). Estar na condição humana é, de raiz, estar a caminho e em demanda de um $\kappa \alpha \lambda$ ó $\nu$ em falta. De sorte que, em virtude da forma como nos achamos constituídos, somos e não podemos deixar de ser também missão do belo que a forma como estamos constituídos reclama mas não assegura, antes deixa ainda fora de alcance. E também nesse aspecto somos um

${ }^{89}$ Não cabe aqui sequer esboçar uma análise dos antecedentes e significado da figura do oxímoro no pensamento grego antigo - e, em especial, do repetido recurso ao oxímoro para exprimir a condição humana ou vários aspectos dela. Assinale-se apenas, muito de fugida, que de facto se encontra desenhada no pensamento grego qualquer coisa como uma "antropologia do oxímoro" (quer dizer, uma antropologia que nos reconhece como oxímoro) e que a história e a interpretação dessa "antropologia do oxímoro" (que já se desenha antes de Platão e constitui um dos mais importantes antecedentes da perspectiva aberta no discurso de Sócrates/Diotima) estão, no fundamental, ainda por fazer. 
oxímoro, com tudo o que isso significa de tensão, de desencontro interno e de inquietação - mas, ao mesmo tempo também (porque se retrata de um oxímoro em cuja composição entra nada menos do que $\pi$ ópos) com tudo o que isso implica de iniciativas, desenvolvimentos e "viagens" à procura de uma resolução do oxímoro: à procura de algo que permita ultrapassar o desencontrado que nós mesmos somos

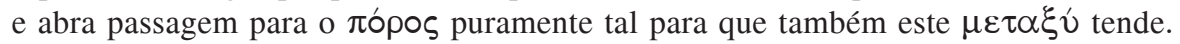

Consideremos um pouco mais em pormenor alguns aspectos do que isso significa.

Em primeiro lugar, significa que a relação com o Belo não se constitui apenas a partir de algo que vem ao nosso encontro - e o Belo não é só (mesmo que seja também) algo com que se topa. Não. Há uma relação com o Belo inscrita no nosso próprio modo-de-ser. Como se disse, o que caracteriza cada um de nós não é apenas uma tensão para a preservação de si, da própria identidade (constituída de tal modo que, por outro lado, envolve também uma componente de tensão para o saber). Para além disso, caracteriza-nos ainda uma tensão para o $\kappa \alpha \lambda \delta$, para o encontro e posse dele - uma tensão de cada um para si-mesmo-na-posse-do- $\kappa \alpha \lambda o ́ \nu .{ }^{90}$ Por outras

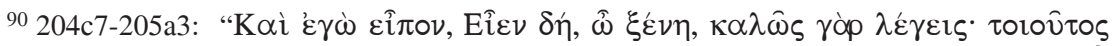

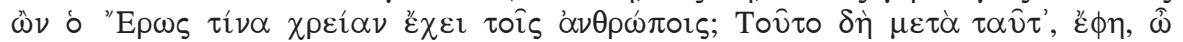

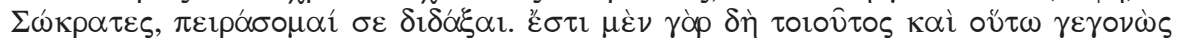

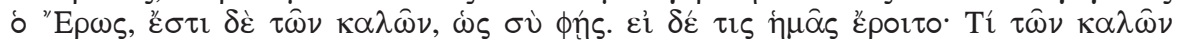

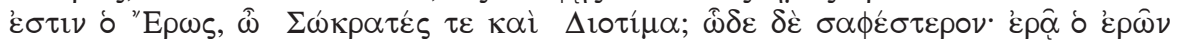

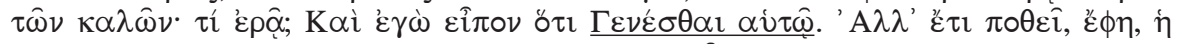

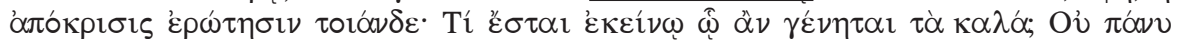

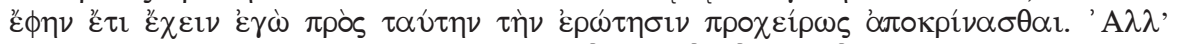

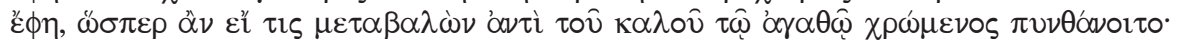

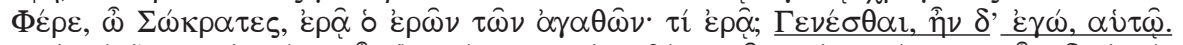

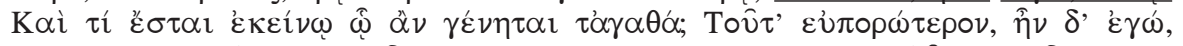

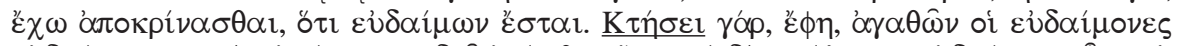

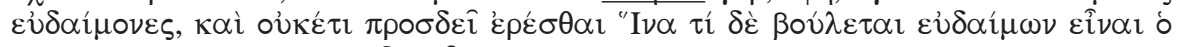

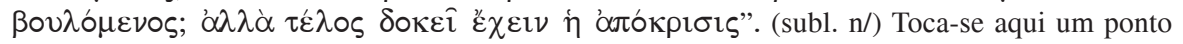
que é absolutamente decisivo e não podemos deixar de pôr em destaque como tal. A tensão do

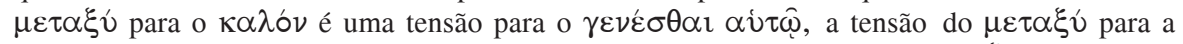

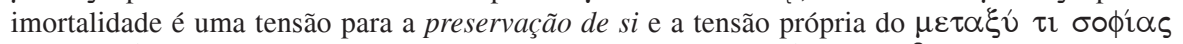

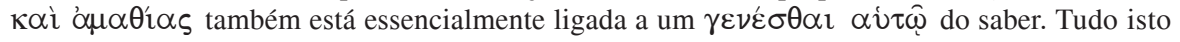
significa que o complexo de fenómenos posto em evidência por Sócrates/Diotima tem um nexo fundamental com a ipseidade (com um si mesmo - $\alpha \hat{\tau} \tau \delta$ s - constituído de tal modo que implica relação consigo, não-indiferença a si, etc.) - nexo que o discurso, na verdade, mesmo que também não chegue a entrar na averiguação dele, sempre de novo faz notar. Por outras palavras, o $\mu \varepsilon \tau \alpha \xi u ́$ descrito por Sócrates/Diotima requer qualquer coisa como um si mesmo em relação consigo (e, de facto, numa tal relação consigo que seja não-indiferente a si, dedicado a si-faça caso de si, etc.). Se assim se pode dizer, o $\mu \varepsilon \tau \alpha \xi u ́$ é essencialmente na primeira pessoa. De sorte que, no cruzamento de $\pi \varepsilon v i ́ \alpha$ e $\pi \delta$ ó

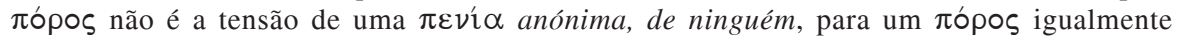
anónimo, de ninguém, mas sim a tensão de um si-mesmo na $\pi \varepsilon v i ́ \alpha$ para um si-mesmo em $\pi$ tópos. 
palavras: a tensão constitutiva do Humano não requer só a continuação de si - mas, além disso, também um si mesmo melhorado pelo advento e pelo alcance do $\kappa \alpha \lambda o ́ v$, quer dizer, por um $\kappa \alpha \lambda$ óv tornado seu e que, assim, transforme e transfigure o acontecimento do próprio. Ou seja, independentemente de vir ou não vir, de se dar ou não se dar a encontro algo de Belo, há sempre já no modo-de-ser próprio do

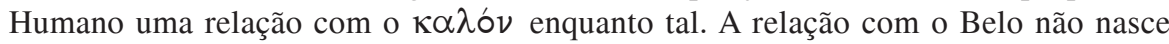
do encontro com ele, antes é aquela em que se vem inscrever qualquer $\kappa \alpha \lambda \delta$ v que se dê a encontro. Em suma, a relação com o Belo já está constituída in absentia a natureza humana está já dirigida ao Belo na ausência dele, e isto na forma de qualquer coisa como uma vocação para o Belo, um projecto do Belo a haver ou a encontrar (quer dizer, como se disse, um projecto de si mesmo na posse do Belo) de tal modo que a relação consigo mesmo é também (e é centralmente) uma relação com essa vocação ${ }^{91}$.

A relação original com o Belo constitui-se, portanto, na ausência dele. Mas isto de tal modo que, como Sócrates e Diotima sublinham, a ausência aí em causa não é em nada equivalente a um puro e simples não-estar, que se esgote nisso (e que, por isso mesmo, desconheça também o fazer falta). Tampouco acontece que essa ausência equivalha à pura e simples presença do oposto. Numa palavra, a ausência em causa não é de pura $\pi \varepsilon v i ́ \alpha$ em relação ao $\kappa \alpha \lambda \delta$. Não, a ausência de $\kappa \alpha \lambda \delta$ v que, segundo Sócrates/Diotima, inere à natureza humana é uma ausência de tipo $\mu \varepsilon \tau \alpha \xi \hat{v}$ - diminuída, contrariada, transformada pelo que também tem de $\pi$ ópos, ou seja, diminuída, contrariada, transformada por um elemento de presença $e$ alcance do Belo - a presença na forma do mero projecto, a presença na modalidade negativa do fazer falta, a presença-no-modo-da-ausência-sentida-como-tal, quer dizer, já voltada para aquilo que ainda se mantém fora de alcance.

Por outras palavras, segundo Sócrates/Diotima, o que marca de raiz a constituição do ser humano e cria a relação original com o Belo é uma peculiar forma de "vazio" - não um "vazio" qualquer, indeterminado, mas um vazio que o é já

91 O Belo é, assim, um constituinte do humano enquanto terminus ad quem, alvo ou demandado do $\mu \varepsilon \tau \alpha \xi u ́$ que nos conforma. Se assim se pode dizer, é o próprio " $\varepsilon\llcorner\sigma \rho \varsigma$ " do

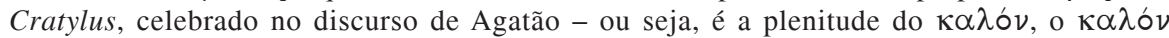
superlativo (isso que se caracteriza justamente por ter de vir de fora, como algo acrescentado, superveniente àquilo que nós somos, quer dizer, como algo complementar em relação ao acontecimento de falta que nós somos) - que já está como que antecipado na forma da petição ou da demanda (no facto de nós sermos petição, demanda). De sorte que esse "exterior" e "ausente" (que ainda tem de ser encontrado ou tem de vir) é - enquanto demandado - um elemento da nossa própria realidade: algo de "interno" ao nosso próprio ser. Neste sentido, o discurso de Sócrates/Diotima retoma, a seu modo, um elemento fundamental do discurso de Aristófanes: a ideia de que o enamoramento ou a paixão, ou como se lhe queira chamar, é algo que "rebenta" num determinado momento e em vista de um determinado ente, sim, mas de tal modo que isso que assim "rebenta" é apenas o desenvolvimento de um enamoramento, uma paixão (ou como se lhe queira chamar) sempre já inscrito e sempre já de algum modo a "levedar" na própria forma como estamos constituídos. Sobre este aspecto, veja-se M. J. de CARVALHO, Die Aristophanesrede in Platons Symposium, op. cit., §§ 14, 16, 17, 18. 
definidamente do $\kappa \alpha \lambda o ́ \nu$, como um "negativo" ainda por preencher ou converter mas que, de todo o modo, põe já em inanulável e irreversível contacto com aquilo para que remete. Assim, parafraseando as fórmulas de Diotima a respeito da instância intermédia entre o imortal e o mortal, podemos descrever a relação original com o

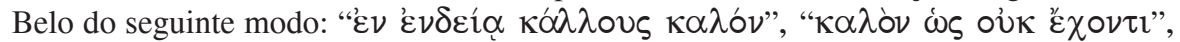

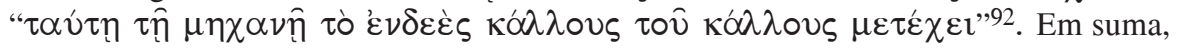
segundo Sócrates/Diotima, a relação original com o Belo, que está inscrita na própria constituição do ser humano, tem o carácter de uma petição ou demanda, em correspondência àquilo que designa o conceito de $\mu \varepsilon \tau \alpha \xi \hat{v}$ : ser-já-em-ligação-com-o-que-falta (aquém dele mas a caminho dele, na precisão, no projecto e na procura do que falta). De sorte que, segundo Diotima, o que define a condição humana é também estar nisto ("prisioneira" disto): atravessada a caminho do Belo, já sem recuo para uma posição fora (quer dizer: aquém) desse a-caminho, dessa petição, desse almejar, mas, por outro lado, também sempre ainda aquém do terminus ad quem dessa petição ou demanda - sempre ainda retida, ainda a-caminho, na travessia dessa petição.

Isso traduz-se, em primeiro lugar, numa consequência óbvia (algo que nunca poderia ocorrer, se a relação com o Belo se constituísse apenas mediante a sua presença), e que é a seguinte: a realidade humana deixada na total ausência do que

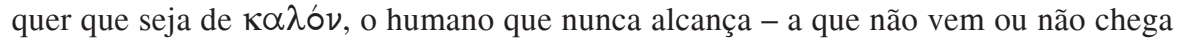
- nada de belo, converte-se por isso mesmo (e já só por isso) em lugar de desolação.

Mas essa não é a única consequência. Há ainda outras - designadamente para aquilo que acontece quando efectivamente vem a encontro algo de belo. Assim, a presença do Belo, quando nos cruzamos com ele, não é pura e simplesmente tal, nem tem apenas a determinação disso mesmo que se encontra, com os seus predicados, a sua intensidade própria, etc. Trata-se de uma presença que preenche e responde uma presença que se vem inscrever no quadro da petição ou demanda já constituída independentemente dela, quer dizer, do $\mu \varepsilon \tau \alpha \xi \hat{v}$. E isto de tal modo que, no fundo, o Belo que efectivamente se alcança é sempre chamado justamente a satisfazer a petição, ou seja, nem mais nem menos do que a resolver o $\mu \varepsilon \tau \alpha \xi \dot{v}$ no seu termo positivo (a ultrapassá-lo, a convertê-lo em puro $\pi$ ó $\rho \circ)^{93}$. De sorte que, vendo bem, a determinação com que se apresenta o $\kappa \alpha \lambda$ óv vindo a encontro na verdade nunca é só a sua - reflecte justamente também a demanda ou petição que o ser humano tem inscrita em si, ou, mais precisamente, reflecte as relações (de correspondência ou não correspondência, de preenchimento ou não-preenchimento) que há entre aquilo que efectivamente se oferece - o Belo posto ao alcance - e a petição ou demanda a que, pelas razões referidas, sempre é chamado a responder.

92 O "belo na falta de beleza", o "belo como para aquilo que o não tem", "por via deste expediente aquilo que tem falta de beleza participa do belo".

93 É isso que, como vimos, está em causa na estrutura do $\mu \varepsilon \tau \alpha \xi u ́$ enquanto tal - e é

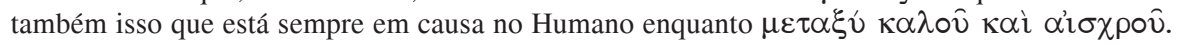


Daí resulta, finalmente, uma possibilidade decisiva, absolutamente nos antípodas do discurso de Agatão e que importa não esquecer: pode justamente acontecer que a própria presença do belo, enquanto tal, esteja marcada e minada por ausência, porque o belo a que a natureza humana (o $\mu \varepsilon \tau \alpha \xi v$ inscrito em nós) constitutivamente se reporta é mais ou é outro ou fica de todo o modo para lá daquele que, de facto, se oferece. Isso significa que, quando se fala de uma relação com o belo constituída in absentia (e que, mantendo-se o $\mu \varepsilon \tau \alpha \xi u ́$, mantém a ausência), a ausência aí em causa não corresponde forçosamente a uma situação absolutamente desprovida do que quer que seja de Belo efectivamente tido ou já alcançado (de tal modo que só se tenha e possa ter o Belo na forma de um projecto do que falta). Não. Haver ausência não significa aqui forçosamente total falta de alcance, mas sim que, mesmo que se esteja já na posse de algo Belo (e acontecendo até que o Belo já descoberto e posto ao alcance não seja de pouca monta, nem em amplitude nem em intensidade),

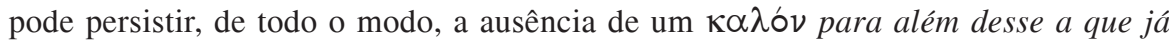

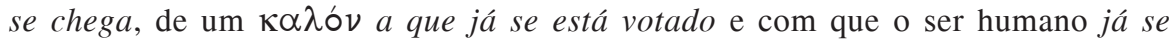
relaciona como algo que ainda lhe escapa - algo ainda-não ${ }^{94}$. De tal modo que a posse desse $\kappa \alpha \lambda \delta$ a que já se chega, pese embora tudo o que tem de alcance e pleno

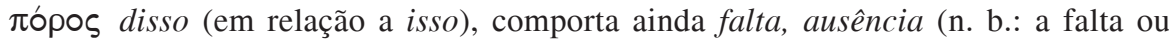
ausência $\mu \varepsilon \tau \alpha \xi \hat{v})$ de um outro $\kappa \alpha \lambda \delta$ v ainda por alcançar e sem cuja posse a situação em que se está ainda continua marcada por ausência e fica aquém (e, de facto, até mesmo muito aquém) do puro $\pi$ ópos para que o $\mu \varepsilon \tau \alpha \xi \hat{v}$ que nós mesmos somos constitutivamente tende. Por outras palavras, em relação à esfera do $\kappa \alpha \lambda$ óv, a ausência pode perfeitamente ter que ver "apenas" com a condição sobredimensionada da própria petição ou demanda inscrita na constituição do humano, que nos põe, enquanto portadores dessa petição ou demanda, por assim dizer, para lá de cada

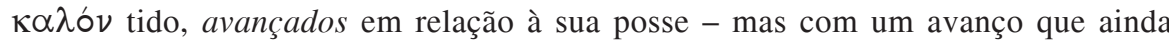
tem a forma de $\pi \varepsilon v i ́ \alpha$ x $\pi \delta$ óps: é ainda só o do projecto e da falta de algo mais.

Não podemos seguir para diante os complexos desenvolvimentos que o discurso de Sócrates/Diotima produz a partir deste núcleo que aqui procurámos fixar nos seus traços fundamentais ${ }^{95}$. Mas há dois aspectos que não podemos deixar de sublinhar, mesmo que em anotações muito breves.

${ }^{94} \mathrm{E}$ isto não somente daquele modo que Sócrates sublinha no diálogo preliminar com Agatão (200d) - ou seja, porque a demanda do $\kappa \alpha \lambda o ́ v$ não é a demanda da sua posse apenas num instante e a posse do $\kappa \alpha \lambda \zeta v$ num dado momento já se relaciona com o ainda-não $d a$

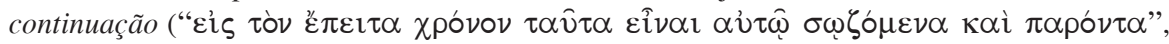
como se diz em 200d9-10) - mas também porque o $\kappa \alpha \lambda \delta$ v que já está ao alcance pode não coincidir com aquele para que tende o $\mu \varepsilon \tau \alpha \xi u ́$, quer quantitativamente (no que diz respeito à sua intensidade), quer qualitativamente.

95 Consideramos aqui apenas a base ou o núcleo em que radica todo o resto da doutrina apresentada por Diotima. Ficam de fora todos os desenvolvimentos ulteriores. De resto, vendo bem, esses desenvolvimentos já não concernem apenas o próprio $\mu \varepsilon \tau \alpha \xi \grave{v} \kappa \alpha \lambda \circ \hat{v} \kappa \alpha i$

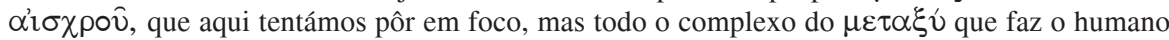

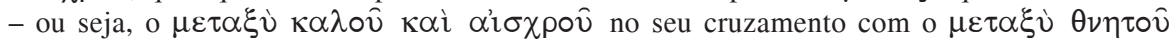

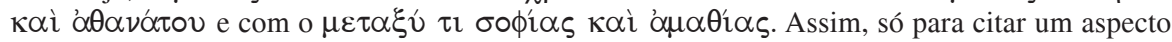


O primeiro diz respeito ao carácter puramente formal do Belo que o discurso de Sócrates/Diotima assim reconhece como constituinte do Humano. Pode falar-se de um carácter formal, antes do mais, por uma particularidade da língua grega, facilmente susceptível de passar despercebida e que é importante para se perceber

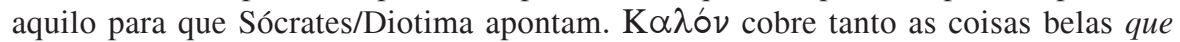
há (e, nesse sentido, o belo que se encontra) quanto aquelas que é belo fazer - as acções enquanto tais, o belo que reside no facto de um ser humano conseguir agir

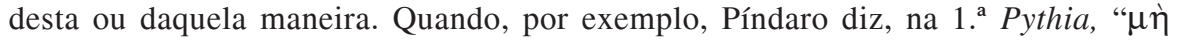

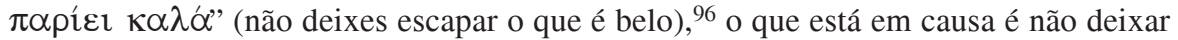
escapar tanto aquelas coisas que se colhem sob a forma de serem encontradas e de preencherem a nossa vida com a sua presença (o contacto que com elas temos, etc.), quanto aquelas outras que só têm lugar se postas por isso mesmo que fazemos, quer dizer, pelo facto de o fazermos - se assim se pode dizer, os nossos feitos $^{97}$. Isto

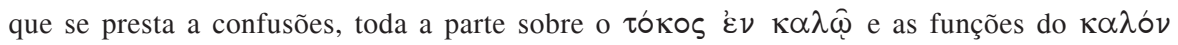
nesse contexto (206) tem que ver já com os diversos sentidos que pode ter o $\kappa \alpha \lambda o ́ v$, com uma mais demorada análise do cruzamento dos diferentes momentos de $\mu \varepsilon \tau \alpha \xi \hat{v}$, da relação que há entre eles, de diversos fenómenos que resultam desse cruzamento e também tem que ver com os diferentes desenvolvimentos que um $\mu \varepsilon \tau \alpha \xi \dot{v}$ constituído nesse cruzamento, como o é um ser humano, pode experimentar na tentativa de resolver a tensão e a demanda que tem implicadas no seu próprio modo-de-ser. Assinale-se, finalmente, que também a breve análise

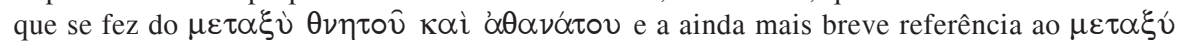
$\tau_{\imath} \sigma o \phi i ́ \varsigma_{\varsigma} \kappa \alpha i ̀ j \mu \alpha \theta i \alpha \varsigma$ se limitaram àquilo que é estritamente indispensável para fixar a própria peculiaridade do conceito de $\mu \varepsilon \tau \alpha \xi \hat{v}$ e, a partir daí, ganhar a pista do que está em

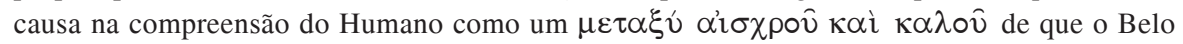
faz parte como pólo positivo da tensão que o perpassa.

${ }^{96}$ Pythia I, 86.

97 De facto, esta caracterização ainda envolve uma considerável componente de simplificação. Pois, além do que vimos sobre o belo tido e do belo feito, há toda uma multiplicidade de aspectos e diferenças que teriam de ser tidos em conta: a) aquilo que aparece caracterizado como tendo uma conotação mais "estética" (se se pode usar aqui tal determinação) e aquilo que tem uma conotação mais ligada à ideia de qualidade, de

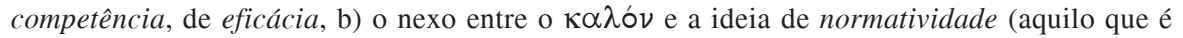
de recomendar, de exigir, etc.), c) a ideia de excepção (aquilo que é difícil ou remoto, que mais ninguém alguma vez conseguiu alcançar, etc.) e ainda d) o facto de a relação com o $\kappa \alpha \lambda o ́ v$, em qualquer dos sentidos a que se aludiu, não ser uma relação a sós com isso, mas também uma relação com a forma como isso é presenciado ou testemunhado pelo olhar alheio, que vê o que se passa connosco (e isto de tal modo que há uma componente de $\phi i \lambda o \tau \imath \mu i ́ \alpha$, em virtude da qual não é indiferente a forma como a vida própria é testemunhada pelo olhar

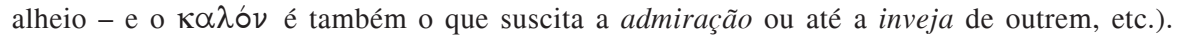
Estes aspectos qualificam, mas não modificam o essencial daquilo que aqui está em causa. Sobre a forma como o $\kappa \alpha \lambda \delta$, para que se tende, envolve, ao mesmo tempo, aspectos "estéticos" e "práticos" (as coisas que nos vêm e os próprios feitos), veja-se, por exemplo, R. G. BURY (ed.), The Philebus of Plato, Cambridge, University Press, 1897, reed.: Salem (N. Hampsh.), Ayer, 1988, 176s., M. HOFFMANN, Die ethische Terminologie bei Homer, Hesiod und den alten Elegikern und Jambographen, I Homer, Tübingen, Laupp, 1914, 48, J. JÜTHNER, 
Kalokagathia, in: Charisteria. Alois Rzach zum 80. Geburtstag dargebracht, Reichenberg, Stiepel, 1930, 99-119, J. BERLAGE, De vi et usu nominum KA $\Lambda \mathrm{O} \Sigma \mathrm{KA \Gamma A \Theta O \Sigma ,}$

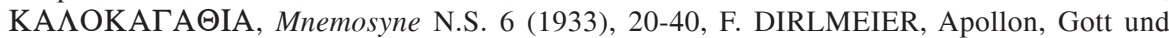
Erzieher des hellenischen Adels, Archiv für Religionswissenschaft 36 (1939), 277-299, 284ss. (=IDEM, Ausgewählte Schriften zu Dichtung und Philosophie der Griechen, ed. Herwig Görgemanns, Heidelberg, Winter, 1970, 31-47, 36ss.), F. HEINIMANN, Nomos und Physis,

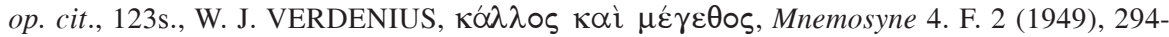
298, E. SCHWARTZ, Ethik der Griechen, Stuttgart, Koehler, 1951, 19ss., G. MEIWES, Die $\kappa \alpha \lambda \sigma_{\zeta}$-Vorstellung bei Homer Diss., Hamburg, 1952, A. GOMME, The Interpretation of

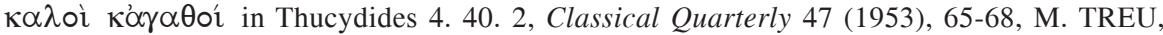
Von Homer zur Lyrik. Wandlungen des griechischen Weltbildes im Spiegel der Sprache, München, Beck, 1955, 35ss., H.-J. CLASSEN, Sprachliche Deutung als Triebkraft platonischen und sokratischen Philosophierens, München, Beck, 1959, 138ss., 145ss., E. R. DODDS (ed.), Plato Gorgias, Oxford, Clarendon Press, 1959, ad 474d4, A. W. H. ADKINS, Merit and Responsibility. A Study in Greek Values, Oxford, Clarendon Press, 1960, passim, esp. 186ss., H. WANKEL, Kalos kai agathos, Diss. Würzburg, 1961, reed.: O. KUNSEMÜLLER, Die Herkunft der platonischen Kardinaltugenden/H. WANKEL, Kalos kai agathos, N.Y., Arno Press, 1979, H. FRÄNKEL, Dichtung und Philosophie des frühen Griechentums. Eine Geschichte der griechischen Epik, Lyrik und Prosa bis zur Mitte des fünften Jahrhunderts, München, Beck, 1962, 1976, 211s., 457, 525, 554ss., K. M. DAWSON, Spoudaiogeloion. Random Thoughts on Occasional Poems, Yale Classical Studies 19 (1966), 37-76, em especial 50-58, A. W. H. ADKINS, Basic Greek Values in Euripides' Hecuba and Hercules furens, Classical Quarterly 16 (1966), 193-219, P. HUART, Le vocabulaire de l'analyse psychologique dans l'oeuvre de Thucydide, Paris, Klincksieck, 1968, 454s., A. W. ADKINS, From the Many to the One. A Study of Personality and Views of Human Nature in the Context of Ancient Greek Society, Values and Beliefs, Ithaca (NY), Cornell University Press, 1970, 131s., 145, 200, K. J. DOVER, Greek Popular Morality in the Time of Plato and Aristotle, Berkeley/LA, University of California Press, 1974, 41ss., 69s., F. SOLMSEN, Intellectual Experiments of the Greek Enlightenment, Princeton (NJ), Princeton University Press, 1976, 152ss., T. IRWIN, Plato's Moral Theory. The Early and Middle Dialogues, Oxford, Clarendon Press, 1977, 170ss., 234s., E. MÉRON, Les idées morales des interlocuteurs de Socrate dans les dialogues platoniciens de la jeunesse, Paris, Vrin, 1979, 17ss., 21 ss., P. WOODRUFF (ed.), Hippias Major, Oxford, Basil Blackwell, 1982, XIIs., 109ss., J. TRIANTAPHYLLOPOULOS, Das Rechtsdenken der Griechen, München, Beck, 1985, 91ss., J.-P. VERNANT, L'individu, la mort, l'amour. Soi-même et l'autre en Grèce ancienne, Paris, Gallimard, 1989, 64ss., P. STEMMER, Platons Dialektik. Die frühen und mittleren Dialoge, Berlin, de Gruyter, 1992, 24, S. J. RIDDERBOS, Plato, Phaedo 94a12-b3, Mnemosyne 47 (1994), 224, F. BOURRIOT, Kalos kagathos - kalokagathia: d'un terme de propagande de sophistes à une notion sociale et philosophique: étude d'histoire athénienne, Hildesheim, Olms,

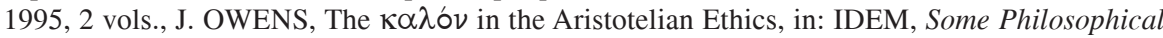
Issues in Moral Matters. The Collected Ethical Writings of Joseph Owens, Roma, Ed. Accademia Alphonsianae, 1996, 27-44, E. PETTERSSON, The Kalon and the Agathon in Plato's Socratic Dialogues, Diss. University of California Irvine, 1996, B. HUSS, Xenophons Symposion. Ein Kommentar, Stuttgart/Leipzig, Teubner, 1999, em especial 62ss., F. ROSCALLA, «Kalokagathia» e «kaloi kagathoi» in Senofonte, in: C. J. TUPLIN (ed.), Xenophon and His World: Papers From a Conference Held in Liverpool in July 1999, Stuttgart, Steiner, 2004, 115-124, G. R. LEAR, Happy Lives and the Highest Good. An Essay on Aristotle's Nichomachean Ethics, Princeton/ Oxford, Princeton University Press, 2004, 123ss. D. HYLAND, Plato and the Question of Beauty, Bloomington (Ind.), Indiana University Press, 2008, 4s. 
significa que a palavra $\kappa \alpha \lambda o ́ v$ tem um sentido mais extenso do que aquele que nós tendemos a atribuir-lhe, uma determinação indiferenciada, genérica (não específica) que a) cobre todas as formas de preenchimento, determinação ou qualificação do curso da vida (i.e. tudo aquilo que define o que é de nós ou se faz de nós) e b) em relação a todas essas formas de qualificação ou preenchimento do curso da vida, aponta para algo de elevado e perfeito - que torna pleno, acerta em cheio, é extraordinário ${ }^{98}$. Ora, o que está aqui em jogo não é apenas uma particularidade

98 A amplitude genérica ou formal do conceito de $\kappa \alpha \lambda \delta \nu$ manifesta-se de forma

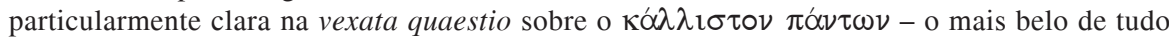
quanto pode ser alcançado na vida. Um dos aspectos repetidamente focados nos textos onde a questão aparece glosada é justamente a diversidade das perspectivas que os diferentes seres

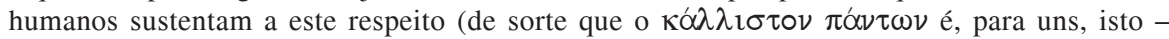
para outros, aquilo), etc. Ora, por um lado, se há variedade das teses sustentadas, essa

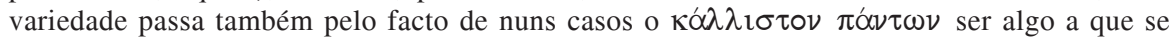
acede na forma de isso vir, ao passo que noutros casos é algo a que se acede na forma de se conseguir fazê-lo. A própria existência desta "querela" põe, de resto, em evidência a instância

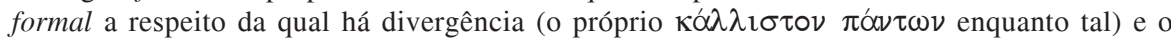
modo como as diferentes teses sustentadas correspondem justamente a identificações ou desformalizações dessa instância formal, que todas pretendem captar adequadamente e que é aquilo que, independentemente do conteúdo concreto que se lhe atribui, todos procuramos.

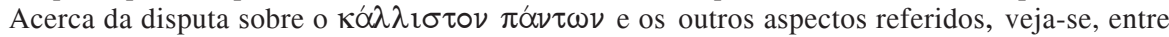
outros: J. BURCKHARDT, Griechische Kulturgeschichte, Berlin/Stuttgart, Spemann, 18981902, reed. Darmstadt, Wissenschaftliche Buchgesellschaft, 1977, vol. II, 342ss., K. OHLERT, Rätsel und Rätselspiele der alten Griechen, Berlin, Mayer \& Müller, 1912, 119ss., A. C. PEARSON (ed.), The Fragments of Sophocles, vol. II, Cambridge, University Press, 1917, ad 356, N. TERZAGHI, La scelta della vita, Studi italiani di filologia classica N.S. 1 (1920), 364-400, F. DORNSEIFF, Pindars Stil, Berlin, Weidmann, 1921, 97ss., R. HERZOG, Das delphische Orakel als ethischer Preisrichter, in: E. HORNEFFER, Der junge Platon, I, Sokrates und die Apologie, Giessen, Töpelmann, 1922, 149-170, F. WEHRLI, $\Lambda A \Theta E B I \Omega \Sigma A \Sigma$, Studien zur ältesten Ethik bei den Griechen, Leipzig/ Berlin,Teubner, 1931, 30ss., W. KROEHLING, Die Priamel (Beispielreihung) als Stilmittel in der griechischrömischen Dichtung nebst einem Nachwort: Die altorientalische Priamel, Greifswald, Dallmeyer, 1935, W. A. van OTTERLO, Beitrag zur Kenntnis der griechischen Priamel, Mnemosyne 8 (1940), 145-176, E. FRÄNKEL (ed.), Aeschylus Agamemnon. vol. II. Oxford, Clarendon Press, 1950, reed. 1974, ad 899-902, R. JOLY, Le thème philosophique des genres de vie dans l'antiquité classique, Académie Royale de Belgique, Mémoires, Classe des Lettres et des Sciences Morales et Politiques LI, 3 (1956), em especial 12ss., K. HESS, Der Agon zwischen Homer und Hesiod, Winterthur, Keller, 1960, 10ss., W. BURKERT, Weisheit und Wissenschaft. Studien zu Pythagoras, Philolaos und Platon, Nürnberg, Carl, 1962, 150ss., B. SNELL, Die alten Griechen und wir, Göttingen, Vandenhoeck \& Ruprecht, 1962, 50s., E. L. BUNDY, Studia Pindarica, Berkeley, University of California Press, 1962, 4ss., H. FRÄNKEL, Dichtung und Philosophie des frühen Griechentums. Eine Geschichte der griechischen Epik, Lyrik und Prosa bis zur Mitte des fünften Jahrhunderts, München, Beck, 1962, 1976, 211, U. SCHMID, Die Priamel der Werte im Griechischen. Von Homer bis Paulus, Wiesbaden, Harrassowitz, 1964, F. WEHRLI, Hauptrichtungen des griechischen Denkens, Zürich/Stuttgart, Artemis, 1964, 44ss., B. SNELL, Dichtung und Gesellschaft. Studien zum Einfluß der Dichter auf das soziale Denken und Verhalten im alten Griechenland, Hamburg, Claassen, 1965, 103s., C. W. MÜLLER, Gleiches zu Gleichem. Ein Prinzip frügriechischen Denkens, Wiesbaden, Harrassowitz, 1965, 152s., R. VISCHER, Das einfache Leben. Wort- und 
da língua grega, relevante para se perceber o sentido do texto de Platão, mas sem outro alcance. Não: o que está aqui em jogo é uma componente do próprio fenómeno em causa, no sentido em que a petição inscrita no $\mu \varepsilon \tau \alpha \xi \hat{v}$ constituinte do humano, enquanto esse $\mu \varepsilon \tau \alpha \xi \hat{v}$ está dirigido ao belo, é, de facto, uma petição de global "embelezamento" da própria vida, em todos e cada um dos seus aspectos, por todas as vias, de todas as formas que couber - da maneira mais abrangente e plena que for possível ${ }^{99}$.

Mas isto ainda não é tudo. O Belo a que está dirigido o $\mu \varepsilon \tau \alpha \xi u ́$ constituinte do humano é formal ainda por uma outra razão, que também se manifesta no citado

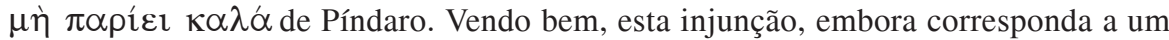
programa perfeitamente contrastado com outros possíveis (e, nesse sentido, a uma

motivgeschichtliche Untersuchungen zu einem Wertbegriff der antiken Literatur, Göttingen, Vandenhoeck \& Ruprecht, 1965, 36ss., B. A. van GRONINGEN, Theognis. Le premier livre, Amsterdam, Noord-Hollandsche Uitgevers, 1966, ad 255-256, G. L. KONIARIS, On Sappho, Fr. 16 LP, Hermes 95 (1967), 257-268, G. A. PRIVITERA, Su una nuova interpretazione di Saffo fr. 16 LP., Quaderni Urbinati di Cultura Classica 4 (1967), 182-187, H. FRÄNKEL, Wege und Formen frühgriechischen Denkens. Literarische und philosophiegeschichtliche Studien, München, Beck, 1968, 91s., E. M. STERN, Sappho Fr. 16 L.P. Zur strukturellen Einheit ihrer Lyrik, Mnemosyne 23 (1970), 348-361, J. DIGGLE, Notes on the Heraclidae of Euripides, Classical Quarterly 22 (1972), 241-245, W. J. FROLEYKS, Der $A \Gamma \Omega N \Lambda O \Gamma \Omega N$ in der antiken Literatur, Diss. Bonn, 1973, 44s., T. KRISCHER, Die logischen Formen der Priamel, Grazer Beiträge2 (1974), 79-91, M. L. WEST (ed.), Hesiod Works and Days, Oxford, Clarendon Press, 1978, ad 293-7, S. des BOUVRIE THORSEN, The Interpretation of Sappho's Fragment 16 L.-P., Symbolae Osloenses 53 (1978) 5-23, B. MARZULLO, Sapph. Fr. 16, 713 V., Museum Criticum 13-14 (1978-1979), 107-111, G. H. BOND (ed.), Euripides Heracles, Oxford, Clarendon Press, 1981, ad 1425s., G. W. MOST, Sappho Fr. 16, 6-7 L.P., The Classical Quarterly 31 (1981), 11-17, W. RACE, The Classical Priamel from Homer to Boethius, Leiden, Brill, 1982, B. GENTILI, Poesia e pubblico nella Grecia antica. Da Omero al V secolo, Roma/Bari, Laterza, 1984, reed., 1995, 136 ss., W. H. RACE, Sappho, Fr. 16 L-P and Alkaios, Fr. 42 L-P: Romantic and Classical Strains in Lesbian Lyric, The Classical Journal 85 (1989), 16-33, P. HAYDEN, Sappho 16, Gorgias' Helen, and the Preface to Herodotus' Histories, Yale Classical Studies 29 (1992), 63-84, J. WILLKINS (ed.), Euripides Heraclidae, Oxford, Clarendon Press, 1993, ad 892-7, B. HUSS, Xenophons Symposion. Ein Kommentar, Stuttgart/Leipzig, Teubner, 1999, 228, A. BIERL, «Ich aber (sage), das Schönste ist, was einer liebt !»: eine pragmatische Deutung von Sappho Fr. 16 LP, Quaderni Urbinati di Cultura Classica 74 (2003), 91-124.

${ }^{99} \mathrm{E}$ isto de tal modo que a vinculação que reina em nós é justamente uma vinculação a esse máximo formal. É para isso que tendemos, é isso que demandamos. Por outras palavras, o terminus ad quem original do $\mu \varepsilon \tau \alpha \xi \hat{v} \kappa \alpha \lambda \circ \hat{v} \kappa \alpha i$ ' $\alpha$ i $\sigma \rho \circ \hat{v}$ é justamente esta instância formal - e não um $\kappa \alpha \lambda o ́ v$ determinado de forma concreta. E toda a nossa relação com um $\kappa \alpha \lambda \delta$ o determinado de forma concreta passa precisamente pelo nexo que ele tem (ou pela forma como se relaciona) com esse máximo formal a que estamos vinculados de raiz. Ou, para o exprimir na linguagem da nota 89 , o enamoramento ou a paixão (ou como se lhe queira chamar), que temos sempre já inscrito e sempre já de algum modo a "levedar" na própria forma como nos achamos constituídos, está de raiz dirigido a esse máximo formal - não a um $\kappa \alpha \lambda$ óv determinado de forma concreta - e a sua relação com qualquer $\kappa \alpha \lambda \omega$ v determinado de forma concreta passa pela relação que sempre já tem com essa instância formal por que de raiz está "sintonizado". 
direcção ou orientação bastante definida), deixa por fixar que é que é preciso para dar cumprimento a tal programa - quais são as coisas belas que se trata de fazer ou encontrar. Ora, este carácter como que enigmático da injunção de Píndaro traduz, com toda a precisão, uma característica da vinculação ao $\kappa \alpha \lambda$ óv que é inerente à constituição do Humano. Pois também aí já está fixada uma direcção fundamental, que é a direcção do belo (da sua obtenção e posse) e não uma outra. Mas, por outro lado, a vinculação está constituída de tal modo que ainda deixa por definir concretamente em que consiste isso para que remete - a que é que corresponde, onde e como se alcança. Quer dizer, há algo de vago, não inteiramente definido, na direcção fundamental do $\mu \varepsilon \tau \alpha \xi \hat{v}$ votado ao $\kappa \alpha \lambda o ́ v$. Porém, não se trata de uma indefinição total: o que há de vago situa-se no quadro da direcção diferenciada já absolutamente fixa (e é introduzido justamente pelo que esta já tem de determinado, enquanto esse algo de determinado encerra, por sua vez, em si uma tarefa de mais precisa ou concreta identificação do seu próprio teor sc. daquilo para que já aponta). $\mathrm{O}$ que, finalmente, nos permite distinguir uma componente decisiva deste carácter meramente formal da vinculação ao Belo e que é a seguinte. A vinculação formal não é indiferente à sua desformalização, não tem o carácter de algo inerte, onde se pára - como se o que ainda comporta de incógnita fosse deixado (ou pudesse ser deixado) assim. Precisamente porque já se está vinculado ao $\kappa \alpha \lambda o ́ v$ (e à preocupação de não o deixar escapar), se aquilo em que o $\kappa \alpha \lambda \delta$ óv consiste se mantém indefinido ou a precisar de concretização, então a própria vinculação a isso suscita a questão da sua desformalização, faz caso dela, pede concretização. De sorte que faz parte da própria vinculação formal constituir em si uma petição (um requisito, ou melhor, uma pressão) de desformalização. E o Humano nunca é só um acontecimento de petição formal do $\kappa \alpha \lambda$ óv, mas sempre também um acontecimento de precisão de desformalização - e na verdade também um acontecimento de efectiva desformalização dessa petição formal, encaminhando nesta ou naquela direcção concreta.

Ora, que o discurso de Sócrates/Diotima tem em vista uma vinculação formal desta ordem (e um concomitante processo de desformalização), isso mostra-se com toda a clareza a partir do segundo e último aspecto que aqui não podemos deixar de considerar: a célebre escala que se desenha em 210ss. Pois trata-se justamente de uma escala de diversos reconhecimentos do $\kappa \alpha \lambda o ́ v$ (ou seja, de diversas desformalizações desta determinação fundamental) ${ }^{100}$.

${ }^{100}$ Antes do mais, uma observação sobre o ponto de partida da escala e o seu significado para a compreensão do que nela está em causa. Ao ler a descrição da escala, pode-se interpretar tudo como se se tratasse do belo, sem qualquer acentuação - e designadamente sem qualquer acentuação quanto ao grau de intensidade daquilo que se situa no seu nível inferior (quer dizer, na própria base da escala). Mas, vendo bem, não parece ser assim. Quando se aponta como

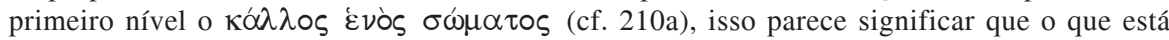
em causa é o fenómeno do enamoramento e a descoberta de beleza fulminante, que lhe é própria (como vimos, justamente aquilo de que se trata no discurso de Agatão). Ora, se é assim, então a escala desenhada por Diotima não é uma escala do belo no sentido (que a palavra belo 
A escala pretende mostrar, em primeiro lugar, que a identificação do que é $\kappa \alpha \lambda$ óv pode variar em função da abertura de ângulo do acesso que se tem. Ou seja, o reconhecimento ou a identificação do $\kappa \alpha \lambda$ ó $\nu$ pode produzir-se em perspectivas de ângulo fechado, que têm um exterior, mas que estão cegas para aquilo que deixam de fora (e tanto quer dizer até cegas para o próprio cabimento de um exterior). O que significa a possibilidade de ocorrência de desconfinamentos ou aberturas de ângulo, resultando em revisões daquilo que parecia assente na óptica fechada que as precede ${ }^{101}$.

também pode ter) de algo provido do seu grau de encanto, sim, mas sem o efeito avassalador, obsidiante, etc., que é preciso para que se chegue a produzir enamoramento. Não. A escala é, se assim se pode dizer, uma escala do belo no sentido forte e pleno do belo enamorante ou, como também poderíamos dizer, do belo fulminante - daquele que provoca $\check{\varepsilon} \kappa \pi \lambda \eta \xi \mathrm{i \varsigma} \mathrm{e}$ tem o efeito descrito, por exemplo, no Phaedrus 250. Quer dizer: na base da escala desenhada por Sócrates e Diotima está precisamente aquilo de que fala o discurso de Agatão. O decisivo está precisamente em que isso que na perspectiva mais corrente (justamente em virtude do tipo de confinamento de óptica que a escala pretende descrever) aparece como o absoluto auge de intensidade do $\kappa \alpha \lambda \sigma \sigma$ (o $\kappa \alpha \lambda \sigma o v$ mais impressionante, superlativamente mobilizador, etc.) passa a figurar, pelo contrário, como forma mínima ou grau ínfimo. Por outras palavras, a escala desenhada por Sócrates e Diotima reduz o Belo ou o ع̌p $p \varsigma$ descrito por Agatão - e que, para Agatão, tem um carácter absolutamente inultrapassável - à condição de mero ponto de partida de um conjunto de possibilidades que em muito o ultrapassam. De sorte que a escala aqui em causa abre como que uma segunda "frente" de ataque ao discurso de Agatão e ao fundamental das suas teses. Esse ataque não tem, como é óbvio, o significado de mera contestação das teses de Agatão. Pois, de facto, Agatão representa toda uma modalidade de desformalização do $\kappa \alpha \lambda \sigma o \nu$, muito frequentemente tida por óbvia, canónica, sem alternativa, e que Sócrates e Diotima pretendem mostrar ser precisamente apenas 1) uma possibilidade (quer dizer, uma possibilidade entre outras) de desformalização do $\kappa \alpha \lambda \delta$ e e, além disso, 2) uma possibilidade que, em última análise, não corresponde efectivamente ao estatuto de superlatividade que faz parte do seu sentido atribuir àquilo que reconhece e consagra.

101 Grosso modo, o itinerário de desconfinamento descrito por Sócrates e Diotima toma como

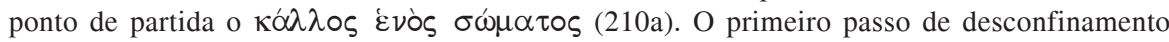
descrito é aquele que dá lugar à descoberta da essencial afinidade que há entre esse momento de $\kappa \alpha \lambda o ́ v$ e outros da mesma ordem, sediados noutros corpos. Ou seja, o primeiro passo dá lugar àquilo que podemos descrever como uma perspectiva que acumula a descoberta do fascínio fulminante de um só corpo com a descoberta de idêntico fascínio em outros (210a-210b). Este alargamento de ângulo acaba por levar a uma perspectiva abrangente, totalizante, já aberta para a totalidade do fascínio que há em todos os diferentes corpos portadores de $\kappa \alpha \lambda o ́ v$, uma perspectiva posta na presença conjunta de todo esse $\kappa \alpha \lambda \sigma \omega v$. Este ângulo alargado faz diminuir

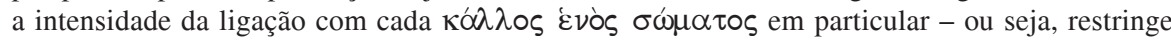
o fascínio e o impacte da forma de $\kappa \alpha \lambda \sigma^{\nu}$ celebrada no discurso de Agatão. Mas a diminuição de intensidade dessa modalidade de $\kappa \alpha \lambda \hat{o} \nu$ resulta do facto de ela se ver ultrapassada e se apequenar em comparação com o extraordinário campo que se abre na nova perspectiva de

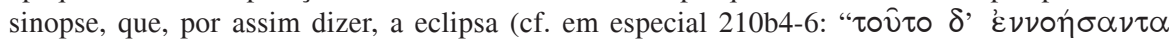

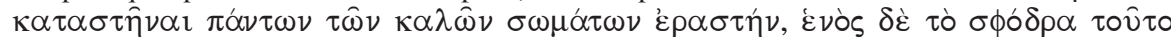

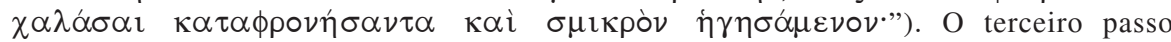
fundamental da escala é aquele que faz transitar de uma óptica ainda inteiramente concentrada na beleza dos corpos para a descoberta do $\kappa \alpha \lambda \sigma^{\nu}$ que tem lugar na própria 


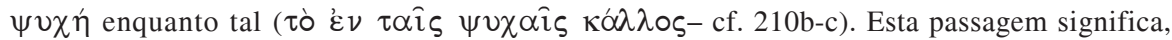
por um lado, uma considerável extensão do campo do $\kappa \alpha \lambda o ́ v$. Mas não se esgota nessa modificação meramente "quantitativa", se assim se pode dizer. Pois, segundo Diotima, implica

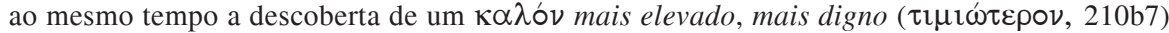
e mais correspondente àquilo que está em causa na petição de $\kappa \alpha \lambda o ́ v$ de que somos portadores. $\mathrm{O}$ passo de desconfinamento que se segue a partir daqui é aquele que conduz à descoberta do

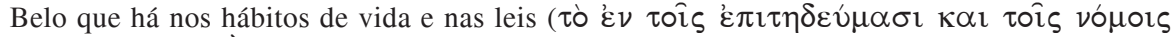
$\kappa \alpha \lambda \delta$ v , 210c3). À semelhança do que foi referido a respeito daquele alargamento de ângulo que leva da percepção da beleza de um corpo à compreensão da sua afinidade com a beleza de outros corpos e, por via disso, à constituição de uma perspectiva de sinopse de toda a beleza dessa ordem, também aqui é apontada como desenvolvimento relevante a descoberta da

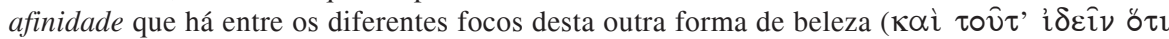

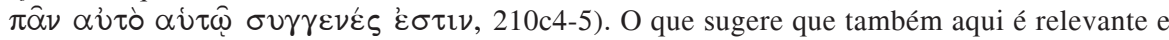
decisiva a passagem para uma perspectiva de captação sinóptica, conjunta deste novo campo de $\kappa \alpha \lambda$ óv. Mas o ascenso ainda prossegue com o novo passo que conduz à descoberta do

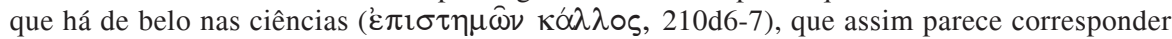
a uma forma de beleza superior a todas as precedentes e de descoberta ainda mais remota do que a delas. Não é mencionado - mas de todo o modo parece sugerido - que o que aqui está em jogo é, de novo, em primeiro lugar, a própria mudança de nível que está implicada na descoberta da beleza deste tipo e, depois, já no novo nível, a progressão que leva da percepção

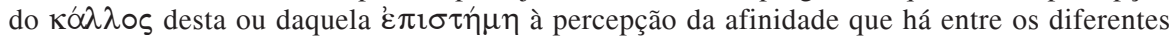
casos de $\kappa \alpha \lambda o ́ v$ deste novo tipo, até que, finalmente, se chega à constituição de uma perspectiva de sinopse, que põe na presença da totalidade do $\kappa \alpha \lambda \hat{\nu} \nu$ pertencente a este plano superior. Seja como for, o discurso acentua, neste passo justamente, o facto de a progressão assim descrita acabar por resultar globalmente numa extraordinária perspectiva de captação conjunta ou sinóptica do Belo. Trata-se aqui já de uma verdadeira sinopse (não, como em cada um dos patamares anteriormente referidos, de sinopses ainda meramente parciais ou regionais, esgotando apenas o campo de visão de ângulos confinados). Esta sinopse é efectivamente abrangente, não circunscrita - e isto de dois modos complementares: por um lado, não se atém a este ou àquele foco de $\kappa \alpha \lambda$ óv (a este ou àquele corpo, a este ou àquele $\dot{\varepsilon} \pi \imath \tau \eta \dot{\delta} \delta \varepsilon \mu \alpha$, podemos também acrescentar: a esta ou àquela $\dot{\varepsilon} \pi \imath \sigma \tau \eta \mu \eta)$, antes cobre a totalidade dos focos de $\kappa \alpha \lambda o ́ v$ em cada nível da presença do belo, de tal modo que é, em cada nível, absolutamente sinóptica; mas, por outro lado, tampouco fica retida num ângulo fechado a que escape algum destes níveis de presença do Belo (o dos $\sigma \omega \mu \alpha \tau \alpha$, o das $\psi v \chi \alpha$ í,

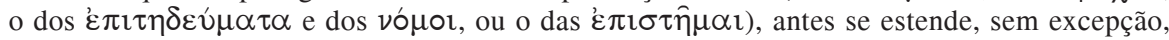
à totalidade deles. Deste modo, eleva-se a perspectiva à descoberta daquilo que, em 210d4, é descrito como o imenso mar do belo ( $\tau \grave{\partial} \pi \circ \lambda \hat{v} \pi \dot{\varepsilon} \lambda \alpha \gamma \circ \varsigma$ $\tau \circ \hat{v} \kappa \alpha \lambda \circ \hat{v})$. Mas a perspectiva elevada à contemplação deste mar também não constitui o termo da ascensão desenhada por Sócrates/Diotima. Pois representa ainda o ponto de partida de um último passo de desconfinamento, onde finalmente se acede àquilo que só por ilusão parecia já atingido em qualquer um dos estádios anteriores (incluindo o primeiro): o $\tau \dot{\varepsilon} \lambda \circ \varsigma \tau \hat{\omega} \nu$ $\varepsilon \rho \omega \tau \iota \kappa \omega \hat{\nu}$ que, segundo Sócrates/Diotima (210e4), só reside no puro $\kappa \alpha \lambda \delta$ o que vem descrito a partir de 210 e6ss. Veja-se a recapitulação de toda a escala em 211b7-d1, que traça com nitidez o

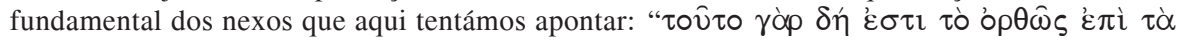

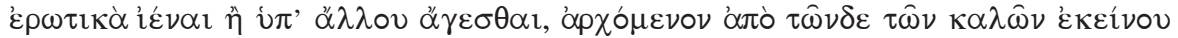

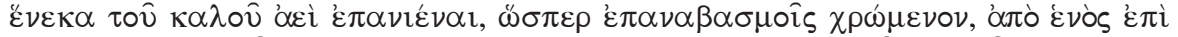

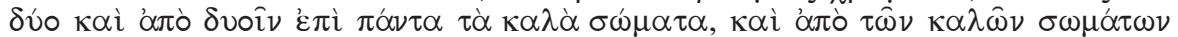

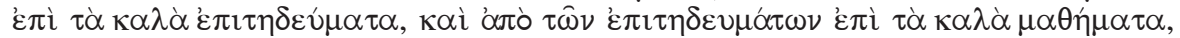

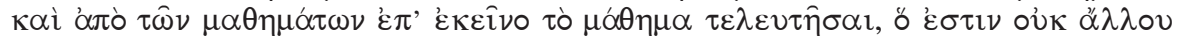

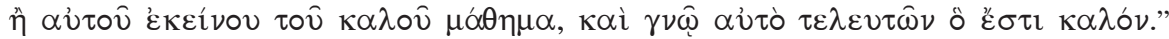


Ou seja, pode-se ter como superlativamente $\kappa \alpha \lambda \sigma^{\nu} \nu$ - e, por isso, identificar com o

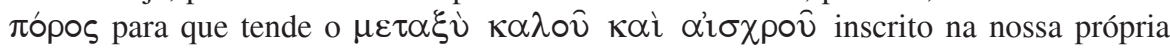
natureza - algo que só chama especialmente a atenção porque se mantêm fora do horizonte outros focos de $\kappa \alpha \lambda \hat{v} v$ mais extraordinário, cuja descoberta eclipsaria (e, ao ocorrer, de facto eclipsa) por completo isso que antes dela já parecia o $\alpha \alpha \lambda o ́ v$ em cheio.

Independentemente do teor concreto da escala sc. dos seus sucessivos estádios, aquilo para que se chama a atenção neste passo decisivo é, antes do mais, isto que também em relação ao Belo não estamos a salvo da prisão em perspectivas unilaterais desta ordem e das surpresas ou peripécias a que tal prisão - e a multiplicidade de passos de desconfinamento a que pode dar lugar - nos expõe. Por outro lado, o que caracteriza a relação entre os diferentes ângulos ou os sucessivos estádios do desconfinamento desenhado nesta escala é que cada nova identificação do $\kappa \alpha \lambda \sigma v$ corrige a anterior. Quer dizer, o que está em causa do princípio ao fim é sempre o mesmo - o $\kappa \alpha \lambda$ ó $v$ para que tendemos e a que aspiramos, em virtude da nossa natureza $\mu \varepsilon \tau \alpha \xi u ́$. Cada passo de desconfinamento mostra que a desformalização anteriormente em vigor resultava da própria limitação do ângulo - e só por limitação do ângulo parecia corresponder já, de modo adequado, ao objecto da petição ou demanda de que somos portadores. Trata-se, portanto, de algo muito parecido com a alegoria da caverna. Nesta, desde o princípio até ao fim, aquilo a que de cada vez se chega é, quanto ao estatuto que se arroga, sempre o mesmo: $\gamma \nu \omega \hat{\sigma} \sigma \mathrm{s} /$ öv (conhecimento daquilo que efectivamente é). Mas, por outro lado, vai-se progressivamente descobrindo que o que parecia ser já isso, de facto, ainda não o era - e só por condicionamento de óptica se prestava a essa identificação ${ }^{102}$. Pode-se, por isso, falar de qualquer coisa como uma Caverna (e isso quer dizer, não o esqueçamos, um labirinto) do Belo, para que Sócrates e Diotima advertem.

102 Assim, já no ponto de partida, quer dizer, no fundo da caverna, os prisioneiros compreendem a sua situação como se o acesso de que dispõem fosse já efectivo conhecimento

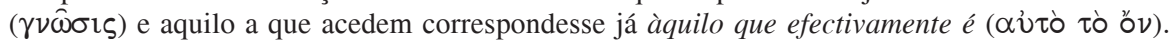
Sobre esta estrutura fundamental e os fenómenos a que corresponde, cf. M. J. de CARVALHO,

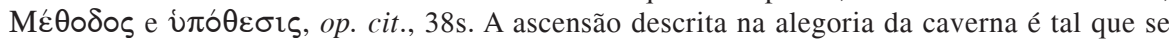
articula numa multiplicidade de passos de alargamento relativo, que de cada vez dá acesso a algo mais elevado, mas de tal modo que esse alargamento sempre de novo deixa subsistir ainda, para lá de si, muito mais do que aquilo que já põe a descoberto. Mas, sendo assim, cada novo patamar do ascenso é percebido como se já esgotasse a totalidade e constituísse, por assim dizer, o máximo, o "alto" absoluto - quer dizer, como se fosse já esse o lugar onde deixa de haver a eliminação, o ângulo fechado, que entretanto se descobriu a limitar as situações de acesso anteriormente ocupadas. Ou seja, cada novo patamar do ascenso é percebido como se fosse já o lugar onde finalmente se cumpre o programa de conhecimento da própria realidade (o estatuto $\gamma \nu \omega \hat{\sigma} \sigma \mathrm{l} /$ ไ̌v) que não só desde o princípio está em jogo, mas desde o princípio se reclama e desde o princípio se julga ter. Nesse sentido, a vincada variação dos diferentes objectos a que sucessivamente se vai ganhando acesso no curso da ascensão (n. b.: a variação do seu grau de realidade, que se exprime na passagem de imagens mais distantes para imagens cada vez mais próximas da própria realidade, mas que, quase até ao termo da ascensão, são, no entanto, ainda imagens) e também a variação da natureza do acesso que sucessivamente 
Mas o mais importante é não perder de vista um outro ponto que é possível divisar já a partir daqui - e que é o seguinte.

Por um lado, aquilo que Sócrates e Diotima desenham é qualquer coisa como uma alegada escala do $\kappa \alpha \lambda o ́ v$ que há ou que pode ser descoberto. Esse é o aspecto mais óbvio. Mas, vendo bem, o que está em causa na escala que apresentam não é apenas isso. Fundida na apresentação disso está, pelas razões que acabamos de expor, uma outra escala, que não depende do que efectivamente haja, pois é a escala do progressivo desdobramento ou descoberta daquilo que está implicado na própria vinculação formal que reina em nós - na exigência de $\kappa \alpha \lambda \delta$ v que se acha inscrita na nossa natureza $\mu \varepsilon \tau \alpha \xi \tilde{v}$. Por outras palavras, se em sucessivos passos de

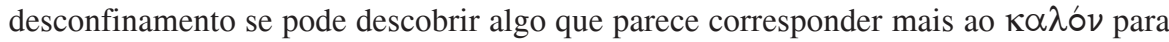

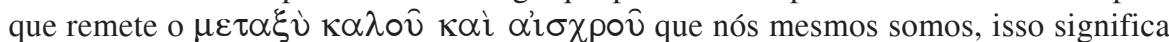
que a própria remissão em causa ou a nossa "vocação para o Belo" não é neutra relativamente a essa variação de mais e menos, antes comporta sempre já em si algo que permite que uns focos de $\kappa \alpha \lambda o ́ v$ lhe correspondam mais do que outros. Quer

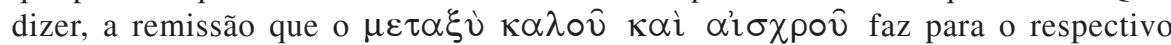
$\pi$ ó $\varsigma_{\zeta}$ está constituída de tal modo que, a despeito do seu carácter meramente formal, tem já (formalmente!) implicadas em si as diferenças de intensidade em causa na escala e, em última análise, remete sempre já (mesmo que apenas formalmente) para o seu topo.

O que, finalmente, nos permite compreender a uma nova luz aquilo que esta escala do Symposium apresenta como seu termo. O texto fala de qualquer coisa como um $\kappa \alpha \lambda$ óv puramente tal - e seria ocioso acentuar como é difícil entender o que isso seja e como é legítimo duvidar que, na verdade, haja (ou até mesmo que em absoluto pudesse alguma vez haver) algo assim ${ }^{103}$. A questão, porém, não se esgota nesse aspecto relativo ao que há ou não há. É também (e é antes do mais) uma questão relativa à própria petição ou demanda que nós somos: ao terminus ad quem, ao $\pi \delta \rho \circ \varsigma$ do $\mu \varepsilon \tau \alpha \xi \hat{v} \kappa \alpha \lambda \circ \hat{v} \kappa \alpha i ̀ ~ \alpha ’ \sigma \chi \rho \circ \hat{v}$ que nos molda. E a este respeito a escala desenhada por Sócrates/Diotima enuncia justamente uma tese: indepen-

se vai obtendo a cada "patamar" de objectos (variação que a alegoria expressa pela progressiva alteração das condições de iluminação, quer dizer, por uma alteração da relação de força entre a luz e a treva que banham e condicionam o acesso a cada patamar de objectos) não impede que o estatuto fundamental daquilo que aparece e do acesso que se tem a isso se mantenha, do princípio ao fim, sempre o mesmo. Pois o estatuto $\gamma \nu \omega \hat{\omega} \sigma i \varsigma / \% ̋ v$ vai sendo transferido de estádio para estádio. Em cada passo de desconfinamento, na ascensão, o estádio em que se estava é desapossado desse estatuto, com transferência deste para o novo estádio que se descobre acima dele - e assim sucessivamente. De onde resulta, por outro lado, que, à medida que se vão sucedendo os passos de desconfinamento descritos na alegoria, aqueles que, em momentos anteriores, reclamavam para si o estatuto $\gamma \nu \hat{\omega} \sigma \mathrm{t} \varsigma / \%$, de que entretanto se viram desapossados, passam a ocupar um lugar definido pela distância que entretanto se interpôs entre eles e o estádio a que passou a ser atribuído o estatuto $\gamma \nu \omega \hat{\sigma} \sigma \iota / / \not \nu \nu$. Para uma análise um pouco mais precisa destes aspectos estruturais da alegoria da caverna, veja-se M. J. de CARVALHO, Die Aristophanesrede in Platons Symposium, op. cit., 553ss.

103 Cf. 210e1-212a7. 
dentemente do que há ou não há, independentemente do que se consegue ou não consegue atingir, em última análise aquilo para que tende a petição de $\kappa \alpha \lambda \delta ́ v$ inscrita em nós (aquilo que, no fundo, procuramos na procura do Belo) seria nem mais nem menos do que a total conversão num $\kappa \alpha \lambda o ́ v$ puramente tal, feito inteiramente, exclusivamente disso ${ }^{104}$. Segundo Sócrates/Diotima, esse é que é o "ponto de fuga"

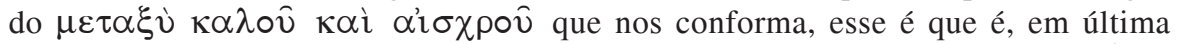
análise, o Belo envolvido na constituição do Humano, essa é que é como que a Ítaca do nosso desassossego - uma Ítaca que até pode não haver ou a que, de todo o modo, porventura temos de renunciar, por não estar ao nosso alcance, mas para que tendemos.

De sorte que nos define também sermos aqueles que, no fundo, mesmo que não tenham clara noção disso, sempre estão na falta e na procura de algo assim.

\section{APÊNDICE I (à nota 29)}

Vejam-se designadamente os elementos que se podem encontrar em J. A. HILD, Étude sur lés démons dans la littérature et la religion des Grecs, Paris, Hachette, 1881, R. C. JEBB (ed.), Sophocles The Plays and Fragments, vol. 2, The Oedipus Coloneus, Cambridge, University Press, 1889, ad 76, 1337, IDEM (ed.), vol. 4, Philoctetes, Cambridge, University Press, 1890, ad 1100, A. DIETRICH, Nekyia, Beiträge zur Erklärung der neuentdeckten Petrusapokalypse, Leipzig/Berlin, Teubner, 1893, 1913², reed., Darmstadt, Wissenschaftliche Buchgesellschaft, 1969, 59, E. ROHDE, Psyche, Seelencult und Unsterblichkeitsglaube der Griechen, Freiburg i. Breisgau, Mohr, 1894, Tübingen, Mohr, 1910 5-6, vol. I, 99, vol. II, 205, 316, H. USENER, Götternamen. Versuch einer Lehre von der religiösen Begriffsbildung, Bonn, F. Cohen, 1896, 291ss., G. KAIBEL, Sophokles Elektra, Leipzig, Teubner, 1896, ad 917, W. WINDELBAND, Platon. Stuttgart, Fromann, 1900, reed. Eschborn, D. Klotz s.d., 124ss., R. C. JEBB (ed.), Bachylides. The Poems and Fragments, Cambridge, University Press, 1905, reed.Hildesheim, Olms, 1994, ad XV, 23, L. ROBIN, La théorie platonicienne de l'amour, Paris, Alcan, 1908, 129ss., J. TAMBORINO, De antiquorum daemonismo, Gießen, Töpelmann, 1909, A. C. PEARSON (ed.), Euripides The Phoenissae, Cambridge, University Press, 1909, ad 1653, C. MICHEL, Les bons et les mauvais esprits dans les croyances populaires de l'ancienne Grèce, Revue d'histoire et de littérature religieuses N.S 1 (1910), 193-215, J. BURNET (ed.), Plato's Phaedo, Oxford, Clarendon Press, 1911, ad 107d6, A. DELATTE, Études sur la littérature pythagoricienne, Paris, Champion, 1915, 68s., L. GERNET, Recherches sur le développement de la pensée juridique et morale en Grèce. Étude sémantique, Paris, Leroux, 1917, 316ss., A. C. PEARSON (ed.), The Fragments of Sophocles, Cambridge, University Press, 1917, vol. II, ad 646, 5, 653,

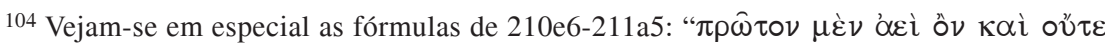

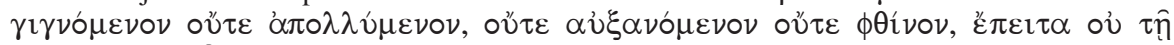

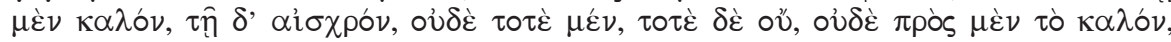

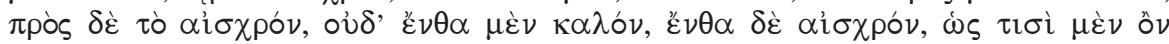
$\kappa \alpha \lambda o ́ v, \tau \imath \sigma i ̀ ~ \delta \dot{\varepsilon} \alpha i \sigma \chi \rho o ́ v . "$ 
1, C. ANDRES, $\Delta \alpha \hat{\imath} \mu \omega \nu$, in: Paulys Realencyclopädie der classischen Altertumswissenschaft Suppl-Bd. 3, Stuttgart, Metzler, 1918, 267-322, S. E. BASSET, $\Delta \alpha i ́ \mu \omega v$, Classical Review 33 (1919), 134-138, A. ROSTAGNI, Il verbo di Pitagora, Torino, Bocca, 1924, 100ss., A. DIÈS, Autour de Platon. Essais de critique et d'histoire, Paris, Beauchesne, 1927, reed. Paris, Les Belles Lettres, 1972², 376ss., 472ss., P. FRIEDLÄNDER, Platon I: Seinswahrheit und Lebenswirklichkeit, Berlin, de Gruyter, 1928, 1954², 34ss., O. KERN, Die Religion der Griechen, vol. 1, Berlin, Weidmann, 1928, 128ss., U. von WILAMOWITZ-MOELLENDORFF, Der Glaube der Hellenen, Berlin, Weidmann, 1931-1932, reimpr. Darmstadt, Wissenschaftliche Buchgesellschaft, 1984, vol. I, 356ss., F. WEHRLI, $\Lambda A \Theta E B I \Omega \Sigma A \Sigma$. Studien zur ältesten Ethik bei den Griechen, Leipzig/ Berlin,Teubner, 1931, 70ss, 74s, 83, 98, P. SHOREY, What Plato Said, Chicago (Ill.), The University of Chicago Press, 1933, 546s. P. BOYANCÉ, Les deux démons personnels dans l'antiquité grecque et latine, Revue de Philologie 61 (1935), 189-202, W. FOERSTER, $\Delta \alpha^{\prime} \mu \omega \nu$, in: G. KITTEL, Theologisches Wörterbuch zum neuen Testament, vol. II, Stuttgart, Kohlhammer, 1935, 1-8, E. LEITZKE, Die Ausdrücke für das Schicksal bei Homer, Glotta 25 (1936) 143-152, P. BOYANCÉ, Le culte des muses chez les philosophes grecs. Études d'histoire et de psychologie religieuses, Paris, de Boccard, 1937, 104ss., 108, 110s, 182s., 192, J. D. DENNISTON, Euripides Electra, Oxford, University Press, 1938, reed. Oxford, Clarendon Press, 1998, ad 1234, G. J. WOLDINGA, Xenophons Symposium, vol. II, Hilversum, Schipper, 1939, 412s., G. KRÜGER, Einsicht und Leidenschaft. Das Wesen des platonischen Denkens, Frankfurt a. M., Klostermann, 1939, 19744 , 52ss., 154s., M. UNTERSTEINER, Il concetto di $\delta \alpha i ́ \mu \omega \nu$ in Omero, Atene e Roma 41 (1939), 93-134, G. PATRONI, La voce äáßìùi in Omero, Accademia Nazionale dei Lincei Rendiconti della Classe di Scienze morali, storiche e filologiche 1 (1940), 99-104, M. P. NILSSON, Greek Popular Religion, N. Y., Columbia University Press, 1940, 19472, 88ss., 109ss., P. C. van der HORST, $\Delta \alpha \hat{i} \mu \omega v$, Mnemosyne 10 (1941) 61-68, O. REVERDIN, La religion de la cité platonicienne, Paris, E. de Boccard, 1945, 127-150, A. LEVI, Sulla demonologia platonica, Athenaeum 24 (1946), 119-128, W. B. STANFORD, The Odyssey of Homer, London, Macmillan \& Co, 1947, 1964², ad II,134-5, vol. II, ad XV, 261-2, W. CHASE GREENE, Moira. Fate, Good and Evil in Greek Thought, Cambridge (Mas.), Harvard University Press, 1948, 12s., 71, 74s., 105, 113s., 158, 178, 255, 306, 310, 315s., E. FRAENKEL (ed.), Aeschylus Agamemnon, Oxford, Clarendon Press, 1950, reed.1974, ad 1057, A.-J. FESTUGIÈRE, Contemplation et vie contemplative selon Platon, Paris, Vrin, 1950, 40, 268ss., T. B. L. WEBSTER, Studies in Menander, Manchester, Manchester University Press,1950, 1960², 196s., G. SOLERI, Politeismo e monoteismo nel vocabulario teologico della letteratura greca da Omero a Platone, Rivista di Studi Classici 8 (1960), 24-56, E. FRAENKEL (ed.), Aeschylus Agamemnon, vol. III, Oxford, Oxford University Press, 1950, reed. Oxford, Clarendon Press, 1998, ad 1341s., E. R. DODDS, The Greeks and the Irrational, Berkeley, University of California Press, 1951, 42, R. B. ONIANS, The Origins of European Thought about the Body, the Mind, the Soul, the World, Time and Fate. New Interpretations of Greek, Roman and Kindred Evidence about Some Basic Jewish and 
Christian Beliefs, Cambridge, University Press, 1951, 118s., 144, 160ss., 402s., 406, J. FANTINI, Theos y daimon en Homero, Helmantica 7 (1951), 3-48, M. P. NILSSON, Geschichte der griechischen Religion, vol. I. München, Beck, 1955, 216ss., W. LUTHER, Weltansicht und Geistesleben: Versuch einer wissenschaftlichen Grundlegung der philosophischen Sprachanalyse an Beispielen aus der griechischen Geistesgeschichte von Homer bis Aristoteles, Göttingen, Vandenhoeck \& Ruprecht, 1954, 54ss., 61, 95, E. FRANK, Begriff und Bedeutung des Daimonischen in der griechischen Philosophie, in: IDEM, Wissen, Wollen, Glauben. Gesammelte Aufsätze zur Philosophiegeschichte und Existentialphilosophie, Zürich, Artemis-Verl., 1955, 51-69, E. BRUNIUS-NILSSON, Daimonie. An Inquiry Into a Mode of Apostrophe in Old Greek Literature, Uppsala, Almqvist \& Wiksell, 1955, J. VAN CAMP / P. CANART, Le sens du mot theios chez Platon, Louvain/Paris, B. Nauwelaerts, 1956, 287ss., G. FRANÇOIS, Le polythéisme et l'emploi au singulier des mots $\Theta E O \Sigma$, $\triangle A I M \Omega N$ dans la littérature grecque d'Homère à Platon, Paris, Bibliothèque de la Faculté de Philosophie et Lettres de l'Université de Liège, 1957, em especial 327ss., E. THUMMER, Die Religiosität Pindars, Innsbruck, Wagner, 1957, 90ss., H. SCHWABL, Zur Theogonie bei Parmenides und Empedokles, Wiener Studien 70 (1957), 278-289, W. KRANZ, Platonica, Philologus 102 (1958), 74-83, em especial 76ss. (= IDEM, Studien zur antiken Literatur und ihrem Fortwirken. Kleine Schriften, Heidelberg, Winter, 1967, 324ss.), M. DETIENNE, La démonologie d'Empédocle, Revue des études grecques 72 (1959), 1-17, J.-P. VERNANT, Aspects mythiques de la mémoire, Journal de psychologie 56 (1959) 1-29 (=IDEM/P. VIDAL-NAQUET, La Grèce ancienne 2 L'espace et le temps, Paris, Seuil, 1991, 15-46), W. SCHMID, Menanders Dyskolos und die Timonlegende, Rheinisches Museum 102 (1959), 157-182, em especial 174, H. NOWAK, Zur Entwicklungsgeschichte des Begriffs Daimon. Eine Untersuchung epigraphischer Zeugnisse vom 5. Jh. v. Chr. bis zum 5. Jh. n. Chr., Diss. Bonn, 1960, A. RIVIER, L'élément démonique chez Euripide jusqu'en 428, in: Euripide. Entretiens sur l'antiquité classique V, Vandœuvres-Genève, Fondation Hardt, 1960, 43-86, C. H. KAHN, Religion and Natural Philosophy in Empedocles' Doctrine of the Soul, Archiv für Geschichte der Philosophie 42 (1960), 3-35, em especial 12ss., (=A. P. D. MOURELATOS (ed.), The Pre-Socratics. A Collection of Critical Essays, Garden City (NY), Anchor/Doubleday, 1974, 397-425), J. GRUBER, Über einige abstrakte Begriffe des frühen Griechischen, Meisenheim a. Glan, Hain, 1963, C. M. BOWRA, Pindar, Oxford, Clarendon Press, 1964, 178s., B. DIETRICH, Death, Fate and Gods. The Development of a Religious Idea in Greek Popular Belief and in Homer, London, Athlone Press, 1965, 14ss., F. A. WILFORD, $\Delta \alpha$ í $\mu \omega v$ in Homer, Numen 12 (1965), 217-232, K. REINHARDT, Vermächtnis der Antike. Gesammelte Essays zur Philosophie und Geschichtsschreibung, Göttingen, Vandenhoeck \& Ruprecht, 1966, 247, J. CARRIÈRE, Démon tragique, Pallas 13 (1966), 7-20, M. MÜHL Die traditionsgeschichtlichen Grundlagen in Platons Lehre von den Dämonen (Phaidon 107 d, Symp. 202e), Archiv für Begriffsgeschichte 10 (1966), 241-270, B. A. Van GRONINGEN, Theognis Le premier livre édité avec un commentaire, Amsterdam, Noord-Hollandsche Uitgevers Maatschappij, 1966, Append. IV, p. 455, Y. BRÈS, La 
psychologie de Platon, Paris, PUF, 1968, 146-148, D. O'BRIEN, Empedocles' Cosmic Cycle. A Reconstruction from the Fragments and Secondary Spources, Cambridge, University Press, 1969, 325ss., 328ss., E. DES PLACES., La religion grecque. Dieux, cultes, rites et sentiments religieux dans la Grèce antique, Paris, Picard, 1969, 113ss., 369, M. DETIENNE, La notion de Daïmôn dans le pythagorisme ancien, Paris, Les Belles Lettres, 1963, 25-27, 33s., 42, 52, 57, 63, 87, 93, 96ss., 113ss. 121ss., 124ss., 129ss., 135, S. JENSEN SKOVGAARD, Dualism and Demonology, The Function of Demonology in Pythagorean and Platonic Thought, With an Introduction on the General Theory of Metaphysics and Religious Dualism and an Appendix on the Interpretation and Pythagorean Background of Republic 524-526c, Copenhagen, Ejnar Munksgaard, 1966, K. KERÉNYI, Der grosse Daimon des Symposion, in: Humanistische Seelenforschung, München /Wien, Langen Müller, 1966, 289-310, em especial 295ss., L. GERNET, Anthropologie de la Grèce antique, Paris, Flammarion, 1982, 24s., A. CAMARERO, Sócrates y las creencias demónicas griegas, Bahía Blanca, Instituto de Humanidades, Universidad Nacional del Sur, 1968, J. STALLMACH, Ate: zur Frage des Selbst- und Weltverständnisses des frühgriechischen Menschen, Meisenheim a. Glan, Hain, 1968, 84ss., A. A. LONG, Language and Thought in Sophocles. A Study of Abstract Nouns and Poetic Technique, London, Athlone Press, 1968, 127, 137, P. T. STEVENS (ed.), Euripides Andromache, Oxford, Clarendon Press, 1971, ad 98, T. MANTERO La demonologia nella tradizione greca, Genova, Tilgher, 1974, M. ISNARDI PARENTE, Platone La Demonologia, in: E. ZELLER/R. MONDOLFO, La filosofia dei Greci nel suo sviluppo storico. Parte II, vol. III 2: Platone e l'Academia antica, Firenze, La Nuova Italia, 1974, 672-678, K. J. DOVER, Greek Popular Morality in the Time of Plato and Aristotle, Oxford, Blackwell, 1974, 80, 138s, 141, S. M. DARCUS, Daimon as a Force in Shaping Ethos in Heraclitus, Phoenix 28 (1974), 390-407, B. UHDE, Zur frühen Bedeutung von $\Delta$ AIM $\Omega N$, Zeitschrift für Missionswissenschaft und Religionswissenschaft 59 (1975), 170-181, J. ter VRUGT-LENTZ, Geister (Dämonen), in: T. KLAUSER et al. (ed.), Reallexikon für Antike und Christentum vol. 9, Stuttgart, Hiersemann, 1976, col. 598-615, K. H. LEE (ed.), Euripides Troades, Bristol Classical Press, 1976, reed. 2001, ad 56, 101, W. BURKERT, Griechische Religion der archaischen und der klassischen Periode, Stuttgart, Kohlhammer, 1977, 278ss., S. M. DARCUS, Daimon Parallels the Holy Phren in Empedocles, Phronesis 22 (1977), 175-190, C. KAHN, The Art and Thought of Heraclitus. An Edition of the Fragments with Translation and Commentary, Cambridge/London, Cambridge University Press, 1977, 260s., M. L. WEST (ed.), Hesiod Works \& Days, Oxford, Clarendon Press, 1978, ad 122-3, H. J. SCHAEFFER, Phronesis bei Platon, Bochum, Brockmeyer 1981, 128s, 150s., D. B. CLAUS, Toward the Soul. An Inquiry into the Meaning of $\psi v \chi \eta$ Before Plato, N. Haven/London, Yale University Press, 1981, 119, 155, J.-P. VERNANT, / P. VIDAL-NAQUET, Mythe et tragédie en Grèce ancienne. Paris, Maspero, 1982, 30ss., R. SCHLESIER, Daimon und Daimones bei Euripides, Saeculum 34 (1983), 267-279, I. J. F. JONG /N. van der BEN, Daimon in Ilias en Odyssee, Lampas 17 (1984), 301-316, J. E. REXINE, Daimon in Classical Greek Literature, Platon 37 (1985), 29-52, W. J. VERDENIUS, A Commentary on Hesiod, Works and Days, vv. 1-382, Leiden, Brill, 1985, ad 122, M. DARAKI, Dionysos et la déèsse terre, Paris, 
Arthaud, 1985, reed. Paris, Flammarion, 1994, 142ss., C. W. WILLINK (ed.), Euripides Orestes, Oxford, Clarendon Press, 1986, ad 394, H. OUDEMANS, Daimon bij Hesiodus en in de Homerische Hymnen, Kleio 16 (1986), 1-22, W. BIEHL, Euripides Kyklos, Heidelberg, Winter, 1986, ad 110, A. GARZYA, La divinità e l'uomo in Teognide, Vichiana 17 (1988), 3-12, S. HALLIWELL (ed.), Plato. Republic 10, Warminster, Aris \& Phillips, 1988, ad 617e1, 620e4, A. MOTTE, La catégorie platonicienne du démonique, in: J. RIES et al. (ed.), Anges et démons. Actes du Colloque de Liège et de Louvain-la-Neuve 25-26 novembre 1987, Louvainla-Neuve, Centre d'Histoire des Religions, 1989, 205-221, V. PIRENNE-DELFORGE, Éros en Gréce: dieu ou démon?, ibidem, 223-239, J. D. MIKALSON, Honor Thy Gods. Popular Religion in Greek Tragedy, Chapel Hill, The University of North Carolina Press, 1991, 22ss., R. PADEL, In and Out of the Mind. Greek Images of the Tragic Self, Princeton (NJ), Princeton University Press, 1992, 54ss., 114s., K. ALBERT, Zum Philosophiebegriff Platons, Gymnasium 99 (1992), 17-33, em especial 23s., B. A. O. WILLIAMS, Shame and Necessity, Berkeley (Calif.), University of California Press, 1993, 16ss., M. I. MÉNDEZ LLORET, El démon: la inteligencia en el mundo, Faventia 15 (1993), 23-38, D. J. MASTRONARDE (ed.), Euripides Phoenissae, Cambridge, Cambridge University Press, 1994, ad 1653, I. KIDD, Some Philosophical Demons, Bulletin of the Institute for Classical Studies 40 (1995), 217-224, R. PADEL, Whom Gods Destroy. Elements of Greek and Tragic Madness, Princeton (NJ), Princeton University Press, 1995, 210s., G. REALE, Eros dèmone mediatore. Il gioco delle maschere nel Simposio di Platone, Milano, Rizzoli, 1997, em especial 166ss., P. PINOTTI, Metaxy, in: S. SETTIS (ed.), I Greci. Storia Cultura Arte Società 2 Una storia greca II Definizione, Torino, Einaudi, 1997, 1117 1129, em especial 1125s., C. PIRAS, Vergessen ist das Ausgehen der Erkenntnis. Eros, Mythos und Gedächtnis in Platons Symposion, Frankfurt a. M., Lang, 1997, 165ss., M. CONCHE, La disproportion d'Achille, in : IDEM, Essais sur Homère, Paris, PUF, 1999, 85-96, K. ALT, Der Daimon als Seelenführer: zur Vorstellung des persönlichen Schutzgeistes bei den Griechen, Hyperboreus 6 (2000), 219-252, E. SUÁREZ DE LA TORRE, La noción de «daimon» en la literatura de la Grecia arcaica y clásica, in: A. PÉREZ JIMÉNEZ/G. CRUZ ANDREOTTI (ed.), Seres intermedios: ángeles, demonios y genios en el mundo mediterráneo, Málaga, Charta Antiqua, 2000, 47-87, M. THEUNISSEN, Pindar. Menschenlos und Wende der Zeit, München, Beck, 2000, 252s., D. O'BRIEN, Empedocles: the Wandering Daimon and the Two Poems, Aevum Antiquum, N. S. 1 (2001), 79-179, J. D. MIKALSON, The «daimon» of «eudaimonia», in: J. F. MILLER/C. DAMON/K. S. MYERS (ed.), Vertis in usum. Studies in Honor of Edward Courtney, München, Saur, 2002, 250258, L. ALBINUS, The Greek Daimon Between Mythos and Logos, in: A. LANGE/ H. LICHTENBERGER/K. F. D. RÖHMHELD (ed.), Die Dämonen: die Dämonologie der israelitisch-jüdischen und frühchristlichen Literatur im Kontext ihrer Umwelt/ Demons: the Demonology of Israelite-Jewish and Early Christian Literature in Context of their Environment, Tübingen, Mohr, 2003, 425-446, M. L. GATTI, Etimologia e filosofia. Strategie communicative del filosofo nel "Cratilo" di Platone, Milano, Vita e Pensiero, 2006, 169ss. 
APÊNDICE II (à nota 36)

Para uma análise mais circunstanciada da noção de $\mu \varepsilon \tau \alpha \xi u ́$, veja-se, por exemplo, N. HARTMANN, Platos Logik des Seins, Gießen, Töpelmann,1909, Berlin, de Gruyter, 1965², 94, 100, 184, 305, 337ss., 398, L. ROBIN, La théorie platonicienne des idées et des nombres d'après Aristote. Étude historique et critique, Paris, Alcan, 1908, reed. Hildesheim, Olms, 1963, IDEM, La théorie platonicienne de l'amour, Paris, Alcan, 1908, reed. Paris, Puf, 1964, A. FARINELLI, La vita è un sogno I. Preludi al dramma di Calderon, Torino, Fratelli Bocca, 1916, 27ss., J. SOUILHÉ, La notion platonicienne d'intermédiaire dans la philosophie des dialogues, Paris, Alcan, 1919, P. NATORP, Platos Ideenlehre. Eine Einführung in den Idealismus,Leipzig, Meiner, 1921, $2^{\mathrm{a}}$ ed. aum., 115s., 186ss., 194ss., 473ss., A. DIÈS, Autour de Platon. Essais de critique et d'histoire, Paris, Beauchesne, 1926, reed. N.Y., Arno Press, 1976, II, IV, §4, pp. 375-384, IV II § 2, 472-485, W. KRANZ, Diotima von Mantineia, Hermes 61(1926), 437-447, 440s., G. CALOGERO, Il Simposio di Platone. Versione e saggio introduttivo, Bari, Laterza, 1928, 34ss., P. FRIEDLÄNDER, Platon I: Seinswahrheit und Lebenswirklichkeit, Berlin, de Gruyter, 1928, 1954², 45ss., L. ROBIN (ed.), Platon, Oeuvres complètes, IV.2, Le Banquet, Paris, Belles Lettres, 1929, reed. 1976, Notice, LXXVIIss., R. DEMOS, Eros, The Journal of Philosophy 13 (1934), 337-45, K. GLASER, Gang und Ereignis des platonischen Lysis, Wiener Studien 53 (1935), 47-67, W. F. R. HARDIE, A Study in Plato, Oxford, Clarendon Press, 1936, 35ss., 117ss., 127ss., H. KOOP, Über die Lehrbarkeit der Tugend. Untersuchungen zum platonischen und nachplatonischen Problem des Lehrens und Lernens, Würzburg-Aumühle, Konrad Triltsch Verlag, 1940, 26ss., 38ss., 66s., R. HACKFORTH, Plato's Divided Line and Dialectic, The Classical Quarterly 36 (1942), 1-9, M. GENTILE, Filosofia e umanesimo, Brescia, La scuola, 1947, 25ss., A.-J. FESTUGIÈRE (ed.), Hippocrate. L'Ancienne Médecine, Paris, Klincksieck, 1948, 47-53, M. LANDMANN, Problematik. Nichtwissen und Wissensverlangen im philosophischen Bewußtsein, Göttingen, Vandenhoeck \& Ruprecht, 1949, 88s., N. BOUSSOULAS, Essai sur la structure du mélange dans la pensée présocratique. Héraclite, Revue de métaphysique et de morale 60 (1955), 287-298, A. WEDBERG, Plato's Philosophy and the Mathematics, Stockholm, Almquist \& Wixell, 1955, 10ss., 84-135, A. C. MOORHOUSE, Studies in the Greek Negatives, Cardiff, University of Wales Press, 1959, 66ss., H. J. KRÄMER, Arete bei Platon und Aristoteles. Zum Wesen und zur Geschichte der platonischen Ontologie, Heidelberg, Winter, 1959, 493ss., N. GULLEY, Plato's Theory of Knowledge, London, Methuen, 1962, 169ss., W. BURKERT, Weisheit und Wissenschaft. Studien zu Pythagoras, Philolaos und Platon, Nürnberg, Carl, 1962, 417ss., K. GAISER, Platons ungeschriebene Lehre. Studien zur systematischen u. geschichtlichen Begründung der Wissenschaften in der Platonischen Schule, Stuttgart, Klett, 1963, 46ss., 89ss., J. A. BRENTLINGER, The Divided Line and Plato's Theory of Intermediates, Phronesis 8 (1963), 146-166, F. CHIEREGHIN, Storicità e originarietà nell'idea platonica, Firenze, Olschki, 1963, em especial 49ss., 76ss., J. M. RIST, Equals and Intermediates in Plato, Phronesis 9 (1964), 27-37, R. C. 
CROSS/ A. D. WOOZLEY, Plato's Republic. A Philosophical Commentary, London/ N.Y., Macmillan/St. Martin's Press, 1964, reed. 1979, 233-238, E. E. HOFFMANN, Methexis und Metaxy bei Plato, in: IDEM, Drei Schriften zur griechischen Philosophie, Heidelberg, Winter, 1964, 29-51, E. HUBER, Anamnesis bei Plato. München, Hueber, 1964, 50s, 69, 299s., 312s., 327ss., 351s., 403s., 418s., 421, 455ss., 460s., 475s., 481s., 539ss., 610, J. WIPPERN, Eros und Unsterblichkeit in der Diotima-Rede des Symposions, in: H. FLASSHAR/ K. GAISER (ed.), Synusia. Festgabe für W. Schadewaldt zum 15. März 1965, Pfullingen, Neske, 1965, 123-159, C. W. MÜLLER, Gleiches zu Gleichem. Ein Prinzip frühgriechischen Denkens, Wiesbaden, Harrassowitz, 1965, 178ss., G. VLASTOS, Degrees of Reality in Plato, in: R. BAMBROUGH (ed.), New Essays on Plato and Aristotle, London, Routledge \& Kegan Paul, 1965, 1-19, M. HARE, Plato and the Mathematicians, ibi, 21-38, 1-19, H. BUCHNER, Eros und Sein. Erörterungen zu Platons Symposion, Bonn, Bouvier, 1965, em especial 55-95, E. SCHMALZRIEDT, Platon. Der Schriftsteller

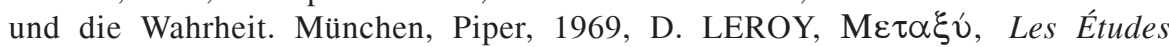
classiques 35 (1967), 321-331, M. J. O'BRIEN, The Socratic Paradoxes and the Greek Mind, Chapel Hill, University of California Press, 1967, 132, J. MOREAU, Le sens du platonisme, Paris, Belles Lettres, 1967, 150ss., H. PETERS, Platons Lysis. Untersuchungen zur Problematik des Gedankenganges und zur Gestalt des Kunstwerks, Witterschlick b. Bonn, Schwarzbold, 1968, 60ss., 136ss., E. TIELSCH, Die platonischen Versionen der griechischen Doxalehre. Ein philosophisches Lexikon mit Kommentar, Meisenheim Gl., Hain, 1970, 60ss., 109ss., 126s., M. DELCOURT, Utrumque-Neutrum, in: A. BAREAU (ed.), Mélanges d'histoire des religions: offerts à Henri-Charles Puech, Paris, Presses Universitaires de France, 1974, 117-123, M. DIMITRAKÓPOULOS, Die 'Mischung' und das Reine in der platonischen Dialektik, Diss. Freiburg i. Br., 1974, R. J. FOGELIN, Three Platonic Analogies, Philosophical Review 83 (1974), 371-382, W. K. C. GUTHRIE, A History of Greek Philosophy IV Plato The Man and His Dialogues Earlier Period, Cambridge, Cambridge University Press, 1975, 342ss., 385s., 509s., 523, J. ANNAS, On the Intermediates, Archiv für Geschichte der Philosophie 57 (1975), 146-166, L. M. NAPOLITANO, Sul rapporto tra matematica e dialettica in Platone, Atti del Istituto Veneto di Scienze, Lettere ed Arti 134 (1975-1976), 285-310, F. C. WHITE, Plato on Knowledge and Reality, Indianapolis, Hackett, 1976, 109s., F. C. WHITE, The "Many" in Republic 475e-480a, Canadian Journal of Philosophy 7 (1977), 291-306, J. C. B. GOSLING, Reply to White, Canadian Journal of philosophy 7 (1977), 307-314, A. P. D. MOURELATOS Nothing as Not Being. Some Literary Contexts that Bear on Plato, in: G. BOWERSOCK/W. BURKERT/M. PUTNAM (ed.), Arktouros. Hellenic Studies Presented to Bernard M. W. Knox on the Occasion of his 65. Birthday, Berlin/N.Y., De Gruyter, 1979, 319-29, em especial 328s., E.

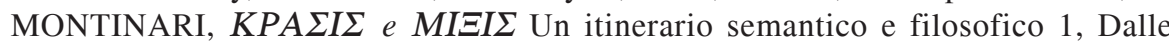
origine ad Eraclito, Firenze, Clusf, 1979, W. SCHWABE, Mischung" und "Element" im Griechischen bis Platon: wort- und begriffsgeschichtliche Untersuchungen, insbesondere zur Bedeutungsentwicklung von "stoicheion", Bonn, Bouvier, 1980, H. D. VOIGTLÄNDER, Der Philosoph und die Vielen. Die Bedeutung des 
Gegensatzes der unphilosophischen Menge zu den Philosophen (und das Problem des argumentum e consensu omnium) im philosophischen Denken der Griechen bis auf Aristoteles, Wiesbaden, Steiner, 1980, 166, 170, 172ss., G. MICHELI, Kant storico della filosofia, Padova, Antenore, 1980, 102s., 110s., R. DESJARDINS, Between the Horns of Dilemma: Dreaming and Waking Vision in Plato's Theaetetus, Ancient Philosophy 1 (1981), 109-126, R. D. MOHR, The Number Theory in Plato's Republic and Philebus, Isis 72 (1981), 620-627, W. WIELAND, Platon und die Formen des Wissens, Göttingen, Vandenhoeck \& Ruprecht, 1982, 212, M. WHITBY, Quasi-elements in Aristotle, Mnemosyne 35 (1982), 225-247, C.-A. SCHEIER, Schein und Erscheinung im platonischen Symposion, Philosophisches Jahrbuch 90 (1983), 363-374, em especial 369, G. REALE, Per una nuova interpretazione di Platone: rilettura della metafisica dei grandi dialoghi alla luce delle "Dottrine non scritte", Milano, Ed. CUSL, 1984, H. HERTER, Die gute Mittellage bei Platon, in: H. M. OELBERG/G. SCHMIDT (ed.), Sprachwissenschaftliche Forschungen. Festschrift für Johann Knobloch. Zum 65. Geburtstag am 5. Januar 1984 dargebracht von Freunden und Kollegen, Innsbruck, Institut für Sprachwissenschaft, 1985, 147155, N. COOPER, Between Knowledge and Ignorance, Phronesis 31 (1986), 229242, G. ROMEYER-DHERBEY, L'âme est, en quelque façon, tous les êtres. Aristote, De anima, Г 8.431b21, Elenchos 8 (1987), 363-380, U. GALIMBERTI, Gli equivoci dell'anima, Milano, Feltrinelli, 1987, 2003², 106ss., K. ALBERT, Über Platons Begriff der Philosophie, St. Augustin, Academia, 1989, 20ss., G. E. PINOTTI, Error y memoria (Platón, Teeteto 190e-195b), Revista Latinoamericana de Filosofía 15 (1989), 5-18, R. DESJARDINS, The Rational Enterprise, Albany (N. Y.), State University of N. Y. Press, 1990, 109s., A. GRAESER, Platons Auffassung von Wissen und Meinen in Politeia V, Philosophisches Jahrbuch 98 (1991), 365-388, C. MARCELLINO, I $\mu \varepsilon \tau \alpha \xi v ́$ nella Repubblica: loro significato e loro funzione, Rivista di filosofia neoscolastica 84 (1992), 410-467, P. M. STEINER, Psyche bei Platon, Göttingen, Vandenhoeck \& Ruprecht, 1992, 107ss., D. FREDE, Out of the Cave: What Socrates Learned from Diotima, in: R. M. ROSEN/J. FARRELL (ed.), Nomodeiktes. Greek Studies in Honor of Martin Oswald, Ann Arbor, The University of Michigan Press, 1993, 397-422, em especial 404ss., B. MARZULLO, I sofismi di Prometeo, op. cit., 251ss., P. HADOT, Qu'est-ce que la philosophie antique?, Paris Gallimard, 1995, 74ss., M. J. de CARVALHO, Problemas fundamentais de fenomeno-logia da finitude, op. cit., vol. II, 1433ss., vol. III, 318ss., E. BAE, Soul and Intermediates in Plato's Phaedo, Diss. University of California, Los Angeles, 1996, E. E. BENITEZ, Republic 476d2-e2. Plato's Dialectical Requirement, Review of Metaphysics 49 (1996), 515-546, K. SIER, Die Rede der Diotima, op. cit., 20ss., 27s., 49, 50ss., 59ss., G. REALE, Il discorso di Socrate sull'Eros. Il gioco drammaturgico incrociato di tre maschere fatto da Platone nel Simposio per la rivelazione della verità sull'Eros, in: H.-C. GÜNTHER et al. (ed.), Beiträge zur antiken Philosophie. Festschrift für W. Kullmann, Stuttgart, F. Steiner, 1997, 59-80, em especial 67-72, G. REALE, Eros dèmone mediatore. Il gioco delle maschere nel Simposio di Platone, Milano, Rizzoli, 1997, 164ss., M. BORDT (ed.), Platon Lysis, Göttingen, Vandenhoeck \& Ruprecht, 1998, 191ss., P. PINOTTI, Metaxy, in: S. 
SETTIS (ed.), I Greci. Storia Cultura Arte Società 2 Una storia greca II Definizione. Torino, Einaudi, 1997, 1117-1129, C. PIRAS, Vergessen ist das Ausgehen der Erkenntnis. Eros, Mythos und Gedächtnis in Platons Symposion, Frankfurt a. M., Lang, 1997, 95ss., 168, M. VEGETTI (ed.), Platone, La Repubblica IV-Libro V, Napoli, Bibliopolis, 2000, 28ss., 102, 376ss., U. CURI, La forza del sguardo, Torino, Bollati Boringhieri, 2004, 169, 186, 204, 207, F. C. C. SHEFFIELD, Plato's Symposium. The Ethics of Desire, Oxford, Oxford University Press, 2006, 42ss., K. EMING, Tumult und Erfahrung. Platon über die Natur unserer Emotionen,

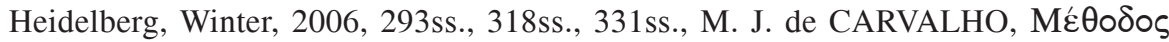
e $\dot{\pi \delta} \theta \varepsilon \sigma ı \varsigma$ - o problema do pressuposto na fundação platónica da filosofia, op. cit., 9-69.

\section{APÊNDICE III (à nota 84)}

Em primeiro lugar, $\delta \alpha i ́ \mu \omega \nu$ é usado aqui sem qualquer espécie de conotação negativa, para indicar algo de superior a nós (podíamos, nesse sentido, dizer que algo de divino). É isso que corresponde ao sentido do termo na tradição antiga, onde era usado justamente para exprimir o superior ou o divino, em especial, quando tinha um carácter indeterminado e não se prestava a ser identificado com nenhuma das divindades do panteão ${ }^{105}$.

Em segundo lugar, parece claro que, ao sugerir aquilo que sugere, Diotima explora um outro aspecto da concepção tradicional de $\delta \alpha i ́ \mu \omega v$ : o $\delta \alpha \hat{i} \mu \omega \nu$ enquanto algo superior a nós, que nos ultrapassa, mas que, ao mesmo tempo, impende sobre nós - sujeitando-nos ao seu poder e ao seu efeito. Nesse sentido, o Humano é definido por Diotima como algo posto sob o efeito de um poder que o ultrapassa. Mas, por outro lado, há ainda um terceiro aspecto que importa pôr em relevo. Tal como aparece concebido por Diotima, esse algo que nos ultrapassa não intervém no humano de forma puramente ocasional, avulsa, por acessos. Para Diotima, trata-se, muito pelo contrário, de algo permanente e constitutivo, que acompanha a vida humana desde o princípio até ao fim, de tal modo que tudo nela está posto sob o seu efeito - é segundo ele. ${ }^{106}$ Também este aspecto da concepção desenvolvida por

105 Ou então também para exprimir uma forma limitada, não plena, de poder divino. Um dos traços do uso de $\delta \alpha \hat{i} \mu \omega \nu$ é precisamente a flexibilidade ou plasticidade da noção, que comporta diversos cambiantes e permite a acentuação (tanto separada quanto conjunta) desses diversos cambiantes - desde o carácter não identificado ou desconhecido do poder superior em causa até à própria ideia de qualquer coisa como um "deus menor" (que constitui, sem dúvida, um dos antecedentes do uso da noção no discurso de Sócrates/Diotima).

${ }^{106} \mathrm{Cf}$., por exemplo, a descrição da escolha do $\delta \alpha i ́ \mu \omega \nu$ no livro X da Respublica, 617d6-

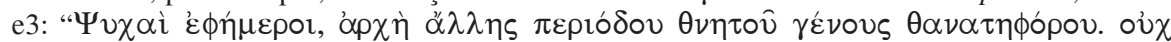

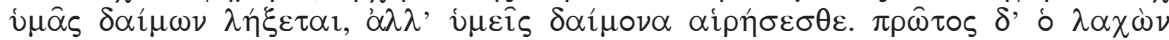

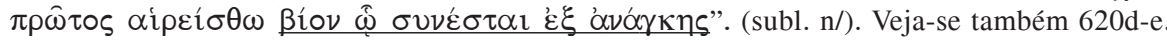


Diotima tem alguns traços de continuidade com a tradição anterior. Por uma parte,

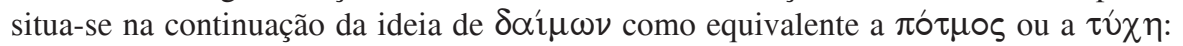
o destino ou o lote que toca a um dado ente. Mas, por outra parte, Diotima determina essa noção num sentido que também encontra antecedentes noutros textos da tradição antiga. Pois, neste caso, o que está em causa não é o destino ou o lote de um

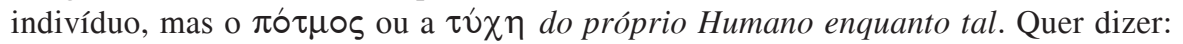
cabe-nos em sorte, de raiz, enquanto humanos, estarmos sob o efeito deste poder, que faz de nós o que nós somos, tal como um "destino" ( $\pi \delta$ $\tau \mu \circ \zeta, \tau u ́ \chi \eta)$ determina e molda aquele a quem cabe em sorte.

Isto por um lado. Mas há um outro aspecto que também importa ter em atenção.

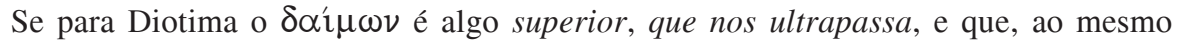
tempo, impende e actua sobre nós, nos move, etc., esse impender e esse ultrapassar não ocorrem na forma de algo de exterior, que, de algum modo, esteja "colado" a nós ou o que quer que seja desse género. Não. Na perspectiva de Diotima, trata-se de algo superior, que nos ultrapassa, sim, mas que está em nós no modo como o superior que é a eternidade está na vida (enquanto instância intermédia entre a mortalidade e a imortalidade) ou como o superior que é o saber está na própria constituição do $\phi ı \lambda \circ \sigma o \phi \varepsilon i v \nu$, da procura (sc. da peculiar forma de acesso ou notícia que o possibilita). Quer dizer: o superior, aquilo que nos ultrapassa, está em nós e impende, actua sobre nós porque está implicado no próprio fulcro daquilo que nos faz - i.e., porque é constitutivo, no sentido próprio e pleno do termo. ${ }^{107}$ Também neste ponto a perspectiva desenvolvida por Diotima vem dar continuação à tradição, já iniciada antes de Platão, daquilo a que podemos chamar, grosseiramente, a "incorporação" ou "naturalização" do $\delta \alpha \hat{\imath} \mu \omega \nu$ - quer dizer, à tradição da sua compreensão como algo de inerente, não superveniente, que pertence à própria constituição do ente em que intervém

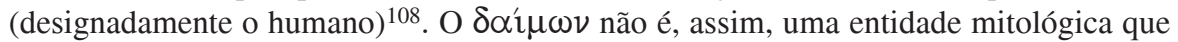
"ande aî", algures, mas sim algo que "anda" permanentemente em nós e, na verdade, de tal modo que nós mesmos somos (somos de raiz e no próprio fulcro daquilo que

$107 \mathrm{Ou}$, mais precisamente, porque é constitutivo no sentido de aquilo que nós somos, por sua própria natureza, tender para isso, - ser, por sua própria natureza, uma procura, um projecto disso: uma tentativa de alcançar isso, a $\pi \varepsilon v i ́ \alpha$ votada ao $\pi$ ópos disso.

108 É algo dessa ordem que se encontra já em HERACLITO, DK 22 B 119, muito provavelmente em EMPÉDOCLES, DK 31 B 59 (veja-se v. g. D. O'BRIEN, Empedocles' Cosmic Cycle. A Reconstruction from the Fragments and Secondary Sources, Cambridge, University Press, 1969, 325ss., em especial 328ss., J. BARNES, The Presocratic Philosophers, vol. 2, London, Routledge \& Kegan Paul, 1979, 196s., M. R. WRIGHT, Empedocles The Extant Fragments, New Haven/London, Yale University Press, 1981, 69ss., 271ss., B. INWOOD (ed.), The Poem of Empedocles, Toronto /Buffalo, University of Toronto Press, 1992, 53ss.,I. KIDD, Some Philosophical Demons, Bulletin of the Institute for Classical Studies 40 (1995), 217-224, em especial 222ss.), ou também, por exemplo, em DEMÓCRITO, DK 68 B 171, em EPICARMO DK 23 B 17, também Fr 87, 6, apud C. AUSTIN (ed.), Comicorum Graecorum fragmenta in papyris reperta, Berlin, De Gruyter, 1973, ou ainda em XENÓCRATES, tal como se acha citado por ARISTÓTELES, Topica, 112a36-38, só para dar alguns exemplos. 


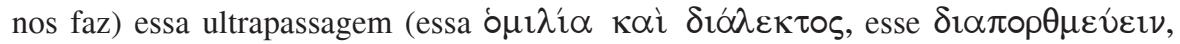
etc.) para lá do que somos ${ }^{109}$.

Finalmente, sejam quais forem os traços de afinidade ou continuidade que há entre o uso pré-platónico e coevo da noção de $\delta \alpha i ́ f \omega \nu$ e o sentido que ela assume no discurso de Sócrates/Diotima, o ponto decisivo é precisamente a radical modificação introduzida neste discurso e que transfigura os próprios aspectos em que há afinidade ou pontos de contacto. Tudo o que acabamos de ver acerca das linhas de continuidade entre o $\delta \alpha i ́ \mu \omega \nu$ descrito por Sócrates/Diotima e os seus antecedentes assume um significado muito particular porque, na óptica do discurso, aquilo que propriamente define o $\delta \alpha \hat{\imath} \mu \omega \nu$ enquanto tal (ou seja, aquilo que define o superior de certo modo indefinido, o poder divino limitado que impende sobre nós e nos move, a $\tau \hat{\chi \chi \eta ~ o u ~ o ~ \pi o ́ \tau \mu o \zeta ~ a ~ q u e ~ e s t a m o s ~ e n t r e g u e s, ~ e t c .) ~ e ́ ~ p r e c i s a m e n t e ~ o ~ s e r ~} \delta \alpha \hat{\imath} \mu \omega \nu$ no sentido novo introduzido por Sócrates/Diotima: essa peculiar miscigenação do separado, essa mestiçagem de cá e lá (ou, mais propriamente, uma multiplicidade de híbridos ou mestiçagens de ter e não ter, de alcance e do contrário) - ou seja, essa condição atravessada, a meio caminho entre margens, incapaz de redução a qualquer uma delas - que o discurso procura descrever.

\section{APÊNDICE IV (à nota 52)}

Dizendo-se assim, simplifica-se consideravelmente um estado-de-coisas na verdade bastante mais complexo, mas aponta-se, de todo o modo, na direcção de qualquer coisa cum fundamento in re. Aquilo que de facto se encontra desenhado no corpus da literatura antiga é um conjunto de noções ( $\pi \varepsilon v i ́ \alpha$, $\alpha \mu \eta \chi \alpha \nu^{i} \alpha$,

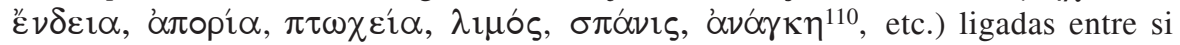
por relações de co-pertença e também pela forma como se contrapõem a um conjunto

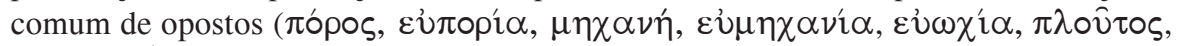

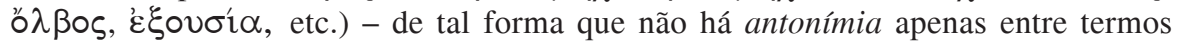

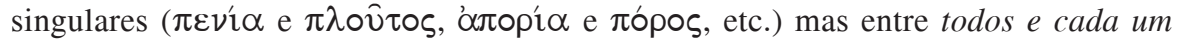
dos membros de uma das séries e todos e cada um dos membros da outra. A ligação entre essas diversas noções é mais flagrante e insistente nuns casos do que nos

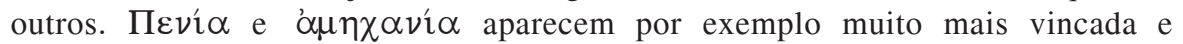
frequentemente irmanadas do que $\pi \varepsilon v^{\prime} \alpha$ e $\alpha \pi$ opí $\alpha$ - cuja ligação se encontra

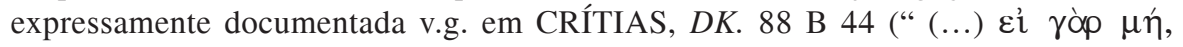

109 Justamente o que também vale para $\varepsilon \rho \omega \varsigma$, como resulta claro de tudo o que

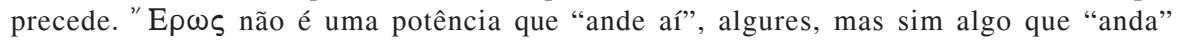
permanentemente em nós, enquanto somos uma realidade múlipla e pervasivamente constituída de raiz na forma de ع̌ $\rho \omega \varsigma$, múltipla e pervasivamente "desiderativa" - ou, o que é o mesmo, múltipla e pervasivamente $\mu \varepsilon \tau \alpha \xi u ́$, múltipla e pervasivamente $\delta \alpha i ́ \mu \omega \nu$.

110 Sobre $\alpha \nu \alpha ́ \gamma \kappa \eta$ neste sentido, veja-se, por exemplo, F. M. CORNFORD, Thucydides Mythistoricus, London, Arnold, 1907, 223s. e W. HEADLAM/G. THOMPSON (ed.), The Oresteia of Aeschylus, vol. II, Amsterdam/Prague, Hakkert/Academia, 1966, ad Agam. 218. 


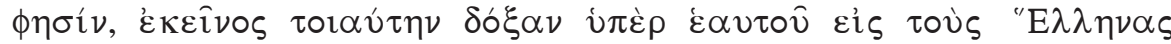

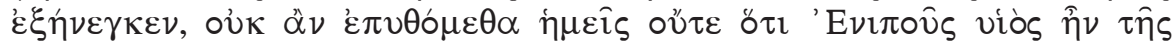

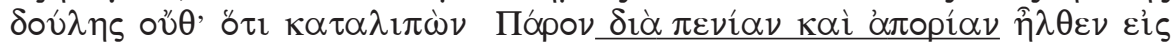

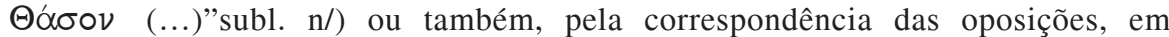

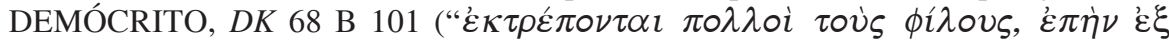

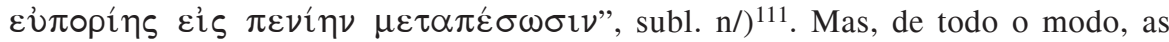
situações vividas como situações de " $\pi \varepsilon v i \alpha$ " (" $\alpha \mu \eta \chi \alpha \nu i ́ \alpha$ ", etc.) são vividas precisamente como situações de falta de $\pi \delta$ ó modo que justamente se exprime nas próprias expressões $\alpha-\mu \eta \chi \alpha v^{\prime} \alpha, \alpha$, $\alpha-\pi$ opí $\alpha$, onde o alfa privativo traduz a falta em causa). De sorte que os dois termos, $\pi \varepsilon v i ́ \alpha$ e

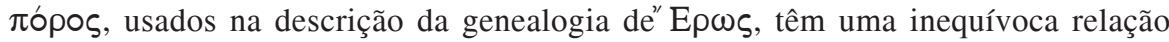
de antonímia não menos forte e não menos vincada do que se tratasse declaradamente

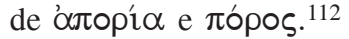

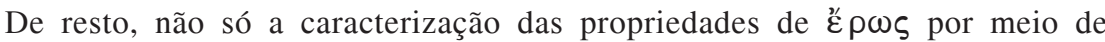
oxímoros tem uma larga tradição na própria literatura anterior a Platão (cf., por exemplo, os trabalhos de F. LASSERRE, La figure d'Eros dans la poésie grecque, Lausanne, Imprimeries Réunies, 1946, E. FISCHER, Amor und Eros. Eine Untersuchung des Wortfeldes "Liebe" im Lateinischen und im Griechischen, Hildesheim, Gerstenberg, 1973 e A. CARSON, Eros. The Bittersweet, Princeton (NJ), Princeton University Press, 1986), mas, como aponta LASSERRE, op. cit., pp. 111s. (cf. também 121s., 124s.), nem sequer é inteiramente inédito, em relação a ع́p $\omega \varsigma$,

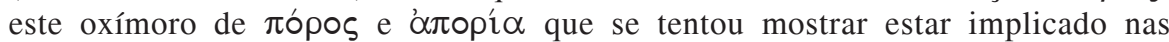

111 Deve-se, aliás, ter presente que, para além dos outros usos com que os "leitores

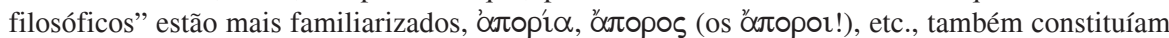
categorias "económicas", frequentemente usadas para expressar a escassez ou a ausência de recursos, a penúria, as pessoas afectadas por essa escassez ou penúria, etc. Veja-se, por exemplo, PLATÃO, Respublica, 465c, 552a, ARISTÓTELES, Politica, 1279b, 1289b, 1290a, 1291b, 1294a, 1295b, 1297a, 1309a, 1315a, 1316b, 1317b, U. von WILAMOWITZ-MOELLENDORFF, Platon. Sein Leben und seine Werke, ed. B. Snell, Berlin/Frankfurt a. M., Weidmann, 194833, 299 e H. BOLKENSTEIN, Wohltätigkeit und Armenpflege im vorchristlichen Altertum, Utrecht, A. Oosthoek, 1939, reed. N.Y., Arno Press, 1979, 183.

112 A expressão de nexos de antonímia, não por meio dos termos mais "literal-

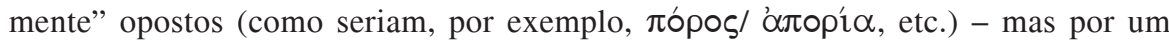
outro membro daquilo a que chamámos a série oposta aparece com certa frequência nos textos antigos. Veja-se, por exemplo, dentro deste mesmo campo semântico,

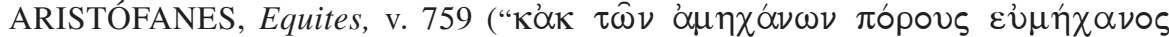

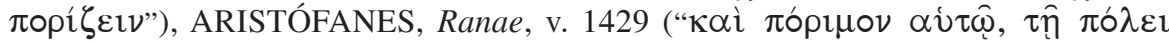

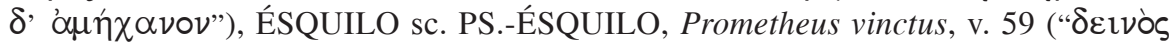

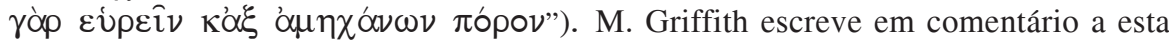

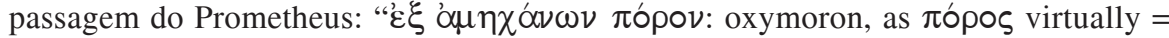

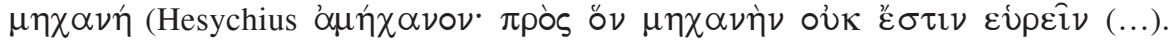
Cf. M. GRIFFITH (ed.), Aeschylus Prometheus Bound, Cambridge, Cambridge University Press, 1983, ad 59. 
formulações do Symposium — de facto há o antecedente do fragmento 2 de ARISTARCO (SNELL, Tragicorum Graecorum Fragmenta, I, 91):

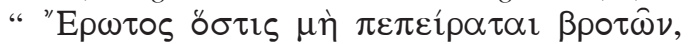

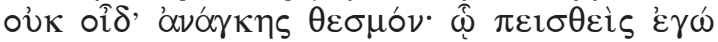

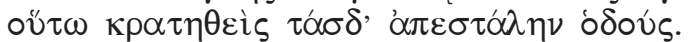

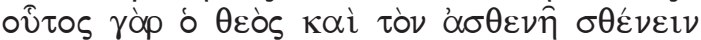

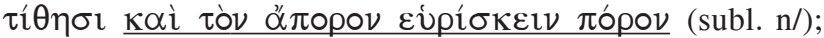

a esse antecedente está dado seguimento na primeira versão do Hippolytus de

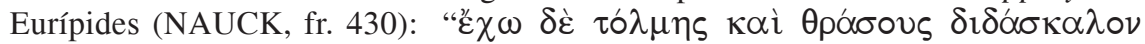

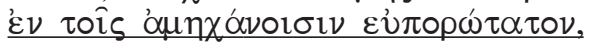

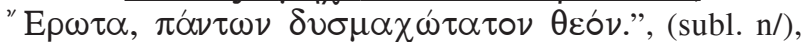
estabelecendo-se assim uma tradição que, além de PLATÃO, é retomada mais tarde também no Traumatias de ALÉXIS, fr. 234, vv. 5-6 (KOCK, Comicorum Atticorum Fragmenta, I, 382):

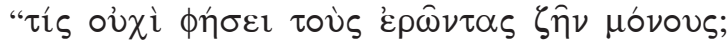

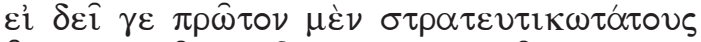

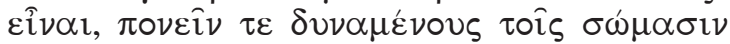

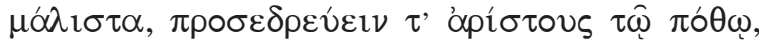

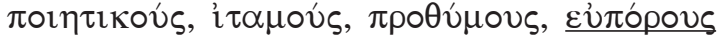

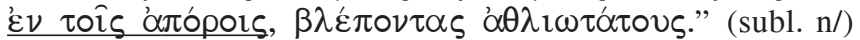

Para se obter um conspecto do uso de $\pi \varepsilon v i ́ \alpha$ e do complexo de noções a que se acha associado, v/, por exemplo, ALCEU, Fr. 142 D, 364 P, TEÓGNIS, Elegiae, vv. 139ss., 155-158, 173ss., 294, 351ss., 383ss., 386s., 583ss., 619s., 645s., 649ss., 683ss., 1075ss., 1115, HESÍODO, Opera, vv. 496s., 638, 717s., SEMÓNIDES, Fr. 7, 101, DEMÓCRITO, DK 68 B 24, 101, 219, 251, 283, 284, CRÍTIAS, DK 88 B 44, GÓRGIAS, DK 82 B 11a, HERÓDOTO, Historiae, VII, 102, VIII, 111, BAQUÍLIDES, I, 61, ÉSQUILO, Prometheus vinctus, v. 59, SÓFOCLES, Fr. 88, 354, 944, 1137 (Radt), EURÍPIDES, Electra, vv. 38, 374s., Hercules, vv. 303ss., Supplices 238-245, Fr. 54, 230, 248, 285, 430, 641, 886, 1059, ARISTÓFANES, Equites, v. 759, Ranae, v. 1429, Pax, v. 207, Plutos, vv. 442ss, Ecclesiazusae 605, DÍFILO, Fr. 105, TÍMOCLES, Fr. 28, FILÉMON, Fr. 92, 96, 102, 157, TUCÍDIDES, II, 37, III, 45, XENOFONTE, Memorabilia, IV, 2, 37-38, PS.-XENOFONTE, Atheniensium respublica I, 2, I, 4-5, II, 9, PLATÃO, Apologia 23c, 31c, Respublica, 421d-e, 465c, 551c-d, 552a, 552b, 557a, 567a, 618a-c, ARISTÓTELES, Politica 1252b, 1266b, 1270b, 1271a, 1279b 1294b, 1295b, 1318a, 1319a (a recensão baseia-se, em parte, nos levantamentos apresentados por NEWIGER, p. 163, MARTIN, p. 102 e WEST, p. 283, citados infra). É também relevante a oposição entre $\pi \varepsilon v i ́ \alpha$ e $\not \lambda \beta o \zeta$, tal como aparece, por exemplo, em EURÍPIDES, Supplices, 176, Hercules, 588s., 647s., Fr. 326, 6s., Fr. 641, 2s. (passos coligidos por A. HARDER, Euripides' Kresphontes and Archelaos, Leiden, Brill, 1985, ad Fr. 230, p. 211). " O $\lambda$ ßo

113 Veja-se, por exemplo, F. WEHRLI, $\Lambda A \Theta E B I \Omega \Sigma A \Sigma$. Studien zur ältesten Ethik bei den Griechen, Leipzig/Berlin, Teubner, 1931, 34s., C. de HEER, MAKAP EY $O \Lambda B I O \Sigma$ EYTYXH . A Sudy of the Semantic Field Denoting Happiness in Ancient Greek 
etc. ${ }^{113}$ Esse tipo de oposição é significativo, porque aponta a carga semântica que à partida, por simples associação, tende a recair sobre o oposto de $\pi \varepsilon v i ́ \alpha$.

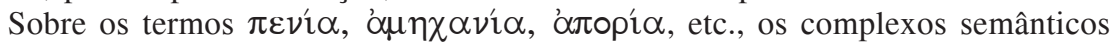
que lhes correspondem e as suas ligações, cf. designadamente: J. H. H. SCHMIDT, Synonymik der griechischen Sprache, vol. II, Leipzig, Teubner, 1878, 611ss., R. C. JEBB (ed.), Bacchylides The Poems and Fragments, Cambridge, University Press, 1905, reed. Hildesheim, Olms, 1994, ad I, 60s., G. MEYER, Laudes inopiae, Diss. Göttingen, 1915, A. C. PEARSON (ed.), The Fragments of Sophocles, Cambridge, University Press, 1917, vol. II, ad 354, 5ss., vol. III, ad 835, 944, J. HEMELRIJK, ПENIA en П $1 O Y T O \Sigma$, Amsterdam, Sloterdijk, 1925, reed. N. Y., Arno Press, 1979, E. GRASSI, Il problema della metafisica platonica, Bari, Laterza, 1932, 72s., R. G. BURY (ed.), The Symposium of Plato, Cambridge, Heffer, 1932, XLs., E. von IVÁNKA, Die Quelle von Ar. Probl. XXVIII, 4, Wiener Studien 53 (1935), 147-150, F. VOIGT, Penia, in: K. ZIEGLER et al. (ed.), Paulys Realencyclopädie der classischen Altertumswissenschaft, vol. 19.1, Stuttgart, Metzler, 1937, 495-497, H. BOLKENSTEIN, Wohltätigkeit und Armenpflege im vorchristlichen Altertum, Utrecht, A. Oosthoek, 1939, reed. N.Y., Arno Press, 1979, 182s., J. D. DENNISTON (ed.), Euripides Electra, Oxford, Clarendon Press, 1939, ad 253, 376, G. J. WOLDINGA, Xenophons Symposium, vol. II. Hilversum, Schipper, 1939, 277s., A. S. GOW (ed.), Theocritus. With a Translation and Commentary, Cambridge, University Press, 1952, ad 21, 1-5, D. PAGE, Sappho and Alcaeus. An Introduction to the Study of Ancient Lesbian Poetry, Oxford, Clarendon Press, 1955, 314, W. SCHMID/O STÄHLIN, Geschichte der griechischen Literatur. 1. Teil. Die Klassische Periode der griechischen Literatur. 4 Die griechische Literatur zur Zeit der attischen Hegemonie nach dem Eingreifen der Sophistik, München, Beck, 1956, 378ss., H. J. NEWIGER, Metapher und Allegorie. Studien zu Aristophanes, München, Beck, 1957, 155-164, W. B. STANFORD (ed.), Aristophanes The Frogs, London, Macmillan \& Co, 1958, ad 1427-29, 1465, T. GOULD, Platonic Love, N. Y., The Free Press of Glencoe, 1963, 44s., R. VISCHER, Das einfache Leben: wortund motivgeschichtliche Untersuchungen zu einem Wertbegriff der antiken Literatur, Göttingen, Vandenhoeck \& Ruprecht, 1965, 30s., 57s., R. CANTARELLA, Aristoph., Plut. 422-425 e le riprese eschilee, Accademia Nazionale dei Lincei Rendiconti della

to the End of the 5th century B. C., Amsterdam, Hakkert, 1969, 70s., R. E. DOYLE, ö $\lambda \beta \circ \varsigma$,

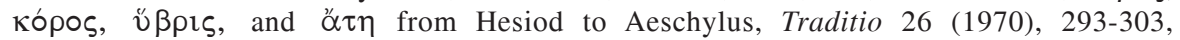
J. KAMBITSIS, L'Antiope d'Euripide. Athènes, 1972, 54s., M. C. McDONALD, Terms for Happiness in Euripides, Göttingen, Vandenhoeck \& Ruprecht, 1978, 297, 304s., W. G. THALMAnN, Xerxes' Rags: Some Problems in Aeschylus' Persians, The American Journal of Philology, 101 (1980), 260-282, A. DUPLOUY, L'utilisation de la figure de Crésus dans l'idéologie aristocratique athénienne. Solon Alcméon, Miltiade et le dernier roi de Lydie, L'Antiquité classique 68 (1999), 1-22, L. BELLONI, L'aion di due sovrani secondo Bacchilide: Creso e Ierone nel terzo epinicio, in: IDEM (ed.), Dalla lirica al teatro: nel ricordo di Mario Untersteiner. Atti del Convegno internazionale di studio, Trento-Rovereto, febbraio 1999, Trento, Dipartimento di scienze filologiche e storiche, Università degli studi di Trento, 1999, 47-58, S. COIN-LONGERAY, La richesse mortelle: l' «Agamemnon» d'Eschyle: étude d'un emploi particulier de la famille de ploutos, L'Antiquité classique 70 (2001), 27-34. 
Classe di Scienze morali, storiche e filologiche 20 (1965), 363-381, E. W. HANDLEY (ed.), The Dyskolos of Menander, Cambridge Mass., Harvard University Press, 1965, ad 208ss., H. BUCHNER, Eros und Sein, op. cit., 83ss., G. THOMPSON (ed.), The Oresteia of Aeschylus. vol. II, $2^{\mathrm{a}}$ ed. rev. e aum., Amsterdam/ Prague, Hakkert/Academia, 1966, ad Agam. 218-21, H. D. F. KITTO, Poiesis. Structure and Thought, Berkeley/L.A., University of Carolina Press, 1966, 110, B. A. van GRONINGEN, Theognis. Le livre premier, édité avec un commentaire, Amsterdam, Noord-Hollandsche Uitgevers Maatschappij, 1966, 56, 62s., 76, 141, 152, 155, 246, 257, H.-O. WEBER, Die Bedeutung und Bewertung der Pleonexie von Homer bis Isokrates, Diss. Bonn, 1967, 16s., A. A. LONG, Language and Thought in Sophocles. A Sudy of Abstract Nouns and Poetic Technique, London, Athlone Press, 1968, 138, 140, H. FLASHAR (ed.), Aristoteles Problemata physica, Darmstadt, Wissenschaftliche Buchgesellschaft, 1983³, 704s., H. -J. CLASSEN, Sprachliche Deutung als Triebkraft platonischen und sokratischen Philosophierens, München, Beck, 1959, 130s., F. HEINIMANN, Nomos und Physis. Herkunft und Bedeutung einer Antithese im griechischen Denken des 5. Jahrhunderts, Basel, Reinhardt, 1945, reed. Darmstadt, Wissenschaftliche Buchgesellschaft, 1987, 31ss., 34, 36, R. B. ONIANS, The Origins of European Thought. New Interpretations of Greek, Roman and Kindred Evidence about Some Basic Jewish and Christian Beliefs, Cambridge, University Press, 1951, 222-223, 405, M. FINLEY, The Ancient Economy, Berkeley, University of California Press, 1973, London, Penguin, 1992, 41, K. J. DOVER, Greek Popular Morality in the Time of Plato and Aristotle. Oxford, Blackwell, 1974, 91, 109ss., O. LANGWITZ SMITH, Poverty in Theognis, Museum Tusculanum 24 (1974), 23-33, C. COLLARD (ed.), Euripides Supplices, vol. II Commentary, Groningen, Bouma, 1975, ad 176-9, 241b3, A. FUKS, The Conditions of Riches $(\pi \lambda \circ \hat{v} \tau \circ \varsigma)$ and of Poverty $\left(\pi \varepsilon v^{\prime} \alpha\right)$ in Plato's Republic, Rivista storica dell' Antichità 6-7 (1976-1977), 63-73, A. FUKS, Plato and the Social Question. The Problem of Poverty and Riches in the Republic, Ancient Society 8 (1977), 49-83, M. L. WEST (ed.), Hesiod Works and Days, Oxford, Clarendon Press, 1978, ad 496s., 717, J. M. BELL, Simonides in the Anecdotal Tradition, Quaderni Urbinati di Cultura Classica 28 (1978), 29-86, em especial 48ss., F. HEBERLEIN, Plythygieia. Zur Gegenwelt bei Aristophanes, Frankfurt a. M., Haag+Herchen, 1980, 164, 170ss., D. A. CAMPBELL, The Golden Lyre. The Themes of the Greek Lyric Poets, London, Duckworth, 1983, 90, 111, 192, 223, 226s., 230, R. P. MARTIN, Healing Sacrifice Battle. Amechania and Related Concepts in Early Greek Poetry, Innsbruck, Institut für Sprachwissenschaft der Universität Innsbruck, 1983, 57s.,101s., E. M. de STE. CROIX, The Class Struggle in the Ancient Greek World From the Archaic Age to the Arab Conquests, London, Duckworth, 1983, 53, E. DAVID, Aristophanes and Athenian Society of the Early Fourth Century B.C., Leiden, Brill, 1984, 5ss., A. H. SOMMERSTEIN, Aristophanes and the Demon Poverty, The Classical Quarterly 34 (1984), 314-333, A. HARDER, Euripides' Kresphontes and Archelaos, Leiden, Brill, 1985, ad fr. 203, 248, pp. 210s., 240s., M. M. MARKLE, Jury Pay and Assembly Pay at Athens, History of Political Thought, 6 (1985), 265-297, reed. In: P. J. RHODES (ed.), Athenian Democracy, Edinburgh, Edinburgh University Press, 2004,

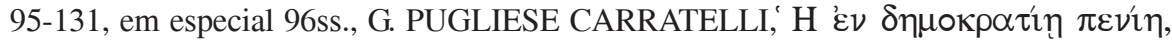


La parola del passato 40 (1985), 426-430, V. COBB-STEVENS, Opposites, Reversals, and Ambiguities: The Unsettled World of Theognis, in: T. J. FIGUEIRA/ G. NAGY (ed.), Theognis of Megara. Poetry and the Polis,Baltimore/London, The Johns Hopkins University Press, 1985, 159-175, em especial 161ss., R. G. USSHER (ed.), Aristophanes Ecclesiazusae, New Rochelle, Caratzas, 1986, ad 604s., U. GALIMBERTI, Gli equivoci dell'anima, Milano, Feltrinelli, 1987, 2003², 229s., S. GRAEFE, Der gespaltene Eros - Platons Trieb zur Weisheit, Frankfurt a. M., Lang, 1989, 123ss., D. ARNOULD, Ploutos et pénia dans la poésie lyrique, élégiaque et iambique archaïque, in: M. WORONOFF (ed.), L'univers épique. Rencontres avec l'Antiquité classique,Vol. II., Paris, Les Belles Lettres, 1992, 157-171, B. MARZULLO, I sofismi di Prometeo, Firenze, La Nuova Italia, 1993, 228ss., 501, A. WINTERLING, „Arme” und „Reiche”. Die Struktur der griechischen Polisgesellschaften in Aristoteles' ,Politik', Saeculum 44 (1993), 179-205, J. ROMILLY, Tragédies grecques au fil des ans, Paris, Belles Lettres, 1995, 201s., U. CURI, Endiadi. Figure della duplicità, Milano, Feltrinelli, 1995, 9, 57ss., 117, 145s., N. DUNBAR (ed.), Aristophanes Birds, Oxford, Clarendon Press, 1995, ad 604s., M. D. RICHMOND, Isocrates' Panegyricus and the Argument of Poverty and War, Diss., University of Louisville (Ky.) 1995, E. LÉVY, Richesse et pauvreté dans le «Ploutos», Ktèma 22 (1997), 201-212, K. SIER, Die Rede der Diotima, op. cit., 50ss., J. F. McGLEW, After Irony: Aristophanes' Wealth and its Modern Interpreters, American Journal of Philology 118 (1997), 35-53, em especial 39ss., K. DOVER (ed.), Aristophanes Frogs, Oxford, University Press, 1997, ad 1463-5, B. HUSS, Xenophons Symposion. Ein Kommentar, Stuttgart/Leipzig, Teubner, 1999, 194, 257, 273, R. THOMAS, Herodotus in Context. Ethnography, Science and the Arty of Persuasion, Cambridge, Cambridge University Press, 2000, 109ss., S. COIN-

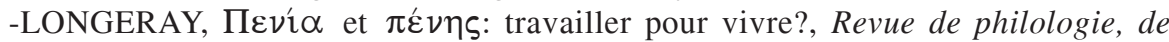
littérature et d'histoire anciennes $3^{\text {a }}$. sér. 75 (2001), 249-256, A. H. SOMMERSTEIN (ed.), The Comedies of Aristophanes, vol. 11 Wealth, Warminster, Aris \& Phillips, 2001, 4s, 19, ad 437, 510-6, 548, 549, M. S. MARSILIO, Hesiod and Theognis on Poverty, The Classical Bulletin 78 (2002), 131-152, P. A. CABALLERO (ed.), Penia: los intelectuales de la Grecia clásica ante el problema de la pobreza, Buenos Aires, Universidad de Buenos Aires, Instituto de Filología Clásica, 2003, C. COLLARD, M. J. CROPP/G. GIBERT (ed.), Euripides Selected Fragmentary Plays, vol. II, Oxford, Aris \& Phillips, 2004, ad Archelaus 230 (p. 354), 248 (p. 358), M. P. NICHOLS, Socrates' Contest with the Poets in Plato's Symposium, Political Theory 32 (2004), 186-206, F. C. C. SHEFFIELD, Plato's Symposium. The Ethics of Desire, Oxford, Oxford University Press, 2006, 42ss., W. D. DESMOND, The Greek Praise of Poverty. Origins of Ancient Cynicism, Notre Dame (In), University of Notre Dame Press, 2006, F. CONTI BIZZARRO, Gli insetti di Penia, Vichiana $4^{\text {a }}$ S. 8 (2006), 11-34.

Para uma análise mais cuidada do sentido de 'óлopí $\alpha$, cf. C. J. BLOMFIELD (ed.), Aschylus Prometheus Vinctus, Canterbury, J. Smith, 1810, ad 59, C. E. GRAVES, The Fourth Book of Thucydides, London, Macmillan. 1884, 1888², reed.: Bristol, Bristol Classical Press, 1982, ad IV, xxxii, M. HEIDEGGER, Platon: 
Sophistes (WS 1924/25, Gesamtausgabe 19), Frankfurt a. M., Klostermann, 1992, 126s., O. BECKER, Das Bild des Weges und verwandte Vorstellungen im frühgriechischen Denken, Berlin, Weidmann, 1937, 77, 120-121, 124-125, 154, 156, 165s., 168, 172, 199s., 201, J. ORTEGA Y GASSET, Historia como sistema, Madrid, Revista de Occidente, 1941, 1975³, 131s., IDEM, La idea de principio en Leibniz y la evolución de la teoría deductiva, Madrid, Revista de Occidente, 1958, 1967, 149ss., J.-G. HANSEN, Bildhafte Sprache des Aischylos. See und Schiffahrt in metaphorischer Verwendung, Diss. Kiel, 1955, 78ss., B. WALDENFELS, Das Sokratische Fragen. Aporie, Elenchos, Anamnesis, Meisenheim a. G., A. Hain, 1961, 14ss., R. DRIESCH, Platons Wegbilder. Untersuchungen zur Funktion der Wegbilder und -metaphern im Aufbau der Dialoge Platons, Diss. Köln 1967, 8, 23s., 44s., 50, 53-54, B. WALDENFELS, Das Sokratische Fragen, op. cit., 13s., P. HUART, Le vocabulaire de l'analyse psychologique dans l'oeuvre de Thucydide, Paris, Klincksieck, 1968, 146, 203, 232, 305, M. DETIENNE/J-.P. VERNANT, Les ruses de l'intelligence. La mètis des Grecs, Paris, Flammarion, 1974, 25, 110-111, 141142, 165, 211s., H.-J. CLASSEN, Sprachliche Deutung als Triebkraft platonischen und sokratischen Philosophierens, op. cit., 130-131, G. W. BOND (ed.), Euripides Heracles, Oxford, Clarendon Press, 1981, ad 54, 105s., S. KOFMAN, Comment s'en sortir?, Paris, Galilée, 1983, 18, S. KOFMAN, Beyond aporia?, in: A. BENJAMIN (ed.), Post-structuralist Classics. London, Routledge, 1988, 7-44, em especial 25ss., W. G. ARNOTT (ed.) Alexis: The Fragments. A Commentary, Cambridge, Cambridge University Press, 1996, ad 236 (234K), 5-6, P. PAYEN, Les îles nomades. Conquérir et résister dans l'Enquête d'Hérodote, Paris, École des Hautes Études en Sciences Sociales, 1997, 297ss., O. POLTERA, Le language de Simonide. Étude sur la tradition poétique et son renouvellement, Bern, Lang, 1997, 326s., E. MESSIMERI, Wege-Bilder im altgriechischen Denken und ihre logisch-philosophische Relevanz, Würzburg, Königshausen \& Neumann, 2001, 58s., 60ss., J. AGUIRRE, La «aporía» en Aristóteles: análisis del término y exposición de las «aporías» de Metafísica III, Bitarte 11 (2004), 107-126.

Para uma análise mais cuidada de $\alpha \mu \eta \chi \alpha \nu i ́ \alpha$ e da experiência grega das situações desse tipo, veja-se designadamente W. SCHROETER, De Simonidis Cei Melici Sermone quaestiones, Leipzig, Noske, 1906, 32, F. M. CORNFORD, Thucydides Mythistoricus, London, Arnold, 1907, 223s., B. SNELL, Sapphos Gedicht

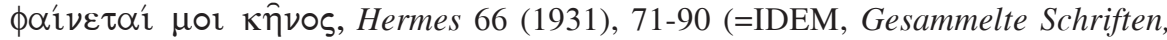
Göttingen, Vandenhoeck \& Ruprecht, 1966, 82-97), R. PFEIFFER, Gottheit und Individuum in der frühgriechischen Lyrik, in: IDEM, Ausgewählte Schriften. Aufsätze und Vorträge zur griechischen Dichtung und zum Humanismus, München, Beck, 1960, 42-54, H. FRÄNKEL, Wege und Formen frühgriechischen Denkens. Literarische und philosophiegeschichtliche Studien, ed. F. Tietze, München, Beck, 1968, 28-30, H. LLOYD-JONES, The Justice of Zeus, Berkeley-L.A./London, University of California Press, 1971, 36ss., B. SNELL, Die Entdeckung des Geistes. Studien zur Entstehung des europäischen Denkens bei den Griechen, Göttingen, Vandenhoeck \& Ruprecht, 1975, 72ss., R. P. MARTIN, Healing Sacrifice Battle, op. cit., 9s., 40-41, 43ss., 57-58s., 85, 101s., W. SCHADEWALDT, Die frühgriechische 
Lyrik (Tübinger Vorlesungen III), Frankfurt a. M., Suhrkamp, 1989, 122s., 130, W. SCHÜTZ, Astheneia physeos, Diss. Heidelberg, 1964, 111, 152, 160, M. TREU, Von Homer zur Lyrik, Wandlungen des griechischen Weltbildes im Spiegel der Sprache, München, Beck, 1955, 197s., 240, D. BREMER, Licht und Dunkel in der frühgriechischen Dichtung. Interpretationen zur Vorgeschichte der Lichtmetaphysik, Bonn, Bouvier, 1976 (Archiv für Begriffsgeschichte - Supplementheft 1), 246, 279280, 333ss., D. SANSONE, Aeschylean Metaphors for Intellectual Activity, Wiesbaden, Steiner, 1975, 67ss., E. A. SCHMIDT, Archilochos, Kallimachos, Horaz. Jambischer Geist in drei Epochen, Wiener Humanistische Blätter 20 (1978), 1-17, C. CAREY, A Commentary on Five Odes of Pindar: Pythian 2, Pythian 9, Nemean 1, Nemean 7, Isthmian 8, N.Y., Arno Press, 1981, 43, D. CONRAD, The Concept of Amekhania in Homer and Archaic Greek Poets Before Pindar, Diss. McGill University, 1982, H. LLOYD-JONES, Greek Epic, Lyric, and Tragedy. The Academic Papers of Sir Hugh Lloyd-Jones, Oxford, Clarendon Press, 1990, B. MARZULLO, I sofismi di Prometeo, Firenze, La Nuova Italia, 1993, 224ss., U. CURI, Endiadi. Figure della duplicità, Milano, Feltrinelli, 1995, 16, O. POLTERA, Le language de Simonide. Étude sur la tradition poétique et son renouvellement, Bern, Lang, 1997, 342, M. THEUNISSEN, Pindar. Menschenlos und Wende der Zeit, München, Beck, 2000, 84ss., 186ss., 203, 279, 299, 302s., U. THEIN, Le lien intratable Erquête sur le Temps dan la Republique et le Tinée, Paris, Vrin, 2001, 132ss., 148ss. G. F. HELD, Archilochos' amekhania: Pindar, Pythian 2.52-56 and Isthmian 4.1-3, Eranos 101 (2003), 30-48.

Importa, finalmente, referir um aspecto que é de grande importância, porque tem que ver com o fulcro da interpretação que aqui propomos do sentido em que o discurso de Sócrates/Diotima fala de um cruzamento entre $\pi \varepsilon v i ́ \alpha$ e $\pi$ ópos.

Em primeiro lugar, uma grande parte dos autores que se têm debruçado sobre o problema (e também uma grande parte daqueles que têm analisado o sentido de $\pi \varepsilon ́ v \eta \varsigma, \pi \varepsilon v^{\prime} \alpha$, etc.) pôs em relevo que $\pi \varepsilon v^{\prime} \alpha$ não significa necessariamente a completa falta de recursos, a absoluta indigência, escassez ou penúria, mas sim qualquer coisa como um estado de pobreza (que obriga a trabalhar $-\pi \dot{\varepsilon} v \varepsilon \sigma \theta \alpha$,

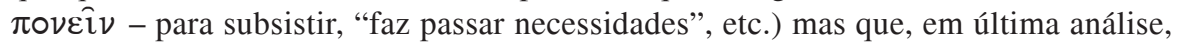
até é compatível com a posse de alguma propriedade, etc. Por outras palavras, o termo " $\pi \varepsilon \nu i ́ \alpha "$ não tem forçosamente um significado extremo, antes consigna qualquer coisa como aquilo que é descrito pela própria Пeví $\alpha$ personificada, no Plutus de Aristófanes,

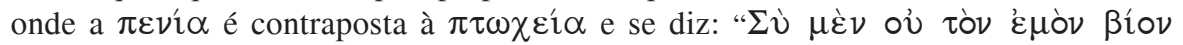

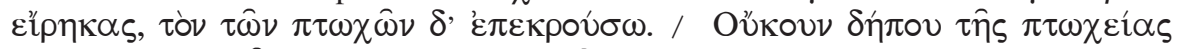

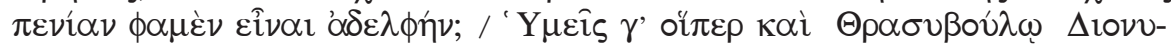

114 ARISTÓFANES, Plutus, 548ss. Veja-se, por exemplo, também PLATÃO, Respublica $618 \mathrm{a}$, onde parece nítida qualquer coisa como uma gradação $\pi \varepsilon v i ́ \alpha / \pi \tau \omega \chi \varepsilon \dot{\alpha} \alpha$ (ou ainda EURÍPIDES, Supplices, 238-245, ARISTÓTELES, Politica, 1295). Veja-se igualmente AMÓNIO GRAMÁTICO, Ammonii qui dicitur liber de differentia adfinium vocabulorum, ed.

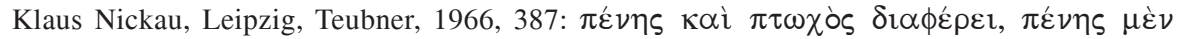

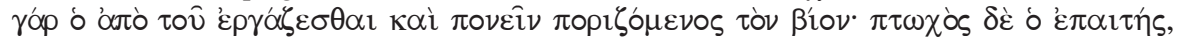

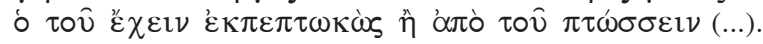




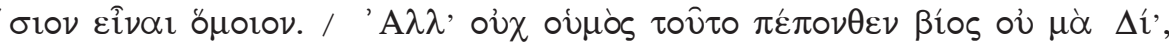

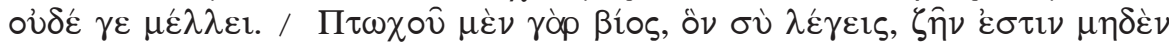

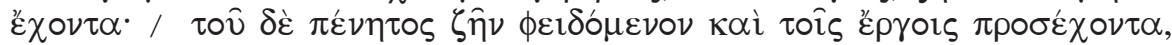

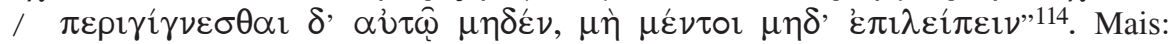
não só acontece que " $\pi \varepsilon v i ́ \alpha$ " não significa necessariamente a privação total, mas, segundo os autores em causa, na maior parte dos textos o significado do termo é, no essencial, congruente com aquilo que Aristófanes põe na boca da própria Пعví $\alpha$, quando esta fala de qualquer coisa como um estádio intermédio entre a riqueza e a absoluta privação $(\pi \tau \omega \chi \varepsilon \hat{\imath} \alpha)$ - de tal modo que não se trata de uma distinção apologética, inventada pela própria, pro domo sua ${ }^{115}$, mas, na verdade, do uso mais corrente do termo. Não cabe aqui discutir todos estes aspectos, analisar as diferentes passagens, etc. Mas importa pôr em relevo o seguinte. Por um lado, é verdade que $\pi \varepsilon v^{\prime} \alpha$ não equivale, sem mais, à indigência total, à completa falta de recursos, etc. Mas, por outro lado, também não é verdade que signifique apenas qualquer coisa como um estado intermédio entre a riqueza e a absoluta privação ou falta de recursos Pois também pode significar justamente esta última. Para não irmos mais longe, veja-se, por exemplo, o que encontramos em Respublica 421d, onde são contrapostos, por assim dizer, dois princípios, $\pi \lambda \circ \hat{\tau} \tau \circ \varsigma$ e $\pi \varepsilon v i ́ \alpha$, e se analisa o que acontece quando aqueles que se encontram no referido estádio intermédio (os que têm de trabalhar para viver, etc.) são sujeitos ao efeito de um e do outro princípio. Segundo a Respublica, o efeito da $\pi \varepsilon v i ́ \alpha$ sobre os que trabalham é desapossá-los dos próprios instrumentos de trabalho, com as consequências que daí decorrem no que diz respeito à perda de qualidade do trabalho, etc. ${ }^{116}$ Ora, não é muito difícil perceber que neste caso $\pi \varepsilon v^{\prime} \alpha$ não significa um estado intermédio, uma $\mu \varepsilon \mu \varepsilon \tau \rho \eta \mu \varepsilon v \eta$ $\varepsilon ้ \nu \delta \varepsilon 1 \alpha .{ }^{117}$ Tampouco é difícil perceber o que está por detrás de tudo isto. Tal como sucede com a maior parte dos termos, também o grego $\pi \varepsilon v^{\prime} \alpha$ consigna um campo semântico complexo - no caso, associado à ideia global de pobreza, de falta de recursos, etc. Dentro desse campo semântico, há como que um continuum de gradações, de tal modo que o termo é passível de diferentes acentuações, consoante os casos e os contextos. Em suma, a palavra $\pi \varepsilon v i ́ \alpha$ não tem um campo de significados talhado more geometrico e muito menos um campo de significados que deixe sempre de fora a ideia de total privação de recursos, da indigência absoluta, etc. Nesse aspecto, " $\pi \varepsilon v i ́ \alpha$ " é bastante parecida com a nossa palavra "pobreza": não

115 Nem tampouco do resultado de qualquer coisa como um furor distinguendi, ao modo dos Sofistas e, em especial, de Pródico e da tradição a que deu origem.

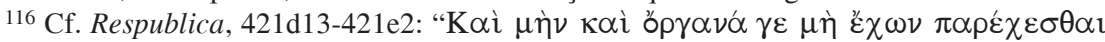

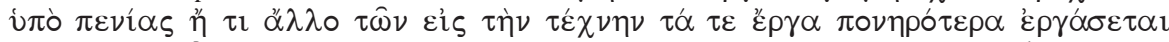

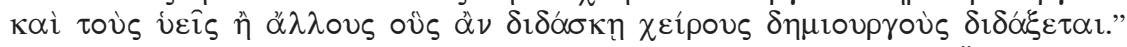

117 Como diz o escoliasta, ao glosar as palavras de Пદví $\alpha$. V/ F. DÜBNER, Scholia Graeca in Aristophanem, Paris, Didot, 1877, reed. Hildesheim, Olms, 1969, Scholia in Plutum,

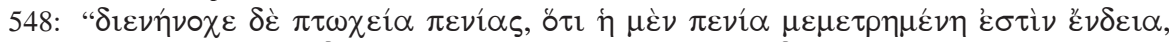

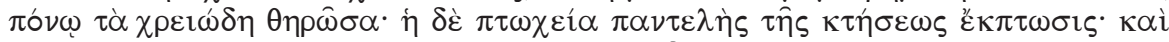

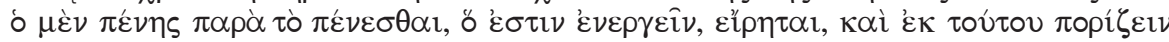

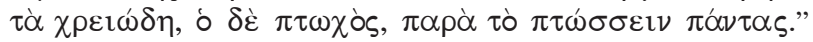


significa forçosamente a indigência, a total falta de recursos mas também pode ser usada para a expressar - e isto de tal forma que a absoluta falta de recursos (a penúria, etc.) constitui, por assim dizer, a forma mais acabada (a forma mais pobre, mais pura) de pobreza: aquela que mais corresponde à própria ideia nuclear de todo o campo semântico em causa: a ideia de falta, etc. O que, por outro lado, explica que, quando $\pi \varepsilon v i ́ \alpha$ é convertida em qualquer coisa como um princípio, contraposto a um princípio contrário (que é o que acontece em Respublica 421 e também no discurso de Sócrates/Diotima), o sentido possa e tenda a ser aquele que corresponde às formas extremas - ou seja, o sentido correspondente a uma $\pi \varepsilon \nu i ́ \alpha$ que nada tem

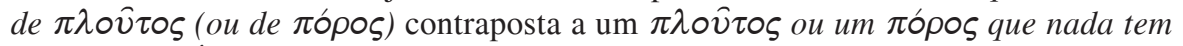
de $\pi \varepsilon \nu i ́ \alpha$. É claro que onde, como no discurso de Sócrates/Diotima, os dois princípios se cruzam, se contrariam, etc., e exercem conjuntamente o seu efeito sobre "principiados", há qualquer coisa como uma mistura e conjugação dos opostos. Mas a mistura ou combinação tem lugar nos principiados (que são justamente intermédios, têm um carácter correspondente a qualquer coisa como $\pi \lambda \circ \hat{\tau} \tau \circ \varsigma \mathrm{x}$ $\pi \varepsilon v^{\prime} \alpha$ ou $\pi \delta$ ó x $\left.\pi \varepsilon v i ́ \alpha\right)$. A mistura não tem lugar na constituição de cada um dos princípios, que são concebidos justamente como condições de possibilidade da própria combinação sc. de todos os estados intermédios ou de todas as condições intermédias. Neste sentido, no discurso de Sócrates/Diotima não se fala do cruzamento entre $\pi$ ópos e a $\pi \varepsilon v i ́ \alpha$ concebida como estado intermédio, mas sim do cruzamento entre dois princípios antagónicos e extremos, tal como em Respublica 421d.

Mas, sendo assim, acontece que também uma grande parte dos autores que

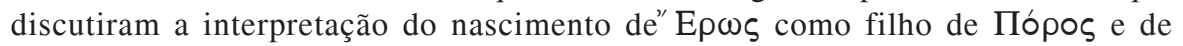

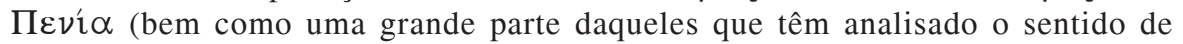
$\pi$ $\rho \rho \varsigma$ e termos afins) pôs em relevo que $\pi$ ópos não significa propriamente a pura posse (a riqueza, afluência, etc.), mas sim o meio de conquistá-la (o ter via, ter "saída", ter acesso, a capacidade de obter, o recurso, o expediente - não, portanto, a situação em que algo já está adquirido, mas o meio ou a passagem que dá acesso à sua aquisição). Na interpretação do Symposium, a insistência neste aspecto remonta pelo menos a E. ZELLER, Die Philosophie der Griechen in ihrer geschichtlichen Entwicklung dargestellt, 2. Theil. 1. Abtheilung, Sokrates und die Sokratiker. Plato und die alte Akademie, Leipzig, Fues, 1875³, 513. Ora, também aqui há que ter em atenção um conjunto de aspectos semelhantes àqueles que acabamos de referir a respeito de $\pi \varepsilon v i \alpha$. Por um lado, é claro que, em muitos casos, $\pi \delta$ pos e os termos afins têm que ver justamente com o meio (com a possibilidade de ir, de chegar, de obter) e não com o estar-já-na-posse (com o estado em que já se está ido, já se chegou, já se obteve, etc.). Mas também aqui é preciso ver que se trata de um campo semântico complexo, com um contínuo de gradações, e constituído de tal modo que mesmo aqueles sentidos que acentuam o meio, o recurso, o expediente - a via, a passagem, a obtenção ou a aquisição - acabam por estar como que dirigidos à ideia de posse, sem a qual não teriam sentido e em torno da qual, por assim dizer, orbitam. Assim, o campo semântico de $\pi \delta ́$ pos está sempre em relação central com a ideia de posse - e, dessa forma, inclui-a. Mas mais. Se o campo semântico de $\pi \delta ́$ po̧ tem estas 
características, a posse, a plena posse, enquanto tal (quer dizer, a posse não restringida por nada de oposto que lhe resista ou que a diminua) constitui, por assim dizer, a forma mais acabada de $\pi \delta$ oo - a forma mais pura e plena disso: aquela que mais corresponde à própria ideia nuclear de todo o campo semântico em causa: a ideia de alcance, de desimpedimento, de domínio, de não-restrição (de ausência de obstáculos, de "paredes", que retenham, prendam, impeçam), etc. ${ }^{118} \mathrm{O}$ que, por outro lado, explica que, quando $\pi \delta \rho \circ \varsigma$ é convertido em qualquer coisa como um princípio, contraposto a um princípio contrário, (que é o que acontece no discurso de Sócrates/Diotima, onde $\pi$ ópos assume as funções que na Respublica $421 \mathrm{~d}$ cabem a $\pi \lambda \circ \hat{v} \tau \circ \varsigma$ ), o sentido em causa possa e tenda a ser aquele que corresponde às formas extremas - ou seja, o sentido correspondente a um $\pi$ ópos que nada tem de $\pi \varepsilon \nu i ́ \alpha$, contraposto a uma $\pi \varepsilon \nu i ́ \alpha$ que nada tem de $\pi$ ópos. E aqui vale de novo o que há pouco dissemos sobre o carácter "puro" dos próprios princípios que constituem a condição de possibilidade da combinação ou da mistura - ou seja, sobre o facto de o cruzamento só ocorrer nos principiados e não na própria constituição dos princípios de que aqueles dependem.

Em suma, ao pôr em contraste $\pi \varepsilon v i ́ \alpha$ e $\pi$ ópos (ao insistir, como claramente faz, na sua oposição e ao constituí-los em princípios da natureza mista ou combinada de

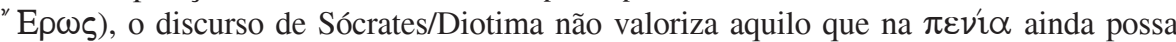
haver de diferente da absoluta privação (i.e. aquilo que a $\pi \varepsilon v i ́ \alpha$ relativa - a $\pi \varepsilon v i ́ \alpha$ enquanto oposta à $\pi \tau \omega \chi \varepsilon \dot{\imath} \alpha$ - já contém de $\pi \delta$ ós) ou aquilo que em $\pi \delta$ ó possa haver de estar-aquém ou retenção (ou seja, aquilo que o $\pi$ ópos, enquanto mero a-caminho, ainda contém de $\pi \varepsilon v^{\prime}(\alpha)$. Não. A tendência vai em direcção aos extremos: à pura $\pi \varepsilon \nu i ́ \alpha$ e ao puro $\pi \delta ́ p o \varsigma$. E a realidade intermédia que o discurso faz corresponder a "̌p $\omega_{\zeta}$ não é algo de intermédio entre instâncias elas mesmas já intermédias. Ou seja,

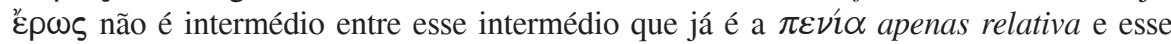
intermédio que também já é o $\pi$ ópos enquanto mero a-caminho. Por outras palavras,

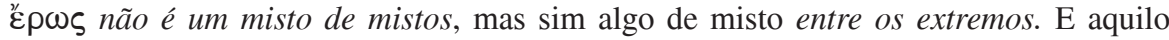
que os comentadores em causa atribuem aos progenitores, quando insistem em que se

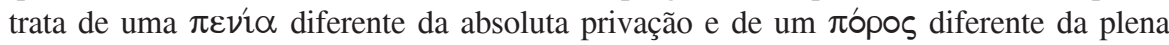
posse, não é verdade em relação aos progenitores - só é verdade em relação ao filho,

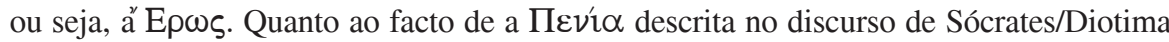
afinal não ser assim tão falha de recursos ou de expediente, pois é ela quem toma a iniciativa, "assume o comando das operações" e monta a cilada a $\pi$ ópo - esse é um traço típico de incongruência cómica em que o discurso de Sócrates/Diotima assume o seu parentesco com o discurso de Aristófanes e mostra com toda a nitidez os traços que, na verdade, também tem - de paródia (e, designadamente, de paródia da comédia, das "etiologias" cómicas, etc.)."119

118 Veja-se, por exemplo, J. WIPPERN, Eros und Unsterblichkeit in der Diotima-Rede des Symposions, in: H. FLASSHAR/ K. GAISER (ed.), Synusia. Festgabe für W. Schadewaldt zum 15. März 1965, Pfullingen, Neske, 1965, 123-159, p. 146, nota 27.

119 Sobre a incongruência cómica, veja-se, por exemplo, C. C. JERNIGAN, Incongruity in Aristophanes, Menasha (Wis.), George Banta Publishing Co., 1939, W. SÜSS, Scheinbare 
und wirkliche Inkongruenzen in den Dramen des Aristophanes, Rheinisches Museum 97 (1954), 115-159, 229-254, 289-316, O. SEEL, Aristophanes oder Versuch über die Komödie, Stuttgart, Klett, 1960, 43ss., M. HEATH, Political Comedy in Aristophanes, Göttingen, Vandenhoeck \& Ruprecht, 1987. A questão tem que ver com as relações entre o discurso de Sócrates/Diotima e o discurso de Aristófanes (e também entre o próprio Symposium e a comédia ou entre o discurso filosófico e as etiologias míticas), etc. Mas, só para se ter uma noção da rede de alusões e "correspondências" que há entre as palavras de Sócrates/Diotima e a comédia,

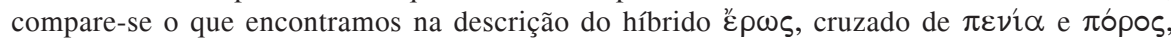
com a descrição de híbridos na comédia de Aristófanes, em particular a descrição do próprio Agatão como híbrido de homem e mulher (Thesmophoriazusae, vv. 130ss.) e a descrição do híbrido de homem e de ave (Aves 166-170), que tão expressivamente aponta o carácter fugidio de tais híbridos (ou, como Platão diria - cf. Respublica $479 \mathrm{c} 4$ - a forma como se furtam a

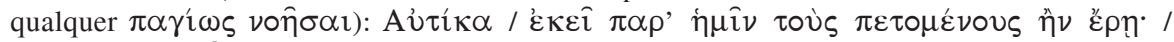

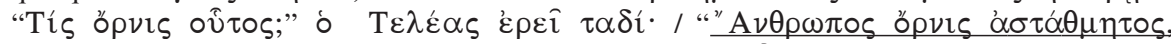

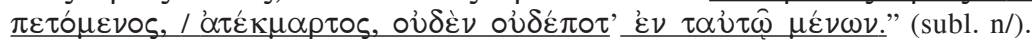

Uma palavra de agradecimento à Prof. Dr. ${ }^{a}$ Marta Mendonça e ao Dr. Paulo Lima pelo cuidado com que reviram o texto. 